Universidade de São Paulo

Instituto de Física de São Carlos

Maurício Falvo

Método de mapeamento espaço-espectral em imagens multi-espectrais e sua aplicação em tecidos vegetais 

Maurício Falvo

\section{Método de mapeamento espaço-espectral em imagens multi-espectrais e sua aplicação em tecidos vegetais}

Tese apresentada ao Programa de PósGraduação em Física do Instituto de Física de São Carlos da Universidade de São Paulo, para obtenção do título de Doutor em Ciências.

Área de Concentração: Física Aplicada:

Opção: Física Computacional

Orientador: Prof. Dr. Odemir Martinez Bruno

Versão Corrigida

(versão original disponível na Unidade que aloja o Programa)

São Carlos 


\section{AUTORIZO A REPRODUÇÃO E DIVULGAÇÃO TOTAL OU PARCIAL DESTE TRABALHO, POR QUALQUER MEIO CONVENCIONAL OU ELETRÔNICO PARA FINS DE ESTUDO E PESQUISA, DESDE QUE CITADA A FONTE.}

Ficha catalográfica revisada pelo Serviço de Biblioteca e Informação do IFSC, com os dados fornecidos pelo(a) autor(a)

\section{Falvo, Mauricio}

Método de mapeamento espaço-espectral em imagens multi-espectrais e sua aplicação em tecidos vegetais / Mauricio Falvo; orientador Odemir Martinez Bruno versão corrigida -- São Carlos, 2015.

$153 \mathrm{p}$.

Tese (Doutorado - Programa de Pós-Graduação em Fisica Computacional) -- Instituto de Fisica de São Carlos, Universidade de São Paulo, 2015.

1. Imagens multi-espectrais. 2. Microscopia confocal. 3. CLSM. 4. Fluorescência. 5. Tecido vegetal. I. Bruno, Odemir Martinez, orient. II. Titulo. 


\section{AGRADECIMENTOS}

A Deus, por mais esta oportunidade oferecida, pelas felicidades vividas e, dificuldades superadas ...

À minha querida esposa Sílvia, pelo apoio, paciência, compreensão e carinho. Aos meus filhos Carolina e Eduardo, pelo apoio, risos, e momentos importantíssimos em nossas vidas, que nos fazem valorizar o que deve ser realmente valorizado.....

Aos meus pais Vincenzo e Nair, pelo exemplo de vida e valores que me passaram e aos meus irmãos Flávio e Márcio e famílias, por saber que sempre poderemos contar um com o outro.

Aos meus sogros Erasmo e Teresinha, e cunhados Sérgio, Stela e familiares pelo incentivo constante...

Aos meus amigos Prof. Dr. Odemir Martinez Bruno (meu orientador), por mais uma vez ter confiado em mim e, ao Prof. Dr. Francisco E. G. Guimarães pela ajuda na captura das imagens e pelas conversas sobre microscopia.

À Profa. Dra. Rosana Kolb pela gentileza em produzir as lâminas dos cortes foliares.

Aos velhos e novos amigos que a vida nos faz reencontrar e encontrar(em ordem cronológica): Gisele R. Nascimento, Lia Bones, Fuad Gattaz Sobrinho, Oscar I. P. Pacheco, Cristian Bones, José Lotúmulo Jr., Roberto Ferrari Jr., Sandra Abib, Janaína R. Labadessa e a muitos outros, que agora me fogem os nomes... meu muito obrigado por tudo!

Ao pessoal da secretaria de pós-graduação - em especial à Beth, Silvio e Ricardo - sempre cordiais e prestativos no atendimento.

Ao pessoal da biblioteca, em especial à Neusa e Cristina, pela grande ajuda na formatação bibliográfica e, ao Ítalo e pessoal da gráfica e a todos os docentes e funcionários do IFSC, que de alguma forma direta ou indireta, colaboraram comigo.

E meus agradecimentos ao pessoal da CDCC e ao Prof. Dr. Dietrich Schiel (in memoriam) - responsáveis pelo meu gosto pela ciência e pelas oportunidades oferecidas. 



\section{RESUMO}

FALVO, M. Método de mapeamento espaço-espectral em imagens multi-espectrais e sua aplicação em tecidos vegetais. 2015. 153 p. Tese (Doutorado em Ciências) - Instituto de Física de São Carlos, Universidade de São Paulo, São Carlos, 2015.

Imagens multiespectrais são utilizadas em diferentes aplicações, que vão desde sensoriamento remoto a processos médicos. No caso de imagens multiespectrais oriundas de microscopia confocal de varredura à laser (Confocal Laser Scanning Microscopy-CLSM), a extração da informação se inicia pela conversão das assinaturas espectrais, em uma imagem RGB. Esta imagem é a referência para a seleção da região de interesse, da qual se obtém a assinatura espectral média, originada do arquivo multiespectral (LSM). Mesmo utilizando um padrão muito bem estabelecido de conversão, alguns pontos devem ser considerados: i) o processo de conversão reduz a informação, a uma ordem de $10^{-145 \%}$; ii) a cor é uma experiência sensorial, subjetiva e pessoal, interferindo na seleção da região de interesse e; iii) a assinatura é obtida pela média espectral, da região de interesse, selecionada manualmente.Assim, esta tese de doutorado propõem um método de mapeamento e visualização das informações de imagens multiespectrais, combinando um algoritmo de agrupamento não supervisionado(kmeans) e um algoritmo que define uma paleta de cores coerentes com a informação espectral das regiões mapeadas. Aplicou-se o método em três casos de estudos de tecidos vegetais: i) no prétratamento de paredes celulares da cana-de-açúcar; ii) na plasticidade foliar do Jacaranda caroba e; iii) no uso de assinaturas espectrais na classificação de plantas do Cerrado. Os resultados demonstraram que o método é bastante robusto, permitindo de forma inovadora a: visualização, análise e comparação de imagens multiespectrais qualitativa e quantitativamente, e que seu uso é viável em qualquer área de pesquisa que utilize imagens multiespectrais.

PALAVRAS-CHAVE: Imagens multiespectrais. Microscopia confocal. CLSM. Fluorescência. Tecido vegetal. 



\section{ABSTRACT}

FALVO, M. Spatio-spectral mapping method in multispectral images and their application in plant tissues. 2015. 153 p. Tese (Doutorado em Ciências) - Instituto de Física de São Carlos, Universidade de São Paulo, São Carlos, 2015.

Multispectral images are used in different applications, ranging from remote sensing images to medical images. In the case of multispectral images derived from confocal laser scanning microscopy (CLSM), the extraction of information begins with the conversion of spectral signatures in an RGB image. This is the reference for selecting the region of interest, from which it gets the average spectral signature, originated from multispectral file (LSM). Even using a very well established pattern of conversion, some points should be considered: i) the conversion process reduces the information on the order of $10^{-145 \%}$; ii) the color is a sensory experience, subjective and personal, interfering in the selection of the interest region and; the signature is obtained by the spectral average, from interest region which is selected manually. Thus, this doctoral thesis proposes a method of mapping and visualization of multispectral imaging information, combining an unsupervised clustering algorithm (kmeans) and an algorithm that defines a consistent color palette with the spectral information of mapped regions. The proposed method was applied in three cases plant tissue studies: i) in the pre-treating the cell walls of sugarcane; ii) in the leaf plasticity of Jacaranda caroba; iii) in the use of spectral signatures in the Cerrado plant classification. The results showed that the proposed method is quite robust. It presents innovation to the visualization and analysis of multispectral images and makes possible a qualitative and quantitative comparison of a group of multispectral images. Besides that, its use is feasible in any area of research, which are using multispectral images.

KEYWORDS: Multispectral images. Confocal microscopy. CLSM. Fluorescence. Plant tissue. 



\section{LISTA DE FIGURAS}

Figura 1.1 Imagens espectrais da parede celular de bagaço de cana e os respectivos espectros obtidos pela seleção de regiões na imagem de referência: a) fibra controle; b) fibra tratado com $\mathrm{H}_{2} \mathrm{SO}_{4}$ e; c) Fibra tratada com $\mathrm{NaOH}$ após tratamento de $\mathrm{H}_{2} \mathrm{SO}_{4} \ldots \ldots \ldots \ldots \ldots$. . . . . . . . . . . . . . . . . .

Figura 1.2 Imagens de uma parece celular vegetal: (a) parece celular obtida por microscopia confocal de varredura à laser; (b) diagrama da concentração de agregados de lignina de uma parede celular vegetal; (c) imagem após processamento pelo método desenvolvido da imagem multiespectral (a). . .

Figura 2.1 Exemplos de plantas com folhas simples Urera subpeltata [Miq.] (esq.) e folhas compostas Machaerium anguftifolium [Benth.] (dir.). . . .

Figura 2.2 Corte foliar : esq. folha dorsiventral; dir. isolateral.

Figura 2.3 Partes constituintes de um tecido foliar: ES- epiderme superior; MPmesófilo paliçádico; ME- mesófilo esponjoso; El- epiderme inferior. . . . . . .

Figura 2.4 Estômatos na superfície foliar.

Figura 2.5 Exemplos de sistemas de venação de uma monocotiledônea Schizolepis trigonocarpa $[\mathrm{Nees}](\mathrm{esq})$ e dicotiledônea Dortenia multiformis [Miq.] (dir).

Figura 2.6 Sequência de desenvolvimento do meristema foliar: (a) primórdio foliar; (b) meristema

Figura 2.7 Corte transversal mesófilo paliçádico (PT) and esponjoso (ST) do tecido foliar de R. typhina de plantas desenvolvidas em cinco diferentes intensidades luminosas : 100\% (CK), 50\% (T1), 25\% (T2), 10\% (T3) and $5 \%$ (T4). Barra de referência $1 b a r=50 \mu m$. Obs: Medidas do mesófilo esponjoso(em vermelho) foram realizadas pelo autor deste trabalho. . . . . 
Figura 2.8 Cortes P. suberosa (d) folha de sombra, (e) folha de sol, (f) folha de sol evidenciando a presença de antocianinas. Medidas realizadas em unidades de pontos(pt) com reescala das barras de (e) e (f) tendo como referência a barra de $(\mathrm{d}) \ldots \ldots \ldots \ldots$. . . . . . . . . . . . . . . . . . . . . . . . . . .

Figura 3.1 Diagrama de Jablonski, ilustrando a absorção, conversão interna de energia, emissão por fluorescência e emissão por fosforescência. . . . . . . . p. p. 41

Figura 3.2 Sobreposição espectral; espectro de absorção traço contínuo; espectro pontilhado espectro de emissão. . . . . . . . . . . . . . . . . . . . . .

Figura 3.3 Diagrama esquemático de um microscópio confocal por fluorescência:

(a) controle posicionamento; (b)pin hole fonte; (c) amostra; (d) objetiva;

(e) espelho dicróico; (f) filtro; (g) pin hole do detetor; (h)fotomultiplicadora.

Figura 3.4 Esquerda: unidade de varredura $X Y$ : (1) feixe laser; (2) espelho de varredura em X; (3) espelho de varredura em Y. Direira: movimento de varredura do feixe de laser passando pela objetiva: (1) feixe laser; (2) amostra. p. 44

Figura 3.5 Esquerda: diagrama de uma fotomultiplicadora de um canal. Direita: fotomultiplicadora linear de 32 canais. . . . . . . . . . . . . . . . p. 44

Figura 3.6 esquerda: Ilustração do processo de varredura pontual; direita: Imagem de corte confocal de fibras vegetais.

Figura 3.7 Esquerda:Imagem multiespectral composta por 32 canais com seu respectivo comprimento de onda impresso no canto superior esquerdo. Direita: Síntese dos 32 canais da imagem anterior para sistema de cores RGB, realizado pelo software proprietário do equipamento. . . . . . . . . . . .

Figura 3.8 exemplos de: (a)representação de uma imagem multiespectral de 32 canais capturados, entre $400 \mathrm{~nm}$ a $700 \mathrm{~nm}$; (b) redução da dimensionalidade para três canais - RGB; (c) síntese da imagem apresentada no monitor. . .

Figura 4.1 Principais problemas no processamento de imagens multiespectrais.

Figura 4.2 Diagrama representando a nuvem de pixel antes da tranformada PCA (esq.) e depois da aplicação da transformada(dir). . . . . . . . . . . . . .

Figura 4.3 Curvas de sensibilidade dos cones $S, M$ e $L$ por comprimento de onda. p. 55 
Figura 4.4 Método experimental para obtenção de uma cor com base em três feixes de luzes monocromáticos. O CIE definiu uma tabela de pesos W1, W2 e W3 para uma comprimentos de onda indo de 380nm a 770nm, denominada de CIE RGB 1934. . . . . . . . . . . . . . . . . . . . . . . . .

Figura 4.5 Espectro de resposta do sistema de cores RGB (esq.) e do sistema $X Y Z$ (dir.).

Figura 4.6 Sistema de cores CIE XYZ e o plano de intensidade máxima.

Figura 4.7 Transformação linear do espaço CIE XYZ (esq.) para o espaço de coordenadas CIExy; Diagrama cromático obtido do CIExy(dir.).

Figura 4.8 Imagem em tons de cinza (esq) e seu respectivo histograma (dir).

Figura 4.9 Exemplo de imagem com o brilho alterado(dir) e seu respectivo histograma(esq). . . . . . . . . . . . . . . . . . . . . . . . . .

Figura 4.10 Exemplo de imagem com alteração de contraste (dir) e seu respectivo histograma $(\mathrm{esq}) . \ldots \ldots \ldots \ldots \ldots$

Figura 4.11 Diagrama mostrando os K vizinhos de um píxel. . . . . . . . . . . . p. p.62

Figura 4.12 Processo de convolução de um filtro sobre uma imagem. . . . . . . p. 63

Figura 4.13 Variação do parâmetro que determina a frequência(esquerda); variandose o parâmetro $t$ há variação de translação da função(centro) ; transformada wavelet aplicada em um sinal e seu respectivo resultado(direita) . . . . . . p p.66

Figura 4.14 Diagrama mostrando o processo de aplicação da transformada de Harr(esq) e; exemplo de um resultado da aplicação da transformada de Haar, em um sinal $1 \mathrm{D}$ (dir) . . . . . . . . . . . . . . . . . p. 67

Figura 4.15 Diagrama ilustrando a aplicação de uma transformada discreta wavelet.

Figura 5.1 Processo de mapeamento espectro-espacial de imagens de LSM. Diagrama com as principais etapas do processo e seus produtos.

Figura 5.2 Aquisição seguida pelo processamento numérico.

Figura 5.3 Detalhamento do processo de processamento numérico. . . . . . . p.73

Figura 5.4 Normalização espectral aplicada na matriz de imagem multiespectral. p.74

Figura 5.5 Diagrama da etapa de segmentação espectral. . . . . . . . . . . . . p. 76 
Figura 5.6 Detalhamento da etapa de segmentação espectral. . . . . . . . . . p. 77

Figura 5.7 Exemplificação de agrupamento por K-means cujos centróides no método apresentado representam o espectro médio de cada grupo. . . . . p. p.78

Figura 5.8 Diagrama das etapas de mapeamento e visualização. . . . . . . . . . p. 78

Figura 5.9 Diagrama detalhado do processo de mapeamento e visualização. . . p.79

Figura 5.10 Paleta de cores gerada para um conjunto de cinco assinaturas espectrais. Deve-se notar que há uma equidistância entre as cores, para garantir uma alta discrepância de cores. . . . . . . . . . . . . . . . . . .

Figura 5.11 Colunas: RGB - geradas pelo microscópio; RGB +Kmeans - imagens RGB com aplicação de kmeans; RGB+Método - imagens RGB processadas pelo método e; coluna LSM+Método - arquivos multiespectrais processados pelo método. As linhas de $A-E$ correspondem à células de cana-de-açúcar : (A) parede celular in natura; (B) parede celular tratada com $\mathrm{H}_{2} \mathrm{SO}_{4}$; (C) parede celular tratada com $\mathrm{NaHO} 0.5 \%$; (D) parede celular tratada com $\mathrm{NaOH} 2.0 \%$ e; (E) célula completa de fibra de cana-de-açúcar. . . . . . . .

Figura 5.12 Aplicação simultânea, do método de mapeamento espaço-espectral, em múltiplas imagens multiespectrais. . . . . . . . . . . . . . . . p.84

Figura 5.13 Etapas de geração do mapeamento espectro-espacial. . . . . . . . . p. 86

Figura 6.1 Microscópio confocal de varredura à laser do Instituto de Física de São Carlos. . . . . . . . . . . . . . . . . . . . . . . . . . p. 90

Figura 6.2 Imagens de cortes de fibras e células de cana-de-açúcar e o diagrama e das dimensões do volume ótico do ponto focal. . . . . . . . . . . . . . p. p 90

Figura 6.3 Assinaturas espectrais que podem ser encontradas em folhas. . . . p. p1

Figura 6.4 Produção de etanol de segunda geração. . . . . . . . . . . . . . . . p.92

Figura 6.5 (a) Molécula de lignina; (b) agregados de lignina e respectivos espectros; (c) celula vegetal obtida por CLSM e a mesma imagem após aplicação do método de mapeamento; (d) e, respectivos espectros mapeados (c). .

Figura 6.6 (a) modelo conhecido de segmentação da lignina na parede celular; (b) imagem obtida por software proprietário do microscópio confocal e respectivas assinaturas espectrais por região e; (c) imagem obtida pelo método de mapeamento desenvolvido, aplicado na imagem multiespectral da amostra. p. 95 
Figura 6.7 Da esquerda para a direita: imagem obtida do microscópio sem a aplicação do método; imagem com a aplicação do método; gráfico dos espectros obtidos pelo método; histograma de ocorrência de cada espectro na imagem.

Figura 6.8 (a) fibra de bagaço de cana não tratado; (b) bagaço tratado com $\mathrm{H}_{2} \mathrm{SO}_{4}$ a $1 \%$; (c) bagaço tratado com $\mathrm{NaOH}$ a $2 \%$.

Figura 6.9 Método de mapeamento aplicado individualmente nas amostras- segmentação em 5 grupos. Coluna RGB são imagens obtidas pelo software do microscópio; coluna LSM+Método imagens e gráficos obtidas pelo método. Linhas (a) bagaço in natura; (b) bagaço tratado com $\mathrm{H}_{2} \mathrm{SO}_{4}$ a $1 \%$; (c) bagaço tratado com $\mathrm{NaOH}$ a $0.5 \%$ e; (d) bagaço tratado com $\mathrm{NaOH}$ a $2.0 \%$.

Figura 6.10 Método de mapeamento múltiplo simultâneo, com segmentação espectral em 25 agrupamentos. Coluna RGB são imagens obtidas pelo software do microscópio; coluna LSM+Método imagens e gráficos obtidas pelo método. Linhas (a) bagaço in natura; (b) bagaço tratado com $\mathrm{H}_{2} \mathrm{SO}_{4}$ a $1 \%$; (c) bagaço tratado com $\mathrm{NaOH}$ a $0.5 \%$ e; (d) bagaço tratado com $\mathrm{NaOH}$ a $2.0 \%$.

Figura 6.11 Mapeamento de amostras de bagaço de cana-de-açúcar submetidas a tratamento hidrotérmico a $160^{\circ} \mathrm{C}$ em diferentes tempos: $(\mathrm{A})$ in natura; (B) $30 \mathrm{~min}$; (C) 45min e; (D) 60min.

Figura 6.12 Imagens de (A) fibras in natura;tratadas por organossolvente: pelos tempos de : (B) 50min; (C) 100min e; (D) 150min. . . . . . . . . . . . p. 101

Figura 6.13 Detalhes de: (A) Fibras in natura;tratadas por organossolvente; (B) Fibra que passou por tratamento combinado, hidrotérmico e organossolve, iniciado com hidrotérmico por 30 min e seguido por organossolve por 150min.p. 102

Figura 6.14 Esq. - Jacaranda caroba, planta (1), folhas (2), flores (3) e frutos (4); (Dir.) ocorrência no pais. p. 103

Figura 6.15 Amostras de cortes do Jacaranda caroba obtidas por coloração para microscopia ótica. (A) Controle; (B) $5 \mathrm{mg} / \mathrm{L}$; (C) $15 \mathrm{mg} / \mathrm{L}$; (D) 30mg/L; (E) $60 \mathrm{mg} / \mathrm{L} \mathrm{e}$; (F) $1162 \mathrm{mg} / \mathrm{L}$.

Figura 6.16 Imagens multiespectrais de amostras Jacarandá caroba após aplicação do método.(A) Controle; (B) $5 \mathrm{mg} / \mathrm{L}$; (C) $15 \mathrm{mg} / \mathrm{L}$; (D) $30 \mathrm{mg} / \mathrm{L}$; (E) 60

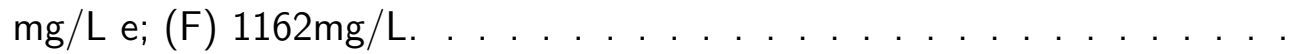


Figura 6.17 Folha controle. . . . . . . . . . . . . . . . . . p. 107

Figura 6.18 Concentração $5 m g / l \ldots \ldots$. . . . . . . . . . . . p. 108

Figura 6.19 Concentração $15 \mathrm{mg} /$ l . . . . . . . . . . . . . . . . . . . . . . p. p. 109

Figura 6.20 Concentração $30 \mathrm{mg} /$ l. . . . . . . . . . . . . . . . . . . . . . . p. p. 110

Figura 6.21 Concentração $60 \mathrm{mg} / \mathrm{l} \ldots \ldots$. . . . . . . . . . . . . . . p. 111

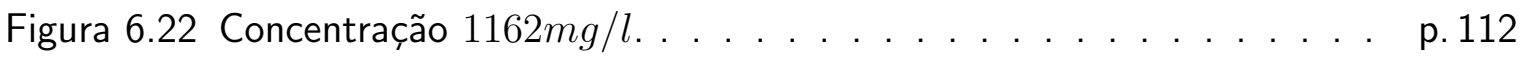

Figura 6.23 Matriz confusão do processo de classificação das assinaturas espectrais.p. 113

Figura 6.24 Acacia teuniflora. . . . . . . . . . . . . . . . . . . . . . . p. 115

Figura 6.25 Anacardium humile. . . . . . . . . . . . . . . . . . p. 116

Figura 6.26 Annona crassiflora. . . . . . . . . . . . . . . . . . . . p. 117

Figura 6.27 Annona tomentosa. . . . . . . . . . . . . . . . . . . . . . . . . p. 118

Figura 6.28 Aristolochia galeata. . . . . . . . . . . . . . . . . . . . . . . p. 119

Figura 6.29 Arrabidaea brachypoda. . . . . . . . . . . . . . . . . . . . . p. p. 120

Figura 6.30 Aspidospema subincanum. . . . . . . . . . . . . . . . . . . . . . p. 121

Figura 6.31 Baccharis salzmannii. $\ldots \ldots \ldots \ldots$. . . . . . . . . . . . . . 122

Figura 6.32 Banisteriopsis stellaris. . . . . . . . . . . . . . . . . . . . . p. 123

Figura 6.33 Bauhinia pulchella. . . . . . . . . . . . . . . . . . . . . . . . p. 124

Figura 6.34 Bauhinia ungulata. . . . . . . . . . . . . . . . . . . . p. 125

Figura 6.35 Byrsonima subterranea. . . . . . . . . . . . . . . . . . p. 126

Figura 6.36 Cavanillesia arborea. . . . . . . . . . . . . . . . . . . . . . . p. 127

Figura 6.37 Cissus erosa. . . . . . . . . . . . . . . . . . . . . . . . . . . p. 128

Figura 6.38 Cnidosculos urens. . . . . . . . . . . . . . . . . . . . . . . . . . . $\quad$ p. 129

Figura 6.39 Combretum duarteanum. . . . . . . . . . . . . . . . . . . . . . p. 130

Figura 6.40 Davilla elliptica. . . . . . . . . . . . . . . . . . . . . . . . . . . . p. 131

Figura 6.41 Duguetia furfuracea. . . . . . . . . . . . . . . . . . . . . . p. 132

Figura 6.42 Esenbeckia pumila. . . . . . . . . . . . . . . . . p. 133 
Figura 6.43 Guapira noxia. . . . . . . . . . . . . . . . . . . . . . . . . . p. 134

Figura 6.44 Kielmeyera abdita. . . . . . . . . . . . . . . . . . . p. 135

Figura 6.45 Leandra erostrata. . . . . . . . . . . . . . . . . . . p. 136

Figura 6.46 Maprounea brasiliensis. . . . . . . . . . . . . . . . . . . . . . . p. 137

Figura 6.47 Passiflora clathrata. . . . . . . . . . . . . . . . . . p. 138

Figura 6.48 Sabicea brasiliensis. . . . . . . . . . . . . . . . . . . . . . . . p. 139

Figura 6.49 Serjania lethalis. . . . . . . . . . . . . . . . . . . . p. 140

Figura 6.50 Smilax campestris. . . . . . . . . . . . . . . . . . . . . . p. 141

Figura 6.51 Tocoyena formosa. . . . . . . . . . . . . . . . . . . . . . . p. 142

Figura 6.52 Vernonia sp. . . . . . . . . . . . . . . . . . . . . . p. 143

Figura 6.53 Zeyheria montana. . . . . . . . . . . . . . . . . . . p. 144 



\section{SUMÁRIO}

1 Introdução $\quad$ p. 21

1.1 Microscopia confocal e construção de imagens . . . . . . . . . . . . . p. 21

1.2 Motivação . . . . . . . . . . . . . . . . . . . . . p. 23

1.3 Objetivo . . . . . . . . . . . . . . . . . . . . 26

1.4 Organização . . . . . . . . . . . . . . . . . . . . . . . . p. 26

2 Introdução à anatomia e ontogenia foliar $\quad$ p. 29

2.1 Função, anatomia, desenvolvimento e plasticidade foliar . . . . . . . . . p. 29

2.1.1 Função e anatomia foliar . . . . . . . . . . . . . . . . . . p. 29

2.1.1.1 Sistema dérmico . . . . . . . . . . . . . p. 31

2.1.1.2 Mesófilo . . . . . . . . . . . . . . . p. 32

2.1.1.3 Sistema vascular . . . . . . . . . . . . . p. 33

2.1 .2 Ontogenia foliar . . . . . . . . . . . . . . . p. 34

2.1.3 Influência ambiental na estrutura e forma foliar . . . . . . . . . p. 36

2.2 Considerações finais . . . . . . . . . . . . . . . . . . . . . . p. 39

3 Microscopia confocal de varredura à laser por fluorescência em biologia $\begin{array}{ll}\text { vegetal p. } 41 & \text { p. }\end{array}$

3.1 Fluorescência e espectros de absorção e emissão . . . . . . . . . . . . . p. p. 41

3.2 Microscopia confocal de varredura a laser, por fluorescência . . . . . . . p. 43

3.3 Visualização de imagens multiespectrais por softwares proprietários e implicações . . . . . . . . . . . . . . . . . . . . p. . 46 
3.4 Considerações finais . . . . . . . . . . . . . . . . . . . . p. 49

4 Imagens multiespectrais e métodos de processamento

4.1 Imagens multiespectrais . . . . . . . . . . . . . . . . . . p. 51

4.2 Substituição de bandas por outras descorrelacionadas . . . . . . . . . . . p. p 52

4.3 Mistura espectral . . . . . . . . . . . . . . . . . . . . . . p. 54

4.4 Visão, espectros e cores . . . . . . . . . . . . . . . . . . . . p. . 55

4.4 .1 Visão e Espectros . . . . . . . . . . . . . . . . . . . p. 55

4.4 .2 Sistemas de cores . . . . . . . . . . . . . . . p. 56

4.4.2.1 Sistema CIE RGB . . . . . . . . . . . . . . p. 57

4.4.2.2 Sistema CIE XYZ . . . . . . . . . . . . p. 57

4.5 Processamento . . . . . . . . . . . . . . . . . . . . p. 59

4.5.1 Processamento baseado no histograma . . . . . . . . . . . p. 59

4.5.2 Filtros em imagens . . . . . . . . . . . . . . p. 62

4.5.3 Multiresolução - wavelets . . . . . . . . . . . . . p. 65

4.6 Considerações finais . . . . . . . . . . . . . . . . . . . p. 69

5 Descrição do método desenvolvido $\quad$ p.71

5.1 Aquisição das imagens multiespectrais . . . . . . . . . . . . . . p. 72

5.2 Processamento Numérico f . . . . . . . . . . . . . . . . p. 72

5.3 Segmentação por agrupamento espectral . . . . . . . . . . . . p p. 76

5.4 Mapeamento e Visualização . . . . . . . . . . . . . . . . . . . . . p. 78

5.4.1 Comparação do método aplicado nos arquivos RGB e LSM, com o resultado de kmeans em RGB . . . . . . . . . . . . . . . . p. 81

5.4.2 Mapeamento simultâneo de múltiplas imagens . . . . . . . . . . p.83

5.5 Considerações finais . . . . . . . . . . . . . . . . . . p. 87

6 Resultados em biologia vegetal $\quad$ p. 89 
6.1 Microscopia confocal de varredura à laser aplicada em biologia vegetal . . p. 89

6.2 Resultados de análises de pré-tratamentos de bagaço de cana-de-açúcar . . p.92

6.3 Resultados da análise da plasticidade foliar do Jaracanda caroba . . . . . p. 103

6.4 Resultados na identificação pela assinatura espectral de plantas do Cerrado p. 113

7 Conclusões $\quad$ p. 145

$\begin{array}{ll}\text { REFERÊNCIAS } & \text { p. } 147\end{array}$ 



\section{CAPÍTULO 1}

\section{Introdução}

Neste capítulo será discorrido brevemente o surgimento da microscopia confocal de varredura a laser por fluorescência e algumas questões com relação à geração e análise de imagens multiespectrais.

O que é apresentado tem como finalidade contextualizar os processos de representação de imagens multiespectrais produzidas pelos atuais softwares que acompanham esses microscópios e que, por não considerarem sua dependência em relação à tecnologia de geração de imagens, acabam por influenciar os resultados produzidos, ocultando informações relevantes na amosta estudada. O problema, identificado e apontado neste capítulo, é a motivação para a busca de uma solução clara e precisa na forma de representar e analisar imagens multiespectrais objetivo central deste trabalho.

\subsection{Microscopia confocal e construção de imagens}

Enquanto a microscopia ótica tem por objetivo capturar imagens de uma amostra, colocando a região de interesse dentro de um campo focal, a microscopia confocal obtém a imagem de forma muito mais precisa, pois realiza a captura ponto focal, por ponto focal. Esse processo, embora seja muito mais preciso, apresenta uma característica peculiar: para se obter a imagem completa de uma amostra, torna-se necessário a varredura desta, ponto por ponto e linha por linha.

Vinte anos após sua criação, em 1973, são publicadas as primeiras imagens digitalizadas, sendo que, a partir dos anos 1980, com o desenvolvimento de teorias e técnicas para síntese de imagens, é construído o primeiro microscópio confocal, no qual se integraram os avanços tecnológicos do laser e da computação. Essa última tecnologia teve, a partir dos anos 1990, um crescimento exponencial refletido principalmente na área de hardware, possibilitando o surgimento de processadores e memórias RAM cada vez mais rápidos e de maior capacidade, 
assim como os discos rígidos, tornando-os capazes de armazenar grandes volumes de dados característica fundamental quando se trata da síntese e manipulação de imagens.

Atualmente, os microscópios confocais são capazes de capturar, simultaneamente, emissões de fluorescência de diversos comprimentos de onda (ou canais) entre 400nm(ultra-violeta) e $800 \mathrm{~nm}$ (infra-vermelho). As imagens multiespectrais resultantes de cada captura possuem dimensões $M x N x C$ onde $M x N$ correspondem às dimensões espaciais da imagem e $C$ ao número de canais que compõem a respectiva assinatura espectral de cada coordena mxn.

Por meio dessa matriz tridimensional $(M x N x C)$, o software do respectivo fabricante gera uma imagem colorida utilizada pelo pesquisador, como referência para a seleção de regiões de interesse, como mostra a Figura 1.1 $(a-c)$.
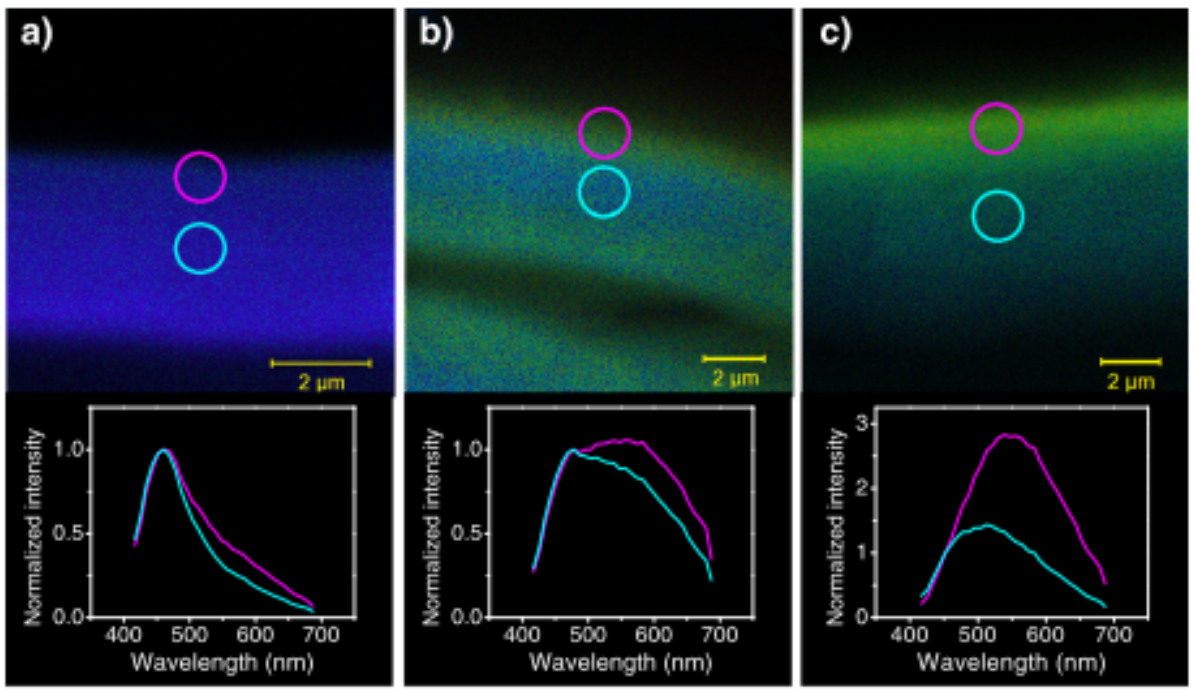

Figura 1.1 - Imagens espectrais da parede celular de bagaço de cana e os respectivos espectros obtidos pela seleção de regiões na imagem de referência: a) fibra controle; b) fibra tratado com $\mathrm{H}_{2} \mathrm{SO}_{4}$ e; c) Fibra tratada com $\mathrm{NaOH}$ após tratamento de $\mathrm{H}_{2} \mathrm{SO}_{4}$.

Fonte(s): COLLETA et al.(71).

Quando uma imagem de captura multiespectral é apresentada em um monitor, o que se pretende ver? E, principalmente, o que realmente se vê?

Embora não seja o escopo deste capítulo, alguns conceitos de construção de imagens e cor são rapidamente apresentados para melhor contextualizar os problemas identificados e justificar o método desenvolvido. Em momentos oportunos, os capítulos seguintes tratarão melhor os conceitos aqui abordados.

Responder à primeira questão, de uma forma genérica, é relativamente simples. Quando se faz uso de uma captura multiespectral, em um microscópio confocal por fluorescência, deseja- 
se obter informações espectrais da amostra, ao longo de sua extensão, de forma muito precisa. As assinaturas espectrais e sua distribuição espacial pela imagem informam as propriedades físico-químicas das estruturas presentes na amostra .

Para responder à segunda questão, " ...o que realmente se vê? ", é necessário entender um pouco sobre o funcionamento da visão humana, a formação de imagens em monitores coloridos e como é realizada a representação de uma assinatura espectral.

O olho humano possui células, chamadas de cones, os quais são classificados em três tipos: S, M e L. Cada um desses tipos são mais sensíveis, respectivamente, aos comprimentos de ondas próximos ao azul, verde e vermelho. Pela combinação de estímulos desses cones, são geradas (em nosso cérebro) as demais cores que conhecemos. Essa constatação determinou a construção de um sistema de cores tricromático (CIE RGB - vermelho/verde/azul), o qual tem sido utilizado como base, desde os primeiros televisores coloridos, até aos atuais monitores LCD (se atentamente observados com uma lupa, é possível notar que os pixels nos monitores são compostos por três partes coloridas, uma vermelha, uma verde e outra azul, que variam sua intensidade luminosa).

No caso da representação de uma assinatura espectral, deve-se considerar que essa, quando composta por comprimentos de onda dentro do espectro visível, resulta em uma única cor para o sistema visual humano e, portanto, pode ser reproduzida em um monitor por meio do mesmo sistema de cores CIE RGB, anteriormente citado.

\subsection{Motivação}

É exatamente esse processo de conversão e apresentação de assinaturas espectrais que ocorre nos softwares de microscopia multiespectral. As assinaturas contidas nas matrizes multiespectrais são convertidas em uma cor correspondente, resultando em uma imagem colorida, que é apresentada em um monitor.

Considerando-se a padronização e precisão de todo o processo, não deveria haver problema algum na construção desse tipo de imagem. Entretanto, se esquece que a cor é uma experiência pessoal e a nossa capacidade de observar nuances de cor é pequena, suscetível à interferência de textura e contraste e, principalmente, assinaturas espectrais possuem grande probabilidade de serem representadas por uma mesma cor, para o espaço de cores CIE RGB; devido à redução de espaço dimensional (de um espaço de 32 para um espaço de dimensão 3 ).

Assim, o problema identificado é que uma assinatura espectral não pode ser reduzida a uma cor, da forma que vem sendo feita. 
O que os atuais microscópios confocais multiespectrais mostram, em seus monitores, não são espectros mas cores resultantes de assinaturas espectrais cujas dimensões foram reduzidas para um espaço de cor de dimensão três. Esse tipo de conversão em cor, embora seja executada com embasamento conceitual, não é adequado para representar variações espectrais e, muito menos, contempla o volume de informação que uma assinatura multiespectral carrega.

O resultado final desse processo é a perda de informações valiosas da amostra, não pela falta da qualidade na captura realizada pelo microscópio, mas pela forma da apresentação da informação, que pode, inclusive, induzir a interpretações falsas sobre a imagem apresentada.

Para se entender a complexidade do problema, observe a Figura 1.2-a. Essa é uma imagem obtida em um microscópio confocal multiespectral com captura de trinta e dois canais, da parede celular de uma fibra vegetal, especificamente de uma parede celular de cana-de-açúcar.

Na Figura 1.2-b tem-se uma representação gráfica do que se conhece sobre a concentração de agregados de lignina ao longo de uma parede celular vegetal, sendo que a concentração de agregados aumenta à medida que se aproxima da borda externa da parede(parte superior) e diminui à medida que se desce em direção à borda interna (parte inferior).

Considerando-se o que foi descrito no parágrafo anterior em comparação com o resultado obtido pelo microscópio em termos de imagem na Figura 1.2-a, essa última não reflete visualmente essa variação de densidade de agregados representada por 1.2-b.

Analisando-se a imagem 1.2-a, toda a extensão da amostra é apresentada por uma área azul, conduzindo ao entendimento de uma suposta presença homogênea de lignina, o que não é real, conforme demonstram as diferentes assinaturas espectrais, obtidas em duas regiões selecionadas manualmente. Essas assinaturas indicam haver diferenças nas densidades de agregados de lignina, sendo consistente com o diagrama 1.2-b, mas, em termos de imagem, as cores resultantes das assinaturas espectrais não são capazes de tornar visível essas diferenças.

Deve-se também notar que, se o pesquisador não possuir o conhecimento prévio dessa variação de concentração de agregados, poderia selecionar regiões da amostra horizontalmente alinhados, havendo a possibilidade de se obterem assinaturas quase idênticas, conduzindo-o, por fim, a conclusões possivelmente falsas sobre a distribuição de lignina na amostra.

Portanto, a questão que este trabalho coloca e responde é: como tornar uma imagem multiespectral visível, considerando as limitações do observador e do padrão CIE RGB?

Frente a essas constatações, foi realizado um levantamento bibliográfico em busca de possíveis soluções para os problemas levantados. Quanto às áreas que fazem uso intenso da microscopia multiespectral, foi possível notar que os trabalhos publicados a tem como uma 
ferramenta de pesquisa, e não como um objeto de estudo no sentido de se obterem melhorias na extração de informações.

Os principais algoritmos e métodos para tratamento de imagens multiespectrais encontrados estão em publicações de áreas como geociências, sensoriamento remoto e afins $(44-46)$. Essas áreas, por terem grande interesse na aquisição e identificação da informação provinda de imagens multiespectrais, têm dispendido esforços para o desenvolvimento contínuo de técnicas e algoritmos $(15,42,52,57)$. Entretanto, mesmo nessas áreas, não foi possível encontrar nenhum método que pudesse resolver as questões acima levantadas.

Assim, observou-se a necessidade de se desenvolver um método capaz de realizar um mapeamento pixel-a-pixel, que permitisse a visualização e qualificação espectro-espacial de uma amostra, relacionando cada pixel ao seu respectivo espectro. A Figura 1.2-c mostra o resultado obtido pela aplicação do método desenvolvido neste trabalho e que soluciona os problemas acima levantados.

O método foi aplicado na mesma amostra apresentada pela Figura 1.2-a. Deve-se notar que ele foi capaz de mapear a presença de espectros, não mais por região, mas pixel-apixel sendo, inclusive, bastante consistente com as assinaturas das regiões da Figura 1.2-a e evidenciou claramente a estratificação dos agregados de lignina no corte da parede celular, conforme já predito por pesquisadores da área e, até o momento da escrita deste trabalho, nunca obtido uma imagem direta.

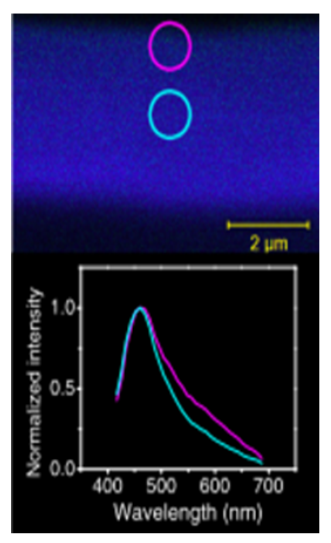

(A)

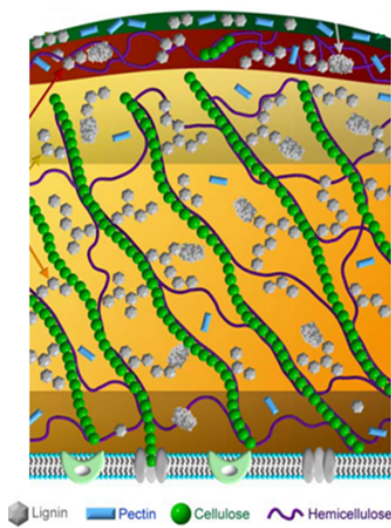

(B)

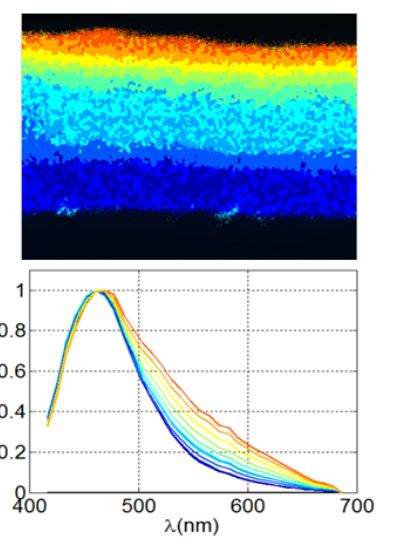

(C)

Figura 1.2 - Imagens de uma parece celular vegetal: (a) parece celular obtida por microscopia confocal de varredura à laser; (b) diagrama da concentração de agregados de lignina de uma parede celular vegetal; (c) imagem após processamento pelo método desenvolvido da imagem multiespectral (a).

Fonte(s): (a) COLLETA et al.(71); (b) Adaptada de ACHYUTHAN et. al (73); (c) Elaborada pelo autor. 


\subsection{Objetivo}

Desenvolver e implementar um método de mapeamento espectral pixel-a-pixel que permita a visualização espectro-espacial de imagens multiespectrais, obtidas por fluorescência por microscopia CLSM e sua aplicação nos estudos:

- de pré-tratamentos para retirada de lignina da parede celular;

- da plasticidade do jacarandá caroba e;

- do uso de assinaturas espectrais na caracterização de espécies vegetais do Cerrado.

\subsection{Organização}

Este trabalho é composto por sete capítulos. O segundo capítulo tem o objetivo de fornecer subsídios teóricos (anatômicos e funcionais) da estrutura foliar, que permita o entendimento das informações obtidas das imagens espaço-espectrais e fornece conceitos de anatomia, ontogenia e a influência ambiental com relação à estrutura foliar. A função e a anatomia foliar e os seus três principais tecidos sistema dérmico, mesófilo e sistema vascular, são descritos. $\mathrm{O}$ terceiro capítulo descreve os princípios básicos envolvidos na microscopia confocal à laser e o processo envolvido na captura de imagens por fluorescência.

O quarto capítulo trata dos conceitos e definições de imagens multiespectrais e hiperespectrais e dos problemas específicos no que se refere ao seu processamento. Também aborda, de forma introdutória, os conceitos e a relação entre visão, cores e espectro e, sobre os sistemas de cores CIE RGB, CIE XYZ e o CIExy e seu referido diagrama de cores. Neste capítulo, também foram abordados os conceitos de processamento de imagens baseados em histograma, filtros de suavização (no domínio do espaço e frequência - com a transformada de Fourier).Por fim, o capítulo é finalizado com os conceitos de multi-resolução, com uso de wavelets.

No quinto capítulo, o método proposto é descrito, etapa por etapa, e um teste de comparação deste é mostrado - comparou-se: uma imagem RGB na qual foi aplicada uma segmentação por kmeans; uma imagem RGB na qual foi aplicado o método e; o resultado da aplicação do método proposto, diretamenta sobre uma arquivo multiespectral(formato LSM), ação que esta tese propõem. Nesse capítulo também é mostrado um teste de aplicação de mapeamento múltiplo e simultâneo de imagens multiespectrais, demonstrando a capacidade 
do método de realizar uma comparação espectral e de ocorrência espectral entre amostras distintas - isto é, de forma qualitativa e quantitativa.

O sexto capítulo apresenta os resultados obtidos pelo método, em três estudos: no mapeamento espectral de fibras de bagaço-de-cana, submetidos a pré-tratamentos físicos e químicos, para a extração de lignina; no estudo da plasticidade foliar do Jaracanda caroba e seu uso como um bio-sensor de poluentes e; no uso das assinaturas espectrais, na classificação de espécies de plantas do cerrado. Por fim, o sétimo capítulo traz as conclusões finais. 


\section{CAPÍTULO 2 \\ Introdução à anatomia e ontogenia foliar}

\subsection{Função, anatomia, desenvolvimento e plasticidade foliar}

O objetivo desta seção é fornecer uma introdução básica sobre tecido vegetal foliar e sua formação. Para isso, este capítulo foi dividido em três subseções: função e anatomia, ontogenia e influência ambiental na estrutura e forma foliar.

\subsubsection{Função e anatomia foliar}

A folha é um órgão estrutural e fisiologicamente especializado, de crescimento determinado e cuja forma geralmente achatada tem função fotossintética. Suas características anatômicas funcionais são fundamentais para determinar sua capacidade de adaptação a um dado habitat(10).

Uma folha pode ser classificada morfologicamente como microfila, cujo termo se refere às pequenas folhas cuja estrutura está diretamente conectada ao caule ou; macrofila, que são os tipos de folhas tradicionalmente conhecidas, cuja lâmina foliar está ligada ao caule por um pecíolo (11).

Sobre sua constituição, uma folha é considerada simples, se única lâmina foliar é ligada ao caule por um pecíolo. Caso haja, no pecíolo que se liga au caule, vários folíolos, essa folha é classificada como composta. Os folíolos podem surgir de um ponto central do pecíolo, ou aos pares, ao longo do eixo central. Exemplos de folhas simples e compostas podem ser vistas na Figura 2.1 ). 

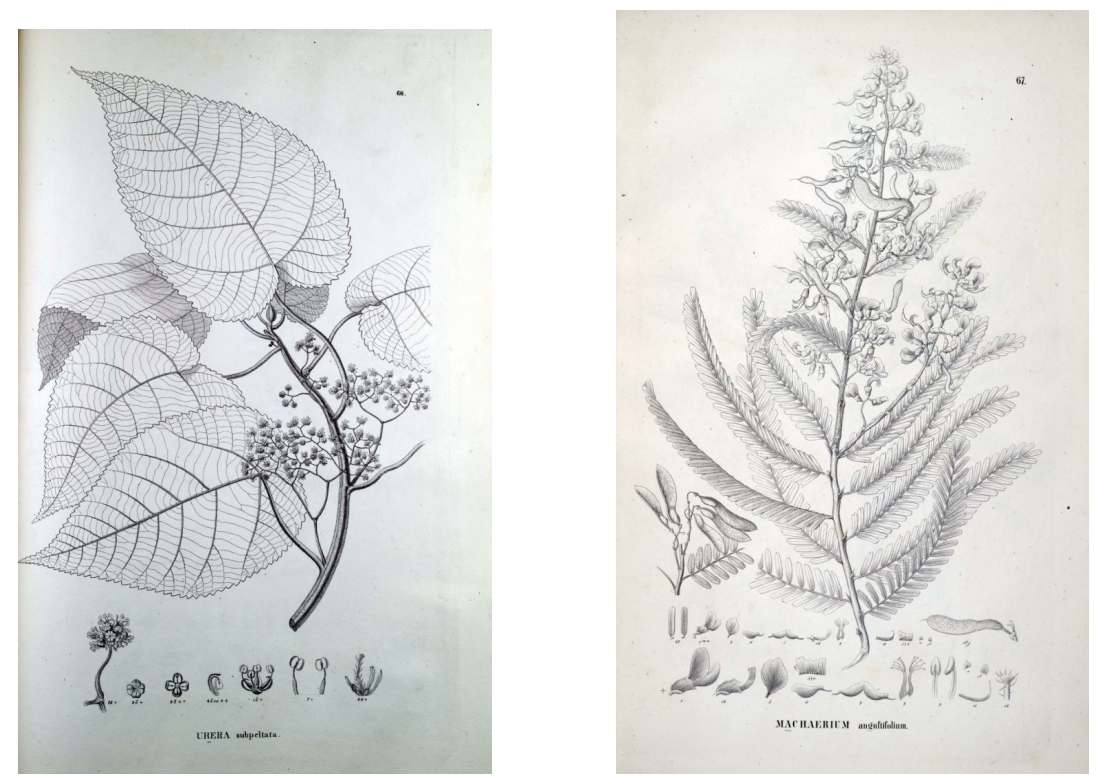

Figura 2.1 - Exemplos de plantas com folhas simples Urera subpeltata [Miq.] (esq.)

e folhas compostas Machaerium anguftifolium [Benth.] (dir.).

Fonte(s): esq. MIQUEL (74); dir. BENTHAM (82).

Uma folha é composta por três sistemas principais de tecidos: o tecido dérmico (epiderme superior e epiderme inferior); tecido fundamental ou mesófilo (constituído por tecido paliçádico e tecido esponjoso) e sistema vascular. Para as folhas compostas por essa configuração estrutural de tecidos, dá-se o nome de folhas dorsiventrais. Quando há uma camada de tecido paliçádico entre o mesófilo esponjoso e a epiderme inferior, resultando em uma simetria estrutural, têm-se folhas isolaterais ou isobilaterais(11).(Figura 2.2).
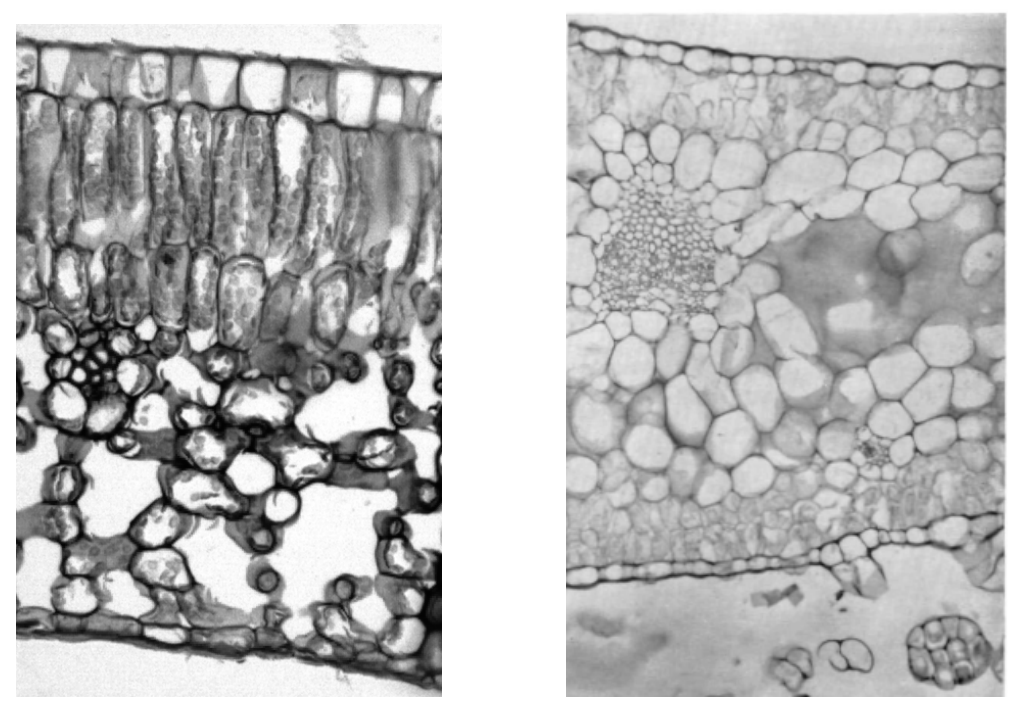

Figura 2.2-Corte foliar : esq. folha dorsiventral; dir. isolateral.

Fonte(s): esq. Rosana Kolb*; dir. CARLQUIST (76).

*Imagem gentilmente cedida por Rosana Kolb. 


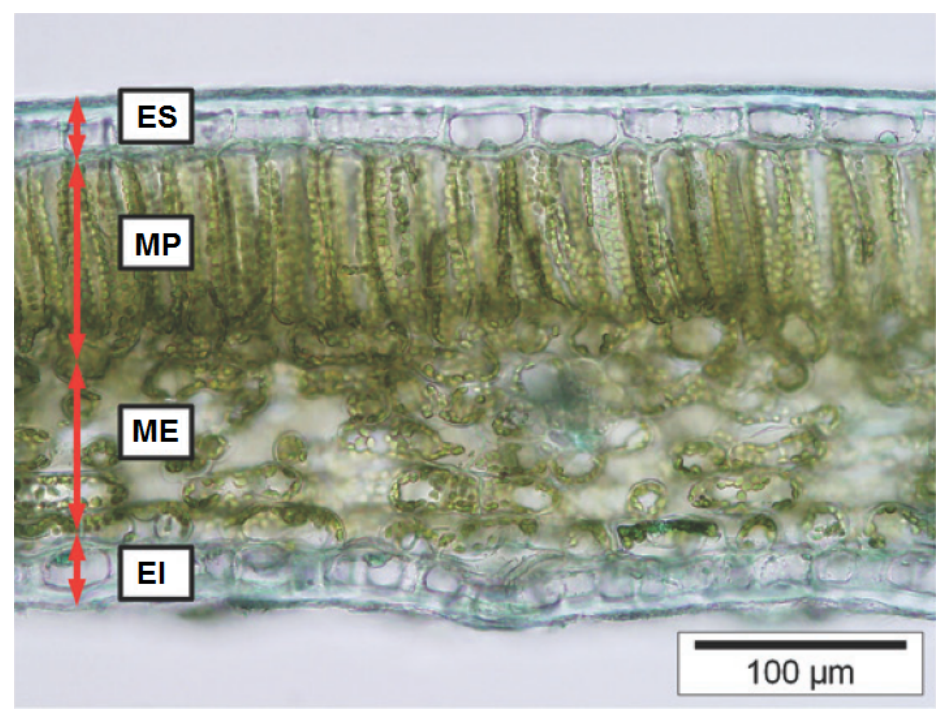

Figura 2.3 - Partes constituintes de um tecido foliar: ES- epiderme superior; MPmesófilo paliçádico; ME- mesófilo esponjoso; El- epiderme inferior.

Fonte(s): ONODA et al. (75).

A Figura 2.3 mostra um corte foliar transversal com suas principais principais estruturas (sistema dérmico - epidermes superior e inferior, mesófilo paliçádico e mesófilo esponjoso). Estas estruturas são descritas nas subseções seguintes.

\subsubsection{Sistema dérmico}

As epidermes superior e inferior, que formam o sistema dérmico, são constituídas por uma camada de material ceroso denominado de cutícula, proveniente da cutina. Na epiderme superior ou adaxial (face superior), a cutícula tem espessura relativamente maior do a cutícula presente na epiderme inferior ou abaxial (face inferior).

Abaixo dessa cutícula, a epiderme adaxial e pode ser constituída por uma única ou múltiplas camadas de células, variando de 2 a 16, conforme a espécie da planta. Ocasionalmente, a paredes dessas células contêm lignina e frequentemente cutina $(10,11)$. Acredita-se que a função das camadas múltiplas seja, provavelmente, o de proteger o mesófilo da excessiva dissecação.

A epiderme abaxial pode ter mais camadas, do que a camada adaxial e geralmente, associada a isto, há a presença de cavidades subestomática de considerável tamanho, cujo acesso do $\mathrm{CO}_{2}$ é regulado pela abertura e fechamento dos estômatos, com o aumento ou diminuição da abertura controlada pelas células guarda. Embora a presença de estômatos (Figura 2.4) seja mais frequente na superfície abaxial, podem-se encontrar estômatos também na superfície adaxial $(10,11)$. 


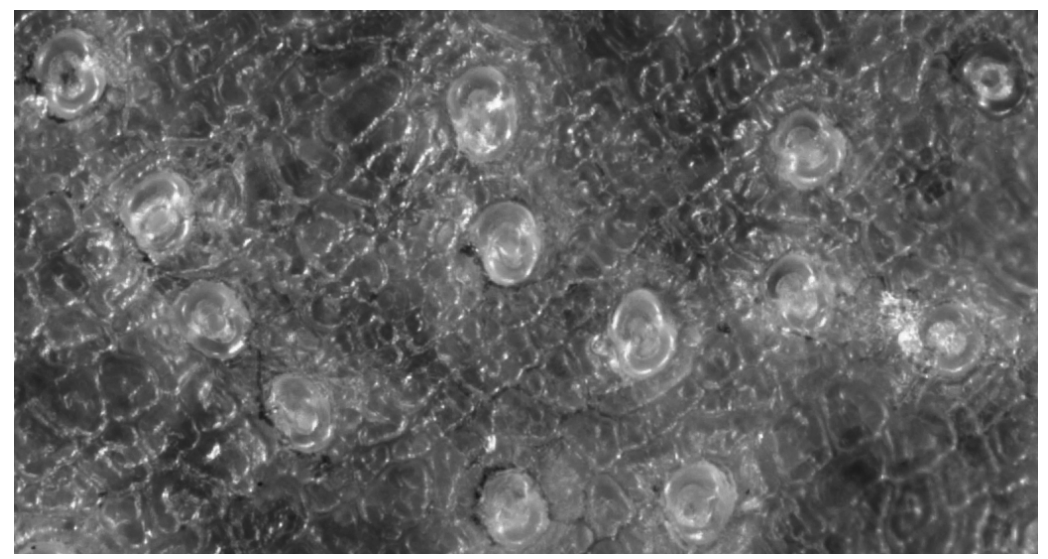

Figura 2.4-Estômatos na superfície foliar.

Fonte(s): Elaborada pelo autor.

\subsubsection{Mesófilo}

O mesófilo é a camada responsável pela função fotossintética da folha, o qual é subdividido em paliçádico e esponjoso. O tecido paliçádico é o principal responsável pelo processo fotossintético, por apresentar uma maior concentração de cloroplastos no interior de suas células $(8,11)$.

Logo abaixo da epiderme superior, esse tecido é formado por uma ou mais camadas de células parenquimáticas, cujas formas são aproximadamente cilíndricas e, alongadas transversalmente ao plano da folha. Na sequência do tecido paliçádico, há o mesófilo esponjoso. Este é composto por células parenquimáticas de forma irregular, com numerosos cloroplastos esparsos, e bem diferenciáveis $(10,11)$. Entre essas células parenquimáticas, há grandes espaços intercelulares compondo as sub-câmaras estomáticas, onde nas quais ocorrem as trocas gasosas resultantes da fotossíntese ou respiração foliar $(8,10)$.

Segundo Cutter (12), o papel da anatomia do mesófilo é o de restringir a condutância do $\mathrm{CO}_{2}$, o que explica a variabilidade fotossintética entre espécies. Com relação a esse aspecto anatômico foi o que também concluiu(13) em um estudo do efeito da variação de suprimento de potássio no processo fotossintético pela condutância de difusão do mesófilo - Esse experimento observou uma considerável variação da quantidade de clorofila no mesófilo.

Há vários trabalhos que tentam relacionar a estrutura foliar com o desempenho fotossintético. Um índice usado é o LMA(Leaf dry mass per area), isto é, a razão entre o valor de massa foliar seca por sua área foliar quando túrgida, o qual pode ser relacionado com o volume do mesófilo $(10,11)$. Entretanto, isso não implica em uma alta taxa fotossintética como é descrito em (8) no que se constatou que a Banksia apresentava uma alta densidade de 
tecido, mas não apresentava atividade fotossintética proporcional, demonstrando que as taxas fotossintéticas por unidade de área são independentes do fator LMA(11).

\subsubsection{Sistema vascular}

O sistema vascular ou de venação está presente predominantemente na região central da folha e se estende por toda lâmina foliar. Os feixes vasculares, que tem como função o transporte da seiva bruta ( água e sais minerais dissolvidos - ), é chamado de xilema. A seiva elaborada é transportada por outro feixe vascular denominado de floema. A configuração espacial dos sistema de nervação é bem marcante entre as dicotiledôneas e monocotiledôneas (Figura 2.5).

Nas dicotiledôneas (Figura 2.5-dir.) há um feixe vascular principal também denominado de nervura central, do qual partem ramificações menores, formando um reticulado. Nas monocotiledôneas (Figura 2.5-esq.), esse sistema de venação é paralelo, e os feixes são semelhantes e interligados por pequenas nervuras, de forma perpendicular à linha dos feixes. Por ser continuidade do caule, os feixes do xilema são orientados para o lado adaxial e os do floema, para o lado abaxial(10).
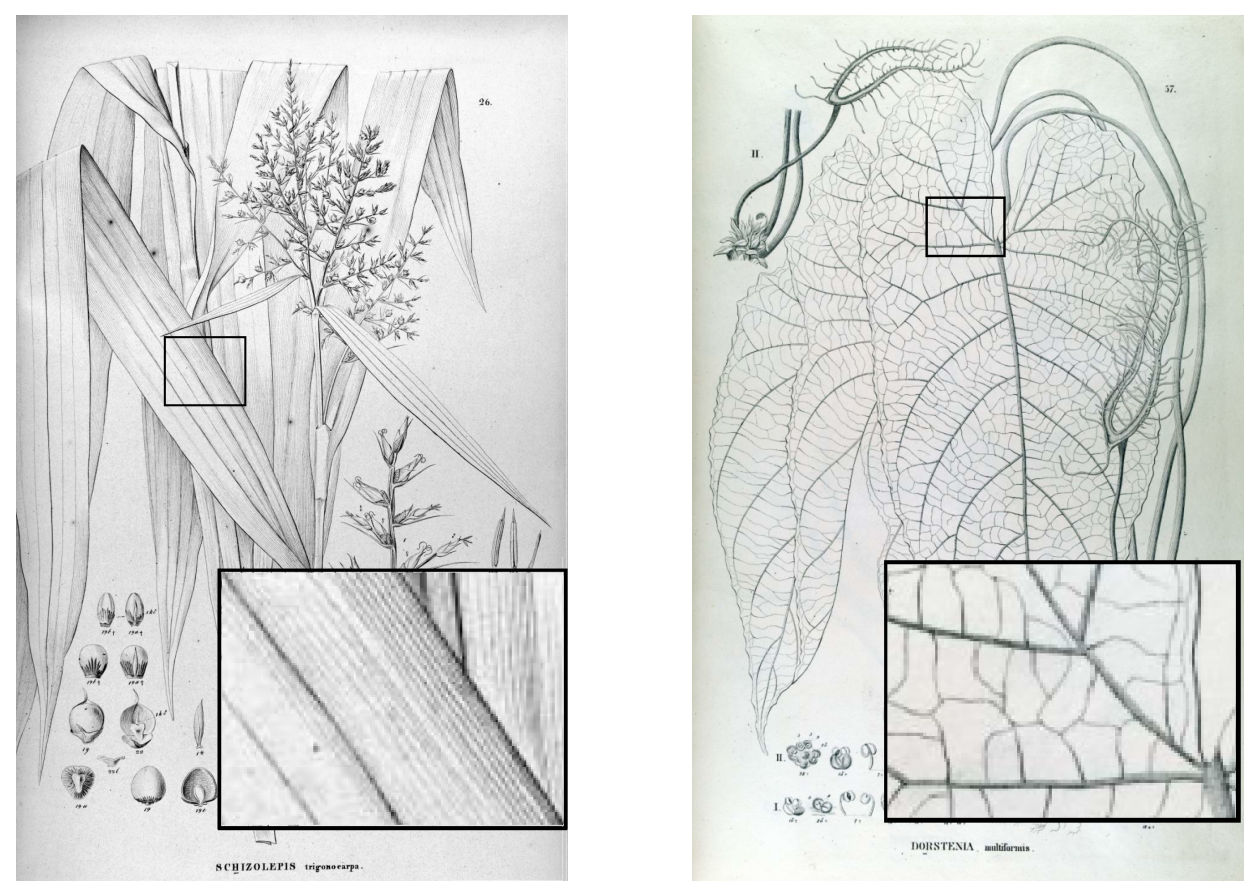

Figura 2.5 - Exemplos de sistemas de venação de uma monocotiledônea Schizolepis trigonocarpa [Nees](esq) e dicotiledônea Dortenia multiformis [Miq.] (dir). 


\subsubsection{Ontogenia foliar}

A presença de variação da forma da folha em um mesmo indivíduo é uma característica presente entre algumas espécies. Esta característica é denominada de heteroblastia. Resultante da ação de tecidos meristemáticos, a heteroblastia é a consequência de uma programação genética ou influência de condições ambientais(11). Quando o formato das folhas é uma constante em todas as fases de vida de uma espécie vegetal, se diz que esta possui um desenvolvimento homoblástico(11).

O tipo de desenvolvimento homoblástico ou heteroblástico de uma espécie é definido pela ação simultânea ou sequencial dos tecidos meristemáticos, que atuam durante a ontogenia foliar. Cada tipo de tecido meristemático, recebe sua denominação conforme sua região de atuação: meristema: apical, adaxial, abaxial e marginal. Compreender a forma e estrutura de uma folha, implica em compreender todo o seu processo de formação, crescimento e desenvolvimento, o qual se inicia no ápice do caule $(10,11)$.

No ápice do caule, o meristema apical é o mais ativo no início da fase do desenvolvimento (Figura 2.6). Dele, parte um processo de divisão celular periclinal, dando origem à epiderme do primórdio foliar, fazendo com que sua estrutura seja projetada do ápice(10).

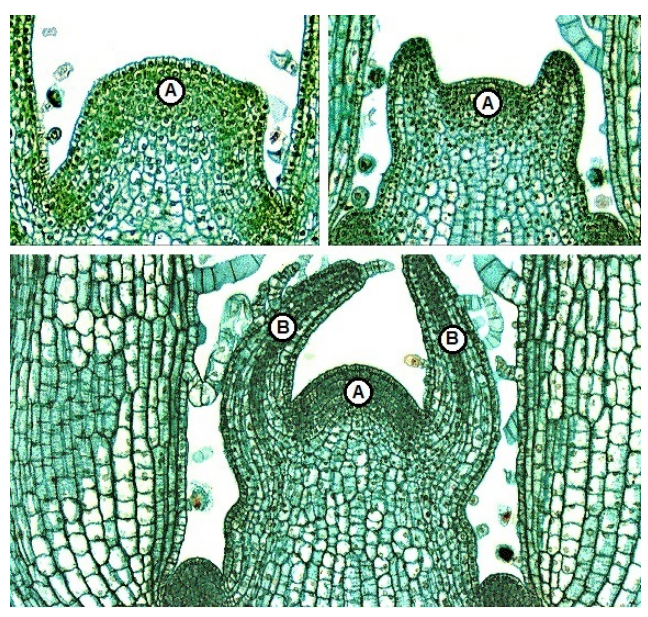

Figura 2.6 - Sequência de desenvolvimento do meristema foliar: (a) primórdio foliar; (b) meristema

Fonte(s): ROBERTS (77).

Durante o desenvolvimento do primórdio foliar, esse se inclina temporariamente em direção ao ápice do caule, devido ao aumento da atividade meristemática abaxial, com o desenvolvimento do primórdio foliar, no eixo foliar basal-apical; que ocorre por meio de sucessivas divisões celulares e também por crescimento intercalar(10). Estudos desse processo de diferenciação podem ser vistos em (9). 
Nas primeiras fases do crescimento do primórdio foliar, os meristemas marginais podem ser observados como sendo expansões laterais, cujo crescimento contribuirá na definição da forma da folha e, está relacionado ao crescimento dos lobos foliares e também na definição do número de camadas de células do mesófilo(10).

Abaixo da epiderme adaxial do lado superior da folha está localizado o meristema adaxial. Este atua no espessamento do pecíolo e da nervura, em função de suas sucessivas divisões.(10) O espessamento do pecíolo e da nervura, se concentram na região superior da folha, no período de crescimento da desta, e depois passa a se concentrar no em seu interior(10). Por fim, a forma de uma folha resulta da interação do meristema intercalar e adaxial, o qual, gradativamente, é substituído pela atividade meristemática intercalar. A intensidade da atividade e interação desses meristemas tem grande influência na forma da folha(10).

O crescimento lateral se dá pelo estabelecimento de camadas de células na lâmina foliar, que se dividem, fazendo com que essa se expanda lateralmente resultando em uma pequena placa de células, funcionando como um meristema em placa (10).

O tecido paliçádico surge da diferenciação celular das células adaxiais, do meristema marginal. Nesse tecido, sua divisão celular geralmente continua em uma taxa mais alta, e por mais tempo, do que em qualquer outra parte da folha - devido provavelmente à maior persistência de tempo, que o tecido possuí na síntese de $\operatorname{DNA}(10,11)$. Possivelmente isso também explique o maior índice de sucesso de cultura desse tecido, quando comparado ao mesófilo esponjoso $(10,11)$.

A origem do mesófilo esponjoso, por sua vez, é proveniente da camada abaxial. Segundo Cutter(10), as ramificações das células do mesófilo esponjoso e a formação dos espaços intercelulares são o resultado da tração exercida pelas células da epiderme que continuam a se expandir, após o término da expansão do mesófilo médio e abaxial, e essa mesma força de tração estaria presente na epiderme inferior(10).

O desenvolvimento do sistema de venação está relacionado à distribuição do crescimento foliar, embora fatores de crescimento meristemático podem estar envolvidos na diferenciação do tecido procambial, que dariam origem às nervuras $(10,11)$. No caso das dicotiledôneas, a ontogenia partiria do cordão primário (ou nervura central), se diferenciando em reação ao crescimento apical do primórdio. Esse conceito parece se fortalecer ao se observarem as nervuras secundárias, que estão diretamente relacionadas aos lobos, serrilhas ou dentes da borda foliar - influência do meristema marginal(10). 


\subsubsection{Influência ambiental na estrutura e forma foliar}

São, principalmente nas folhas, refletidas as alterações de plantas que crescem em determinados nichos ecológicos. Essas plantas possuem adaptações particularmente relacionadas ao seu habitat e são divididas em três grupos: plantas xerófitas, hidrófitas e mesófitas(11).

A escassez de água é uma constante no habitat das plantas xerófita, por isso, suas foIhas são espessas e coriáceas e possuem uma cutícula bem desenvolvida e tricomas (pelos) abundantes(11). A epiderme e subepidermes são lignificadas com a possibilidade da presença de uma hipoderme e seu mesófilo é bem definido, normalmente com mais de uma camada de tecido paliçádico. O sistema vascular (nervuras) é bem desenvolvido com abundância de esclerênquima(11).

As plantas aquáticas ou hidrófitas apresentam variações anatômicas entre espécies, e também para as folhas de superfície e folhas submersas. Os estômatos, em folhas de superfície (flutuantes), se restringem à parte superior para permitir trocas gasosas com o ambiente. As folhas submersas geralmente são segmentadas e delgadas com tecidos paliçádico e esponjoso não diferenciáveis, com o mesófilo reduzido a umas poucas camadas de células(10). O xilema se apresenta bastante reduzido, em contraste com um abondante floema(11). Segundo Cutter (11), isto pode ser explicado pelo fato do ambiente aquático fornecer os solutos necessários, permitindo a planta direcionar sua energia em um sistema de venação para a distribuição da seiva elaborada(floema).

As plantas mesófitas, de ambientes úmidos, possuem uma estrutura foliar que as diferencia em função da intensidade luminosa à qual são expostas; mesmo dentro de uma mesma espécie ou até mesmo indivíduo(11). As folhas expostas à luz tornam-se mais espessas, possuem mais tricomas e menor área foliar, quando comparadas com as de mesma espécie, que estão em regiões sombreadas(11). Diferentes regiões de uma árvore também mostram modificação na estrutura foliar, conforme a quantidade de luz a que foi exposta(11). Cutter(11) cita um caso de folhas que ficaram em regiões sombreadas, cujo volume médio das células paliçádicas eram $60 \%$ menores e o mesófilo esponjoso $40 \%$ menor, além de se apresentar difuso $(10,11)$. Deveve-se notar que houve uma variação do volume celular e não do número das camadas celulares - o que, possivelmente, seria um parâmetro interessante para a caracterização de uma espécie. Embora haja casos, como o Acorus calamus de regiões diferentes, que se diferiam com relação ao crescimento radial. A diferença era o número celular e não tamanho celular (11). No caso em que folhas eram expostas diretamente ao sol, apresentaram o parênquima paliçádico bem desenvolvido e de forma colunar e o parênquima lacunoso era frouxamente arranjado. 
Duas tentativas de explicar o mecanismo dessas configurações, são citadas por Cutter, as linhas de Hughes e Dostál (11).

Hughes parte do princípio de que as diferenças são resultantes da estrutura de maturidade da planta, sendo que a atividade meristemática seria idêntica para ambientes luminosos ou sombreados.

Dostál considera que as ações meristemáticas têm uma ação determinante no desenvolvimento foliar, em resposta às condições ambientais de luz. Pois foi possível observar que, no caso de árvores, os primórdios foliares já são irreversivelmente determinados na gema, caso essa seja exposta ao sol ou à sombra- exercendo uma influência determinante no início do desenvolvimento foliar. Nas plantas herbáceas, esse reflexo da ação meristemática pode ser obtido nos estágios finais do desenvolvimento foliar.

Cutter(11) também chama a atenção de que pode existir uma relação causal, em vez de adaptativa, entre o meio e a estrutura, e que as relações causal e adaptativa também podem ocorrer conjuntamente, isto é, não são mutuamente exclusivas.

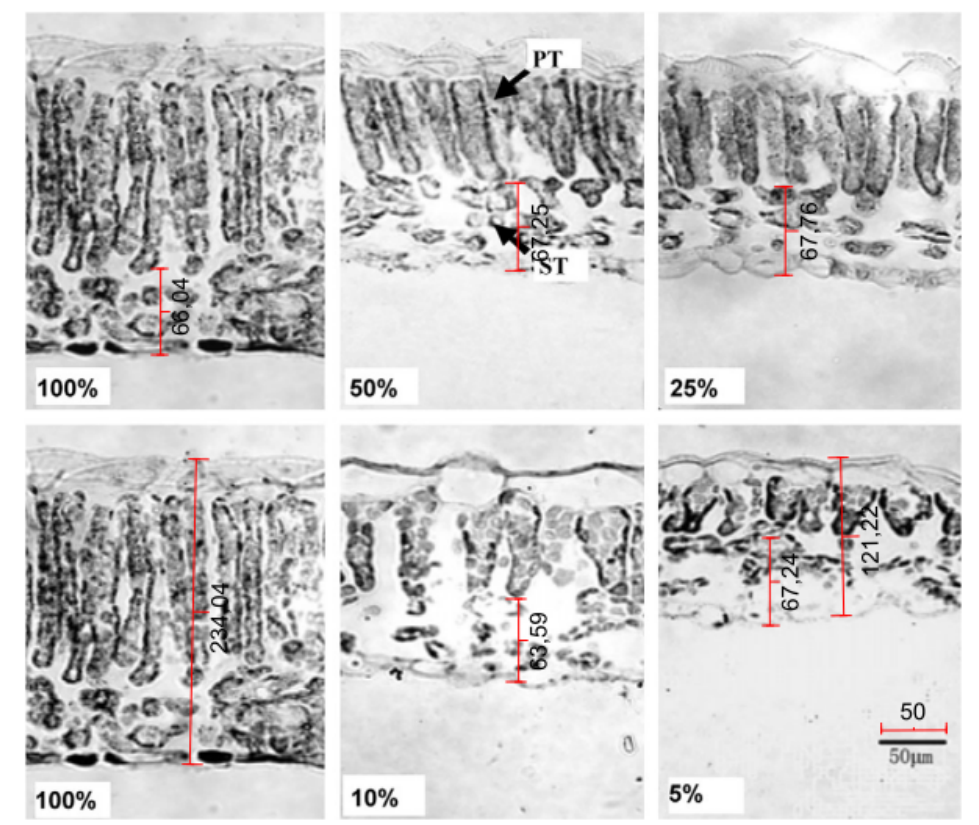

Figura 2.7 - Corte transversal mesófilo paliçádico (PT) and esponjoso (ST) do tecido foliar de R. typhina de plantas desenvolvidas em cinco diferentes intensidades luminosas : 100\% (CK), 50\% (T1), 25\% (T2), 10\% (T3) and $5 \%$ (T4). Barra de referência $1 b a r=50 \mu \mathrm{m}$. Obs: Medidas do mesófilo esponjoso(em vermelho) foram realizadas pelo autor deste trabalho.

Fonte(s): ZANG et al. (14).

Um exemplo que podemos tomar é o trabalho de Zang (14) que elaborou um experimento 
para avaliar a capacidade de adaptação de uma invasora $R$. typhina, cujos exemplares foram examinados após 60 dias sob diversos níveis de luminosidade solar: iluminação plena $(100 \%$ ilimitado); iluminação moderada ( $50 \%$ ou $25 \%$ ) e luminosidade solar baixíssima ( $10 \%$ ou $5 \%$ ). A Figura 2.7, do referido artigo, mostra a plasticidade dessa espécie em resposta à falta de luminosidade para garantir o processo fotossintético.

Embora seja possível notar que a espessura da folha tenha reduzido cerca de $50 \%$, o mesófilo esponjoso apresentou uma variação máxima aproximada de $6 \%$. Se esse comportamento for recorrente em outras espécies vegetais, a caracterização da textura dessa região, pode ser um excelente ponto de partida para uma classificação, e a região do mesófilo paliçádico se torna uma excelente região para a análise da capacidade de plasticidade da planta em resposta às variações de fatores ambientais.

Ainda na Figura 2.7, com base nas imagens dos cortes transversais do citado artigo e da respectiva barra de referência de escala, foi possível obter medidas referenciais das camadas do mesófilo dessas imagens. Foi possível, novamente, notar, conforme observado na imagem da Figura 2.8, a grande variação da espessura do mesófilo paliçádico de $(d)$ para $(e)$ e de $(d)$ para ( f ) respectivamente de $114 \%$ e $131 \%$, enquanto que a variação do mesófilo esponjoso entre as mesmas sequências de cortes foram praticamente iguais a $23 \%$. Essa informação pode ser um diferenciador interessante entre espécies, quando se considera a estabilidade de variação do mesófilo esponjoso, quando comparamos com a variação do mesófilo paliçádico.

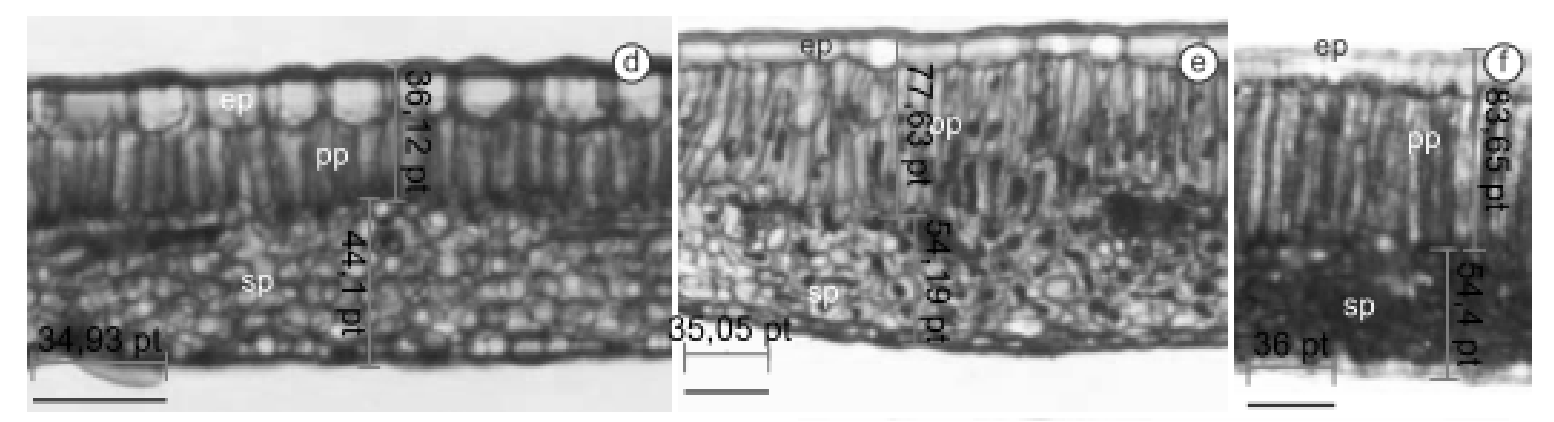

Figura 2.8 - Cortes P. suberosa (d) folha de sombra, (e) folha de sol, (f) folha de sol evidenciando a presença de antocianinas. Medidas realizadas em unidades de pontos(pt) com reescala das barras de (e) e (f) tendo como referência a barra de $(d)$. 


\subsection{Considerações finais}

Neste capítulo foi realizada uma introdução em conceitos de anatomia, ontogenia e a influência ambiental com relação à estrutura foliar. Para isso foram apresentados nas seções função e anatomia foliar, nas quais foram descritos os três principais tecidos que compõem uma folha: sistema dérmico, mesófilo e sistema vascular. Também foi abordado o processo ontogênico foliar, permitindo uma visão geral da atividade meristemática no processo de desenvolvimento foliar, a fim de melhor compreender as relações da influência ambiental, no momento da constituição da estrutura foliar. Por fim, este capítulo tem a intenção de fornecer subsídios teóricos (anatômicos e funcionais) da estrutura foliar, permitindo um melhor entendimento das informações obtidas das imagens espaço-espectrais geradas pelo método desenvolvido. 


\section{CAPÍTULO 3}

\section{Microscopia confocal de varredura à laser por fluorescência em biologia vegetal}

\subsection{Fluorescência e espectros de absorção e emissão}

O fenômeno de fluorescência se inicia quando uma molécula tem seu elétron da camada mais externa transicionado para um nível superior de energia, ao ser excitado pela absorção de um fóton. O retorno desse elétron para seu estado de equilíbrio, se faz pela dissipação dessa energia entre as moléculas (sistema) e pela emissão, ou não, de fótons. Na ausência de emissão, diz-se que houve uma conversão interna completa, isto é, a energia absorvida foi toda dissipada por propagação no sistema e, no caso de emissão de fótons, esta ocorre por fosforescência ou fluorescência $(4,47)$. Neste trabalho somente será tratada a emissão por fluorescência, em função do tipo de microscopia adotada.

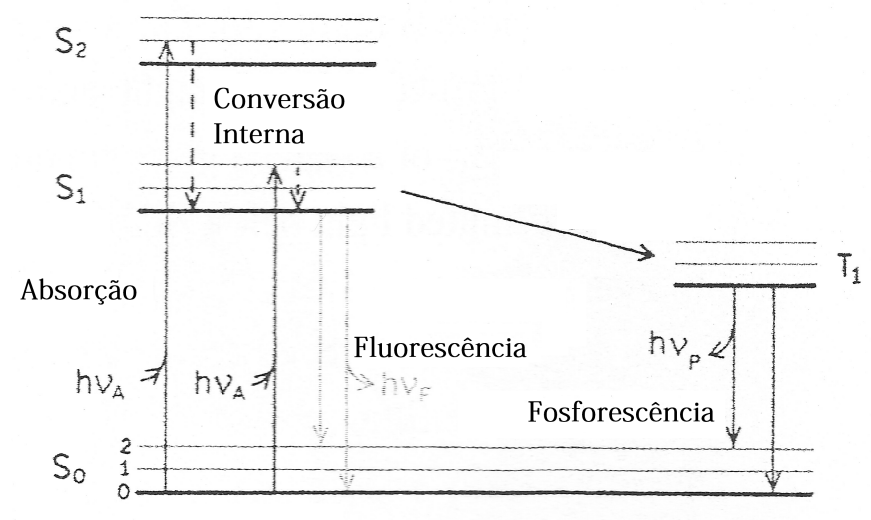

Figura 3.1 - Diagrama de Jablonski, ilustrando a absorção, conversão interna de energia, emissão por fluorescência e emissão por fosforescência. 
A fluorescência é uma maneira pela qual o elétron retorna ao seu estado de equilíbrio, por meio de emissão de luz em um comprimento onda correspondente à energia restante, liberada após a conversão interna(Figura 3.1). Considerando-se que cada composto tem uma configuração distinta de nuvens de elétrons (em função de sua composição química e arranjo molecular), tem-se, consequentemente, a emissão de um conjunto distinto de comprimentos de onda, denominado de espectro de emissão.

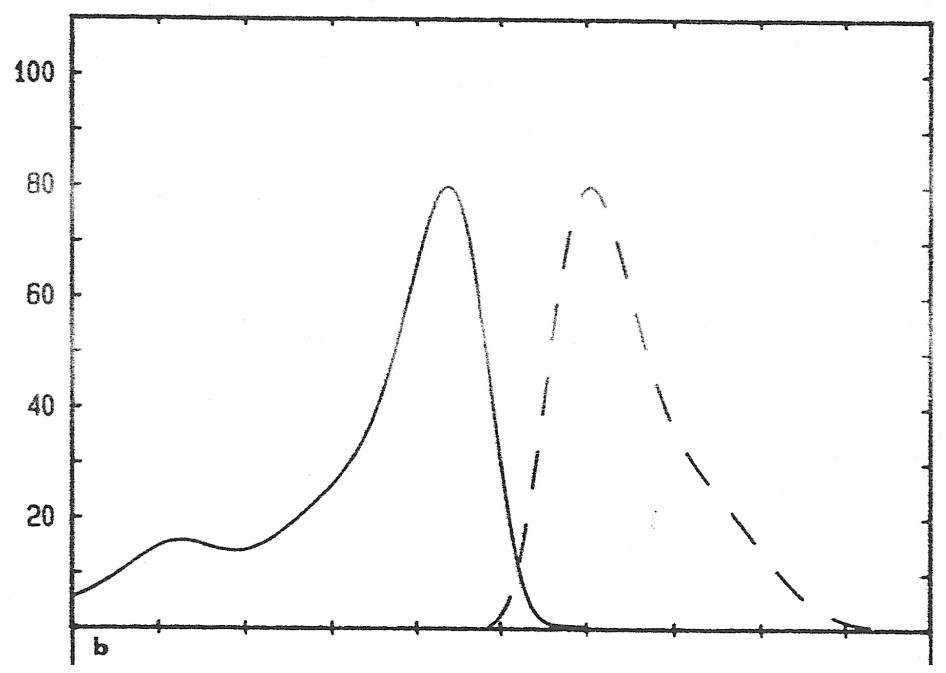

Figura 3.2 - Sobreposição espectral; espectro de absorção traço contínuo; espectro pontilhado espectro de emissão.

Fonte(s): WAMPLER; KUTZ (26).

Além de um espectro de emissão, um composto possui seu espectro de absorção. Este informa o nível de absorção de energia, por comprimento de onda, a fim de se obter a assinatura espectral de emissão de modo eficiente. Para a microscopia confocal de varredura a laser (Confocal Laser Scanning Microscopy - CLSM), o espectro de absorção indica qual é o melhor comprimento de onda que pode ser usado para excitar um composto, que se deseja localizar em uma amostra, em função da resposta dada pela assinatura espectral de emissão. As assinaturas espectrais de emissão, obtidas pela varredura de uma amostra, permitem a construção de imagens multiespectrais em CLSM. Dessa forma, a caracterização de um composto ocorre por dois tipos de assinaturas espectrais: pelo espectro de absorção e pelo espectro de emissão $(4,27)$. Uma característica quanto às assinaturas espectrais de absorção e emissão é que a assinatura de emissão se apresenta quase como uma imagem espelhada do espectro de absorção, com um pequeno deslocamento em direção aos comprimentos de onda relacionados ao vermelho(26)(Figura 3.2 ). Na próxima seção é descrito, de forma básica, o processo de funcionamento de um microscópio de CLSM e a formação da imagem geradas pelos softwares de operação desses equipamentos. 


\subsection{Microscopia confocal de varredura a laser, por fluo- rescência}

O diagrama da Figura 3.3 ilustra um microscópio confocal de varredura a laser, no qual é possível notar alguns elementos que o compõem. Para se entender os princípios e métodos envolvidos na captura e apresentação de imagens multiespectrais, este texto se concentra principalmente nos seguintes componentes: fonte laser, espelho dicroico, unidade de varredura $X Y$, lente objetiva e a unidade fotomultiplicadora.

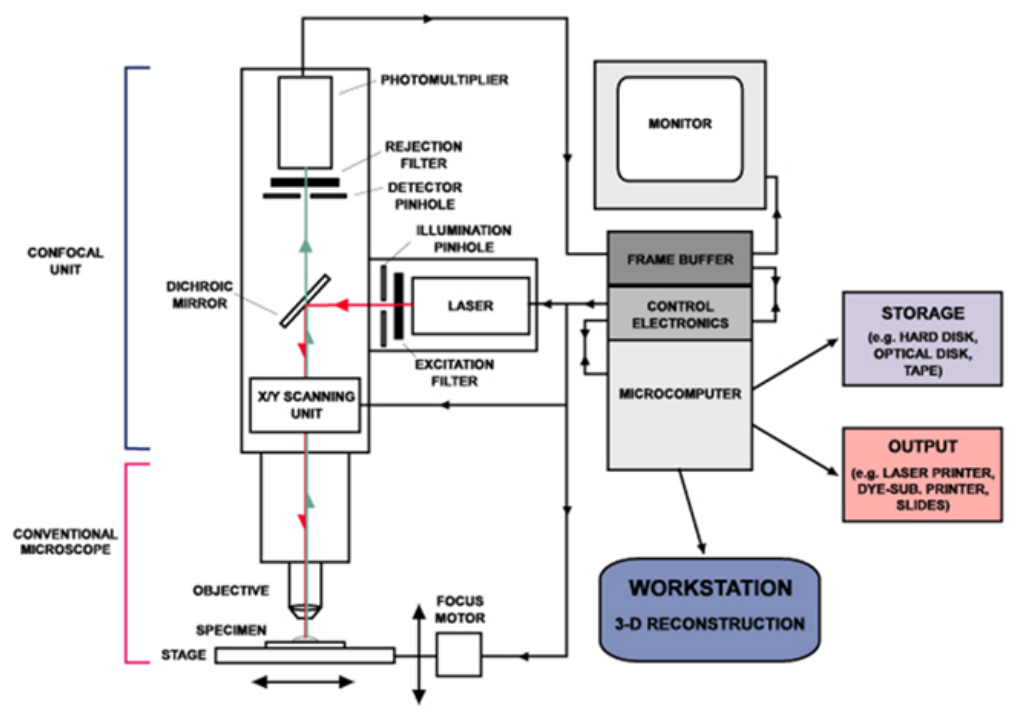

Figura 3.3 - Diagrama esquemático de um microscópio confocal por fluorescência:

(a) controle posicionamento; (b)pin hole fonte; (c) amostra; (d) objetiva; (e) espelho dicróico; (f) filtro; (g) pin hole do detetor; (h)fotomultiplicadora.

Fonte(s): $\operatorname{LSCM}(79)$.

Um princípio da microscopia por fluorescência é maximizar a captura de luz emitida por fluorescência, minimizando a luz de excitação. Dessa forma, a fonte de luz é de extrema importância, pois sua escolha deve estar de acordo com o espectro de absorção da amostra, para que um espectro de emissão seja obtido. Para isso, lasers são utilizados, por sua precisão de comprimento de onda única emitida (luz monocromática) e intensidade estável.

Uma vez emitido um pulso de laser, esse é desviado por um espelho dicróico para a unidade de controle de varredura $X Y$, que o redireciona, passando pela lente objetiva, para uma coordenada específica na amostra(vetor em vermelho na Figura 3.3). O papel da unidade de controle de varredura $X Y$ é de varrer a amostra, ponto-a-ponto, linha-a-linha. A Figura 3.4 mostra, à esquerda, o interior de uma unidade de varredura a laser e, à direita, como o feixe de laser se comporta nesse processo de varredura da amostra, ao sair da objetiva. 
O pulso de laser ao atingir a amostra, provoca a resposta desta, com a emissão de luz por fluorescência. Essa emissão faz o caminho inverso do laser, voltando pela objetiva, passando pelo espelho dicróico e seguindo em direção à fotomultiplicadora - conforme indica vetor cinza na Figura 3.3.
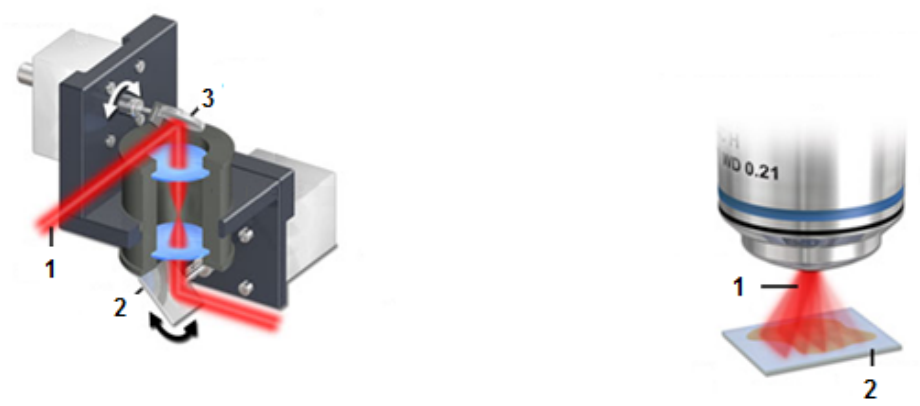

Figura 3.4 - Esquerda: unidade de varredura $X Y$ : (1) feixe laser; (2) espelho de varredura em X; (3) espelho de varredura em Y. Direira: movimento de varredura do feixe de laser passando pela objetiva: (1) feixe laser; (2) amostra.

Fonte(s): esq. CONFOCAL (80); dir. RESONANT (85).

Fotomultiplicadoras são detectores de fótons muito utilizados pela precisão de medida e excelente característica de amplificação do sinal recebido(26). São baseados em um tubo(Figura 3.5-esquerda), que utiliza em sua estrutura, um catodo como um detector de fótons(fotocatodos), e emitem elétrons em resposta à absorção de luz. Esses elétrons são acelerados por um campo elétrico, para um emissor secundário (segundo fotocatodo) chamado de dynode. O processo de amplificação ocorre com as sucessivas passagens pelos dynodes, gerando mais e mais elétrons com ganhos cada vez maiores, para que possam ser mensuráveis $(4,26)$. A capacidade de captura simultânea de comprimentos de onda de um microscópio confocal está relacionada ao número de sensores da fotomultiplicadora utilizada.
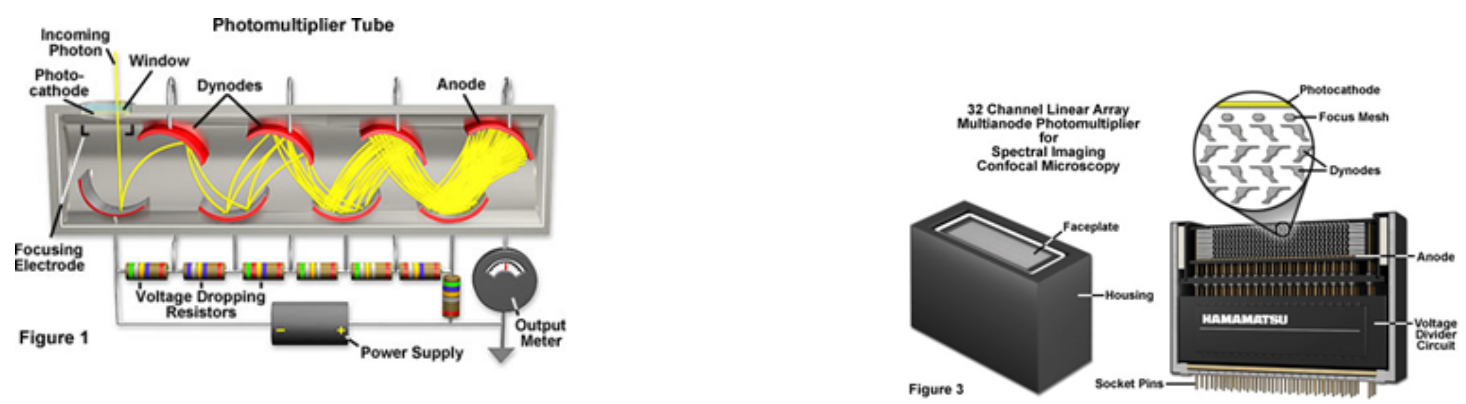

Figura 3.5 - Esquerda: diagrama de uma fotomultiplicadora de um canal. Direita: fotomultiplicadora linear de 32 canais. 
A Figura 3.5-direita ilustra uma fotomultiplicadora linear com a capacidade de leitura de 32 comprimentos de onda distintos. O processo de detecção do espectro emitido é fundamental para a captura e formação da imagem multiespectral. A formação da imagem multiespectral é feita pelo armazenamento, em frame-buffer, de cada assinatura espectral de emissão, coletada ponto-a-ponto e ordenada pela respectiva coordenada de varredura do feixe de excitação(Figura 3.6-esquerda), o qual é controlado pela unidade de varredura XY. Basicamente, o frame-buffer pode ser visto como uma matriz de memória de dimensões $(M x N x C)$, em que $(M x N)$ correspondem ao comprimento e largura da amostra, e $C$ à profundidade dessa matriz que armazena as intensidades dos $C$ comprimentos de onda, lidos simultaneamente pela fotomultiplicadora.
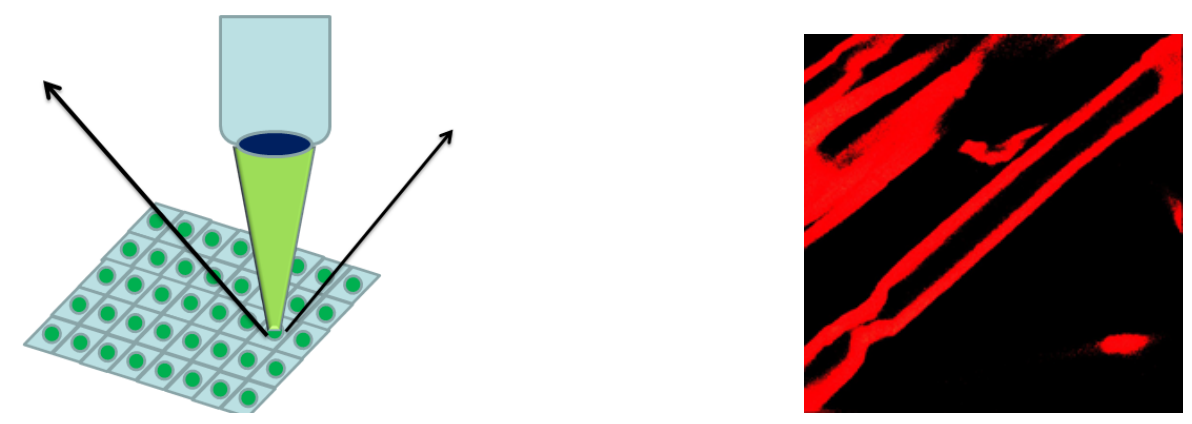

Figura 3.6 - esquerda: Ilustração do processo de varredura pontual; direita: Imagem de corte confocal de fibras vegetais.

Fonte(s): Francisco E. G. Guimarães *

Nota-se que o processo descrito foge da captura convencional de imagem por $\mathrm{CCD}^{\dagger}$ que, embora forneça a posição relativa do sinal na amostra, não possui alto ganho na amplificação deste, além de ser suscetível a ruídos, quando comparado com fotomultiplicadoras $(6,25,26)$. Outra característica importante do CCD diz respeito à resolução de captura, que é diretamente dependente da densidade de elementos por área do dispositivo e de seu respectivo tamanho - que o torna uma opção nada interessante quando se deseja alta resolução em imagens de microscopia confocal $(4,23,26)$.

Na microscopia confocal, o que permite a obtenção de uma imagem "limpa", e um alto ganho na resolução, é o fato da fonte de iluminação alinhar-se com o ponto focal de forma eficiente(6 apud 7), permitindo um "corte" (Figura 3.6-direita) na amostra em um mesmo plano focal, bloqueando a interferência de emissões que estejam fora desse plano e volume

*Imagens gentilmente cedidas por Francisco E. G. Guimarães.

${ }^{\dagger}$ CCD ou Charge-Coupled Device - um arranjo de elementos compostos por um semicondutor, dióxido de silício $\left(\mathrm{SiO}_{2}\right)$, que armazenam cargas, induzidas por fótons. A leitura de uma imagem projetada em sua superfície é feita por meio de um registrador serial, para o qual são transferidas as cargas linha-a-linha paralelamente. Essas cargas por linha são quantificadas correspondendo à intensidade do respectivo elemento do $\operatorname{CCD}(23,26)$. 
ótico. Como a captura ocorre de forma pontual(Figura 3.6-esquerda), o processo de varredura da amostra gera uma quantidade de pixels multiespectrais na ordem de $10^{6}$ pixels por imagem, o que torna as informações espectrais obtidas, uma boa base para análises estatísticas.

\subsection{Visualização de imagens multiespectrais por softwa- res proprietários e implicações}

Uma vez obtida a imagem multiespectral, essa é apresentada de duas maneiras: imagens individuais de cada canal espectral ou em uma única imagem obtida pela cor resultante da assinatura espectral de cada pixel multiespectral, convertida para o espaço de cores RGB.

A Figura 3.7 mostra imagens desses dois casos, geradas pelo software proprietário do microscópio confocal. Nesses dois tipos de apresentação, surgem problemas decorrentes dessa metodologia de criação de imagens, que são apontados e fundamentados nesta seção, pela descrição do sistema visual humano e pelo processo de transformação de sistemas de cores. Mais informações sobre o processo de percepção espectral humano e a transformação de espaço de cores para o sistema CIE RGB, são melhor tratadas no capítulo seguinte.
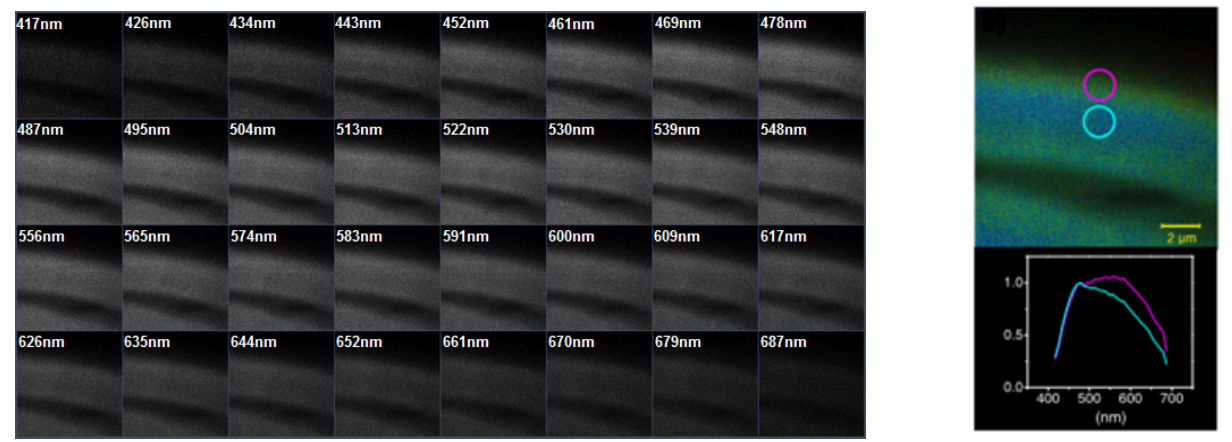

Figura 3.7 - Esquerda:Imagem multiespectral composta por 32 canais com seu respectivo comprimento de onda impresso no canto superior esquerdo. Direita: Síntese dos 32 canais da imagem anterior para sistema de cores RGB, realizado pelo software proprietário do equipamento.

Fonte(s): esq. Elaborada pelo autor; dir. COLLETA et al. (71).

O grupo de imagens da Figura 3.7 -esquerda mostra nitidamente a captura multiespectral em 32 canais. Cada canal foi capturado com uma intensidade de 16 bits por pixel, permitindo uma variação de 65.536 tons de cinza (correspondente à $2^{16 b i t s}$ ), por pixel/canal. Isto é, se considerarmos que um único pixel multiespectral é composto por seus 32 canais, tem-se a possibilidade de variações espectrais na ordem de $1,34.10^{154}$ espectros - número correspondente à $2^{512 b i t s}$ por pixel (sendo $512=32 * 16$ ). Embora seja possível notar qual canal tem maior predominância na amostra, observando-se as intensidades de tons de cinza de cada canal, 
essa forma de visualização não permite avaliar a variação espectral em cada pixel da imagem multiespectral.

A segunda opção(metodologia) de visualização (imagem colorida da Figura 3.7 - direita) representa o que seria o resultado da percepção, pela visão humana, das assinaturas espectrais de cada pixel, representadas no espaço de cores CIE RGB. Esse formato, embora não preserve a informação espectral, é utilizado para orientar o pesquisador na seleção de regiões de interesse, conforme indicado pelas circunferências vermelha e azul. Com base nessas regiões, o software proprietário do microscópio acessa a matriz espectral e extrai os espectros médios de cada região. Isso pode ser constatado no gráfico espectral, localizado logo abaixo da imagem colorida da amostra. As assinaturas em vermelho e azul correspondem às áreas de seleção de mesma cor. Este tipo de metodologia de apresentação de imagens multiespectrais, adotada por todos os equipamentos de microscopia confocal, apresenta algumas falhas que comprometem a análise de amostras. Assim, algumas pontos serão levantados e discutidos.

Primeiramente, deve-se notar que a principal informação para o pesquisador, no uso da microscopia confocal, é a assinatura espectral. Outra informação relevante é a localização dessa assinatura, no espaço da imagem. A combinação, assinatura espectral e sua posição relativa na amostra, fornece informações químicas e estruturais da amostra, que são importantes para o estudo e caracterização do objeto em estudo.

Pela segunda metodologia (a qual é adotada pelos softwares proprietários de microscópios confocais) descrita em parágrafo anterior, a obtenção da assinatura espectral de uma amostra é comprometida por três principais fatores: pela própria representação da imagem multiespectral por uma imagem no espaço de cores CIE RGB; pela seleção manual de uma região de interesse e pela forma de obtenção do espectro da região selecionada.

A representação de uma imagem multiespectral, por uma imagem no sistema de cor CIE RGB interfere no processo de análise, por uma simples razão: a cor é uma experiência pessoal resultante de um processo fisiológico. Por isso, a capacidade de percepção de cores e suas nuances, realizada pelo sistema visual humano, é individual e suscetível à interferência de textura, brilho e contraste da imagem. Isso ocorre principalmente nos casos em que se têm assinaturas espectrais distintas, mas com pequenos deslocamentos espectrais. Nessa situação, há uma alta probabilidade desses espectros serem representados por uma mesma cor, ou por nuances de uma cor, imperceptíveis para o observador(principalmente pela redução do vetor espectral de dimensão 32 para um vetor de dimensão 3 - CIE RGB). 

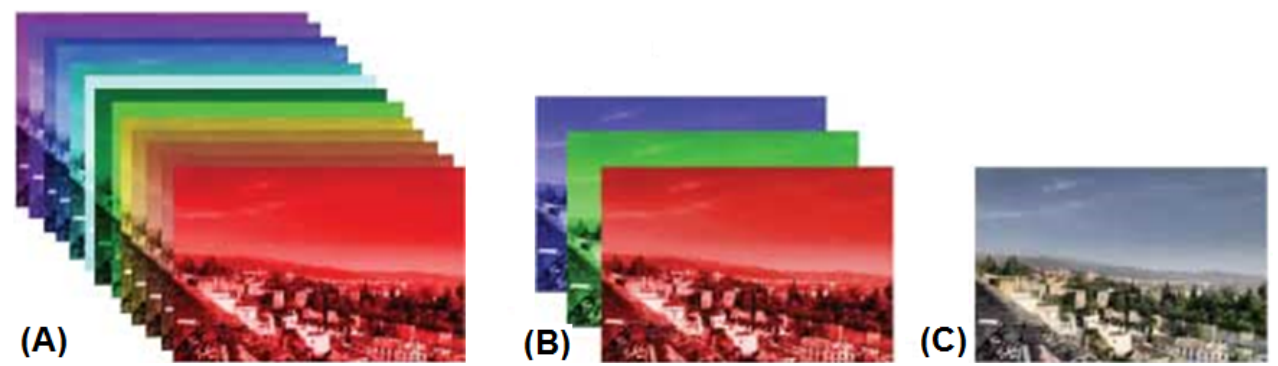

Figura 3.8 - $\quad$ exemplos de: (a)representação de uma imagem multiespectral de 32 canais capturados, entre 400nm a 700nm; (b) redução da dimensionalidade para três canais - RGB; (c) síntese da imagem apresentada no monitor.

Fonte(s): LASER (81)

A Figura 3.8 ilustra essa transformação de dimensionalidade: considerando a Figura 3.8-A, que representa uma imagem multiespectral de 32 canais, um único pixel multiespectral tem a capacidade de representar variações espectrais na ordem de $1,34.10^{154}$ espectros, conforme foi calculado anteriormente. Por outro lado, o CIE RGB(Figura $3.8-\mathrm{B}$ ), por trabalhar com 3 canais de 8 bits cada, permite que cada pixel RGB represente um total de $2^{24 b i t s}(24=$ 8 bits $* 3$ canais $)$, ou $1,68.10^{7}$ cores. Em termos percentuais, um pixel CIE RGB representa apenas $1,25.10^{-145 \%}$ (Figura 3.8-C) da informação de um pixel multiespectral, caso a visão humana fosse capaz de identificar 16 milhões de cores, o que está muito longe da realidade. Para se ter ideia da perda de informação, se tomada a razão entre todas as possibilidades de representação de espectros de um pixel multiespectral (de 32 canais por 16bits por canal), pelo número máximo de cores que podem ser representadas por um pixel, no sistema de cores $\mathrm{CIE}$ RGB, tem-se que uma única cor representa $8.10^{146}$ espectros distintos . Logo, é nítido que o uso de cores para representar assinaturas multiespectrais causa ao pesquisador uma grande interferência na detecção e seleção das regiões de interesse.

Outra interferência identificada no processo de caracterização espectral da amostra é a seleção manual de regiões. O parágrafo anterior já explicou a interferência da cor na seleção de uma região de interesse. Entretanto, a questão agora se concentra na extensão da área selecionada. Não há uma regra ou método que defina a extensão necessária para a extração do espectro médio de uma região. Sabe-se que a quanto maior a área de seleção, mais próximo de uma assinatura global da amostra se chega - o que não é interessante, pois, na maioria das vezes, deseja-se verificar variações químicas e estruturais, obtidas por assinaturas locais. Assim, a seleção manual de regiões pode forçar a obtenção de uma assinatura média de estruturas que sutilmente se divergem mas, por estarem fisicamente próximas, como em uma região de fronteira de estruturas, são vistas como tendo a mesma composição química. 
Por fim, a própria obtenção da assinatura espectral da região de interesse, que é feito por uma média, é outro fator que influencia negativamente o processo de análise da amostra, principalmente por considerar a vizinhança espacial como critério.

\subsection{Considerações finais}

Este capítulo teve como objetivo apresentar conceitos básicos sobre espectroscopia por fluorescência, necessários para expor e discutir o impacto do processo de representação de imagens multiespectrais pelo sistema de cores CIE RGB. Foi demonstrado, de forma quantitativa, o grau da perda de informação e, consequentemente, o comprometimento da análise dos dados multiespectrais, pelo método de representação das imagens multiespectrais e cálculo do espectro médio por região, adotado pelos softwares proprietários dos microscópios confocais de varredura a laser por fluorescência.

Assim, na primeira seção, introduziram-se os conceitos básicos envolvidos no fenômeno da fluorescência e seu uso na caracterização de compostos pelos respectivos espectros de absorção e emissão. A segunda seção descreveu o funcionamento básico de um microscópio confocal de varredura a laser por fluorescência e seu método de captura de imagens multiespectrais. A terceira seção apresentou e discutiu os efeitos de perda de informação na representação de imagens multiespectrais pelo sistema CIE RGB e a respectiva influência na caracterização de uma amostra pela seleção de regiões para obtenção de suas respectivas assinaturas espectrais.

No Capítulo 4 são apresentados métodos e conceitos de manipulação de imagens multiespectrais que foram utilizados no desenvolvimento do método de visualização espaço-espectral (apresentado no Capítulo 5), solução desenvolvida e proposta neste trabalho e que soluciona os problemas apontados neste capítulo. 


\section{CAPÍTULO 4 \\ Imagens multiespectrais e métodos de processamento}

\subsection{Imagens multiespectrais}

Uma imagem multiespectral é aquela composta por muitas bandas, cada qual informando a intensidade de seu respectivo comprimento de onda, por meio da intensidade de seus pixels(15).

Ao observarmos uma dessas bandas, sua respectiva imagem terá a aparência de uma imagem em tons de cinza. Um exemplo grosseiro de uma imagem multiespectral bastante difundido são as imagens digitais RGB, compostas pelas camadas R(vermelho), G(verde) e $\mathrm{B}(\mathrm{azul})$. Nessas, cada pixel é um vetor espectral, contendo as intensidades de cada uma das bandas que compõem a imagem.

Alguns autores usam a denominação imagem multiespectral quando o número de bandas é inferior a uma centena e de hiper-espectrais quando este número é ultrapassado (15). Embora não haja um número bem estabelecido relativo ao quantitativo de bandas para uso de tal definição, notou-se que o primeiro é bastante usado em publicações ligadas à espectroscopia $(28,29,48,49,51,54-57,58,61,63,68,69)$, enquanto o segundo é encontrado em publicações relacionadas à área de sensoriamento remoto(30, 52, 59, 60, 62, $65-67)$.

Independente da denominação dada, ou à quantidade de bandas envolvidas, os problemas relacionados ao processamento dessa são os mesmos - deve-se considerar que quanto maior o número de bandas, maior é o custo computacional em termos de uso de memória e processamento - embora isso não defina ou altere o método utilizado na solução dos problemas envolvidos no processamento de imagens multiespectrais. Assim, para que se evitem possíveis confusões, neste trabalho será utilizado somente o termo multiespectral.

Quatro problemas são considerados especiais no processamento de imagens multiespectrais(15): substituição de bandas por outras que são descorrelacionadas(31, 50); identificação de um ob- 
jeto representado pela assinatura espectral de um pixel no caso de espectros compostos $(38-$ 40, 42 - 46); representação de uma imagem multiespectral em três bandas no sistema de cores RGB e, por último(41), a manipulação de pixels de imagens multiespectrais $(20-22,64,70)$ (Figura 4.1).

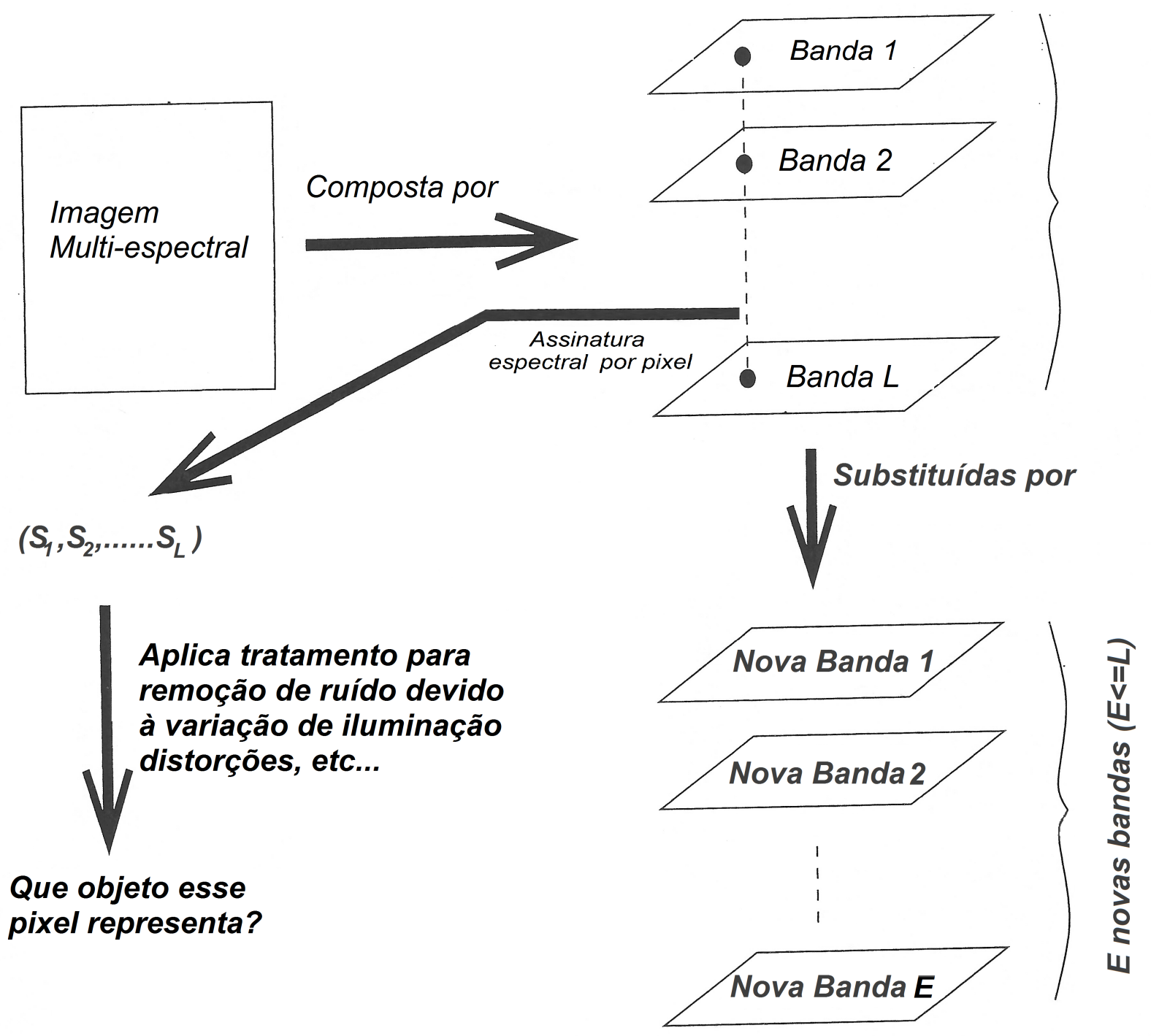

Figura 4.1-Principais problemas no processamento de imagens multiespectrais.

Fonte(s): PETROU; PETROU (15).

\subsection{Substituição de bandas por outras descorrelacionadas}

A substituição de bandas por outras que são descorrelacionadas é particularmente importante no caso de imagem de sensoriamento remoto, ou quando se deseja criar uma banda única e representada $(15,31)$ em tons de cinza. 
A motivação para se obter imagens em tons de cinza decorre do fato de que a maioria das técnicas de processamento de imagem são aplicáveis somente em imagens em tons de cinza. Um método muito simples para a construção de uma imagem em tons de cinza, a partir de uma imagem multiespectral, pode ser realizado com base na média espectral das bandas $L$ de cada pixel(15).

$$
\bar{p}(x, y)=\frac{1}{L} \sum_{l=1}^{L} p(x, y, l)
$$

Embora comumente utilizadas, imagens em tons de cinza não carregam o máximo de informação de uma imagem multiespectral(15). Assim, é desejável que, em uma única banda, seja agrupado o máximo de informação possível. Para isso, uma técnica bastante utilizada é a transformada de Karhunoen-Loeve ou PCA (principal component analysis)(15).

A vantagem dessa transformada está na projeção das bandas em um outro espaço de coordenadas, tal que as projeções dessas bandas tenham menor índice de correlação, tornando possível selecionar a banda que contém o máximo de informação, identificada por possuir o menor índice de correlação em relação às demais bandas(15).

A seleção de bandas descorrelacionadas tem o objetivo de descartar informações redundantes, a fim de diminuir a dimensionalidade de um pixel-vetor ( pela redução número de bandas).

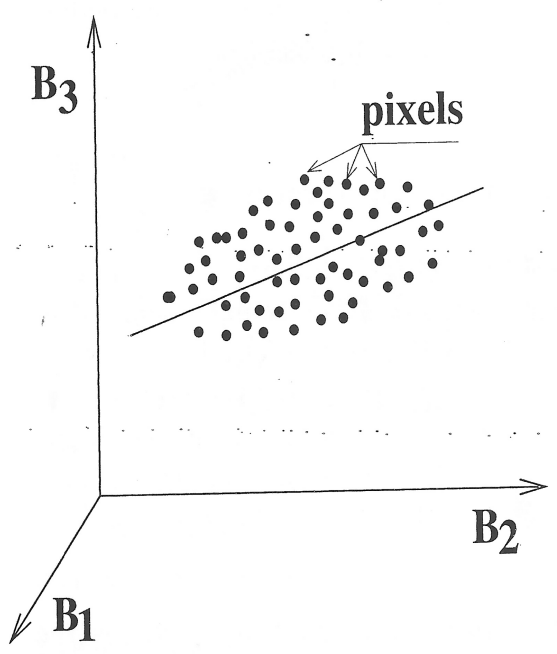

(a)

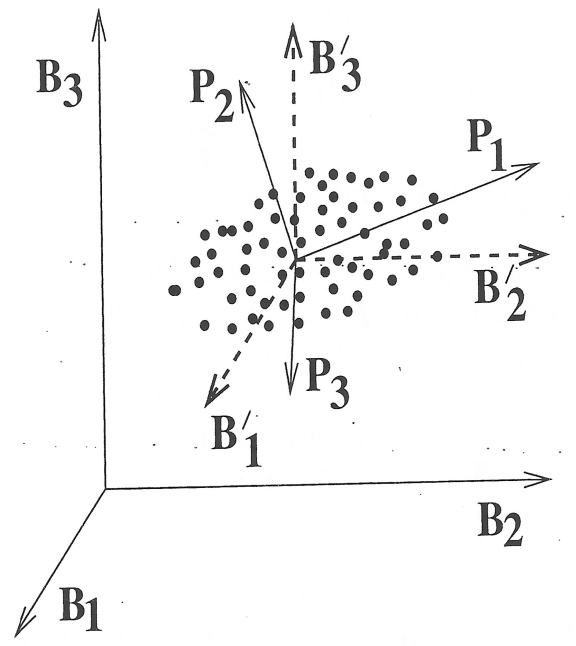

(b)

Figura 4.2 - Diagrama representando a nuvem de pixel antes da tranformada PCA (esq.) e depois da aplicação da transformada(dir). 
Se considerarmos uma imagem multiespectral composta por 3 bandas e o gráfico dos pixels em um espaço 3D, a posição de cada pixel em um sistema de vetores tridimensional pode ser observado como uma nuvem(Figura 4.2). A transformada de PCA definirá um novo sistema de coordenadas tal que as componentes do sistema tenham a máxima descorrelação(15).

Entretanto, uma desvantagem apresentada pelo uso deste método é sua não correspondência física a nenhuma banda, o que impossibilita seu uso para se obter qualquer informação espectral.

\subsection{Mistura espectral}

Um problema recorrente no processamento de imagens espectrais, normalmente citado na literatura, é o "spectral ummixing problem" - (problema de decomposição espectral), isto é, a separação dos componentes de uma assinatura espectral que carrega em si a informação de duas (ou mais) substâncias, interferindo na precisão e identificação de um objeto contido na imagem multiespectral (15). Essa "mistura" de assinaturas ocorre no momento da aquisição da imagem multiespectral e está relacionada à resolução do sensor de captura. Quanto menor a resolução de captura desse sensor, maior a chance de que ocorra a composição de assinaturas espectrais na captura(15).

Um exemplo simples para entender a questão é colocado por Pretou e Petrou(15). Se em um pixel que corresponde a uma área de $2 x 2$ metros, são capturados concreto e árvore, a assinatura espectral correspondente será a composição das assinaturas espectrais desses dois elementos. Esse mesmo conceito pode ser expandido para uma escala nanométrica, em que os objetos são moléculas ou agregados de moléculas distintas, cujo espectro resultante, na aquisição da imagem multiespectral, é uma mistura da assinatura espectral desses.

Um caminho adotado para a separação dessas assinaturas espectrais é a construção de modelos lineares com base na combinação de um conjunto de possíveis espectros $K=\left\{k_{1} \ldots k_{n}\right\}$ - que implica em um conhecimento a priori. Partindo-se desse conjunto de espectros, tentase estabelecer o peso de participação de cada um, por meio de um conjunto de escalares $A=\left\{a_{1} \ldots a_{n}\right\}$ assim, a composição de um pixel multiespectral é definido por:

$$
S p=\sum_{n=1}^{N} a_{n} k_{n}+\epsilon_{n} \quad \text { sendo } \quad \sum_{n=1}^{N} a_{n}=1
$$

sendo $\epsilon_{n}$ o erro residual do modelo linear e $a_{n}$ a fração correspondente ao espectro $k_{n}$. 
Deve-se observar que $S p$ é a assinatura espectral de um único pixel. Assim, considerandose que uma imagem espectral tem dimensões $M x N$, haverá então $M . N$ equações (que é o total de pixels).

Se $a_{n}$ for o mesmo para todas as bandas, $L$ o número de bandas e $K$ os espectros possíveis, o sistema contendo as $M . N$ equações somente poderá ser resolvida, desde que $K \leq L(15,32-37)$.

\subsection{Visão, espectros e cores}

Entender o fenômeno de visão e a percepção de cores implica em entender o sistema visual humano $(19,24)$. Os olhos contêm, em sua retina, neurônios especializados conhecidos como cones e bastonetes. Os bastonetes possuem uma grande sensibilidade à luz e uma rápida capacidade de percepção visual, sendo responsáveis pela visão periférica e visão noturna, embora não sejam sensíveis a cores. Os cones, em menor quantidade, têm baixa sensibilidade à luz e são responsáveis pela acuidade visual e percepção de cores.

\subsubsection{Visão e Espectros}

A cor é uma sensação subjetiva, resultante da percepção de ondas eletromagnéticas. Essa sensação ocorre devido a três tipos de cones, que se especializaram na percepção de ondas eletromagnéticas entre a faixa de $400 \mathrm{~nm}$ a $700 \mathrm{~nm}$ - o chamado espectro de luz visível. Esse é um processo complexo que envolve a resposta dos cones dos tipos $S, M$ e $L$; os quais erroneamente são denominadas de cones azul, verde e vermelho $(4,15,19,24)$.

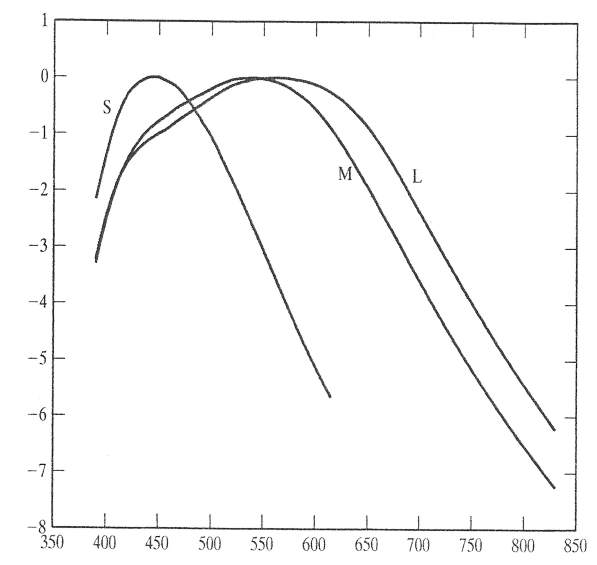

Figura 4.3-Curvas de sensibilidade dos cones $\mathrm{S}, \mathrm{M}$ e $\mathrm{L}$ por comprimento de onda. 
Esses três cones respondem à maioria dos comprimentos de onda sendo, entretanto, mais sensíveis a faixas de comprimentos de ondas específicas. O gráfico da Figura 4.3 mostra a magnitude da sensibilidade dos cones dos tipos $S, M$ e $L$ por comprimento de onda. Esse fato é a base para a teoria da tricromia, a qual afirma que qualquer cor (comprimentos de luz monocromática) pode ser obtida a partir da "mistura" ou soma, de três cores primárias, mudando-se simplesmente a intensidade de cada um desses comprimento de onda(24).

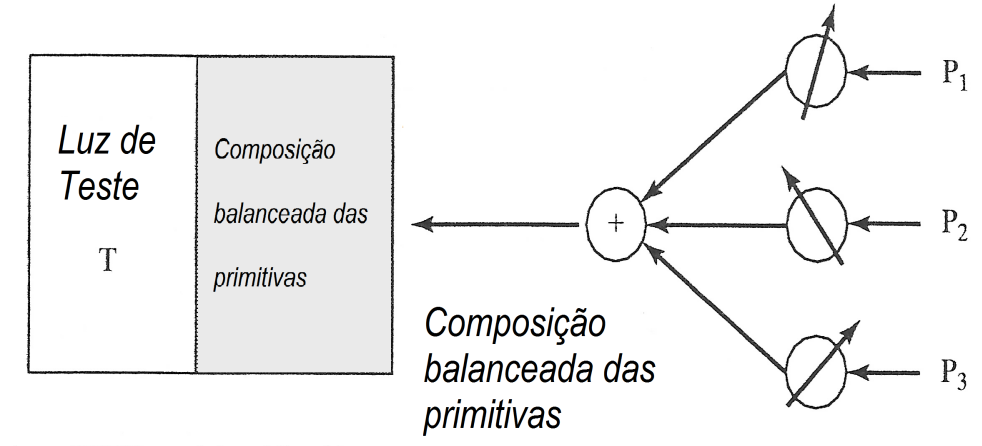

Figura 4.4 - Método experimental para obtenção de uma cor com base em três feixes de luzes monocromáticos. $\mathrm{O} \mathrm{CIE}$ definiu uma tabela de pesos W1, W2 e W3 para uma comprimentos de onda indo de $380 \mathrm{~nm}$ a 770nm, denominada de CIE RGB 1934.

Fonte(s): FORSYTH; PONCE (24).

\subsubsection{Sistemas de cores}

O fenômeno de tricromia tem como base a forma que a cor é entendida no interior dos olhos, pois, conforme anteriormente dito, o fenômeno é explicado assumindo-se que, na região da retina, chamada de fóvea, há receptores distintos de luz, que realizam a percepção das cores de forma invariante; isto é, eles reagem de maneira forte ou fraca, mas não indicam o comprimento de onda que os estimulam $(15,24)$.

Assim, dois tipos de luzes seriam semelhantes se elas produzissem as mesmas respostas nos receptores, independente de sua intensidade espectral(Figura 4.4), - o que permite obter um modelo que gere uma reação humana para luz:

$$
p_{k}=\int_{\Lambda} \delta_{k}(\lambda) \cdot E(\lambda) d \lambda
$$

sendo $p_{k}$ resposta para o k-ésimo tipo de receptor, $\delta_{k}(\lambda)$ por sua sensibilidade; $E_{\lambda}$ a luz que chega ao receptor e; $\Lambda$ a faixa de comprimento de ondas visíveis(24).

Entendido o processo de percepção de cores a partir do fenômeno de tricromia torna-se 
importante a utilização de um processo que descreva as cores de forma precisa e padronizada. Assim, para a representação e descrição das cores usa-se um espaço linear de cores com base em um conjunto de primitivas e pesos de contribuição de cada primitiva. O resultado obtido é comparado com a cor que se deseja obter (Figura 4.4 ).

Com base em três fontes primárias de luz, sistemas de cores foram constituídos(53). Os sistemas de cores mais comuns são CIE RGB, CIE XYZ - recentemente o CIE sRGB.

\subsubsection{Sistema CIE RGB}

Este sistema usa como espectros primários as cores monocromáticas com comprimentos de onda em: $435.8 \mathrm{~nm}, 546 \mathrm{~nm}$ e $700 \mathrm{~nm}$. É a combinação desses espectros em intensidades distintas que permite emular várias cores, inclusive o branco ideal - neste caso, como se deseja o branco ideal, para ter energia constante em todos comprimentos de onda, normalizam-se as curvas ( Figura 4.5 ).
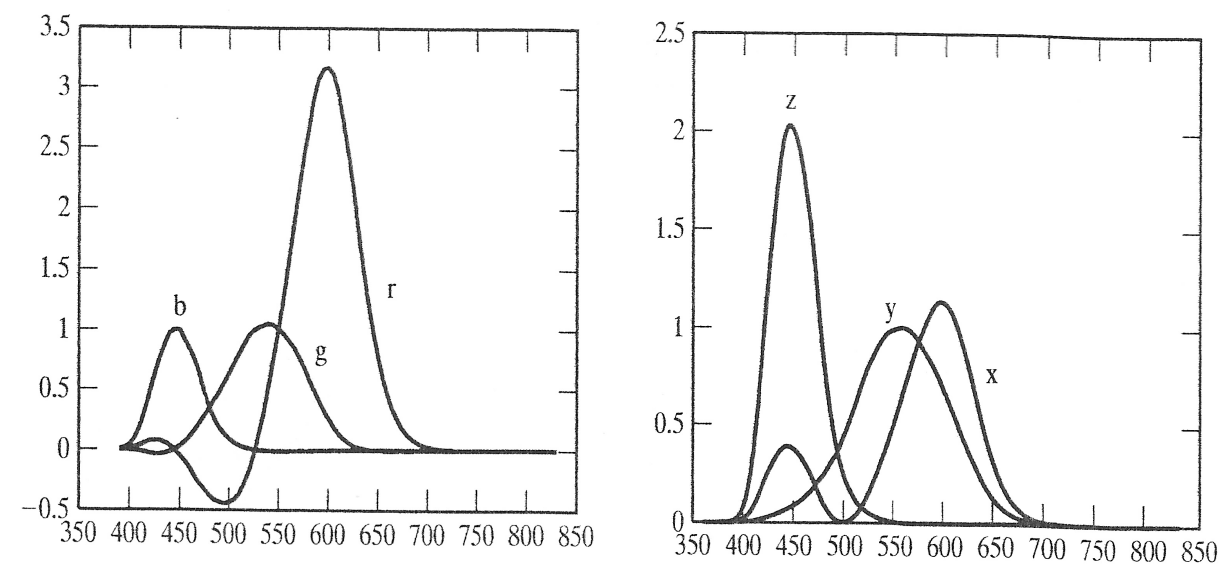

Figura 4.5-Espectro de resposta do sistema de cores RGB (esq.) e do sistema XYZ (dir.).

Fonte(s): FORSYTH; PONCE (24).

\subsubsection{Sistema CIE XYZ}

É um padrão bastante popular. Todos os valores são positivos ao contrário do CIE RGB - cujo espaço aceita valores negativos (Figura 4.5). Não é possível obter CIE XYZ primário porque para alguns comprimentos de onda o valor da radiância é negativa. Entretanto, dadas somente as funções de combinação de cores, pode-se especificar um sistema de coordenadas XYZ normalizado de cor e então descrevê-la $(1,15,24)$ baseado em uma transformação aplicada ao sistema CIE RGB, cujos valores dos parâmetros não são negativos. Esse sistema tem como 
base um sistema cartesiano no espaço 3D sendo que cada eixo representa uma das componentes primárias.

Baseado no sistema de tri-estímulos com valores de $T_{1}, T_{2}, T_{3}$ máximos, pode-se obter um sistema de cor representado em um espaço 3D definido por:

$$
t_{j}=\frac{T_{j}}{T_{1}+T_{2}+T_{3}} j=1,2,3
$$

o que resulta em um sistema normalizado de eixos unitários. O plano que corta esse sistema de coordenadas é chamado de triângulo de cores de Maxwell (15).

Espaços lineares de cores permitem um grande número de construções de gráficos úteis que seriam mais difíceis de se fazer em um sistema 3D. Assim, é comum criar um espaço 2D com base no plano de intersecção XYZ ( Figura 4.6 )- obtendo-se o espaço CIE XY.

$$
(x, y)=\left(\frac{X}{X+Y+Z}, \frac{Y}{X+Y+Z}\right)
$$

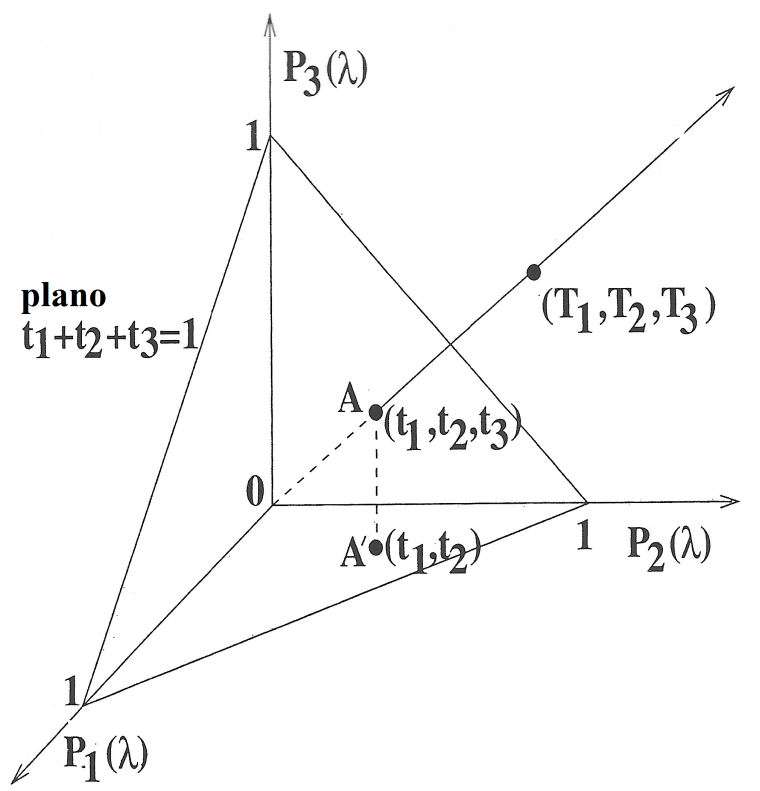

Figura 4.6-Sistema de cores CIE XYZ e o plano de intensidade máxima.

Fonte(s): FORSYTH; PONCE (24).

O brilho aumenta sua intensidade ao longo da diagonal principal, sendo possível separá-la e representar uma cor com intensidade invariante, considerando-se o plano triangular formado(24).

O estímulo normalizado é dado por $t_{i}=\frac{t_{i}}{T_{1}+T_{2}+T_{3}}$, sendo $t_{1}+t_{2}+t_{3}=1$, que colapsa 
em um plano. Assim, em um sistema 2D, é possível representar uma cor invariante ao briIho. Qualquer ponto nesse plano pode ser definido por 2 números criando-se um sistema de coordenadas, definido como diagrama de cromaticidade(Figura 4.7).
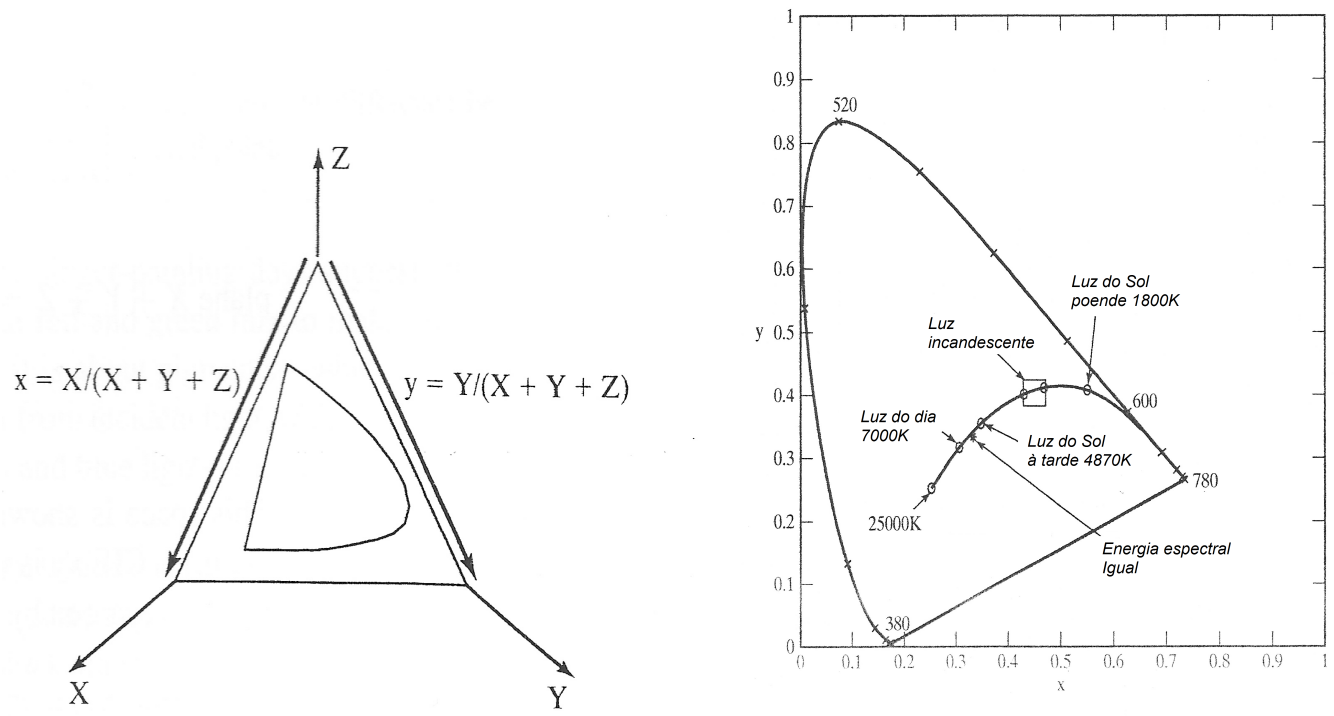

Figura 4.7 - Transformação linear do espaço CIE XYZ (esq.) para o espaço de coordenadas CIExy; Diagrama cromático obtido do CIExy(dir.).

Fonte(s): FORSYTH; PONCE (24).

\subsection{Processamento}

O objetivo desta seção é a de apresentar as técnicas utilizadas neste trabalho para a construção do método desenvolvido. Embora tenham como objeto de aplicação imagens em tons de cinza, seu uso em imagens multiespectrais é direto quando aplicadas em uma banda ou um vetor por vez.

\subsubsection{Processamento baseado no histograma}

Uma imagem pode ser definida como uma função $f(x, y)$ em que temos para cada elemento da imagem (pixel) um valor associado $f(x, y)=\{0 \leq f(x, y) \leq T \mid 1 \leq x \leq M, 0 \leq y \leq N\}$ sendo $T$ o valor máximo de intensidade - 255 em imagens em tons de cinza.

O histograma de tons de cinza é uma característica global, de primeira ordem, que se pode obter de uma imagem, pois mostra a frequência de ocorrência de pixels de mesmo valor de intensidade (que normalmente fica entre 0-255), por meio de um gráfico $(4,24)$. Por meio desse recurso, é possível observar algumas características da imagem e aplicar algumas 
transformações para enfatizar características ou mesmo aplicar transformações.
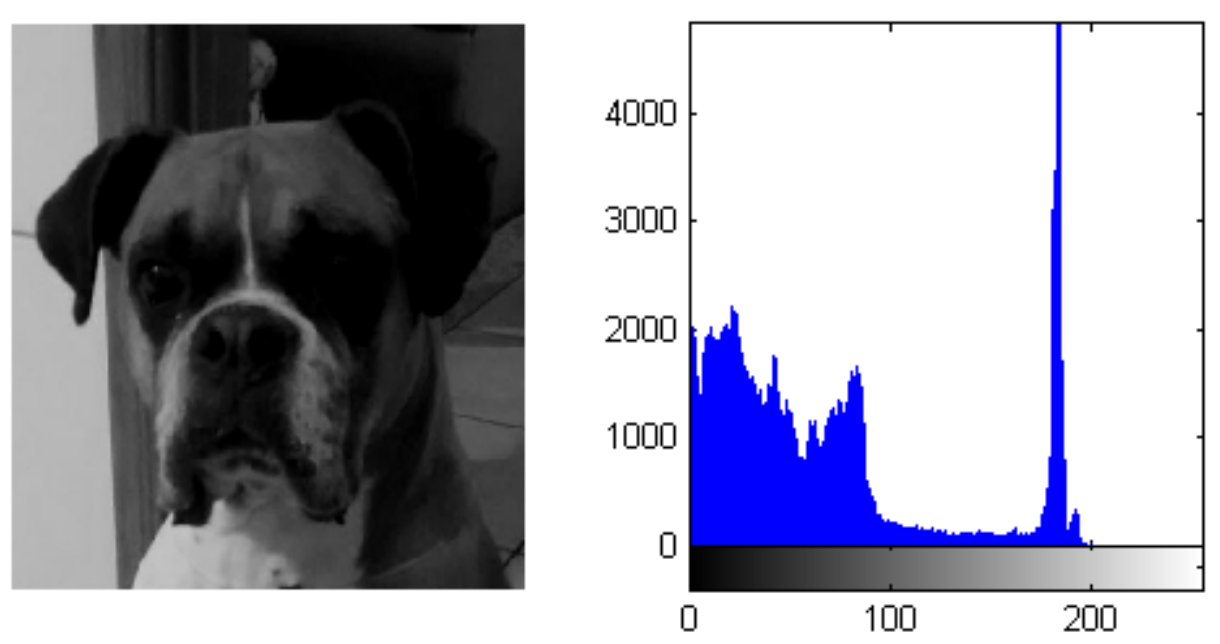

Figura 4.8-Imagem em tons de cinza (esq) e seu respectivo histograma (dir).

Fonte(s): Elaborada pelo autor.

As transformações mais simples são as que alteram o brilho e o contraste de imagem. $O$ brilho, é definido por:

$$
g(x, y)=f(x, y)+b
$$
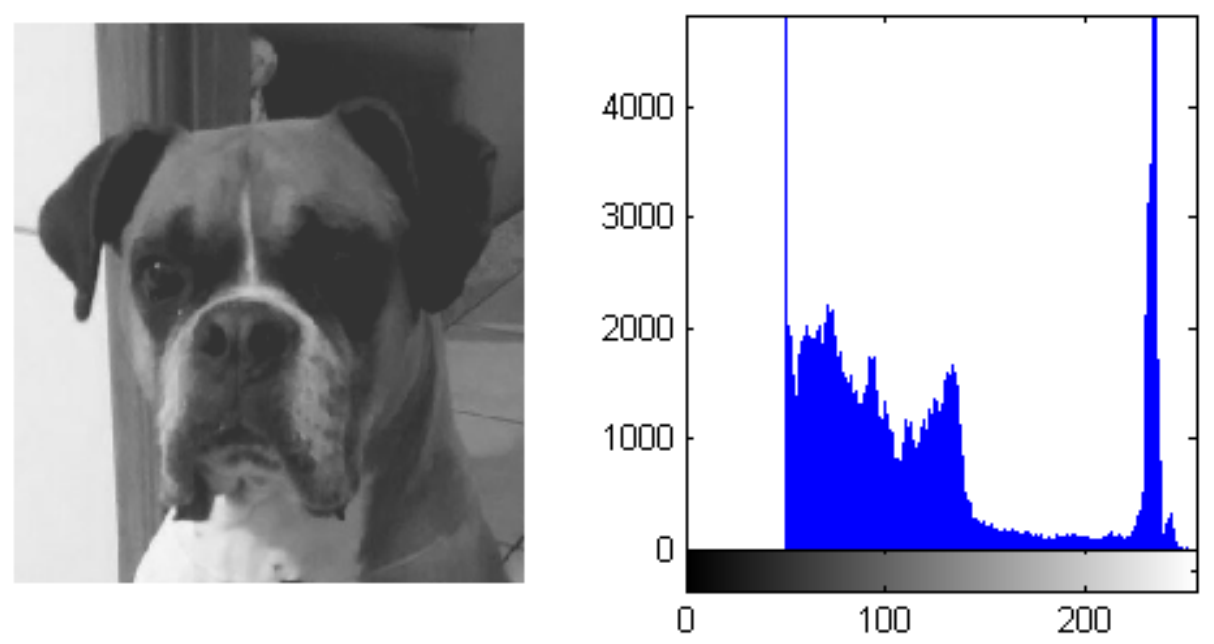

Figura 4.9 - Exemplo de imagem com o brilho alterado(dir) e seu respectivo histograma(esq).

Fonte(s): Elaborada pelo autor.

o que traz como consequência, uma translação do histograma da imagem. Se essa 
translação for um deslocamento para a esquerda do gráfico, com $(b<0)$ temos o escurecimento da imagem; caso contrário $(b>0)$, teremos o aumento do brilho.

O contraste, por sua vez, manipula a diferença de intensidades entre os pixels e é dado pela equação:

$$
g(x, y)=c . f(x, y)
$$

Assim, para que uma imagem tenha um aumento de contraste deve-se ter $c>1$. A redução do contraste ocorre para $c$ cujo valor deve ficar entre $0<c<1$.
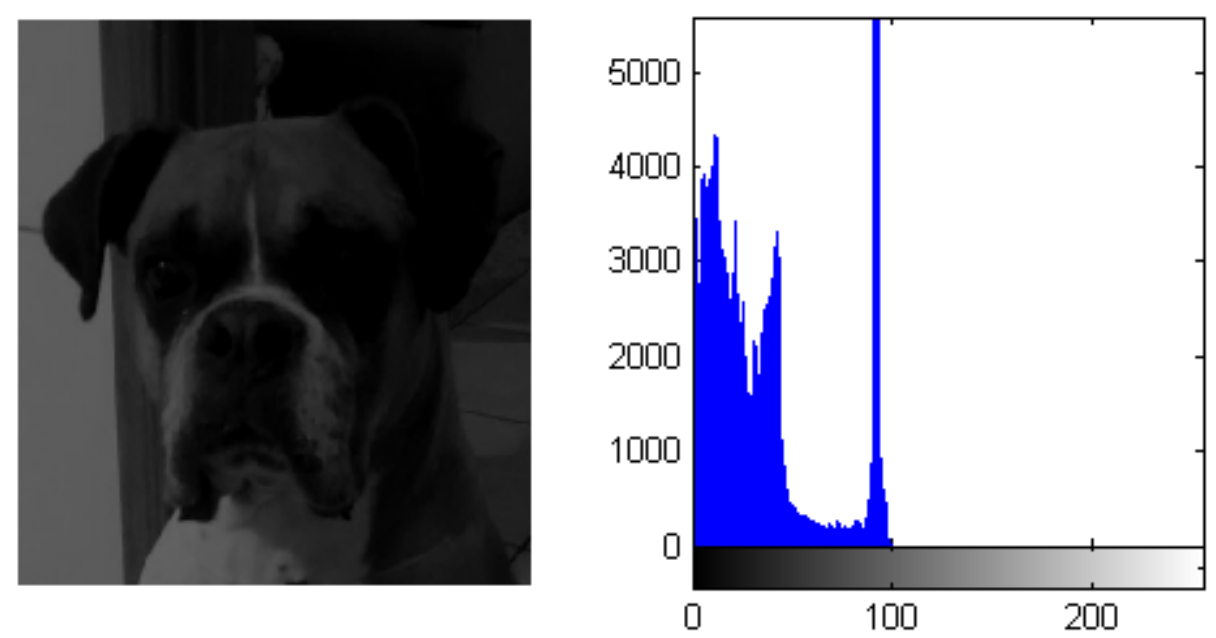

Figura 4.10 - Exemplo de imagem com alteração de contraste (dir) e seu respectivo histograma (esq).

Fonte(s): Elaborada pelo autor.

A equalização de histograma é outra transformação normalmente aplicada. Tem como objetivo equalizar as intensidades dos pixels da imagem, de forma que seu histograma se apresente igualmente distribuído entre os intervalo mínimo e máximo do histograma, de forma regularmente espaçada.

$$
g(x, y)=\frac{m-1}{\sum_{j=0}^{m} n_{j}} \sum_{j=0}^{f(x, y)} n_{j}
$$

sendo $m$ o número total de tons de cinza da imagem $f ; m_{j}$ o número de pixels que tem em particular tons de cinza $j$.

Outra operação simples que se pode fazer é a normalização do histograma. A normalização ou autoescala faz um ajuste dos pixels dentro dos limites de máximo e mínimo de intensidade 
por meio de um simples operação de normalização dos pixels, dada por:

$$
g(x, y)=I_{\max } \frac{f(x, y)-\min \{F\}}{\max \{F\}-\min \{F\}}
$$

Sendo $I_{\max }$ o valor de intensidade máxima que um pixel pode assumir (normalmente 255).

\subsubsection{Filtros em imagens}

Um filtro de suavização tem por principal objetivo a minimização de ruídos em um sinal. Nesta seção serão tratados filtros de suavização aplicados no domínio do espaço e frequência com uso de convolução.

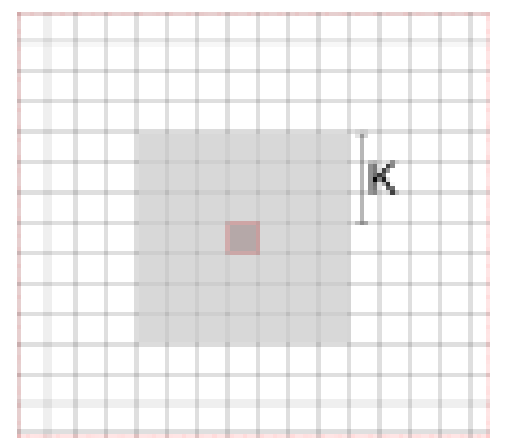

Figura 4.11-Diagrama mostrando os $\mathrm{K}$ vizinhos de um píxel.

Fonte(s): Elaborada pelo autor.

Um exemplo de filtro de suavização é o da mediana, onde $g(x, y)$ assume o valor da mediana dos valores de pixels vizinhos à $f(x, y)$, isto é, dado um pixel $f(x, y)$ este filtro retorna à mediana do conjunto dos pixels vizinhos, contidos no bloco $(2 K+1)^{2}$, incluindo o próprio $f(x, y)$.

A relação de vizinhança é definida por $K$, que é a distância em pixels, do pixel de referência $f(x, y)$ (ou central), e informa a distância do pixel de interesse à borda da região de vizinhança. O filtro da mediana tem um excelente desempenho nos casos de ruído de tipo "sal-pimenta".

$$
g(x, y)=\text { mediana }\{f(x+i, y+j) \mid-K \leq i \leq K e-K \leq j \leq K\}
$$

Outro filtro de suavização bastante comum é o da média. Esse filtro retorna o novo valor de $g(x, y)$ com base no valor médio da intensidade entre $f(x, y)$ e seus $(2 K+1)^{2}-1$ vizinhos.

$$
g(x, y)=\frac{1}{(2 K+1)^{2}} \sum_{k=-K}^{k=K} \sum_{l=-K}^{l=K} f(x+k, y+l)
$$


Outra maneira para a visualização da aplicação desse filtro é imaginarmos uma máscara cujos elementos são valorados por $\frac{1}{(2 K+1)^{2}}$. Essa matriz ou máscara percorre a imagem original de dimensões $M x N$, deslocando-se elemento a elemento.

A medida que a máscara percorre a imagem, ocorre uma operação de multiplicação elemento à elemento e a soma desses. O resultado é atribuído à $g(x, y)$ que resultará em um pixel na nova imagem $\mathrm{G}$.

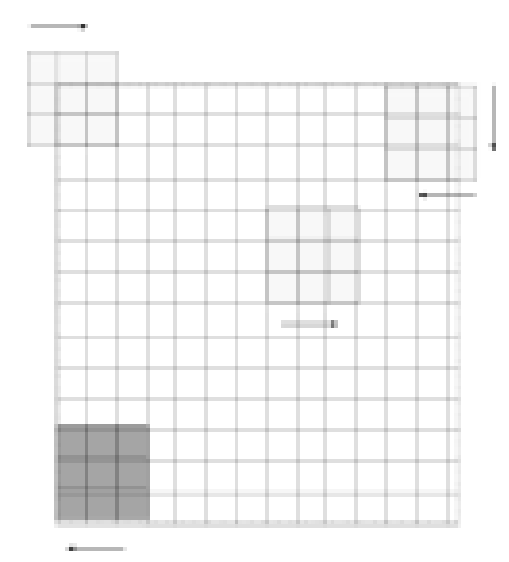

Figura 4.12-Processo de convolução de um filtro sobre uma imagem.

Fonte(s): Elaborada pelo autor.

Esse processo de: deslocamento do filtro sobre a imagem, multiplicação elemento a elemento e soma (cujo resultado definirá o valor do pixel da nova imagem criada), é denominado de convolução discreta. Deve-se observar que $F$ permanece inalterado e que uma nova imagem $G$ é criada.

O processo de aplicação do filtro médio pode ser generalizado, representando-se o filtro médio por uma matriz $h(i, j)$ (denominado de kernel). Este kernel usa o mesmo sistema de coordenadas para a descrição de vizinhança, e estão no intervalo $-K, K$ para as linhas e colunas da matriz. Essa generalização permite que diversos tipos de filtros $h(i, j)$ sejam criados e aplicados por :

$$
g(x, y)=\sum_{i=-K}^{K} \sum_{j=-L}^{L} h(i, j) f(x+i, y+j)
$$

Note que a expressão anterior representa a aplicação do filtro $h(i, j)$ em um pixel $f(x, y) d a$ imagem F. A aplicação do filtro em toda imagem é realizada pela convolução entre kernel e imagem, sendo representado por:

$$
g(x, y)=h(i, j) \star f(x, y)
$$


O filtro da média, embora simples, apresenta como problema o surgimento de gradientes e bordas que interferem na imagem gerada $(1,24)$.

Outro filtro utilizado para a suavização de uma imagem, é o Gaussiano. No domínio do espaço, o kernel $h(i, j)$ do filtro gaussiano é dado por:

$$
h_{\sigma}(i, j)=\frac{1}{2 \pi \sigma^{2}} e^{\left(\frac{-\left((i-K)^{2}+(j-L)^{2}\right.}{2 \sigma^{2}}\right)}
$$

Mesmo fazendo-se uso de um kernel gaussiano, a convolução discreta possui a inconveniência de gerar o chamado efeito de borda - pois a máscara, ao tentar processar os pixels da região de borda da imagem, não encontra pixels correspondentes aos de sua máscara.

Tentando contornar esse problema, algumas estratégias podem ser adotadas mas, para cada uma há um inconveniente $(1,15,24)$ :

- ignorar as regiões de borda - apresenta como desvantagem uma imagem resultante de tamanho menor. Caso haja a necessidade de aplicações sucessivas ou o uso de máscaras de tamanhos consideráveis, a imagem final pode apresentar grandes perdas de sua área.

- preenchimento da região, em que o kernel não encontro um pixel da imagem correspondente, com valores próximos dos valores de borda - esse método resolve o problema de redução da imagem mas acaba gerando gradientes que interferem na informação da imagem final.

- complementar a imagem com a região da borda oposta, como se a imagem fosse uma função periódica. Essa estratégia também pode gerar efeitos de bordas, dependendo dos valores da borda oposta.

Uma alternativa interessante para a resolução desses efeitos é aplicar uma mudança de base, na imagem, passando esta do domínio do espaço, para o domínio da frequência, por meio da transformada de Fourier. A transformada de Fourier $(1,17,24)$ propõe representar qualquer sinal $f(x, y)$ como o resultado da soma de sinais senoidais.

$$
F(u, v)=\Im\{f(x, y)\}=\iint_{-\infty}^{\infty} f(x, y) \cdot e^{-i 2 \pi(u x+v y)} d x d y
$$

sendo $e^{-i 2 \pi(u x+v y)}=\cos (2 \pi(u x+v y))+i \sin (2 \pi(u x+v y))$.

A função $f(x, y)$ é então transformada em $\mathrm{F}(\mathrm{u}, \mathrm{v})$ sendo que os elementos do par $(u, v)$ representam a quantidade da referida função senoidal para compor a função original. A transformação da função do domínio da frequência, para novamente no domínio do espaço, pode 
ser obtida pela função inversa de Fourier, dada por $(1,17,24)$ :

$$
f(x, y)=\Im^{-1}\{F(u, v)\}=\iint_{-\infty}^{\infty} F(u, v) \cdot e^{i 2 \pi(u x+v y)} d u d v
$$

Uma característica importante dessa transformada é o teorema de convolução. Esse define que o produto da transformada de Fourier de duas funções $\mathrm{H}(\mathrm{u})$ e $\mathrm{F}(\mathrm{u})$ é igual ao resultado da convolução dessas, no domínio do espaço:

$$
f(t) \star h(t) \Leftrightarrow H(u) . F(u) \quad \text { o que implica em: } \quad f(t) . h(t) \Leftrightarrow H(u) \star F(u)
$$

Assim, trabalhar com imagens no domínio da frequência traz como vantagem a possibilidade de realizar operações de convolução de maneira rápida, transformando $f(x, y)$ e $h(i, j)$ em $\mathrm{F}(\mathrm{u}, \mathrm{v})$ e $\mathrm{H}(\mathrm{u}, \mathrm{v})$, pela transformada de Fourier, e aplicando-se a inversa da transformada sobre o resultado da multiplicação entre $F(u, v)$ e $H(u, v)$, conforme pode ser visto nas equações (4.5.13) e (4.5.14).

$$
\begin{gathered}
F(u)=\Im\{f(t)\} ; \quad H(u)=\Im\{h(t)\} \\
\Im\{H(u) \cdot F(u)\}^{-1}=f(t) \star h(t)
\end{gathered}
$$

Outra vantagem de se trabalhar no domínio da frequência é a possibilidade de filtragem de frequências específicas para a restauração de uma imagem, sendo o filtro gaussiano o mais indicado para kernel da convolução.

$$
h(x, y)=\frac{1}{2 \pi \sigma^{2}} e^{\left.\left(\frac{-\left((x)^{2}+(y)^{2}\right.}{2 \sigma^{2}}\right)\right)}
$$

\subsubsection{Multiresolução - wavelets}

Wavelets é o resultado de uma esforço muticiplinar conjuntoque foi reunido e organizado, no final dos anos 1980, por Estephane Mallat $(20-22)$

As transformações ou algoritmos wavelets processam os dados em diferentes resoluções $(2,16$ 18), permitindo observar " 'tanto as árvores quanto a floresta"' além disso, ao contrário da transformada de Fourier, as transformadas de wavelet permitem uma análise de resolução tanto no espaço quanto na frequência (21). Assim como a transformada de Fourier, há wavelets aplicáveis tanto no domínio contínuo (CWT-Continuos Wavelet Transform), quanto no discreto (DWT-Discret Wavelet Tranform) $(20-22)$.

Em uma transformação CWT (Continuos Wavelet Tranform), para que uma função $(\varphi(t))$ seja considerada uma função wavelet, esta deve atender as seguintes condições(20): 
i) que sua integral seja igual a zero e;

$$
\int_{-\infty}^{\infty} \psi(t) d t=0
$$

ii)que sua energia seja finita(20).

$$
\int_{-\infty}^{\infty}|\psi(t)|^{2} d t<\infty
$$

Quando uma função cumpre essas duas condições, diz-se que esta é uma função quadrado integrável, ou que pertence ao conjunto $\mathfrak{L}^{2}(\Re)$. Assim, a transformada wavelet é calculada como o produto interno de $x(t)$ escalado e transladado em versões de uma função $\varphi(t)$ chamada de wavelet $(20)$.

$$
W_{x}(b, a)=|a|^{-\frac{1}{2}} \int_{-\infty}^{\infty} x(t) \psi^{*}\left(\frac{t-b}{a}\right) d t
$$

Se considerarmos que $t$ é um impulso de resposta passa-banda, então a análise wavelet pode ser entendida como uma análise passa-banda(22). Dessa forma, uma contração da função, correspondendo a uma versão de passa-alta da função protótipo, faz uma análise de frequência - a dilatação da função, correspondendo a uma versão passa-baixa do mesmo protótipo (Figura 4.13).
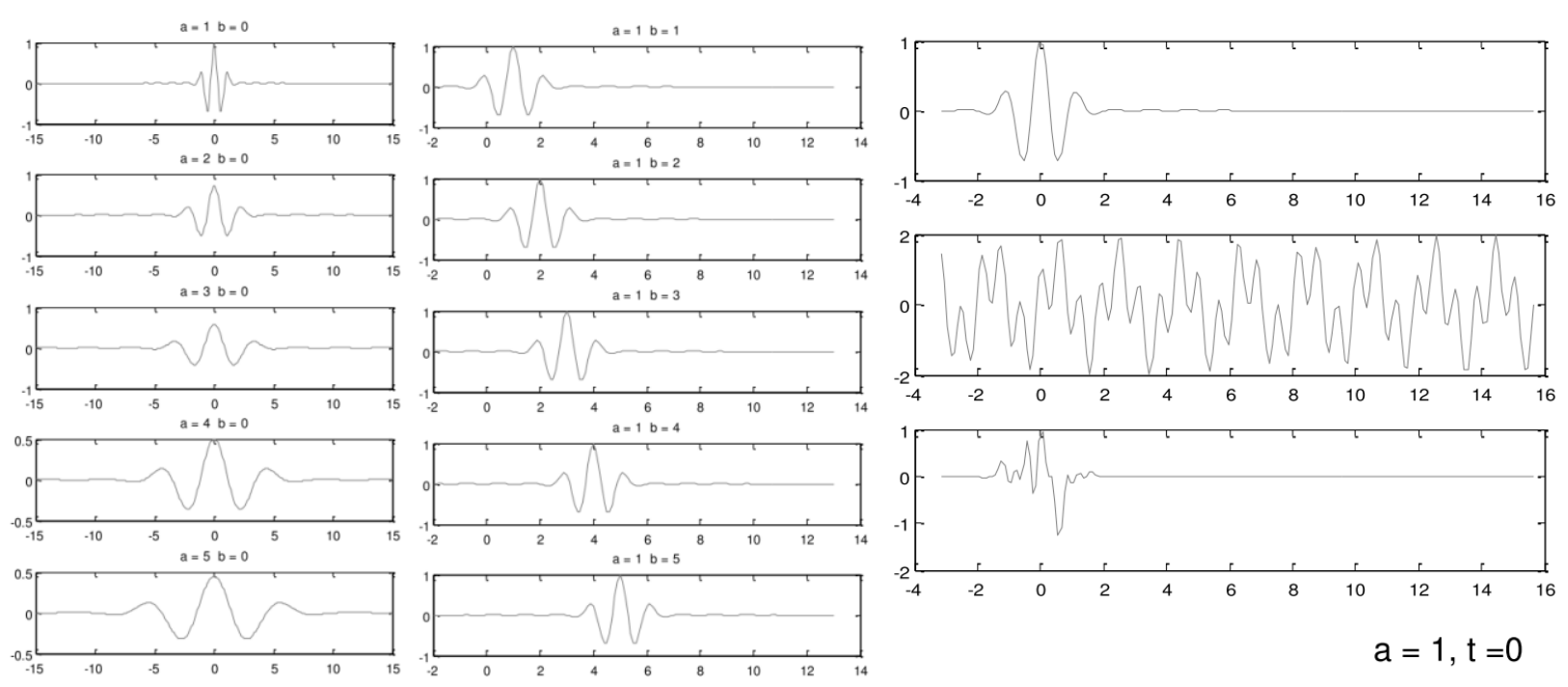

Figura 4.13 - Variação do parâmetro que determina a frequência(esquerda); variando-se o parâmetro $t$ há variação de translação da função(centro) ; transformada wavelet aplicada em um sinal e seu respectivo resultado(direita).

Fonte(s): Elaborada pelo autor. 
Uma característica importante de uma função wavelet é sua ortogonalidade. A ortogonalidade, quando presente, garante que a função wavelet seja inversível; o que é um atributo bastante interessante para a análise ou síntese de imagens. As funções Marlet, chapéu mexicano e Meyer, por não serem ortogonais, não possuem função inversa, embora haja uma transformada discreta para Meyer adaptada.Com relação a funções wavelets ortogonais há algumas famílias, tais como: bi-orthogonais, Daubechies, cooiflets e symlets, que são usadas tanto em CWT, quanto em $\operatorname{DWT}(1,20)$.

As transformadas DWT invertíveis são operações lineares cuja função wavelet inversa é a transposta da matriz da própria função transformação.Para as DWTs, há um conjunto de funções básicas chamadas de wavelets mãe $(20,21)$.

$$
\begin{gathered}
f(t)=\sum_{k=-\infty}^{\infty} c_{k} \phi(t-k)+\sum_{k=-\infty}^{\infty} \sum_{j=-\infty}^{\infty} d_{j, k} \psi\left(2^{j} t-k\right), \\
\phi(t)=\left\{\begin{array}{cl}
1, & 0 \leq t<1 \\
0, & \text { para outros valores de } t,
\end{array} \quad(t)=\left\{\begin{array}{cc}
1, & 0 \leq t<0.5 \\
-1, & 0.5 \leq t<1 . \\
0, & \text { para outros valores de } t,
\end{array}\right.\right.
\end{gathered}
$$

Assim a função $f(t)$ é obtida por meio das somas de funções wavelets: $\phi(t)$ como função pai e $\varphi(t)$ função mãe. Nessa transformação, o objetivo é identificar os parâmetros $c_{k}$ e $d_{j, k}$, sendo que os parâmetros $j$ e $k$ tratam respectivamente da escala e translação, aplicada à transformada. Um exemplo é a transformada de Haar (1), que decompõe um sinal em duas partes (ou subsinais): a primeira chamada de tendência, aproximação ou média é dado por $c_{k}$ e; a segunda chamada de diferença ou flutuação é dado por $d_{j, k}$. Na transformada, cada subsinal apresenta a metade dos elementos do sinal original(Figura 4.14).
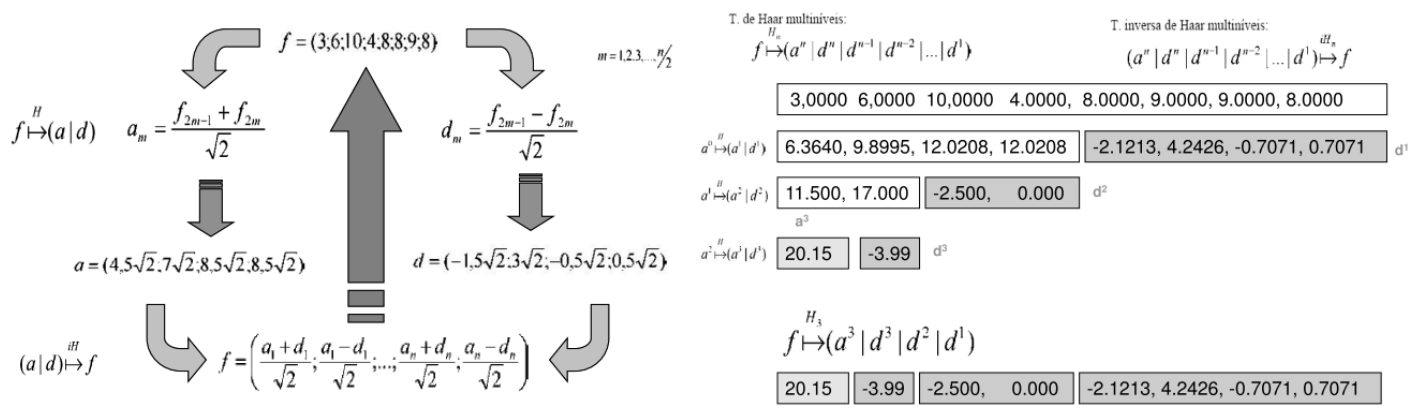

Figura 4.14 - Diagrama mostrando o processo de aplicação da transformada de Harr(esq) e; exemplo de um resultado da aplicação da transformada de Haar, em um sinal 1D(dir).

Fonte(s): Elaborada pelo autor. 
A transformada wavelet de Haar apresenta duas características bastante interessantes. A primeira é que a energia contida na função $f(t)$ se conserva em toda a transformada. A outra, é a compactação do sinal. A segunda tem uma particular importância para o processamento de imagens, pois permite que ruídos sejam removidos.

$$
\varepsilon(f)=\sum_{i=1}^{n} f(i)^{2} \quad \text { isto é } \quad \varepsilon(f)=\varepsilon\left(a^{1} \mid d^{1}\right)=\varepsilon\left(a^{2}\left|d^{2}\right| d^{1}\right)=\varepsilon\left(a^{n}\left|d^{n}\right| \ldots . \mid d^{1}\right)
$$

Assim, similarmente à transformada discreta de Fourier 2D, a aplicação da transformada wavelet 2D é feita por etapas. Na primeira a transformada é aplicada nas linhas e na segunda segunda, nas colunas.

Observando a Figura 4.15 fica claro que uma imagem é processada, em uma primeira etapa, no sentido das linhas, tendo como filtros $L o_{D}$ e $H i_{D}$. Essas abreviações já explicitam o tipo do filtro usado: $L o_{D}$ se refere à aplicação de um filtro passa-baixa, enquanto $H i_{D}$ se refere a um filtro passa-alta. Os resultados obtidos da varredura em linha são submetidos à transformada no sentido das colunas. O resultado obtido, representado por $c A$, é a aproximação da imagem e, $c D_{\text {Horizontal }}, c D_{\text {Vertical }}$ e $c D_{\text {Diagonal }}$, correspondem aos sinais de alta frequência, ou "ruídos" da imagem, presentes nos respectivos sentidos horizontal, vertical e diagonal.

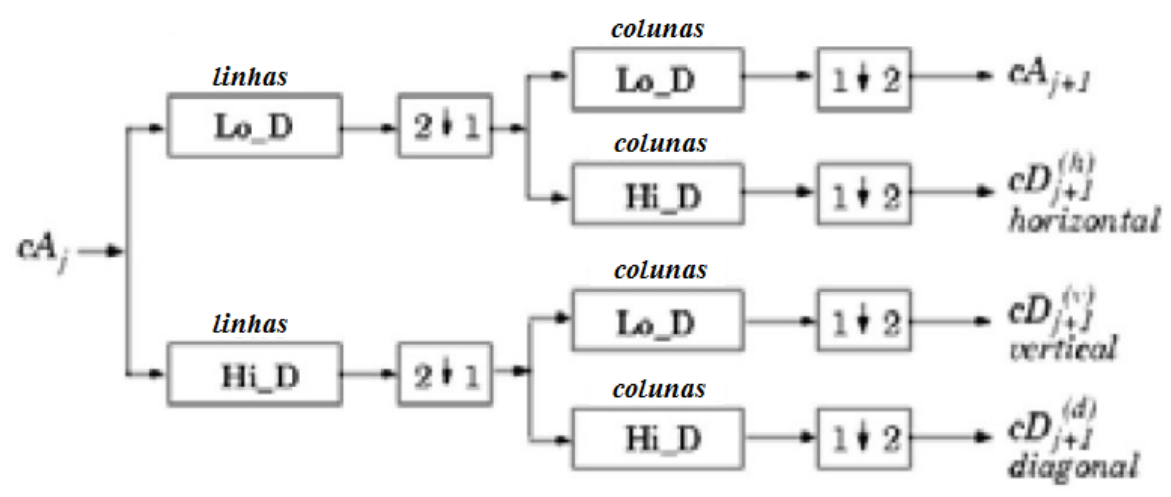

Figura 4.15-Diagrama ilustrando a aplicação de uma transformada discreta wavelet.

Fonte(s): WEEKS (3). 


\subsection{Considerações finais}

Neste capítulo, entre as Seção 4.1 e 4.4, foram abordados os conceitos e definições de imagens multiespectrais e hiper-espectrais. Também foram citados os problemas considerados especiais no que se refere ao seu processamento, tais como: substituição de base, decomposição espectral e sua representação em um sistema de cores para o mapeamento e visualização das informação contida na imagem. Também foram abordados os conceitos e a relação entre visão, cores e espectro. Foram descritos os sistemas de cores CIE RGB, CIE XYZ e o CIExy e seu referido diagrama de cores. Na Seção 4.5, foram abordados os conceitos de processamento de imagens baseados em histograma, filtros de suavização (no domínio do espaço e frequência - com a transformada de Fourier) e o uso da transformada de Fourier no domínio da frequência. Por fim, a seção é finalizada com os conceitos de multi-resolução com uso de wavelts. Os conceitos de processamento de imagens abordados neste capítulo foram utilizados no desenvolvimento do método. 


\section{CAPÍTULO 5}

\section{Descrição do método desenvolvido}

O método computacional de mapeamento espaço-espectral, desenvolvido neste trabaIho, está dividido em quatro fases : aquisição, processamento numérico, segmentação por agrupamento espectral e, mapeamento e visualização. O diagrama da Figura 5.1 ilustra o encadeamento dessas etapas, as quais são descritas nas seções seguintes.

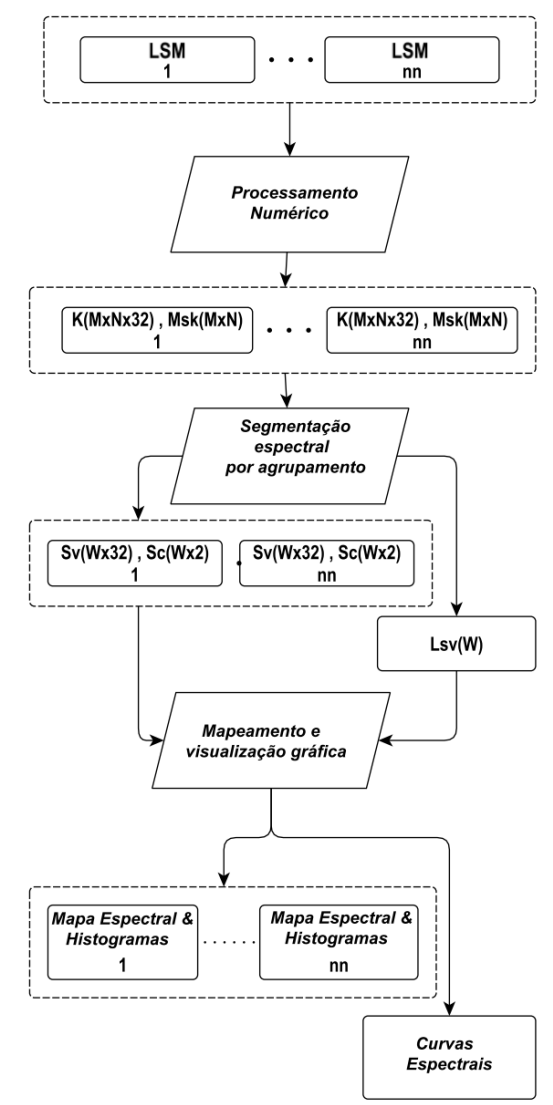

Figura 5.1 - Processo de mapeamento espectro-espacial de imagens de LSM. Diagrama com as principais etapas do processo e seus produtos.

Fonte(s): Elaborada pelo autor. 


\subsection{Aquisição das imagens multiespectrais}

A fase de aquisição compreende a captura de imagens multiespectrais realizadas em um microscópio confocal de varredura a laser por fluorescência, o qual retorna arquivos no formato LSM (formato de arquivo que armazena imagens multiespectrais, utilizado pela Zeiss). A imagem multiespectral armazenada no formato LSM é composta por 32 canais, com profundidade de pixel de 16bits por canal, totalizando 512bits para cada pixel multiespectral.

O método desenvolvido e apresentado nas seções seguintes não é dependente do formato do arquivo de onde se originam os dados de imagens multiespectrais. Um módulo de leitura exporta os dados multiespectrais do formato LSM para uma matriz $I_{(M x N x 32)}$ - formato do sistema desenvolvido. Para outros formatos de arquivos multiespectrais, podem ser desenvolvidos módulos de exportação.

\subsection{Processamento Numérico}

Após a exportação dos arquivos LSM para a matrizes de dados numéricos $I_{(M x N x 32)}$, essas passam por um processamento numérico, para o tratamento de algumas características que podem interferir no método(Figura 5.2). Primeiramente é importante reforçar que cada pixel consiste de um vetor espectral caracterizado por 32 canais, sendo que cada canal pode representar até 65.536 intensidades, pois tem uma profundidade de pixel de $\left(2^{16 b i t s}\right)$ - o que gera um diversidade de $2^{512}$ curvas espectrais, por pixel multiespectral, considerando os 32 canais.

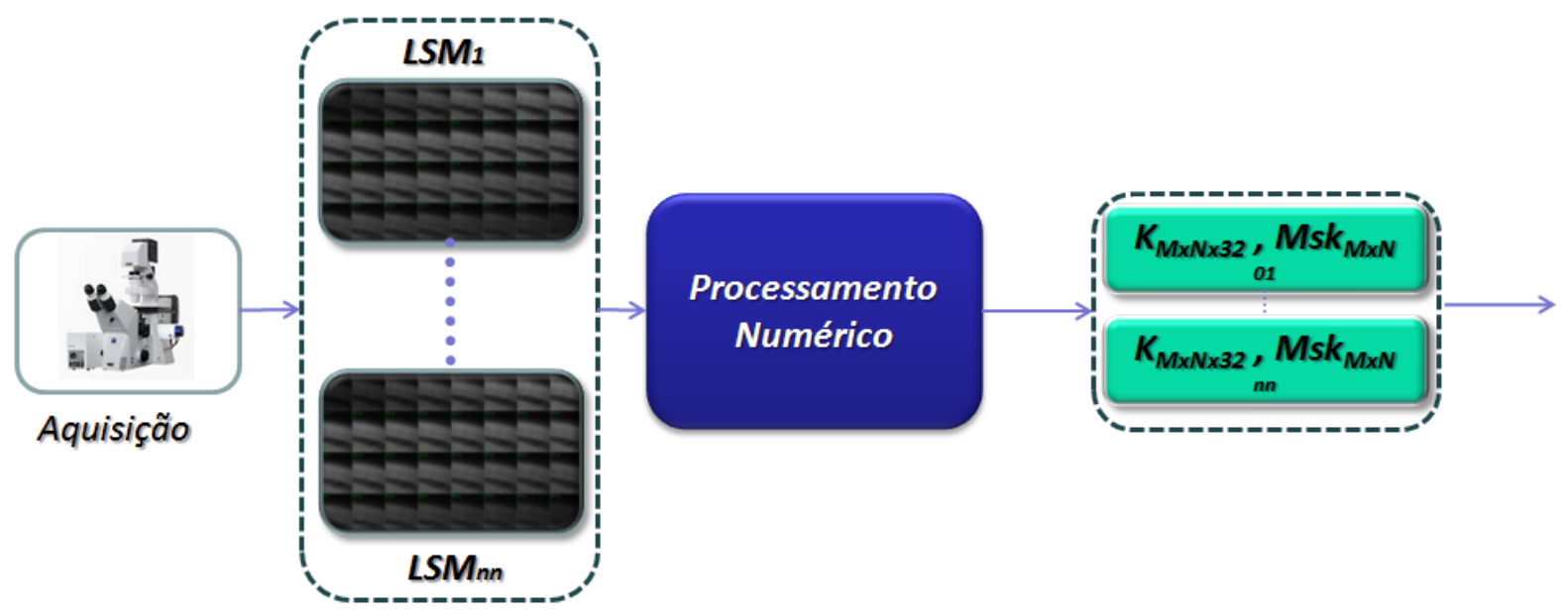

Figura 5.2-Aquisição seguida pelo processamento numérico. 
Conforme discutido em capítulo anterior, curvas espectrais são utilizadas como assinaturas para a identificação de compostos. Assim, dois compostos de mesmo tipo devem apresentar a mesma assinatura espectral. Na aquisição de imagens multiespectrais, há pequenas variações na intensidade das assinaturas (com relação à amplitude do espectro), devido a diferentes distâncias da superfície de observação, dentro do volume focal. Essas assinaturas espectrais, com pequenas variações, seriam imperceptíveis aos olhos humanos mas, se utilizadas em um algoritmo de classificação, podem ser interpretadas como compostos distintos.

Por isso, a fase de processamento numérico(Figura 5.2) é responsável por remover distorções de informação e garantir que as curvas espectrais com mesma informação química tenham a mesma forma. Além disso, outro objetivo a ser cumprido por essa etapa é separar a região da amostra do plano de fundo, que não possui informação relevante para análise.

Os produtos esperados nesta etapa do método são as matrizes $K_{(M x N x 32)}$ e $M s k_{(M x N)}$. A primeira é o resultado de uma série de operações aplicadas na matriz de aquisição $I_{(M x N x 32)}$, para a remoção das distorções durante o processo de aquisição, e a segunda matriz é uma máscara binária, que contém o recorte da região de interesse( diagrama detalhado na Figura 5.3), que elimina a região de fundo nos processamentos seguintes.

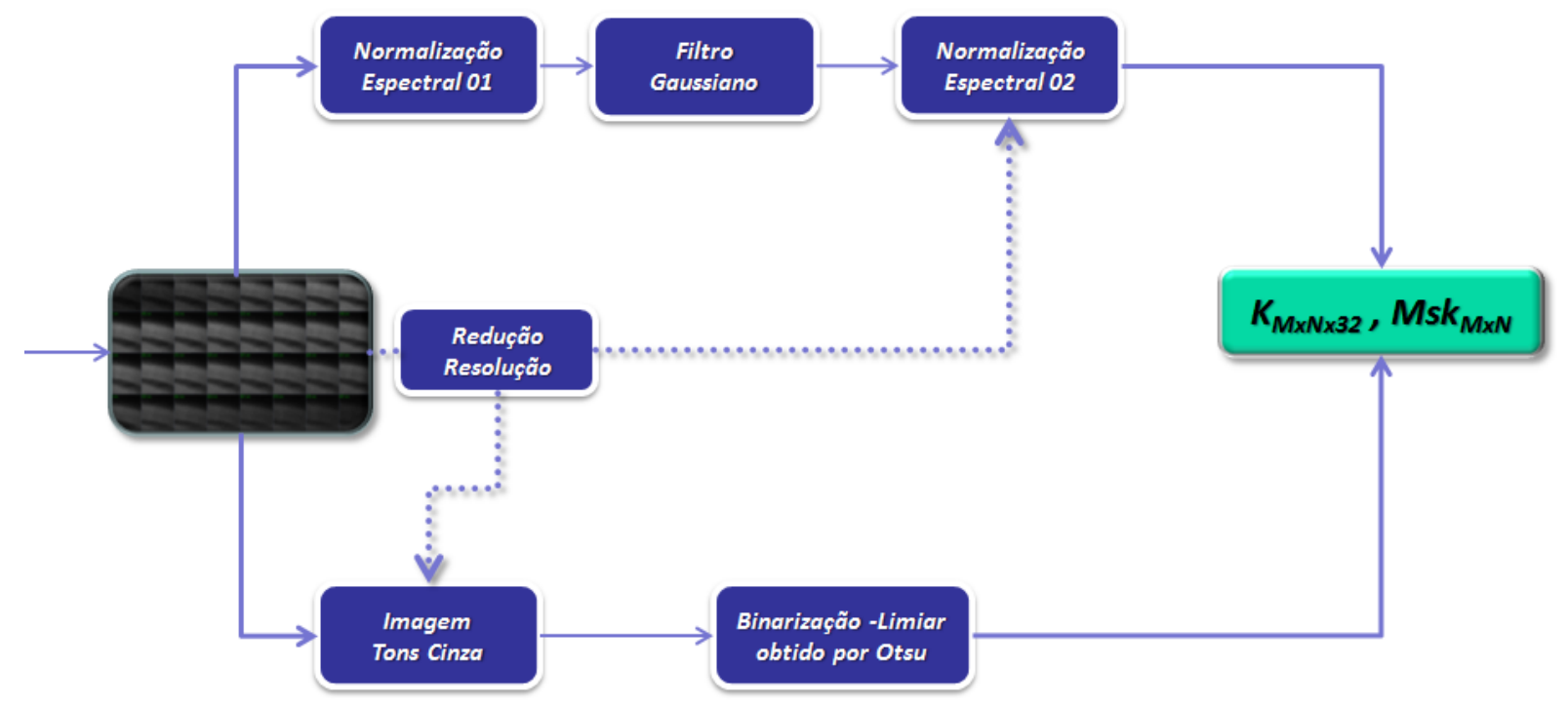

Figura 5.3-Detalhamento do processo de processamento numérico.

Fonte(s): Elaborada pelo autor.

Para a geração da matriz $K_{(M x N x 32)}$, inicialmente, há uma normalização espectral individual aplicada na matriz $I_{(M x N x 32)}$, que uniformiza a amplitude de todas as curvas espectrais, de modo que o pico máximo de cada espectro tenha valor em 1 .

A Figura 5.4 ilustra a normalização aplicada em cada vetor espectral. O resultado da 
normalização é a matriz $I_{(M x N x 32)}^{n}$ dado por;

$$
I_{(M x N x 32)}^{n}=\frac{I_{(M, N, 1 \ldots 32)}}{\max \left\{I_{(M, N, 1 \ldots 32)}\right\}}
$$

Após a primeira normalização espectral é aplicado um filtro gaussiano. Isso se faz necessário devido à normalização anterior que também amplifica o ruído de fundo da amostra.

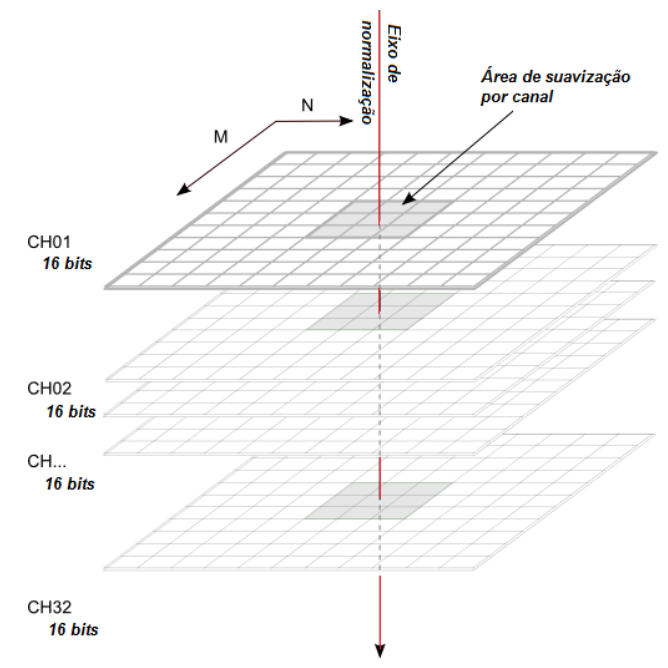

Figura 5.4-Normalização espectral aplicada na matriz de imagem multiespectral.

Fonte(s): Elaborada pelo autor.

A aplicação do filtro é realizada em cada canal, no mesmo plano deste, conforme ilustra a Figura 5.4. Por ser mais rápido, o filtro gaussiano é aplicado por convolução no domínio da frequência. Quando a memória disponível no computador para locação é limitante na operação de suavização no domínio da frequência, o filtro é aplicado no domínio do espaço. O resultado é dado pela matriz, $I_{(M x N x 32)}^{n g}$.

$$
I_{(M x N x 32)}^{n g}=I_{(M x N x 32)}^{n} * g(x, y, \sigma)
$$

Um efeito colateral após a aplicação do filtro gaussiano é o efeito de encolhimento da assinatura espectral. Por isso, uma nova normalização é feita, resultando na matriz $K_{(M x N x 32)}$.

$$
K_{(M x N x 32)}=\eta\left(I_{(M x N x 32)}^{n g}\right)
$$

A matriz $K_{(M x N x 32)}$ tem agora todos os vetores espectrais, de mesma informação química, com a mesma forma. Um caminho alternativo para a geração da matriz $K_{(M x N x 32)}$ é mostrado no diagrama da Figura 5.3. O módulo Redução Resolução é uma opção de aplicação da transformada wavelet para a redução de resolução, principalmente no caso das imagens 
multiespectrais cujo tamanho seja impedimento para o processamento, devido ao limite na alocação de memória. A redução de resolução é aplicada individualmente no plano de cada canal. Dessa forma, a profundidade de bits de cada pixel se mantém constante, alterando-se somente as dimensões $(M x N)$, isto é $W\left\{I_{(M x N x 32)}\right\}=I_{(M / 2 x N / 2 x 32)}$. Deve-se notar que, terminada a redução de resolução, é aplicada diretamente o que seria a segunda normalização. Isso se deve ao fato da transformada wavelet, conforme explicado no capítulo anterior, já reduzir os ruídos de fundo. A matriz multiespectral resultante da alteração de resolução(quando aplicada), também é utilizada na construção da máscara binária.

Outra operação realizada na fase de processamento numérico é a construção de uma máscara binária $M s k_{(M x N)}$. Essa máscara é utilizada, na etapa de segmentação, para separar os espectros da região de interesse(amostra), dos espectros da região de fundo. Para se obter a máscara é necessário converter os valores dos pixels da imagem, que podem variar entre 0 e $2^{\text {bits }}-1$ (bits de profundidade do pixel), em zeros ou uns, utilizando para isso, um valor limiar. Um valor de limiar correto permite a separação da imagem do objeto de seu plano de fundo. Neste trabalho, o valor limite é definido por Otsu - um algoritmo muito bem estabelecido e referenciado[1]. Para aplicar o algoritmo de Otsu em uma imagem multiespectral, é necessário que esta seja convertida em uma imagem em tons de cinza. A imagem em tons de cinza é obtida pela média simples da matriz multispectral $I_{(M x N x 32)}$, em relação aos seus canais, resultando na matriz $\overline{I_{(M x N)}}$.

$$
\overline{I_{(M x N)}}=\frac{1}{32} \sum_{l=1}^{l=32} I_{(M x N x l)}
$$

A matriz máscara $M s k_{(M x N)}$ é o resultado do limiar dado por $t_{o t s u}=\operatorname{Otsu}\left(\overline{I_{(M x N)}}\right)$ aplicada em $\overline{I_{(M x N)}}$ por:

$$
M s k_{M, N}=\left\{\begin{array}{l}
M s k(m, n)=0, \quad \text { se } \overline{I_{(m, n)}} \leq t_{\text {Otsu }}, \\
M s k(m, n)=1, \quad \text { se } \overline{I_{(m, n)}}>t_{O t s u}, \\
\text { para } 1 \leq m \leq M \quad \text { e } 1 \leq n \leq N .
\end{array}\right.
$$

A máscara $M s k_{(M x N)}$ e a matriz $K_{(M x N x 32)}$ são utilizadas na fase de segmentação por agrupamento espectral. 


\subsection{Segmentação por agrupamento espectral}

Com base nas matrizes $M s k_{(M x N)}$ e $K_{(M x N x 32)}$, a execução desta etapa do método produzirá o conjunto de espectros de interesse, dado por $S v_{(W x 32)}$ e seus respectivos; conjunto de coordenadas dos espectros de interesse, $S c_{(W x 2)}$; conjunto de rótulos de cada um dos espectros de interesse, dado por $L S v_{(W)}$ e; o conjunto de Centroides que representam os espectros médios, de cada agrupamento de vetores de interesse (Figura 5.5).

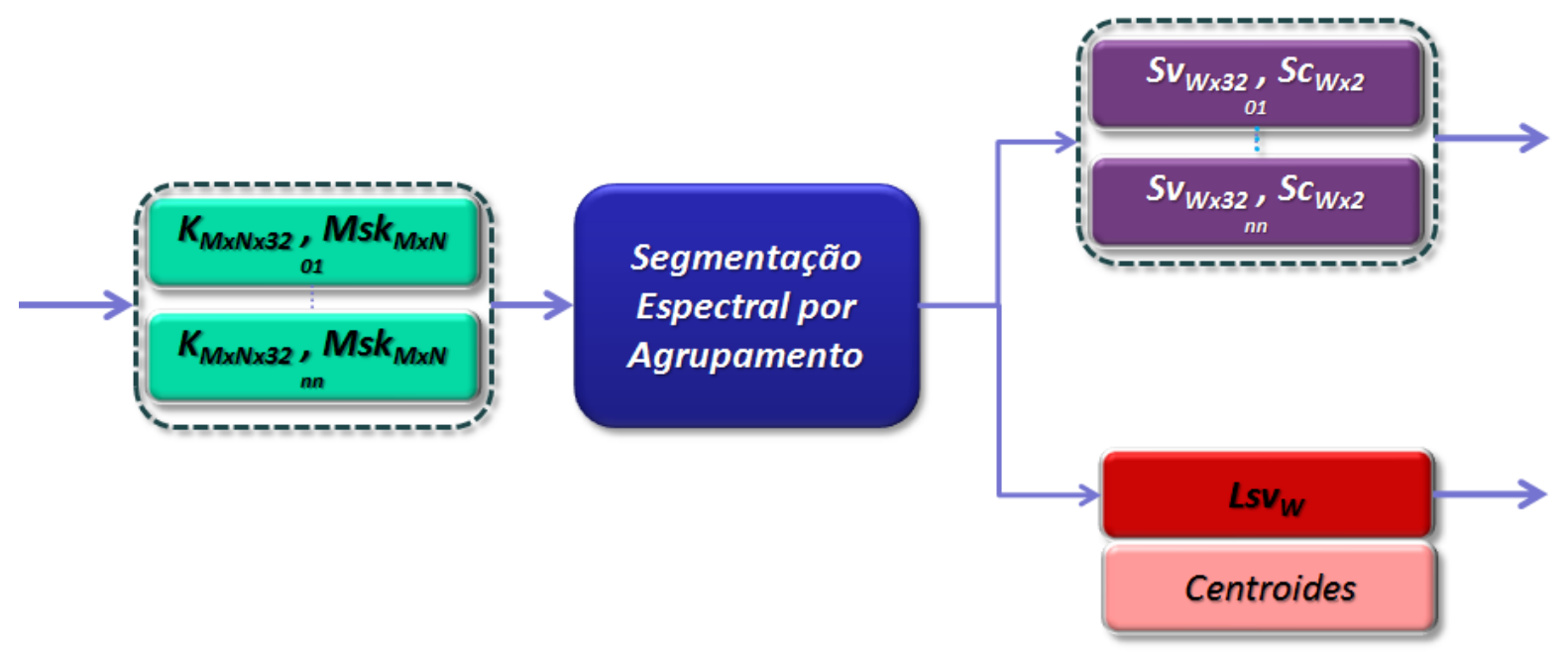

Figura 5.5-Diagrama da etapa de segmentação espectral.

Fonte(s): Elaborada pelo autor.

Como pode ser visto no detalhamento do módulo de segmentação por agrupamento espectral (Figura 5.6), a partir da matriz $M s k_{(M x N)}$, é possível selecionar um subconjunto $S v_{(W x 32)}$ de vetores espectrais de interesse de $K_{(M x N x 32)}$ e suas respectivas coordenadas, as quais são armazenadas em $S c_{(W x 2)}$, dado por:

$$
S v_{(w, 1 . .32)}=\left\{K_{(m, n, 1 \ldots 32)} \mid M s k_{(m, n)}=1,1 \leq m \leq M, 1 \leq n \leq N\right\} \quad w=1,2,3 \ldots W
$$

$$
S c_{(w, 1.2)}=\left\{(m, n) \mid M s k_{(m, n)}=1,1 \leq m \leq M, 1 \leq n \leq N\right\} \quad w=1,2,3 \ldots W
$$

Deve-se notar que $\mathrm{W}$ é o número total de vetores espectrais de interesse, selecionado por $M s k_{(m, n)}$, a qual por ser uma matriz binária então, W é facilmente calculado por: 


$$
W=\sum_{m=1}^{M} \sum_{n=1}^{N} M s k_{(m, n)}
$$

Uma vez obtidos o subconjunto de vetores espectrais de interesse $S v_{(W, 32)}$ e suas respectivas coordenadas em $S c_{(W, 2)}$, o próximo passo é o agrupamento espectral propriamente dito.

Um agrupamento pode ser feito com base em um conjunto de referência (o qual é utilizado para treinamento de um algoritmo supervisionado). Quando não há este conjunto de referência, o caminho tomado é o uso de um algoritmos não supervisionados.

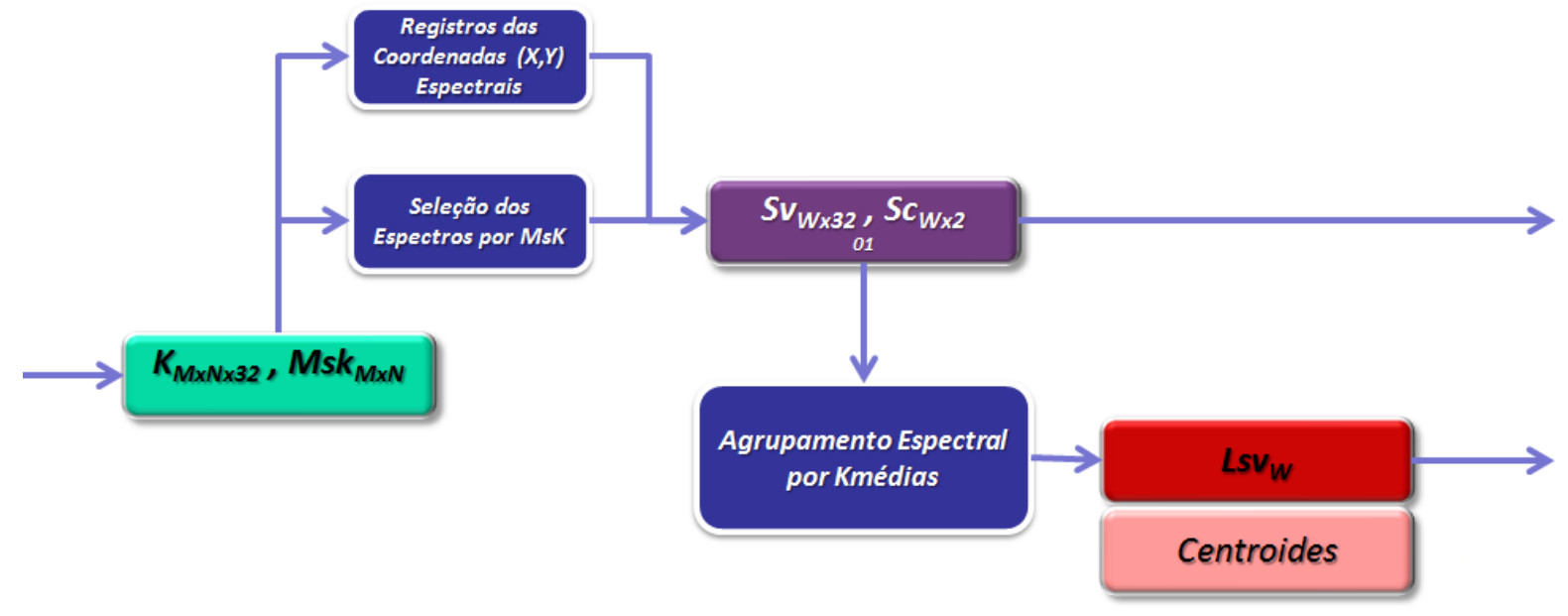

Figura 5.6-Detalhamento da etapa de segmentação espectral.

Fonte(s): Elaborada pelo autor.

A priori, o método desenvolvido ignora a composição das amostras, apenas requerendo que seja informado o quantitativo de classes $C$, esperadas dentro da amostra. Com base nessa informação um algoritmo de agrupamento não supervisionado (k-means) é usado.

O algoritmo k-means (1) foi escolhido por ser muito bem estabelecido e referenciado. Seu principal objetivo é: dado um conjunto de amostras, agrupá-las nos $C$ subconjuntos numericamente informados, usando como critério, a proximidade de cada vetor espectral, em relação aos centroides calculados interativamente (Figura 5.7). No final do processo, para cada vetor de $S v_{(W x 32)}$, é designado um rótulo $L=1,2, \ldots, C$ pela matriz $L S v_{(W)}$, gerada por:

$$
\left\{L S v_{(W)}, \text { Centroides }\right\}=k m e a n s\left(S v_{(W x 32)}, C\right), \text { para } 2 \leq C \leq W
$$

Assim, através de k-means, cada vetor de $S v_{(W x 32)}$ tem seu respectivo rótulo $L$ relacionado por $L S v_{(W)}$. Outro resultado desse agrupamento é o conjunto composto pelos $C$ Centroides 
que representam os espectros médios do número das $C$ classes espectrais contidas na amostra. Finalizada a execução deste módulo, é possivel passar para a última etapa do método: o de mapeamento e visualização.

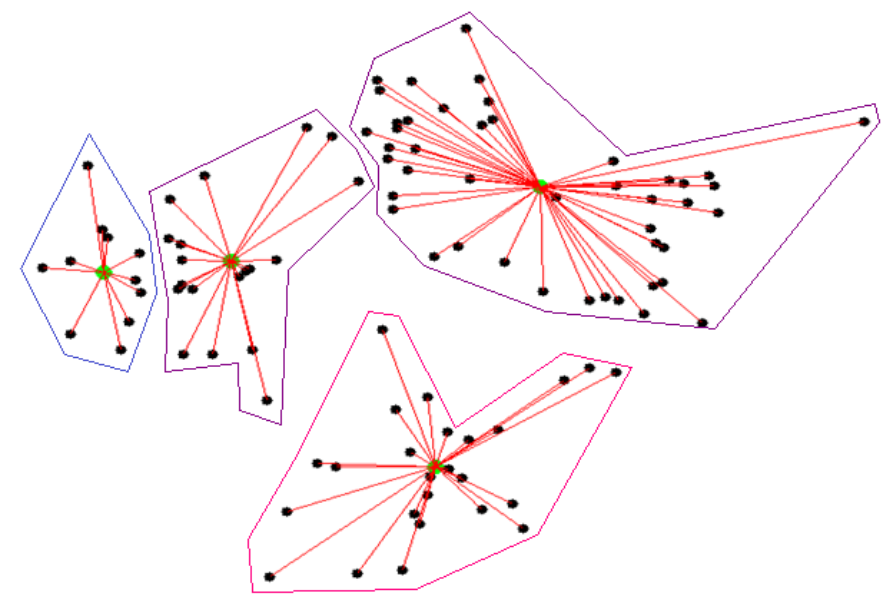

Figura 5.7 - Exemplificação de agrupamento por K-means cujos centróides no método apresentado representam o espectro médio de cada grupo.

Fonte(s): Elaborada pelo autor.

\subsection{Mapeamento e Visualização}

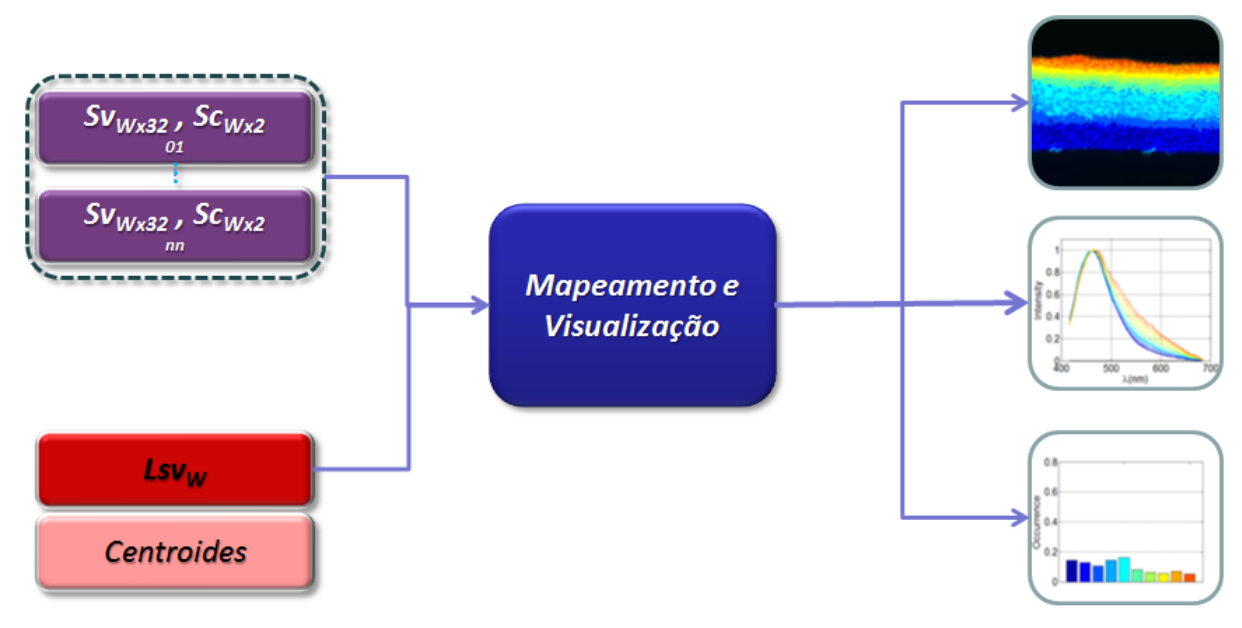

Figura 5.8-Diagrama das etapas de mapeamento e visualização.

Fonte(s): Elaborada pelo autor.

A Figura 5.8 ilustra o processo de mapeamento e visualização. Essa etapa é responsável por: gerar o mapeamento espectral com base na imagem da amostra; apresentar as curvas espectrais obtidas pelo processo de segmentação por agrupamento e gerar o histograma de 
ocorrência das classes espectrais presentes na amostra. O ponto chave desta etapa é a definição da paleta de cores, utilizada para inter-relacionar os gráficos de: mapeamento espectral, curvas espectrais e histograma de ocorrência.

O diagrama da Figura 5.9 mostra, de forma detalhada, o uso dos vetores $S c_{(W x 2)}, L S v_{(W)}$ e Centroides, na etapa de mapeamento espaço-espectral.

Pode-se observar que o módulo de definição da paleta de cores é fundamental para os outros três módulos, que somente podem ser executados, após a definição da paleta de cores $P\left(C m_{\lambda}(L)\right)$.

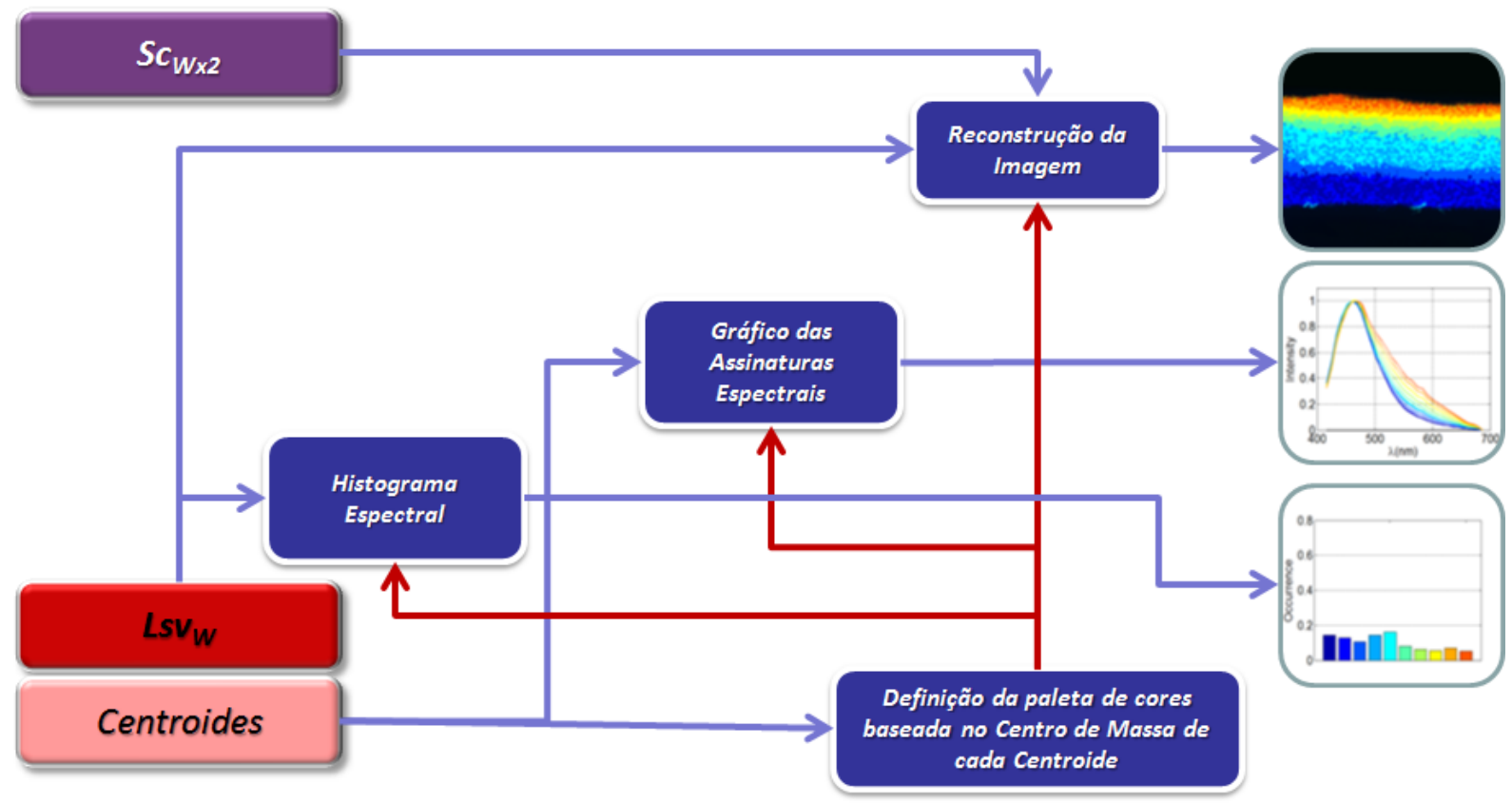

Figura 5.9-Diagrama detalhado do processo de mapeamento e visualização.

Fonte(s): Elaborada pelo autor.

Conforme apresentado em capítulo anterior, o método de coloração utilizado pelos softwares proprietários de microscópios confocais não contribui para a real visualização dos espectros presentes na amostra. Assim, buscou-se utilizar um critério que determinasse uma relação entre uma paleta de cores visualmente diferenciável e o conjunto de espectros obtidos pelo método. Na busca desse critério, focou-se no uso de uma característica física mensurável, da assinatura espectral, a fim de garantir uma uniformidade em sua aplicação e, que fosse significativamente discrepante. Várias características foram testadas sem sucesso, tais como: cálculo da energia da assinatura espectral, comprimento de onda de intensidade máxima(picos da assinatura) e, a variação da intensidade de um comprimento de onda, previamente selecionada. Por fim, notou-se que uma característica bastante observada e considerada, ao se analisar em assinaturas espectrais, é o seu deslocamento em relação aos extremos do espectro 
visível( entre 400nm e 700nm). Esse parâmetro mostrou-se bastante consistente na atribuição de cores, pois o distanciamento em relação ao extremo de $400 \mathrm{~nm}$ do espectro visível é uma característica mensurável e pode ser obtida, medindo-se as distâncias do centro de massa(em função do comprimento de onda $\lambda$ ), de cada assinatura espectral, dado por:

$$
C m_{\lambda}(L)=\frac{\sum_{\lambda=400 \mathrm{~nm}}^{700 \mathrm{~nm}} \lambda \cdot I(\lambda)}{\sum_{\lambda=400 \mathrm{~nm}}^{700 \mathrm{~nm}} \lambda}
$$

sendo, $I(\lambda)$ a intensidade do espectro com relação a $\lambda$.

Assim, uma paleta de cores $P\left(C m_{\lambda}(L)\right)$ é criada, garantindo-se uma grande discrepância de cores entre as assinaturas, ao atribuir a cor azul para a assinatura espectral mais próxima da extremidade dos $400 \mathrm{~nm}$ e a cor vermelha para a assinatura mais distante. Para as assinaturas espectrais intermediárias, são aplicadas cores na sequência do espectro visível, do azul para o vermelho, tal que se mantenha uma equidistância entre essas, considerando-se a ordem crescente da distância dos centro de massa das assinaturas espectrais em relação ao extremo do espectro de $400 \mathrm{~nm}$.

Exemplo: aplicando-se o método desenvolvido em uma imagem multiespectral e, definindose o número de cinco grupos espectrais a serem mapeados, teremos para a assinatura que estiver mais próxima ao extremo de $400 \mathrm{~nm}$, a atribuição da cor azul e para o espectro mais distante a cor vermelha. Para as assinaturas, que ficaram entre essas duas assinaturas, são atribuídas cores intermediárias tal que estas sejam equidistantes entre si, a fim de garantir uma boa visualização no mapeamento dos grupos espectrais na imagem da amostra(Figura 5.10). Deve-se notar que o número de cores criado na paleta será o mesmo número de assinaturas espectrais obtidas pelo método.

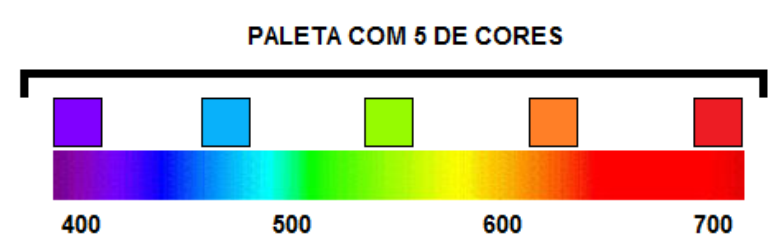

Figura 5.10 - Paleta de cores gerada para um conjunto de cinco assinaturas espectrais. Deve-se notar que há uma equidistância entre as cores, para garantir uma alta discrepância de cores.

Fonte(s): Elaborada pelo autor.

Assim, com os vetores $S c_{(W x 2)}, L S v_{(W)}$, Centroides e $P\left(C m_{\lambda}(L)\right)$ torna-se possível a reconstrução das imagens de mapeamento espectral, visto que cada pixel está associado a uma cor, a qual está relacionada a um espectro de um gráfico de assinaturas espectrais e dessas tem-se as respectivas ocorrências na amostra em estudo. 


\subsubsection{Comparação do método aplicado nos arquivos RGB e LSM, com o resultado de kmeans em RGB}

As imagens apresentadas pelos softwares de microscópios confocais, tem como base a conversão dos vetores espectrais, para o espaço de cores CIE RGB. À grosso modo, tem-se uma redução de dimensionalidade de trinta e dois canais, para apenas três (RGB). Assim, para demonstrar a precisão do método e a influência da redução da dimensionalidade, um teste comparativo foi realizado.

Em um conjunto de imagens RGB, geradas pelo software do microscópio confocal, foi aplicado um algoritmo de agrupamento não supervisionado (kmeans), gerando resultados de mapeamento denominados de "'RGB+kmeans"'. Posteriormente, nessas mesmas imagens RGB e em seus respectivos arquivos multiespectrais(LSM), aplicou-se o método proposto, gerando-se os respectivos grupos de resultados "'RGB+Método"' e "'LSM+Método"'. Por uma questão de critérios de comparação, definiu-se para todos esses testes o número de cinco agrupamentos espectrais e um mesmo conjunto de cinco cores. Nos parágrafos seguintes, cada teste é descrito e discutido. Os grupos de resultados citados, estão arranjados em colunas e, são mostrados na Figura 5.11.

Os resultados da aplicação do algoritmo de agrupamento kmeans, nas imagens RGB, são mostrados na coluna "RGB+kmeans"' da Figura 5.11. Este procedimento não foi antecedido por nenhum outro tratamento das imagens e não foi adotado nenhum critério quanto à definição de cores, sendo utilizada a sequência do espectro visual (do azul para o vermeIho), à medida que os agrupamentos são formados. É possível notar, nas imagens da coluna " 'RGB+kmeans"' da referida figura, a formação de regiões grosseiramente segmentadas, principalmente as imagens correspondentes às linhas A, C, D e E - além do uso de cores, sem um padrão claro.

A coluna " 'RGB+Método" ' foi obtida de imagens RGB processadas por todas as etapas do método proposto. Isto foi possível graças à criação de uma estrutura de arquivo multiespectral (réplica do formato LSM), que recebeu os respectivos canais dos arquivos RGB. Esta estrutura de arquivo LSM teve seus trinta e dois canais completamente zerados, com exceção dos canais $417 \mathrm{~nm}$ (canal 1), 548nm(canal 16) e $687 \mathrm{~nm}$ (canal 32), que receberam respectivamente os canais azul, verde e vermelho do arquivo RGB. Este artifício garantiu que a imagem RGB fosse processada da mesma forma que os arquivos multiespectrais (LSM), com a diferença da " 'assinatura espectral"' ser composta pelos três canais RGB, ao invés dos trinta e dois. Os resultados obtidos podem ser vistos na Figura 5.11. 
(A)
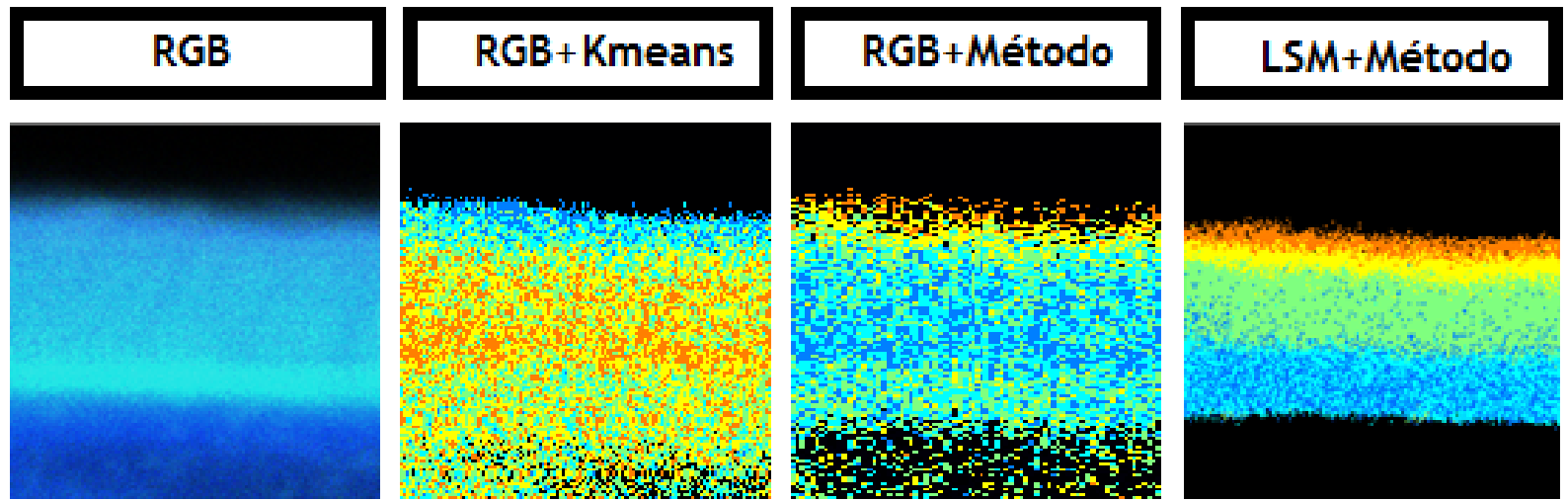

(B)
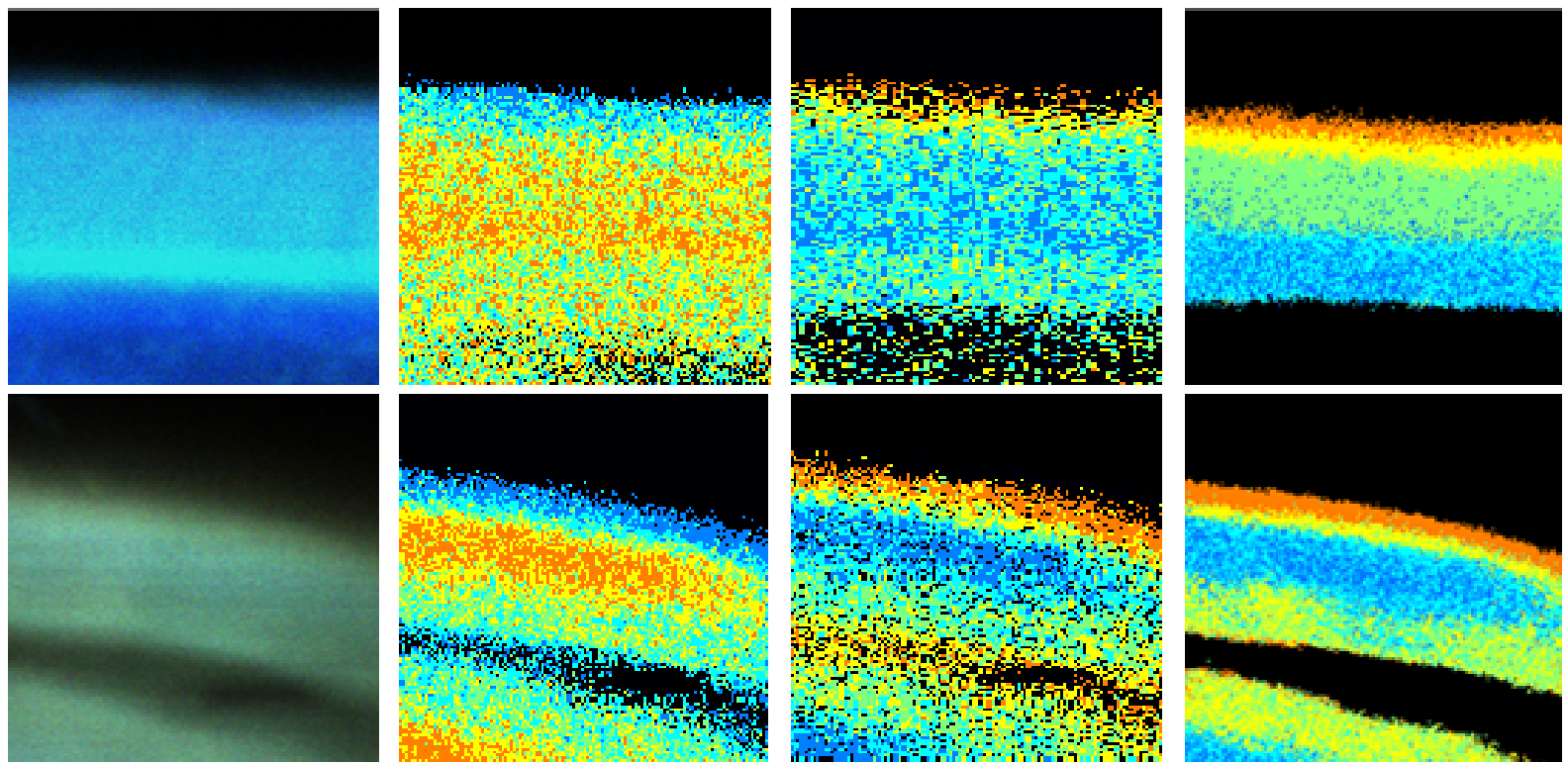

(C)
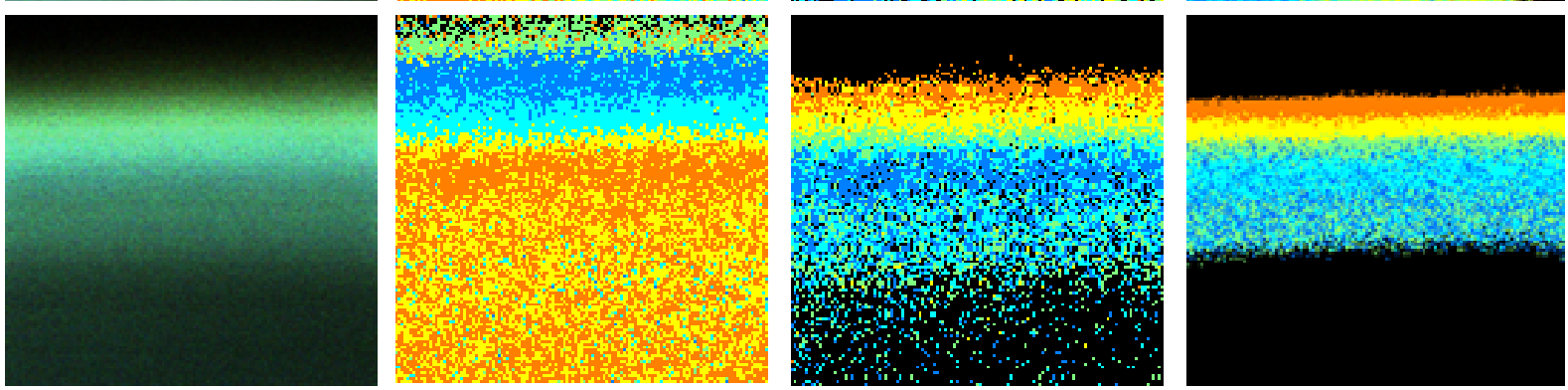

(D)
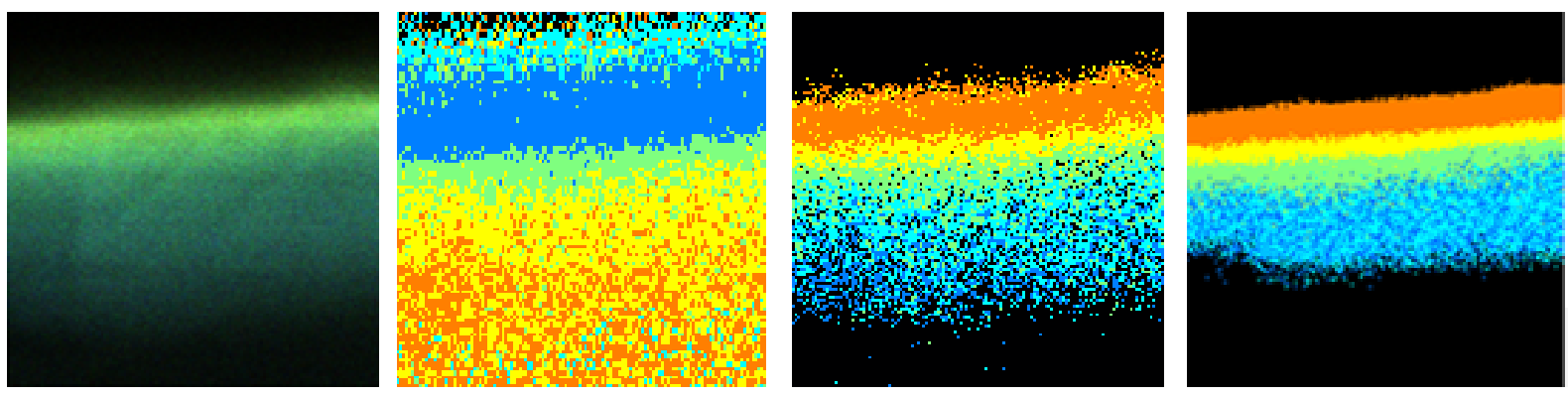

(E)
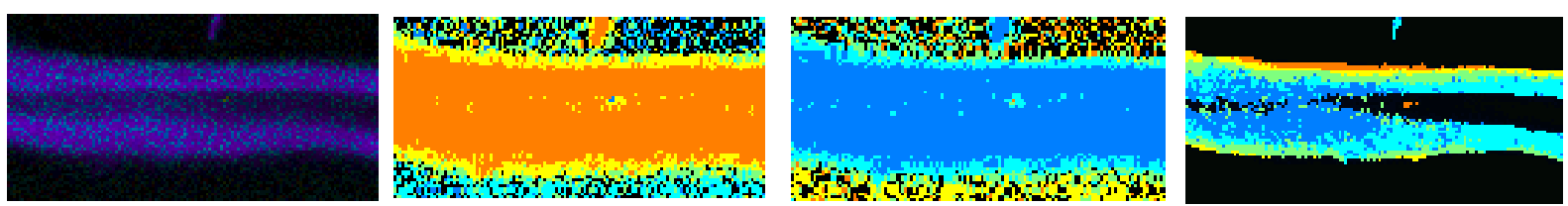

Figura 5.11 - Colunas: RGB - geradas pelo microscópio; RGB+Kmeans - imagens RGB com aplicação de kmeans; RGB+Método - imagens RGB processadas pelo método e; coluna LSM+Método - arquivos multiespectrais processados pelo método. As linhas de $A-E$ correspondem à células de cana-de-açúcar : (A) parede celular in natura; (B) parede celular tratada com $\mathrm{H}_{2} \mathrm{SO}_{4}$; (C) parede celular tratada com NaHO 0.5\%; (D) parede celular tratada com $\mathrm{NaOH} 2.0 \%$ e; (E) célula completa de fibra de cana-de-açúcar.

Fonte(s): Coluna RGB, COLLETA et al. (71); demais colunas elaboradas pelo autor. 
Um ponto relevante deve ser observado: o mapeamento baseado em imagens RGB não permite obter uma assinatura espectral completa, em consequência da redução de dimensionalidade para o formato RGB. Apesar disto, graças ao método e aos cuidados tomados na transferência das camadas $R, G$ e $B$ para os canais de comprimento de onda aproximadamente correspondentes, na estrutura LSM, foi possível um mapeamento coerente com relação à segmentação das regiões e no ordenamento da paleta de cores - ordenamento que teve como referência o centro de massa da "'assinatura espectral"', composta por três canais. As imagens das linhas A a E (coluna " 'RGB+Método" da Figura 5.11) mostram uma sensível melhora na definição de seus limites, mesmo apresentando um detalhamento ainda grosseiro. O uso da paleta de cores indica coerentemente os deslocamentos espectrais, em cada região, refletindo os estados de aglomerados de lignina em cada amostra - tal questão será melhor abordada no Capítulo 6.

A precisão espacial e espectral somente é obtida com a aplicação direta do método sobre os arquivos multiespectrais (arquivos LSM). A coluna "'LSM+Método"' mostra claramente essa qualidade e precisão, refletidas na definição dos limites das regiões segmentadas e mapeamento de cores - observáveis principalmente na imagem da linha $E$ da referida coluna.

Frente ao que foi exposto, é nítida a coerência e potencial do método proposto e a importância de seu uso direto em arquivos de imagens multiespectrais, ao invés de imagens RGB, que, embora permita agrupamentos semelhantes, não os obtêm com a mesma qualidade, além de não permitir a extração das respectivas assinaturas espectrais completas.

\subsubsection{Mapeamento simultâneo de múltiplas imagens}

Um desdobramento do método muito relevante e que ofereceu outro recurso inédito é a possibilidade do mapeamento simultâneo de múltiplas imagens multiespectrais, permitindo uma análise espectral comparativa entre amostras distintas, coletadas em tempos distintos ou que passaram por tratamentos distintos. O mapeamento múltiplo simultâneo indica ponto a ponto a presença ou não de espectros em múltiplas amostras e a ocorrência desses espectros, pelo histograma. De forma geral, o processo consiste em aplicar a etapa de segmentação espectral por agrupamento simultaneamente ao conjunto de imagens multiespectrais que já passaram pelo processamento numérico. Também é necessário um controle diferenciado na reconstrução dos gráficos espectrais, histogramas e principalmente das imagens das amostras mapeadas. A Figura 5.12 mostra um exemplo da aplicação deste recurso em amostras de um tipo de fibra vegetal, que passaram por tratamentos químicos distintos. Deve-se notar que todas as amostras mapeadas estão sob a mesma paleta de cores, permitindo a comparação. 
A Figura 5.13 mostra o diagrama do processo de geração dos dois tipos de mapeamento de imagem multiespectral: o modo individual, que compreende os blocos localizados no centro do diagrama, partindo-se da aquisição da imagem, seguindo para o conjunto de blocos à direita do diagrama e o modo de mapeamento simultâneo múltiplo, que compreende o fluxo do diagrama que parte do mesmo ponto do mapeamento individual e segue para os blocos à esquerda do diagrama.

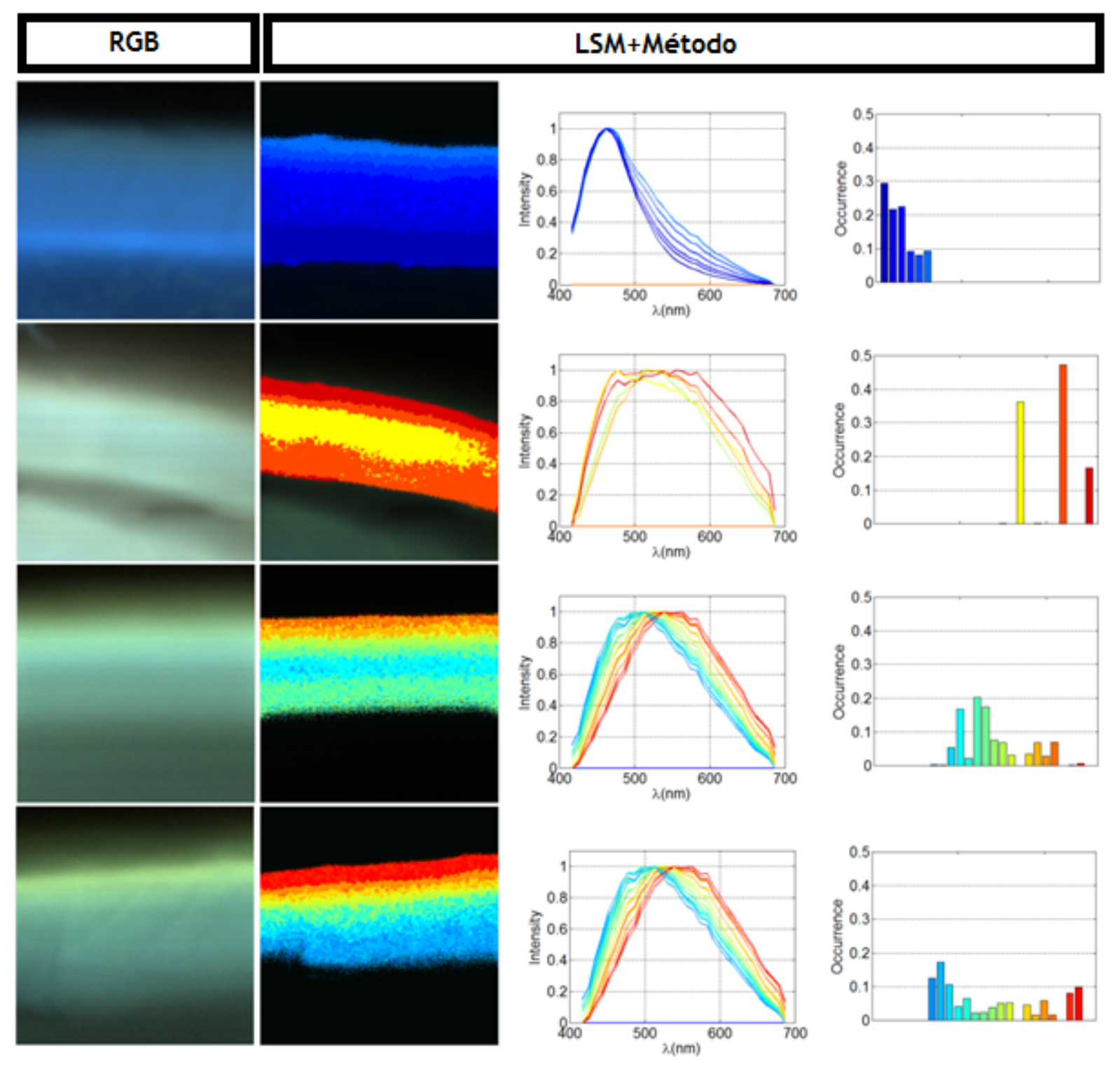

Figura 5.12 - Aplicação simultânea, do método de mapeamento espaço-espectral, em múltiplas imagens multiespectrais.

Fonte(s): Coluna RGB, COLLETA et al. (71); demais colunas elaboradas pelo autor.

No modo de mapeamento individual, após a aquisição das imagens multiespectrais (arquivos LSM ) cada uma passa pelo processamento numérico que dá origem aos arquivos de formato FDS. Nesses são aplicados máscaras binárias e o algoritmo k-means (individualmente) 
para a realização do agrupamento espectral, resultando em um arquivo de formato EXP. Desse tipo de arquivo é possível obter as curvas espectrais, suas respectivas posições na imagem e a ocorrência relativa de cada espectro contido na amostra, por meio de um histograma.

O modo de mapeamento simultâneo múltiplo parte dos arquivos de formato EXP (que foram gerados de forma individual),considerando todos os vetores espectrais originais das amostras selecionadas - como se pertencessem a uma única imagem. Nesse grupo de vetores é aplicado o algoritmo k-means para o agrupamento em $\mathrm{N}$ grupos(gerando o arquivo GEXP). Após a identificação de cada vetor em seu novo grupo, o mapa espectral de cada amostra é reconstruído, sob o mesmo conjunto espectral definido pelas múltiplas imagens multiespectrais. Esse único conjunto espectral definido pelo grupo de imagens, torna possível uma análise comparativa entre as diversas amostras, pela presença ou não de determinados espectros, sua respectiva localização espacial e frequência de ocorrência. 


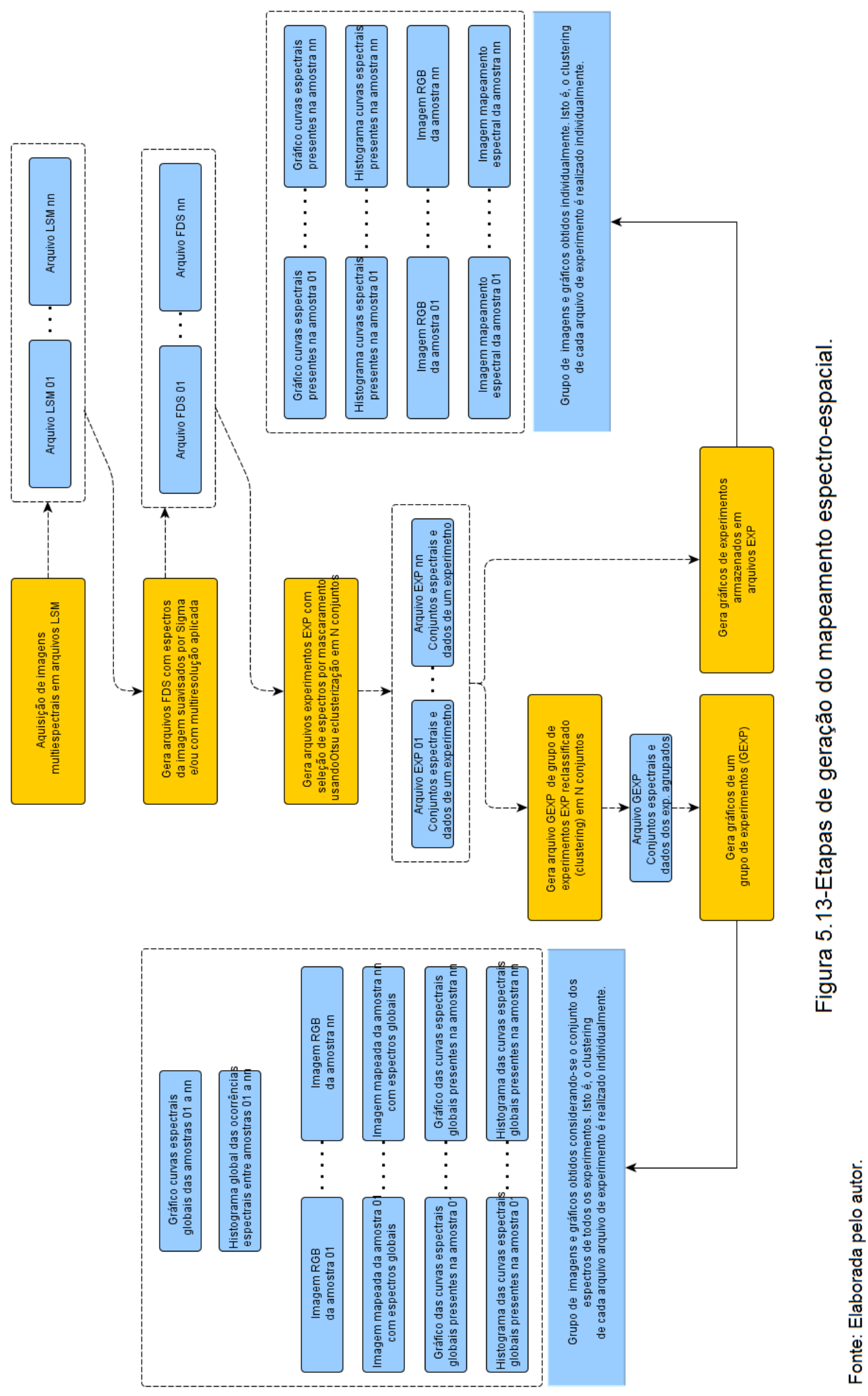




\subsection{Considerações finais}

O presente capítulo descreveu as etapas do método desenvolvido de mapeamento espaçoespectral de imagens multiespectrais. Esse método permite a caracterização de amostras de forma individual, com a caracterização das assinaturas espectrais por meio de um classificador não-supervisionado (k-means), a determinação da posição espacial de cada espectro na imagem e a respectiva frequência de ocorrência. Também fez uma comparação entre os resultados obtidos pela segmentação (por kmeans) ,de imagens RGB, e a aplicação do método proposto sobre as mesmas imagens e seus respectivos arquivos multiespectrais(LSM). Outra propriedade descrita do método foi sua aplicação na análise de múltiplas imagens de forma simultânea, permitindo uma análise comparativa, entre amostras distintas. No capítulo seguinte são descritas aplicações na caracterização de amostras de forma individual e em grupo, e os resultados obtidos. 


\section{CAPÍTULO 6 \\ Resultados em biologia vegetal}

Neste capítulo, são mostrados os resultados obtidos pelo método desenvolvido, de mapeamento espaço-espectral, em experimentos de biologia vegetal. O equipamento utilizado e algumas informações da aplicação de microscopia confocal de varredura à laser em tecido vegetal são tratados na Seção 6.1. - especificamente relacionados à paredes celulares vegetais e cortes de estruturas foliares.

Relacionado à estrutura de paredes celulares vegetais, o método foi utilizado para mapear o comportamento de aglomerados de lignina, em imagens multiespectrais coletadas de amostras de fibras de cana-de-açúcar, após serem submetidas a diversos pré-tratamentos químicos e físicos para a extração de lignina(Seção 6.2).

$\mathrm{Na}$ análise de estruturas foliares, o método foi aplicado em imagens multiespectrais de cortes foliares, de amostras de uma espécie de jacarandá (Jacaranda caroba), com o objetivo de analisar a viabilidade do uso dessa como um indicador biológico de qualidade do ar. Também com base na análise de cortes foliares, estudou-se o uso do método desenvolvido como uma possibilidade de caracterização e identificação de espécies vegetais, utilizando o conjunto de assinaturas espectrais obtidas pelo método e suas respectivas ocorrências, dadas pelo histograma (Seção 6.4).

\subsection{Microscopia confocal de varredura à laser aplicada em biologia vegetal}

As imagens multiespectrais foram obtidas por meio do microscópio confocal de varredura a laser do Intituto de Física de São Carlos - USP (Figura 6.1), Zeiss LSM 780 com laser Coherent Chameleon (Ti:sapphire). 

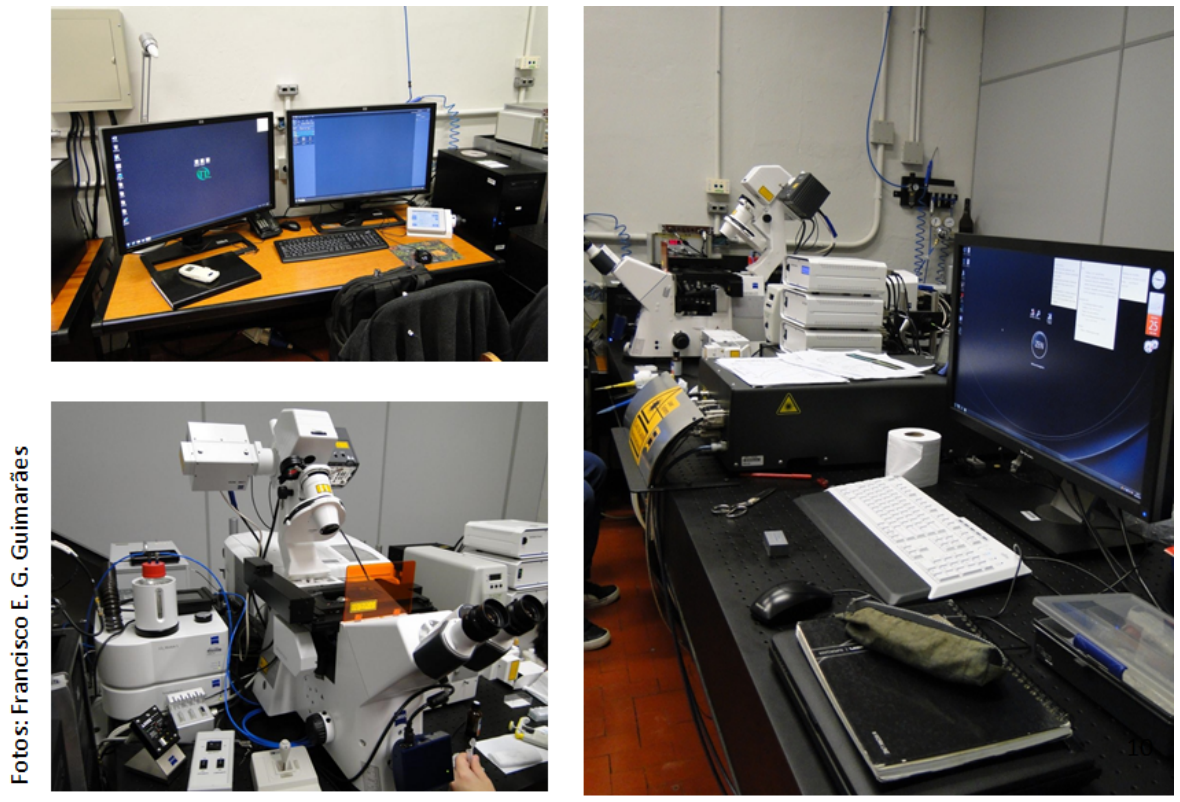

Figura 6.1-Microscópio confocal de varredura à laser do Instituto de Física de São Carlos.

Fonte(s): Francisco E. G. Guimarães *

Pela característica da microscopia confocal (já descrita em capítulo anterior) esta permite que sejam obtidos cortes dos objetos de estudos, fazendo com que o plano focal penetre no interior da amostra. Isto é, as imagens obtidas não são da superfície da amostra, mas sim do interior desta. A imagem 6.2 mostra uma sequência de cortes de células de cana-de-açúcar e as dimensões do volume ótico do ponto focal.
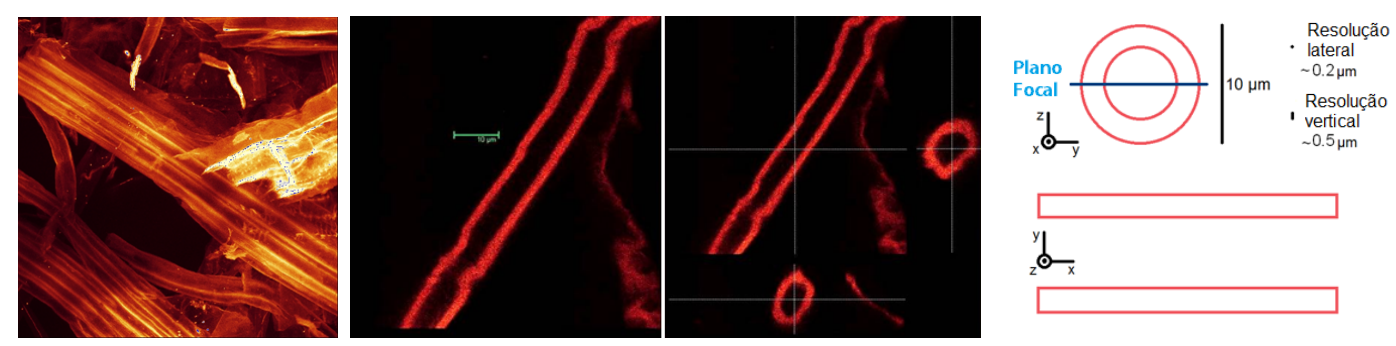

Figura 6.2 - $\quad$ Imagens de cortes de fibras e células de cana-de-açúcar e o diagrama e das dimensões do volume ótico do ponto focal.

Fonte(s): Francisco E. G. Guimarães*.

A imagem da Figura 6.2-A mostra um feixe de células de cana-de-açúcar agrupadas. As imagens 6.2-B e C apresentam células de cana-de-açúcar, cujas linhas paralelas são as paredes celulares resultante de um corte longitudinal e as duas circunferências que surgem em 6.2-C, correspondem a um corte transversal de duas células de cana-de-açúcar. A imagem 6.2-D mostra as dimensões do volume ótico, do ponto focal, do microscópio utilizado.

\footnotetext{
*Imagens gentilmente cedidas por Francisco E. G. Guimarães.
} 
Nas seções seguintes são mostradas imagens com cortes semelhantes, mas com o respectivo mapeamento espectral. No caso das imagens de microscopia mostradas na Figura 6.2-A-C, estas foram obtidas em função da emissão por fluorescência da lignina. Na imagem obtida foi aplicada cor falsa, que correspondente à variação de intensidade.

Em imagens multiespectrais de cortes foliares, há a presença de diversas substâncias que emitem suas assinaturas espectrais. A Figura 6.3-a mostra três assinaturas de emissão por fluorescência, muito comuns em uma folha, a lignina e as clorofilas a e b. Presente na constituição da parece celular vegetal, a lignina pode ser vista como os ossos que sustenta a estrutura de uma planta. É muito presente em caules e galhos e também em folhas, principalmente no sistema de venação(xilema, floema, nervura secundária - Figura 6.3-b).

A clorofila, a e b, responsáveis pela fotossíntese, são encontradas nas células do parênquima paliçádico e também no parênquima esponjoso. São facilmente identificáveis por se apresentarem como pequenos discos de coloração verde, quando visto por microscopia ótica, embora emitam, por fluorescência, comprimentos de onda na faixa do vermelho(Figura 6.3-b).

Essas substâncias estão presentes em qualquer vegetal e podem ser referências nas imagens de mapeamento espectral, obtidas pelo método. Principalmente a lignina, em que neste trabalho, o método de mapeamento espaço-espectral é aplicado em imagens multiespectrais de amostras de bagaço de cana-de-açúcar.

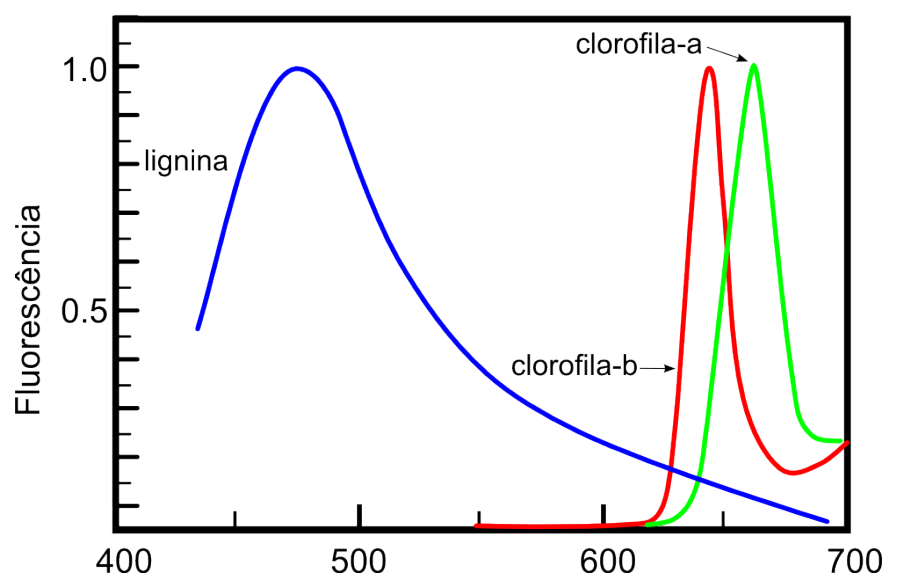

Figura 6.3-Assinaturas espectrais que podem ser encontradas em folhas. 


\subsection{Resultados de análises de pré-tratamentos de bagaço de cana-de-açúcar}

É crescente a necessidade de fontes renováveis de energia, e o etanol é uma alternativa que vem sendo adotada. No caso do Brasil, o etanol é obtido pela fermentação de açúcares extraído da cana-de-açúcar. Uma maneira de aumento de produção de etanol, sem que haja aumento na área de plantio, é a produção de etanol a partir do próprio bagaço de cana-de-açúcar.

Esse tipo de etanol, chamado de etanol de segunda geração, tem por base a fermentação de açúcares obtidos pela quebra de celulose e hemi-celulose(Figura 6.4) extraídos da parede celular do bagaço de cana. Entretanto, a extração de celulose e hemi-celulose é impedida pela presença da lignina. Por ter a função estruturante da célula, a parede celular possui sua rigidez granças a presença da lignina que mantém fortemente presos celulose e hemi-celulose, formando a parede celular vegetal. Logo, faz-se necessário que o bagaço passe por um prétratamento, para que o máximo de lignina seja removida, liberando o acesso de enzimas que quebrarão a celulose e hemi-celulose em açúcares.

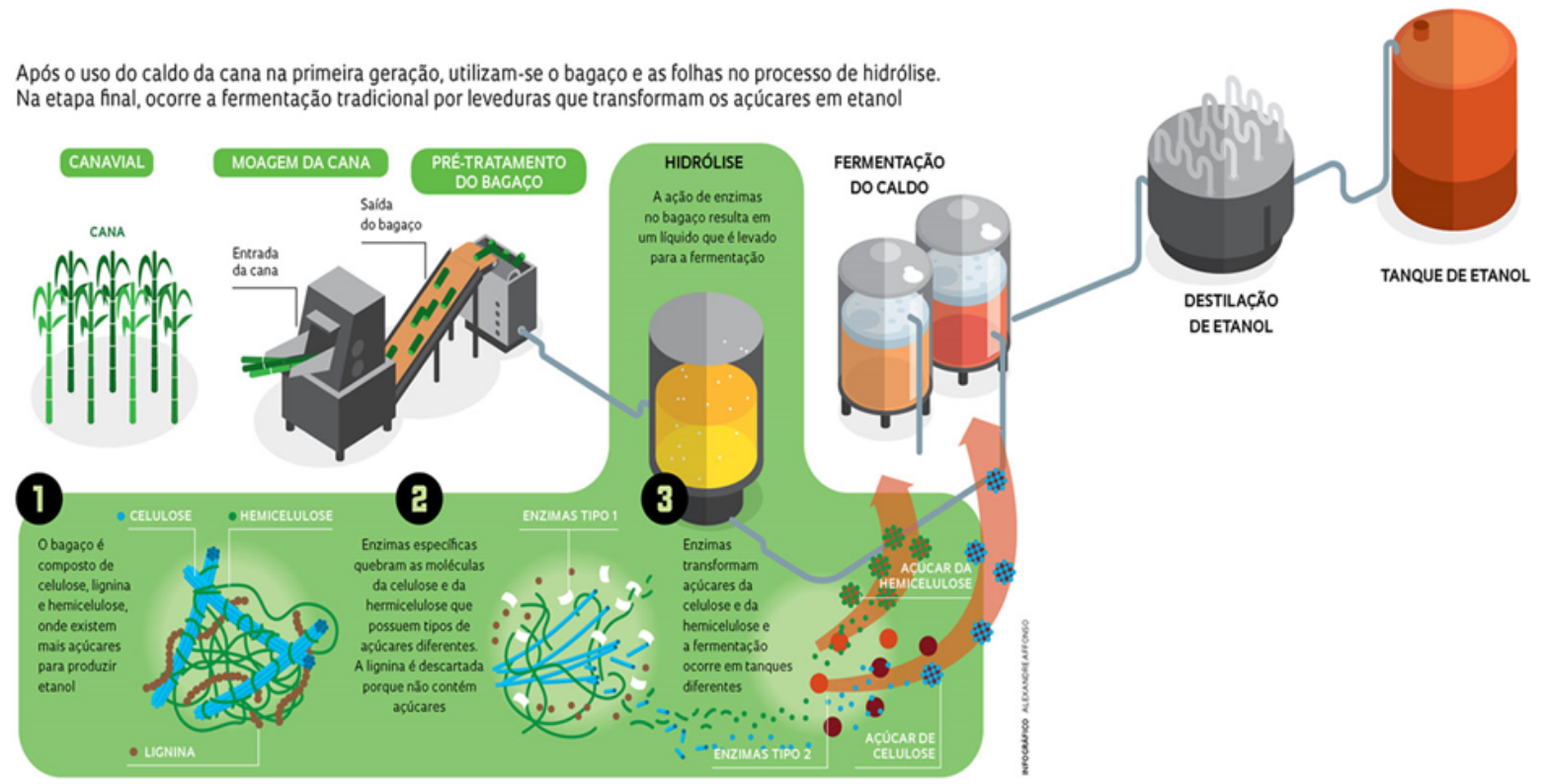

Figura 6.4-Produção de etanol de segunda geração.

Fonte(s): DE OLIVEIRA (88).

Os resultados obtidos pelo método de mapeamento espaço-espectral, desenvolvido e apresentado neste trabalho, mostram o comportamento dos agregados de lignina, de amostras que foram submetidas à pré-tratamentos químicos e físicos. Mas antes, torna-se necessário entender que informações uma assinatura espectral pode fornecer, referente à lignina contida 
em uma parede celular vegetal.
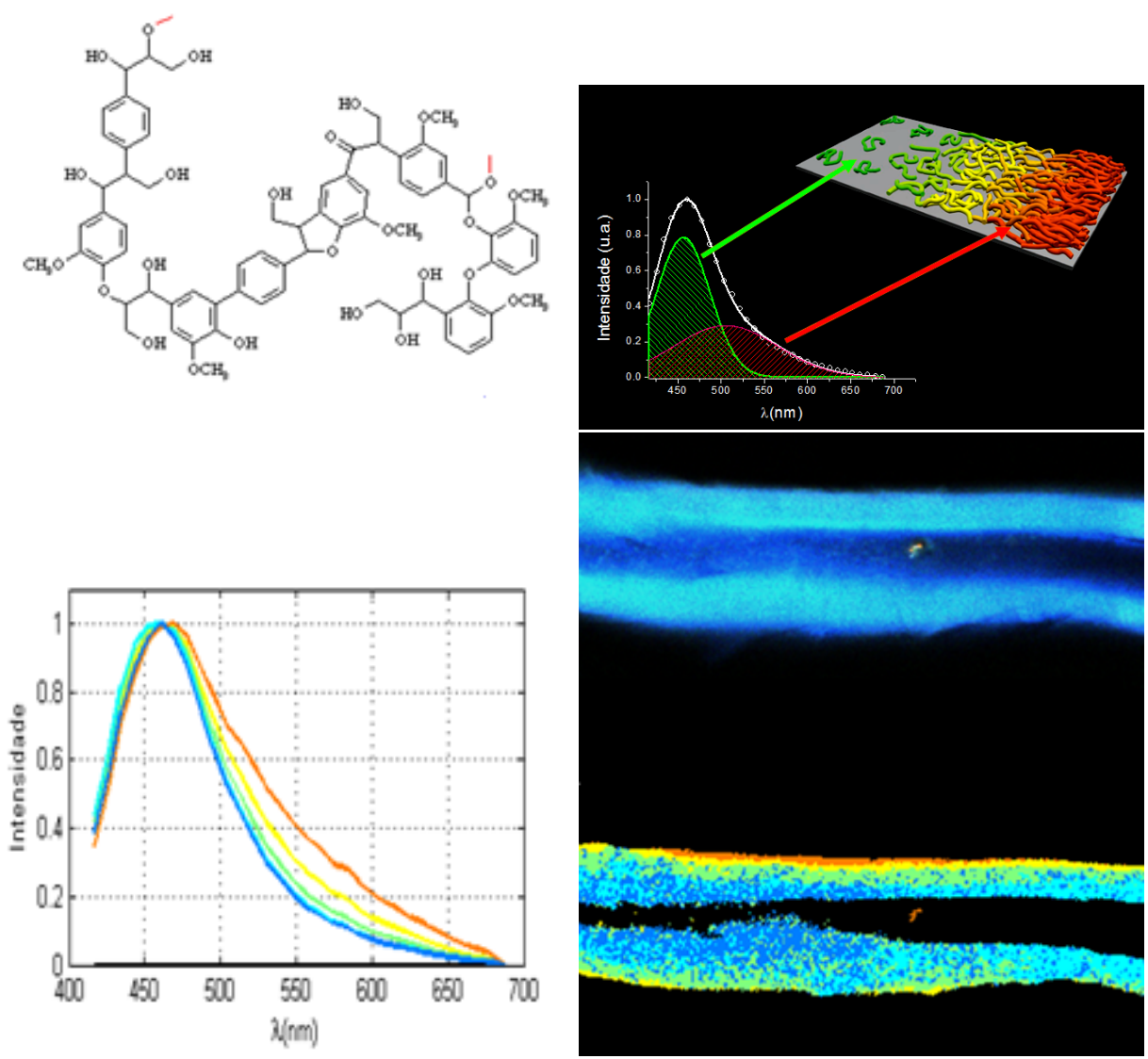

Figura 6.5 - (a) Molécula de lignina; (b) agregados de lignina e respectivos espectros; (c) celula vegetal obtida por CLSM e a mesma imagem após aplicação do método de mapeamento; (d) e, respectivos espectros mapeados (c).

Fonte(s): (a) e (b) Fracisco E. G. Guimarães ${ }^{\dagger}$; (c) Fracisco E. G. Guimarães e o próprio autor; (d) Elaborada pelo autor.

A Figura 6.5-A mostra a estrutura molecular da lignina. Sua influência na formação dos arranjos rígidos com a celulose e hemi-celulose deve-se ao seu estado de agregação. Quanto maior for a agregação de moléculas de lignina, em uma região, maior é a dificuldade de acesso de enzinas, que quebrarão a celulose e hemi-celulose em açúcares. A assinatura espectral da lignina, por fluorescência, pode informar o estado de agregação desta, em função do deslocamento de sua assinatura espectral de emissão. Quanto mais deslocada para o vermelho a assinatura espectral da lignina estiver, maior é o seu agregamento, no local de onde foi emitida tal assinatura, o que indica uma maior dificuldade de ação de enzimas.

Esse deslocamento para o vermelho está relacionado com a dissipação da energia absorvida pelo laser de excitação. Antes de ocorrer a emissão por fluorescência, parte da energia

\footnotetext{
†Imagem gentilmente cedida por Francisco E. G. Guimarães.
} 
sofre conversão interna. Isto é, parte da energia se dissipa entre as outras moléculas de lignina agregadas. Assim, quanto maior a agregação, maior o número de moléculas de lignina agrupadas, o que implica em uma maior dissipação de energia. A energia restante (que será menor) é convertida em uma emissão, com um deslocamento de espectro para o vermelho. Em situação inversa, quando a agregação é mínima, significa que a perda de energia por conversão é pequena, fazendo com que a emissão tenha seu espectro, com pouco deslocamento para o vermelho, tendendo ficar mais próximo à faixa do azul. A Figura 6.5-B ilustra esses deslocamentos, relacionando-os com o estado de agregação das moléculas de lignina.

Uma vez compreendido o comportamento da assinatura espectral da lignina, é possível analisar a Figura 6.5-C, na qual são mostradas duas imagens de uma mesma amostra multiespectral, de uma célula de bagaço de cana. A primeira imagem, gerada pelo software proprietário do microscópio utilizado, fez uso da conversão das assinaturas multiespectrais para cor, o que resultou em uma massa azulada não permitindo notar qualquer variação espectral pela cor.

A imagem logo abaixo, no entanto, é o resultado da aplicação do método desenvolvido, que permite identificar as regiões de variação espectral pixel a pexel. Deve-se também notar que a Figura 6.5-D traz as respectivas assinaturas espectrais, que estão relacionadas com cada pixel da imagem de mapeamento ( Figura 6.5-C), em função da paleta de cores. Ao se observar a Figura 6.5-C, é possível notar a formação de um gradiente espectral decrescente de agregação, se percorrido no sentido da região da borda externa para a borda interna, como é indicada pelas assinaturas espectrais. Assim, pode-se observar uma estratificação da lignina, normalmente maior, na borda externa da parede celular. A constatação desse resultado é de extrema importância e será melhor discutido com o auxílio da Figura 6.6. 

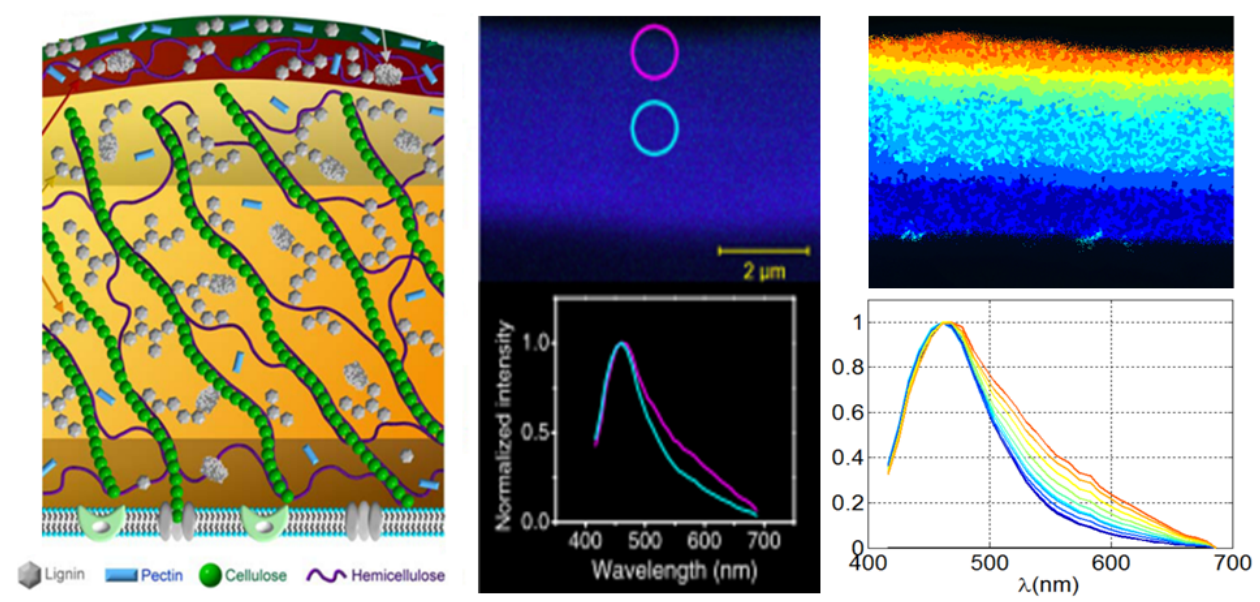

Figura 6.6 - (a) modelo conhecido de segmentação da lignina na parede celular; (b) imagem obtida por software proprietário do microscópio confocal e respectivas assinaturas espectrais por região e; (c) imagem obtida pelo método de mapeamento desenvolvido, aplicado na imagem multiespectral da amostra.

Fonte(s): (a) Adaptada de ACHYUTHAN et. al (73); (b) COLLETA et al.(71); (c) Elaborada pelo autor.

A Figura 6.6-A ilustra a estratificação da lignina em uma parede celular, já muito bem conhecida pela literatura. A borda inferior do desenho, corresponde à borda interna de uma parede celular e, a borda superior, à borda externa. É possível também observar a diferença de concentração de lignina entre essas duas bordas, formando um gradiente. Isto pode ser observado pelo método convencional de obtenção de espectros, na Figura 6.6-B. Como pode ser notado, os softwares convencionais de obtenção de assinaturas espectrais exigem que uma localização e área da região sejam definidas, para que o respectivo espectro médio seja obtido. No caso dessa figura, duas regiões da imagem foram selecionadas e as suas respectivas assinaturas espectrais, foram mostradas logo abaixo.

Aplicando-se o método desenvolvido, na mesma imagem multiespectral da amostra da Figura 6.6-B, foi possível obter como resultado, o mapeamento apresentado na Figura 6.6-C. Suas respectivas assinaturas espectrais estão relacionadas, pela paleta de cores, pela ordem (crescente) de distância de cada espectro, em relação ao espectro azul (400nm), assim como aos gráficos de curvas espectrais que o acompanha. Deve-se notar que o resultado obtido não dependeu de interferência humana, na seleção de região ou área. Assim, a determinação das assinaturas espectrais não estão relacionadas a uma região específica, mas a cada pixel da imagem. 

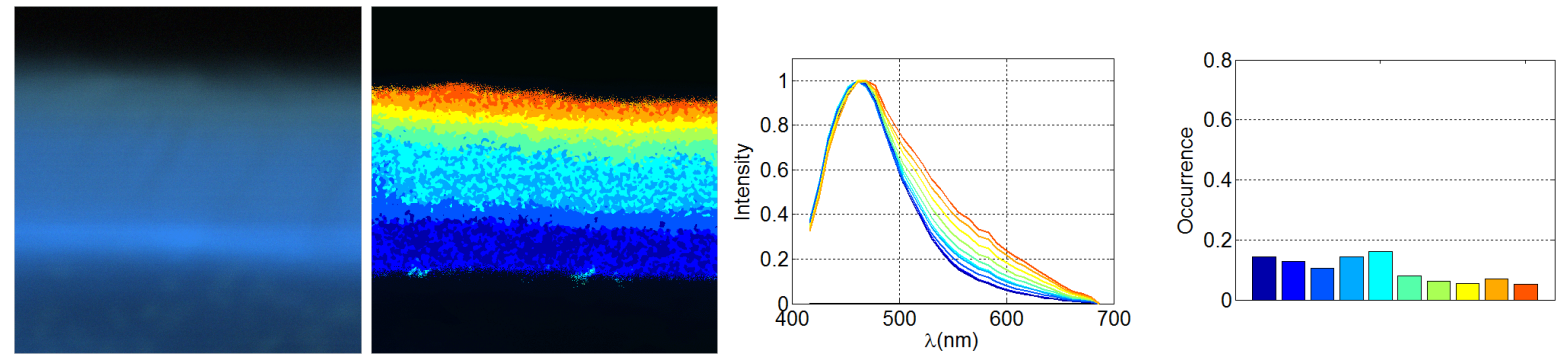

Figura 6.7 - Da esquerda para a direita: imagem obtida do microscópio sem a aplicação do método; imagem com a aplicação do método; gráfico dos espectros obtidos pelo método; histograma de ocorrência de cada espectro na imagem.

Fonte(s): esq. Francisco E. G. Guimarães ${ }^{\ddagger}$; demais imagens geradas pelo próprio autor.

A Figura 6.7 mostra a imagem gerada pelo software proprietário do microscópio, e a imagem e gráficos gerados pela aplicação do método de mapeamento espaço-espectral. Pode-se notar que, ao compararmos as imagens 6.7A e $B$, é nítida capacidade de análise fornecida pelo método. A paleta de cores permite identificar claramente as regiões de diferentes assinaturas espectrais(pixel a pixel) relacionando-as ao gráfico de curvas espectrais e ao seu histograma de ocorrência. O que facilmente se nota é a estratificação da lignina, com um menor nível de agregação na borda inferior e um maior nível de agregação na borda superior. No caso desta amostra, trata-se de uma parede celular de bagaço de cana in natura.
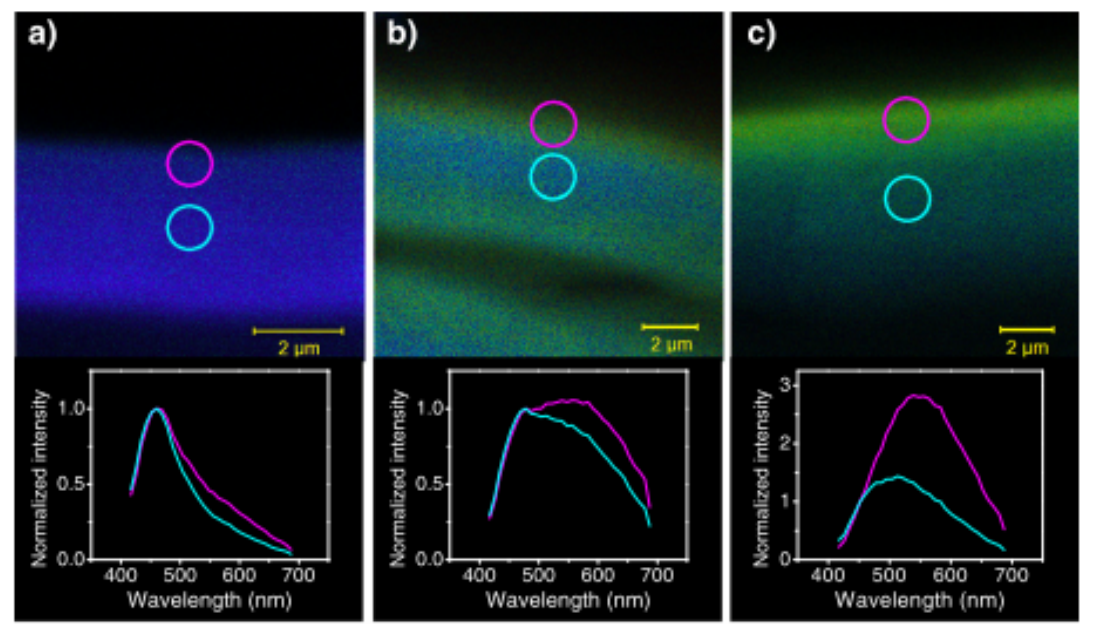

Figura 6.8 - (a) fibra de bagaço de cana não tratado; (b) bagaço tratado com $\mathrm{H}_{2} \mathrm{SO}_{4}$ a $1 \%$; (c) bagaço tratado com $\mathrm{NaOH}$ a $2 \%$.

Fonte(s): COLLETA et al. (71).

Outra aplicação do método foi realizada nos arquivos multiespectrais do experimento de Coletta e colaboradores(71), em um trabalho de colaboração conjunta. A Figura 6.8

\footnotetext{
$\ddagger$ Imagem gentilmente cedida por Francisco E. G. Guimarães
} 
mostra os resultados obtidos e publicados pelos autores, de três amostras de paredes celulares de bagaço de cana-de-açúcar, que passaram por um pré-tratamento químico. O objetivo desses tratamentos químicos é estudar o processo de extração de lignina, por tratamento de ácido e base. As referidas imagens e assinaturas espectrais foram obtidas pelo método convencional, fornecido pelo software proprietário do microscópio. Como pode ser observado, há a necessidade de seleção de regiões, com base em uma imagem resultante da transformação de assinaturas multiespectrais, para cores no sistema RGB.

A Figura 6.8-a mostra uma fibra in natura e as duas assinaturas obtidas, pelas regiões assinaladas. Como pode ser observado, há a predominância dessas assinaturas na região azul do espectro, com uma das assinaturas com um leve deslocamento em direção à região vermelha do espectro, o que indica variação de agregados de lignina, conforme comentado anteriormente. A Figura 6.8-b mostra a imagem de uma fibra, que passou por um tratamento ácido $\left(\mathrm{H}_{2} \mathrm{SO}_{4}\right)$, o qual tem por finalidade o desarranjo dos agregados de lignina(indicado pela mudança das assinaturas espectrais), como preparação de sua extração. Por fim, após o tratamento ácido, ocorre o tratamento com uma base $(\mathrm{NaOH})$ que faz a extração da lignina(Figura 6.8-c).

Os mesmos arquivos multiespectrais, do experimento anteriormente citado, foram utilizados para aplicação do método, com a adição de mais uma amostra que foi tratada com uma concentração de $0.5 \%$ de $\mathrm{NaOH}$. A Figura 6.9 mostra os resultados obtidos pela aplicação do método. É importante notar que as amostras foram processadas individualmente.

A Figura 6.9 mostra, de forma nítida e consistente, a variação de assinaturas espectrais de cada amostra. A sequência de imagens e gráficos indicados por 6.9-A, apresenta uma amostra in natura. O desarranjo causado pela solução ácida, na amostra da Figura 6.9-B, é indicada pela variação das assinaturas espectrais. Estas, tem seu alargamento na base, além de se deslocarem em direção à faixa vermelha do espectro. Uma vez desarranjadas, as moléculas de lignina podem ser removidas, por uma solução básica. Os gráficos 6.9$\mathrm{C}$ e $\mathrm{D}$, gerados pelo método, mostram nitidamente assinaturas espectrais que se deslocam em direção ao vermelho. Comparando-se os dois conjuntos espectrais, pode-se considerá-los praticamente idênticos entretanto, observando-se o mapeamento espaço-espectral, é possível notar diferenças nas espessuras das camadas dos espectros mapeados.

Observando-se o mapeamento e suas respectivas curvas espectrais da amostra da Figura 6.9C e D, o espectro mais deslocado para o vermelho é o que se encontra rente à borda externa de todos os mapeamentos, indicando um maior agregamento de lignina. Essa densidade de agregamento decresce à medida que se caminha em direção à borda interna (indicado pela coloração dos pixels e respectivas curvas espectrais). É possível notar uma espessura maior 
do espectro mais deslocado para o vermelho, o que está rente à borda externa, da amostra tratada com $2.0 \%$ de $\mathrm{NaOH}$ (Figura 6.9-D) o que é bastante coerente, pois indica que houve uma maior quantidade de lignina deslocada, tentando atravessar a borda externa da parede celular. Deve-se notar que este tipo de análise não é obtido de forma direta, por meio dos recursos atualmente oferecidos pelos microscópios confocais.

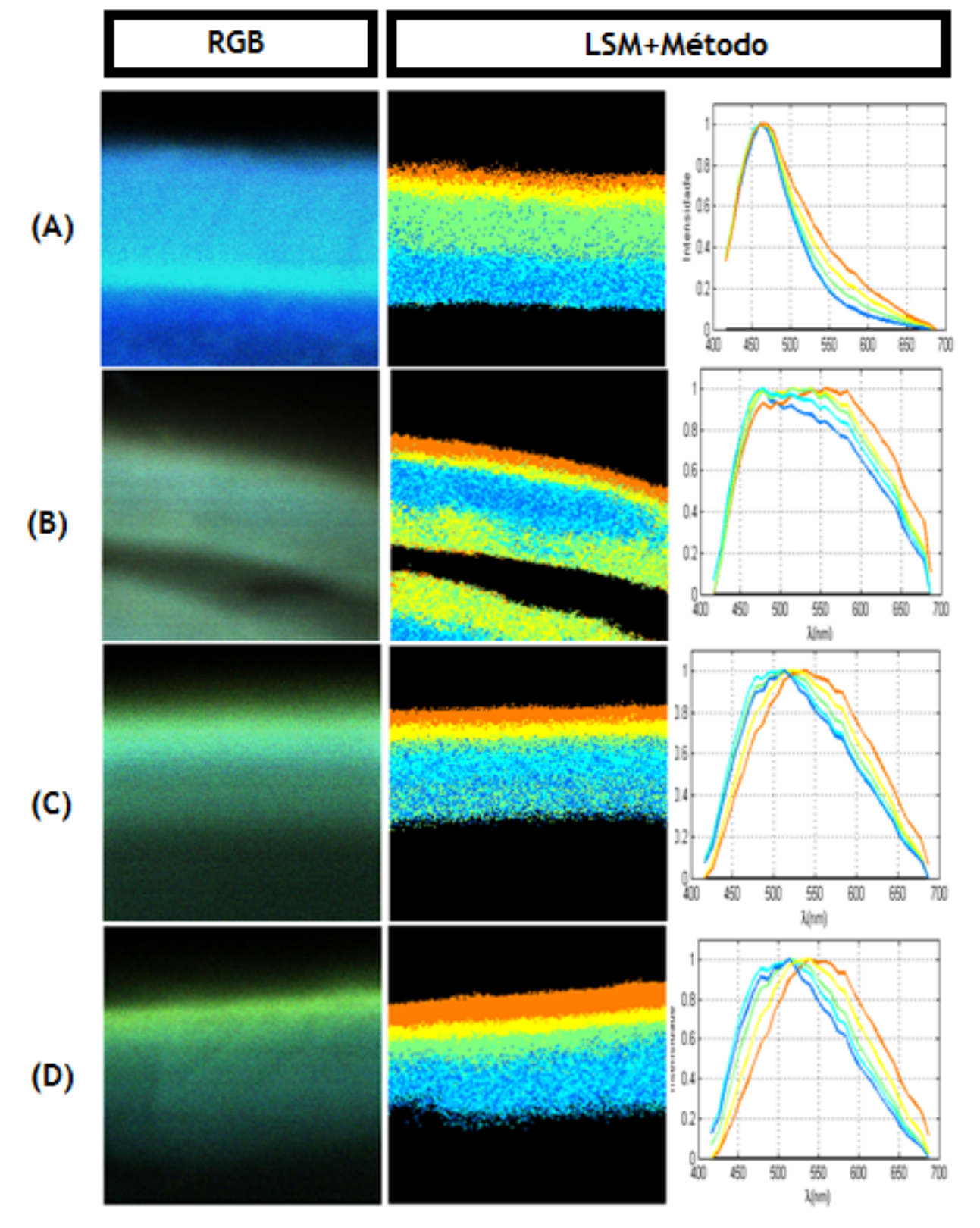

Figura 6.9 - Método de mapeamento aplicado individualmente nas amostras- segmentação em 5 grupos. Coluna RGB são imagens obtidas pelo software do microscópio; coluna LSM+Método imagens e gráficos obtidas pelo método. Linhas (a) bagaço in natura; (b) bagaço tratado com $\mathrm{H}_{2} \mathrm{SO}_{4}$ a $1 \%$; (c) bagaço tratado com $\mathrm{NaOH}$ a $0.5 \%$ e; (d) bagaço tratado com $\mathrm{NaOH}$ a $2.0 \%$.

Fonte(s): Coluna RGB COLLETA et al. (71) ; Coluna LSM+Método elaborada pelo autor. 
Outro recurso oferecido pelo método, e que permite a comparação de amostras distintas em relação a presença de assinaturas espectrais, é o mapeamento simultâneo de múltiplas imagens multiespectrais(Figura 6.10).

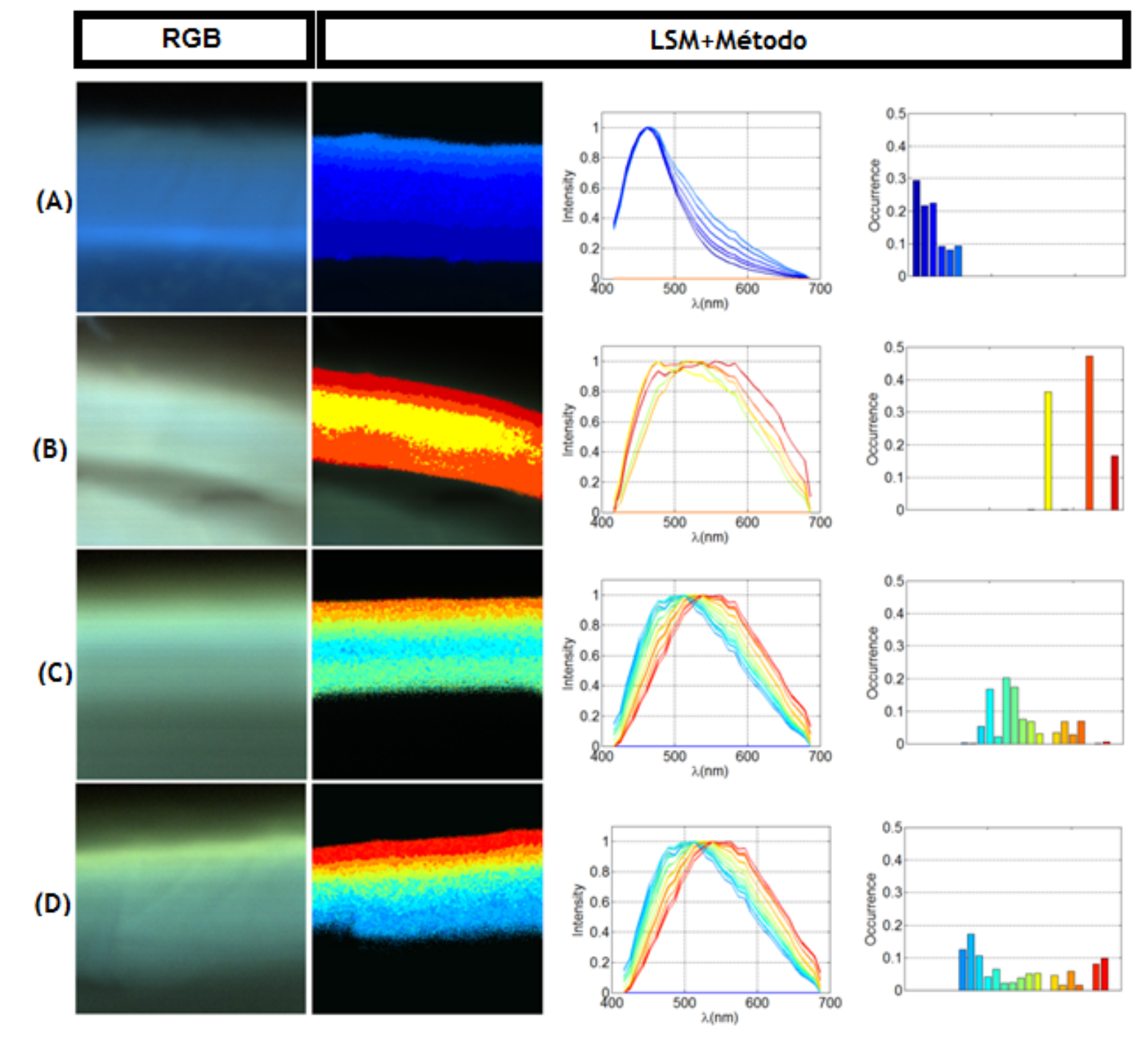

Figura 6.10 - Método de mapeamento múltiplo simultâneo, com segmentação espectral em 25 agrupamentos. Coluna RGB são imagens obtidas pelo software do microscópio; coluna LSM+Método imagens e gráficos obtidas pelo método. Linhas (a) bagaço in natura; (b) bagaço tratado com $\mathrm{H}_{2} \mathrm{SO}_{4}$ a $1 \%$; (c) bagaço tratado com $\mathrm{NaOH}$ a $0.5 \%$ e; (d) bagaço tratado com $\mathrm{NaOH}$ a $2.0 \%$.

Fonte(s): Coluna RGB COLLETA et al.(71) ; Coluna LSM+Método elaborada pelo autor.

As amostras analisadas anteriormente, de forma individual, foram processadas com uso desse recurso. A Figura 6.10 mostra os resultados obtidos e explicita o potencial de diferenciação dessas, que passaram por tratamentos químicos distintos. Deve-se notar que o gráfico de curvas espectrais e, o respectivo histograma da amostra são os indicadores da ausência ou 
presença de assinaturas, assim como as próprias imagens mapeadas, que indicam a distribuição espacial dos espectros, pela a coloração dos pixels. Isso se deve ao fato de se executar a etapa de segmentação espectral por agrupamento, com todas as imagens multiespectrais(como se fosse uma única), obtendo-se assim, um único conjunto de assinaturas espectrais e paleta de cores. Esses são utilizados por todas as amostras, mas respeitando-se a ocorrência ou não, dos espectros mapeados, em cada amostra. Isto é, se tomarmos, por exemplo, a amostra 6.10-A pode-se notar que os sete primeiros espectros (assinalados com a cor azul) estão presentes somente nesta amostra. Já, se observarmos as amostras 6.10-C e D, é possível notar a presença de espectros comuns entre as duas amostras, como indicado pelos assinaturas espectrais, histograma e pixel na imagem de mapeamento.

Mais resultados foram obtidos pelo método, relacionado com o processo de deslignificação do bagaço de cana-de-açúcar. A dissertação de mestrado de Espírito Santo (72), em um trabalho de colaboração conjunto, fez uso do método de mapeamento espaço-espectral para a análise de fibras que passaram por pré-tratamentos físicos e químicos.
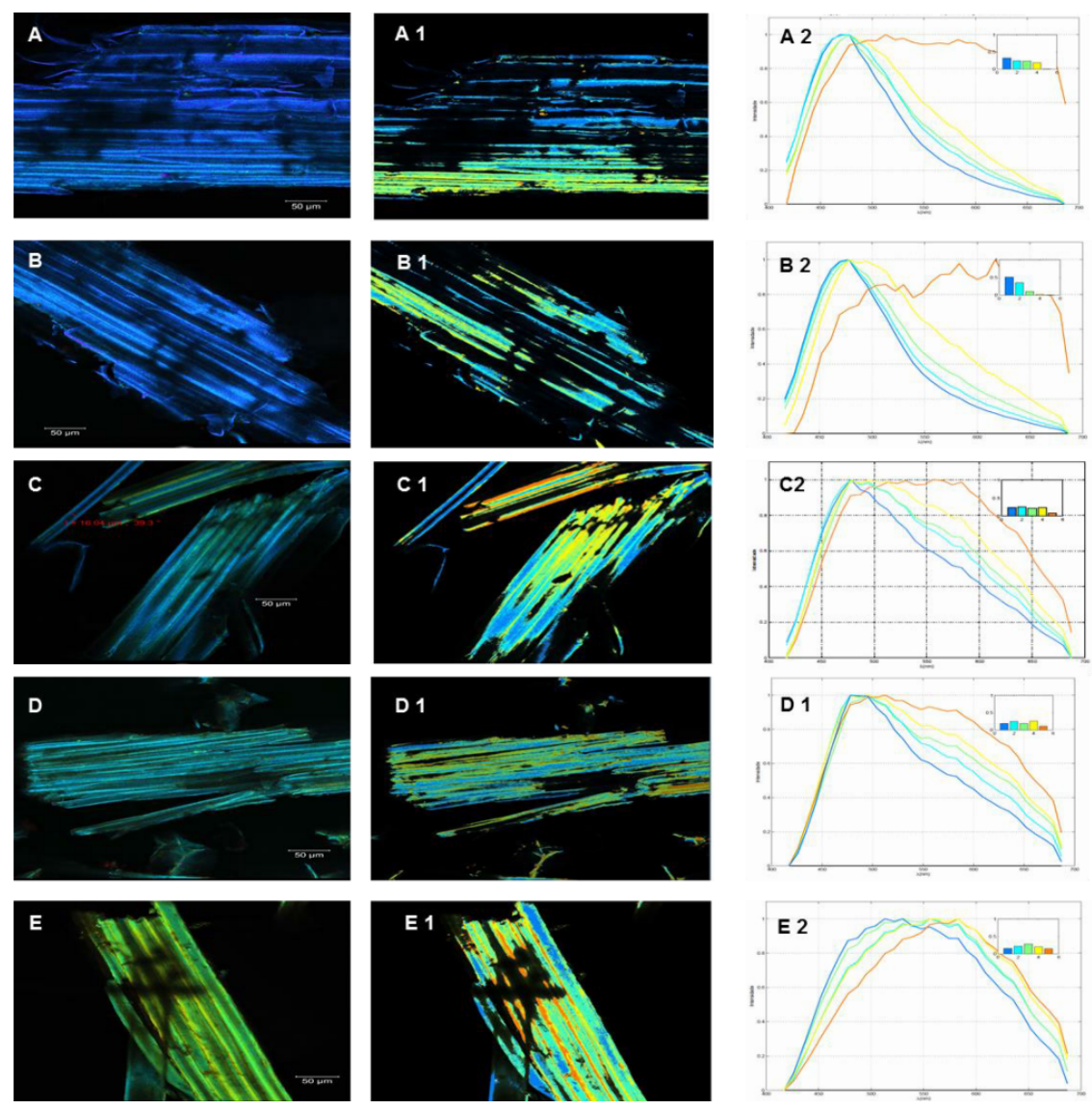

Figura 6.11 - Mapeamento de amostras de bagaço de cana-de-açúcar submetidas a tratamento hidrotérmico a $160^{\circ} \mathrm{C}$ em diferentes tempos: $(\mathrm{A})$ in natura; (B) 30min; (C) $45 \mathrm{~min} \mathrm{e;} \mathrm{(D)} 60 \mathrm{~min}$. 
A Figura 6.11 mostra o resultado de um pré-tratamento hidrotérmico em fibras de canade-açúcar. A coluna composta pelas figuras 6.11(A-D) são imagens geradas pelo microscópio e as imagens a 6.11(A1-D1) e (A2-B2) geradas pelo método de mapeamento espaço-espectral. Como pode-se verificar, com a aplicação do método torna-se nítida as regiões que sofreram alterações em sua assinatura espectral.
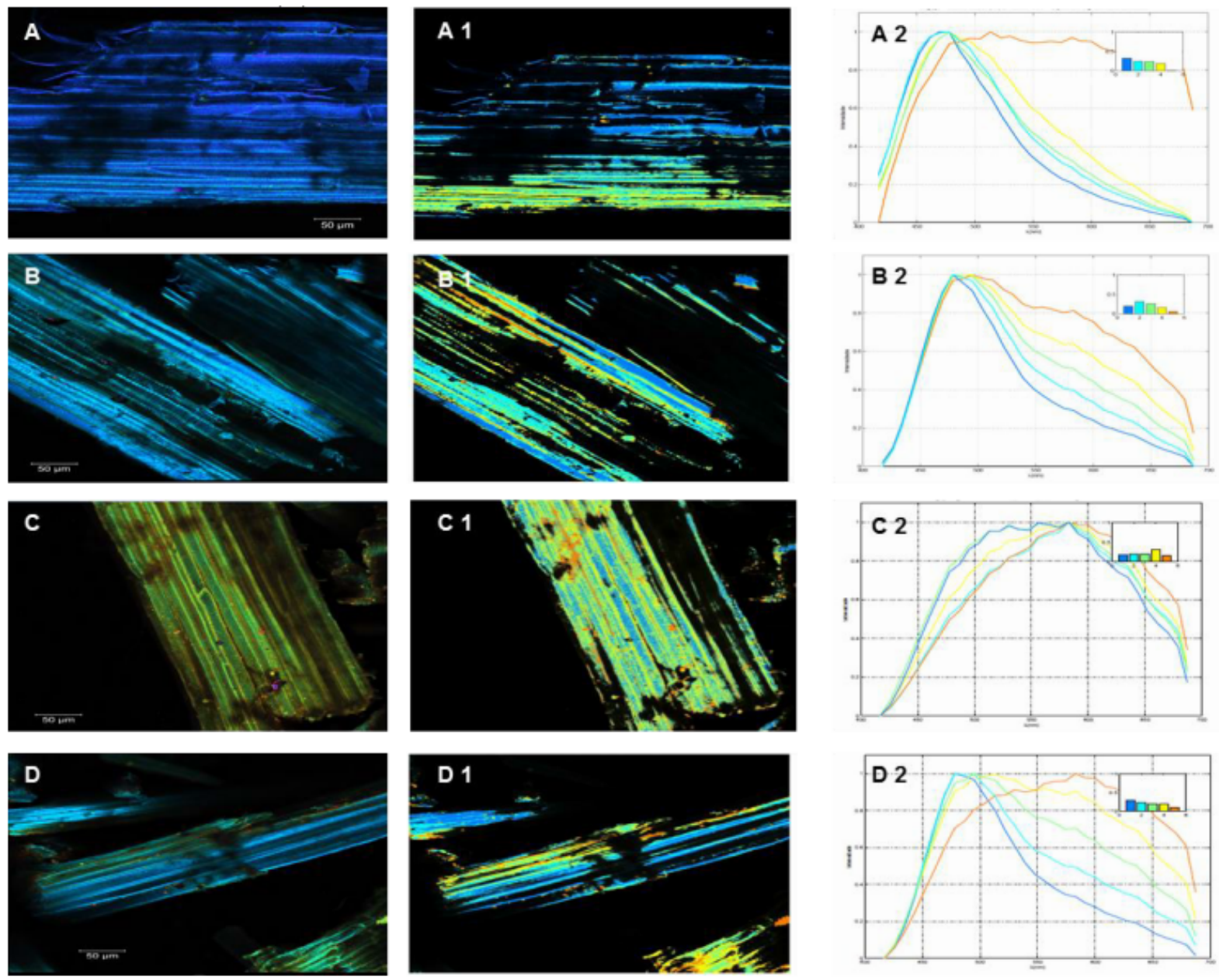

Figura 6.12 - Imagens de (A) fibras in natura;tratadas por organossolvente: pelos tempos de : (B) 50min; (C) 100min e; (D) 150min.

Fonte(s): ESPÍRITO SANTO (72)

A Figura 6.12 mostra o resultado de um pré-tratamento em fibras submetidas a organossolvente. Da mesma forma que a figura anterior, as imagens na Figura 6.12(A-D) foram geradas pelo microscópio e as imagens 6.12(A1-D1) e (A2-B2) geradas pelo método de mapeamento espaço-espectral. Novamente as regiões com assinatura espectrais diferenciadas podem ser identificadas e comparadas com os demais pré-tratamentos, como os da Figura 6.11 e6.12. 

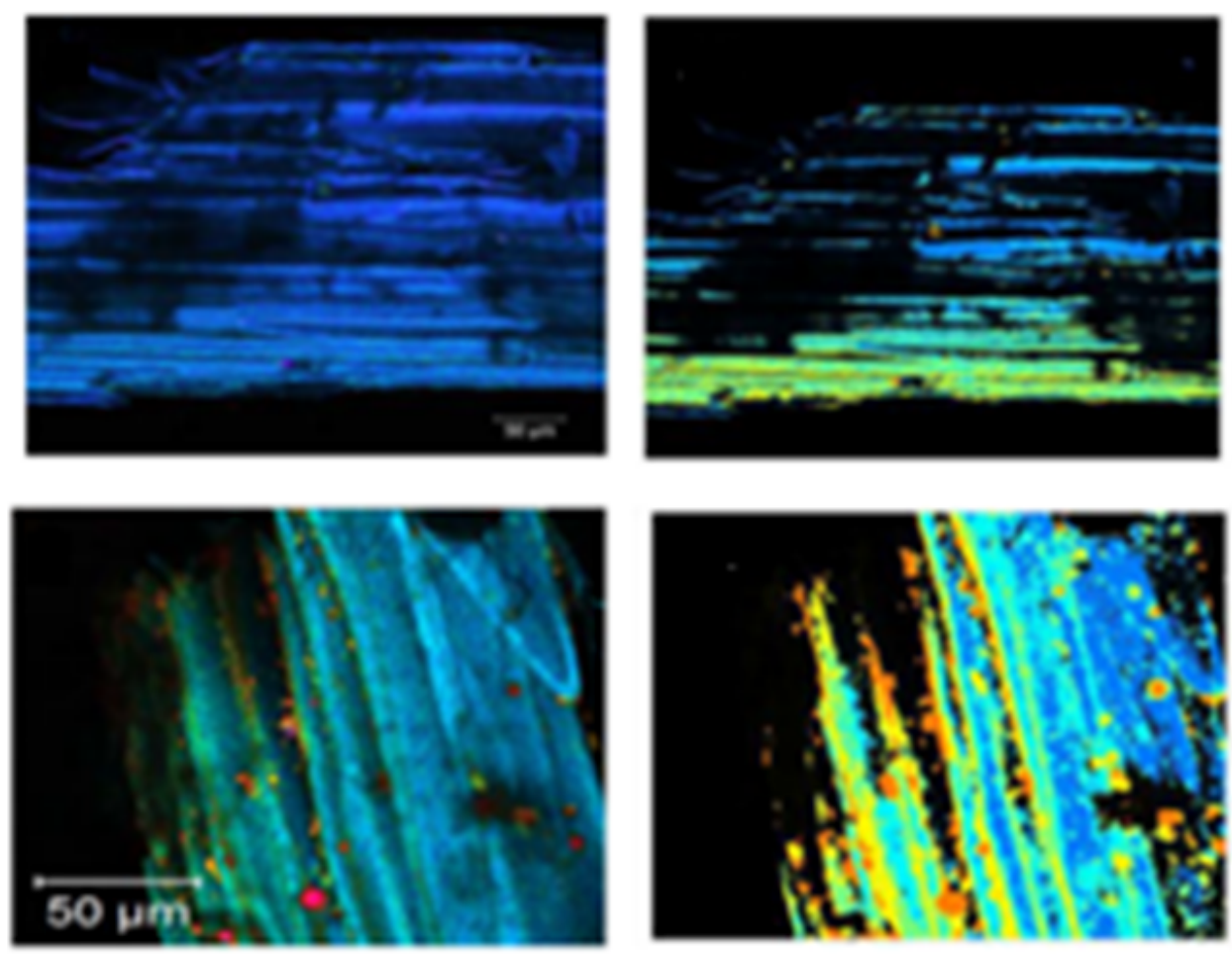

Figura 6.13 - Detalhes de: (A) Fibras in natura;tratadas por organossolvente; (B) Fibra que passou por tratamento combinado, hidrotérmico e organossolve, iniciado com hidrotérmico por 30 min e seguido por organossolve por $150 \mathrm{~min}$.

Fonte(s): ESPÍRITO SANTO(72)

A Figura 6.13 mostra o detalhe de amostras de feixes de células vegetais, de bagaço de cana, que passaram por tratamento químico 6.13-A e tratamento físico e químico combinados 6.13-B. Neste último, com a aplicação do método, fica evidente a formação de pequenos depósitos de lignina entre os feixes de células vegetais. 


\subsection{Resultados da análise da plasticidade foliar do Jara- canda caroba}
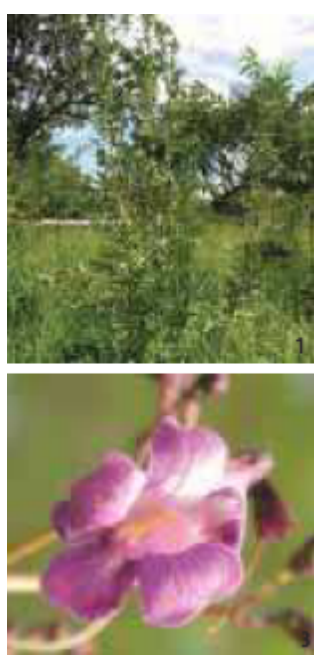
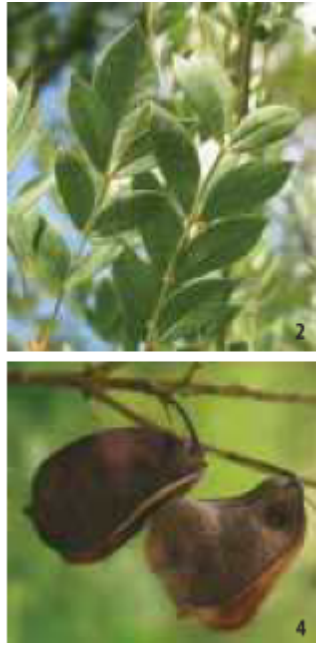

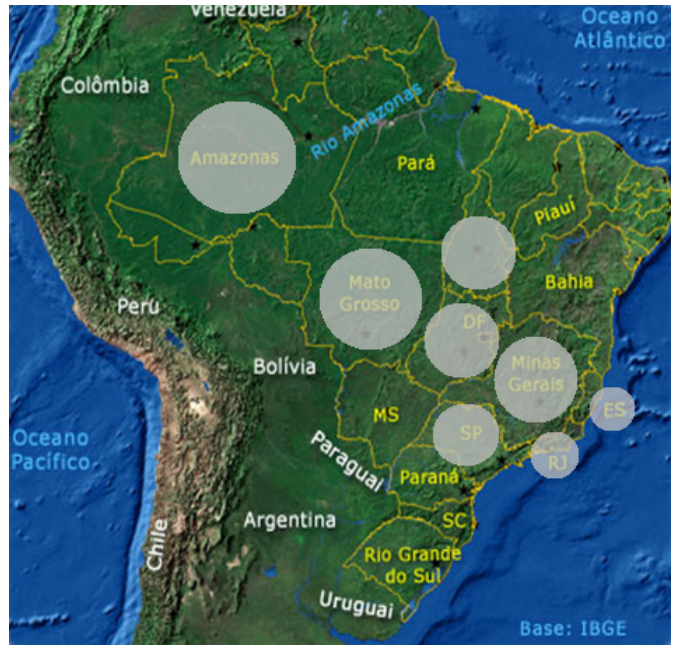

Figura 6.14 - Esq. - Jacaranda caroba, planta (1), folhas (2), flores (3) e frutos (4); (Dir.) ocorrência no pais.

Fonte(s): esq. CESAR et al. (90); dir. GUIA (89).

Este estudo foi realizado em trabalho de cooperação com a equipe de pesquisadoras da Profa. Rosana Kolb, da UNESP de Assis. O foco do grupo da Profa. Rosana é estudar o uso da espécie Jacaranda caroba, como um bio-sensor de poluentes. Uma vantagem da espécie escolhida é o fato desta ser encontrada em diversos estados do Brasil, tais como: Amazonas, Tocantins, Goiás, Mato Grosso, Minas Gerais, São Paulo, Rio de Janeiro e Espírito Santo; além, de ser uma planta utilizada na arborização de cidades.

Para que o estudo da plasticidade foliar do Jacaranda caroba fosse realizado por meio de imagens de microscopia confocal à laser, e com a aplicação do método de mapeamento espaço-espectral, a Profa. Rosana e equipe forneceram lâminas de cortes foliares, de seis grupos de indivíduos, que foram semeados e cultivados em ambiente controlado. Desses, cinco grupos foram expostos de forma sistemática, por borrifação, à fluoreto de potássio(KF) sendo atribuída para cada grupo uma das respectivas concentrações de KF: $5 \mathrm{mg} / \mathrm{L}, 15 \mathrm{mg} / \mathrm{L}$, $30 \mathrm{mg} / \mathrm{L}, 60 \mathrm{mg} / \mathrm{L}$ e $1162 \mathrm{mg} / \mathrm{L}$, por um período de 60 dias. O sexto grupo de indivíduos, foi tomado como grupo de controle, e não teve contato com tal substância.

Finalizado o período de exposição ao KF, as folhas foram coletadas, e lâminas de cortes foliares de cada grupo, foram preparadas em triplicata. Também foi fornecido um conjunto de imagens de cortes foliares, por microscopia ótica - uma imagem de cada um dos grupos que foram expostos à substância, e uma imagem de um indivíduo do grupo de controle também 
foi fornecida ( ver Figura 6.15). As lâminas foram capturadas no microscópio confocal à laser Zeiss LSM 780, do Instituto de Física de São Carlos - USP, e as imagens multiespectrais resultantes, dessa captura, foram processadas pelo método de mapeamento espaço-espectral. Os resultados podem ser vistos na Figura 6.16.
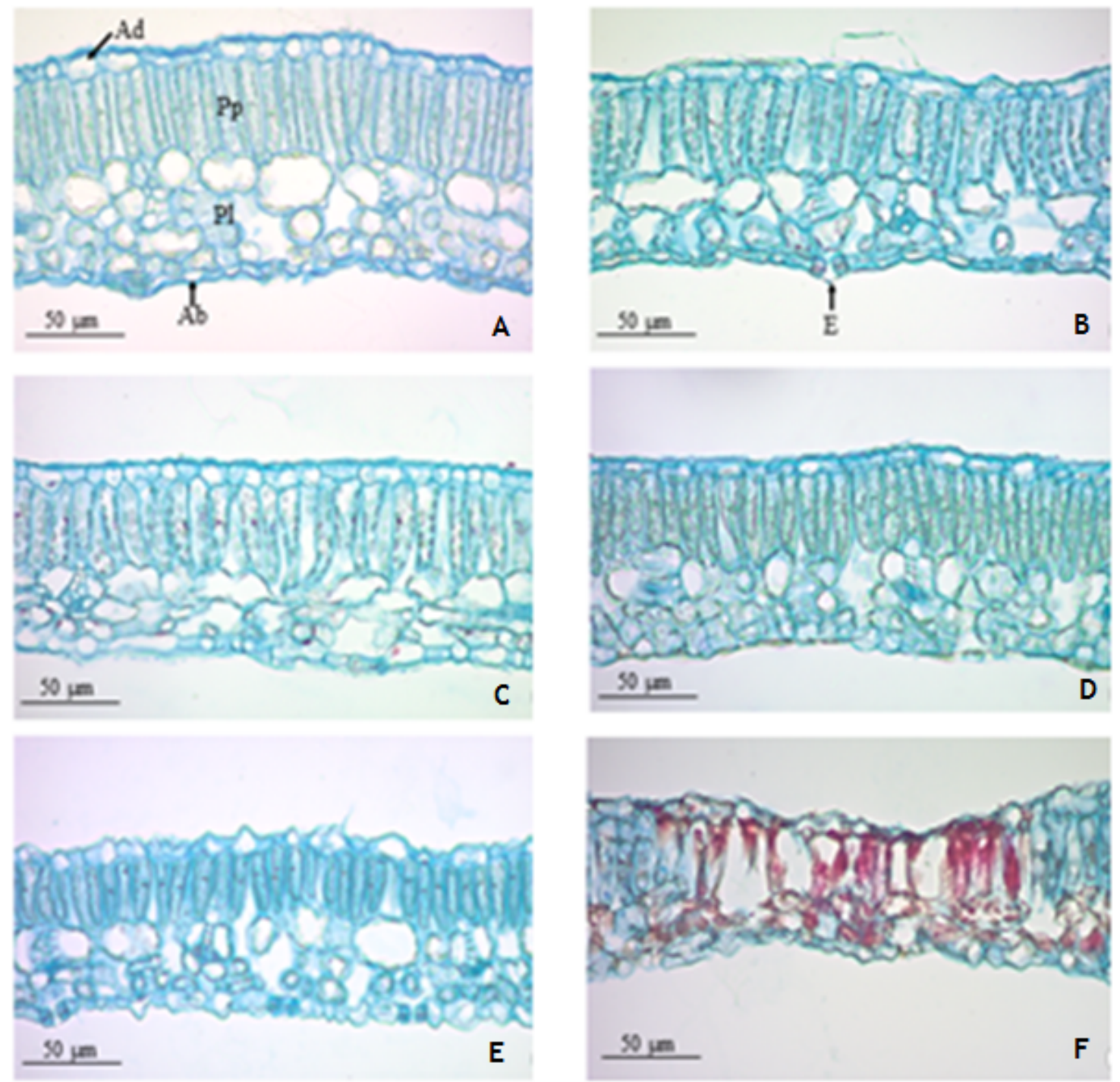

Figura 6.15 - Amostras de cortes do Jacaranda caroba obtidas por coloração para microscopia ótica. (A) Controle; (B) $5 \mathrm{mg} / \mathrm{L}$; (C) $15 \mathrm{mg} / \mathrm{L}$; (D) $30 \mathrm{mg} / \mathrm{L}$; (E) $60 \mathrm{mg} / \mathrm{L} \mathrm{e}$; (F) $1162 \mathrm{mg} / \mathrm{L}$.

Fonte(s): Rosalna Kolb ${ }^{\S}$

Analisando as imagens obtidas por meio de um microscópio ótico, as pesquisadoras informaram que somente é possível notar alterações na estrutura do corte foliar, a partir das amostras de concentrações de $30 \mathrm{mg} / \mathrm{L}, 60 \mathrm{mg} / \mathrm{L}$ e $1162 \mathrm{mg} / \mathrm{L}$, na epiderme abaxial. Entretanto 
se observar as folhas a olho nu, só é possível notar alterações nas amostras de concentração de $1162 \mathrm{mg} / \mathrm{L}$. A partir dessa informação, decidiu-se então aplicar o método de mapeamento espaço-espectral, cujos resultados são mostrados na Figura 6.16.
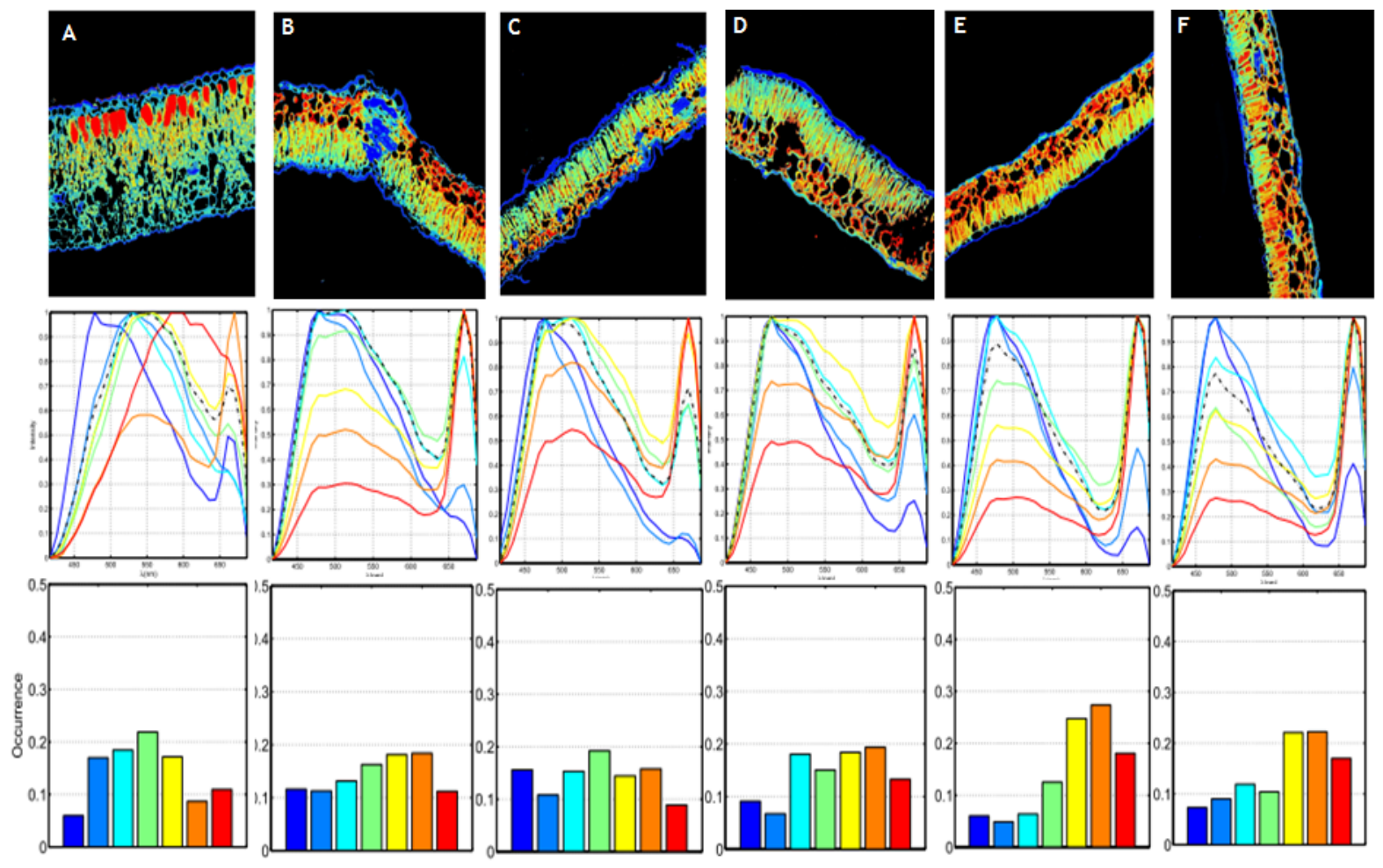

Figura 6.16 - Imagens multiespectrais de amostras Jacarandá caroba após aplicação do método.(A) Controle; (B) $5 \mathrm{mg} / \mathrm{L}$; (C) $15 \mathrm{mg} / \mathrm{L}$; (D) $30 \mathrm{mg} / \mathrm{L}$; (E) $60 \mathrm{mg} / \mathrm{L} \mathrm{e}$; (F) $1162 \mathrm{mg} / \mathrm{L}$.

Fonte(s): Elaborada pelo autor.

Com base nas informações obtidas pelas imagens de mapeamento e gráficos de curvas e respectivos histogramas (Figura 6.16) é possível notar, que há na amostra controle (6.16A), diferenças sensíveis em sua epiderme foliar, quando comparada com as demais amostras mapeadas (ausência de um composto vermelho sobre a epiderme). Essa diferença também é constatada nas assinaturas espectrais das demais amostras mapeadas - uma hipótese é que essa substância seja uma camada de antocianina, que acredita-se proteger os cloroplastos da ação danosa da radiação ultravioleta. Seu desaparecimento poderia estar relacionado com a ação do fluoreto de potássio. Essa diferença já se torna evidente, logo na primeira classe de amostra de concentração de $5 m g / L$ (6.16-B).

Outro ponto a ser observado, é a tendência de deslocamento do centro de massa do histograma para à direita do espectro. Isto parece estar relacionado com o aumento de cloroplastos, o que parece fazer bastante sentido, pois esse emitem luz na faixo vermelha do 
espectro. Embora haja algumas variações nas assinaturas espectrais é coerente supor que a predominância dessas assinaturas parecem ser o resultado de uma composição de assinaturas, principalmente de lignina e clorofila.

Uma breve análise nas amostras submetidas à concentração de $15 \mathrm{mg} / \mathrm{L}$ (Figura 6.16-C) e $30 \mathrm{mg} / L$ (Figura 6.16-D) indicam a permanência de assinaturas semelhantes as na Figura 6.16-B e inclusive indicando que há uma aumento na frequência das assinaturas, que estão mais próximas ao comprimento de onda de $700 \mathrm{~nm}$, como fica bastante evidente no histograma da Figura 6.16-E em que a amostra foi tratada com $60 \mathrm{mg} / \mathrm{L}$. Entretanto, ao mapearmos uma amostra a que foi submetida a uma concentração de $1162 \mathrm{mg} / L$ (Figura 6.16-F) esta parece tentar estabelecer um conjunto de assinaturas e ocorrências sementes ao da amostra 6.16-B.

Em função das informações obtidas pelo método de mapeamento espaço-espectral, muitas outras considerações foram levantadas e o grupo ainda discute as possíveis causas das mudanças químicas e estruturais ocorridas, requerendo novos experimentos. Entretanto, pelos resultados obtidos deste experimento, foi possível comprovar sua sensibilidade com relação às variações plásticas de uma folha.

Nas páginas seguintes, foram impressas ampliações da amostras mapeadas da Figura 6.16 com seus respectivos gráficos de curvas espectrais e histograma. Também é impresso a imagem gerada pelo software proprietário do microscópio, para efeito de comparação. 

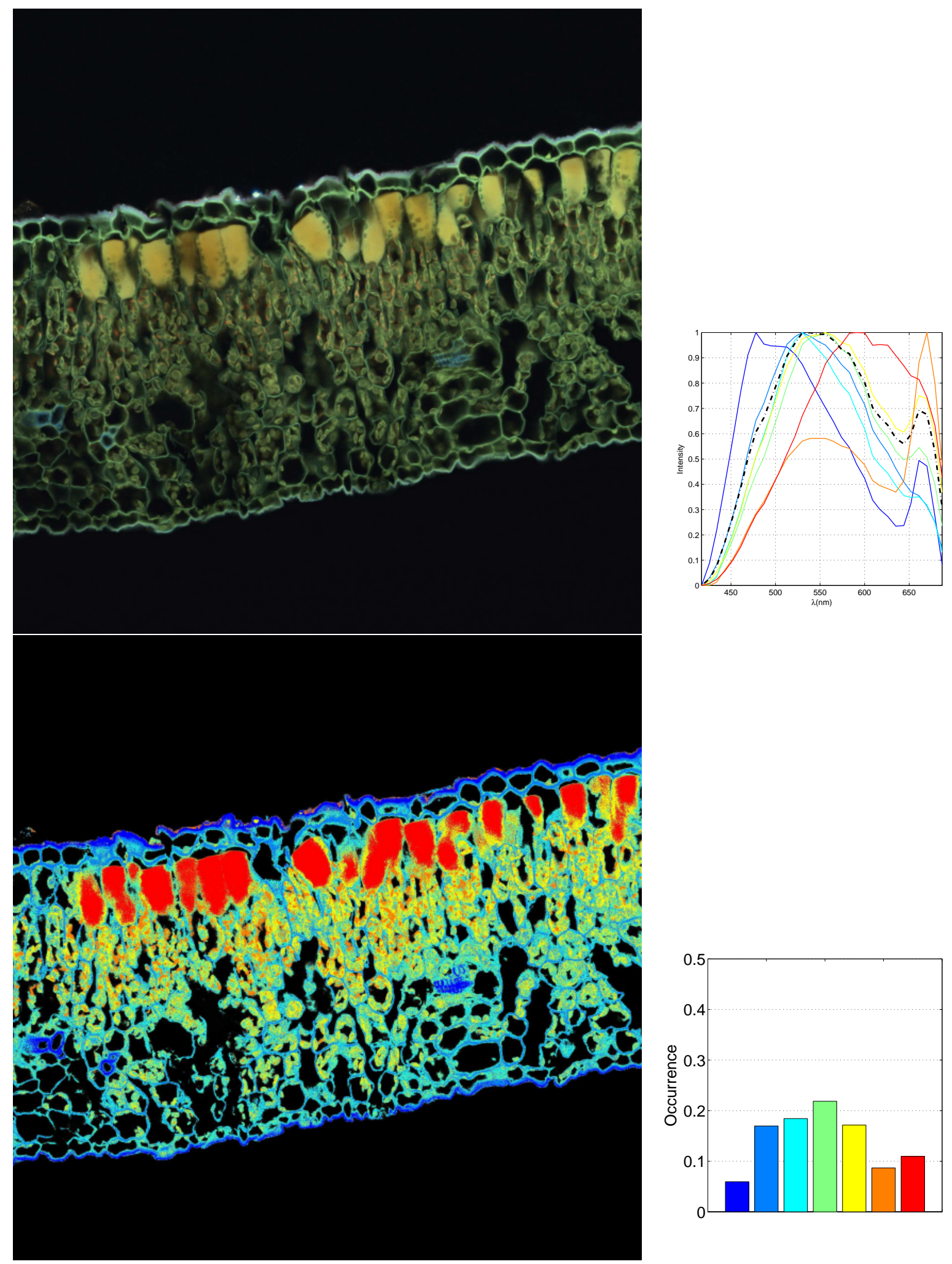

Figura 6.17-Folha controle.

Fonte(s): Lâmina de Rosana Kolb. Imagens e gráficos do próprio autor. 

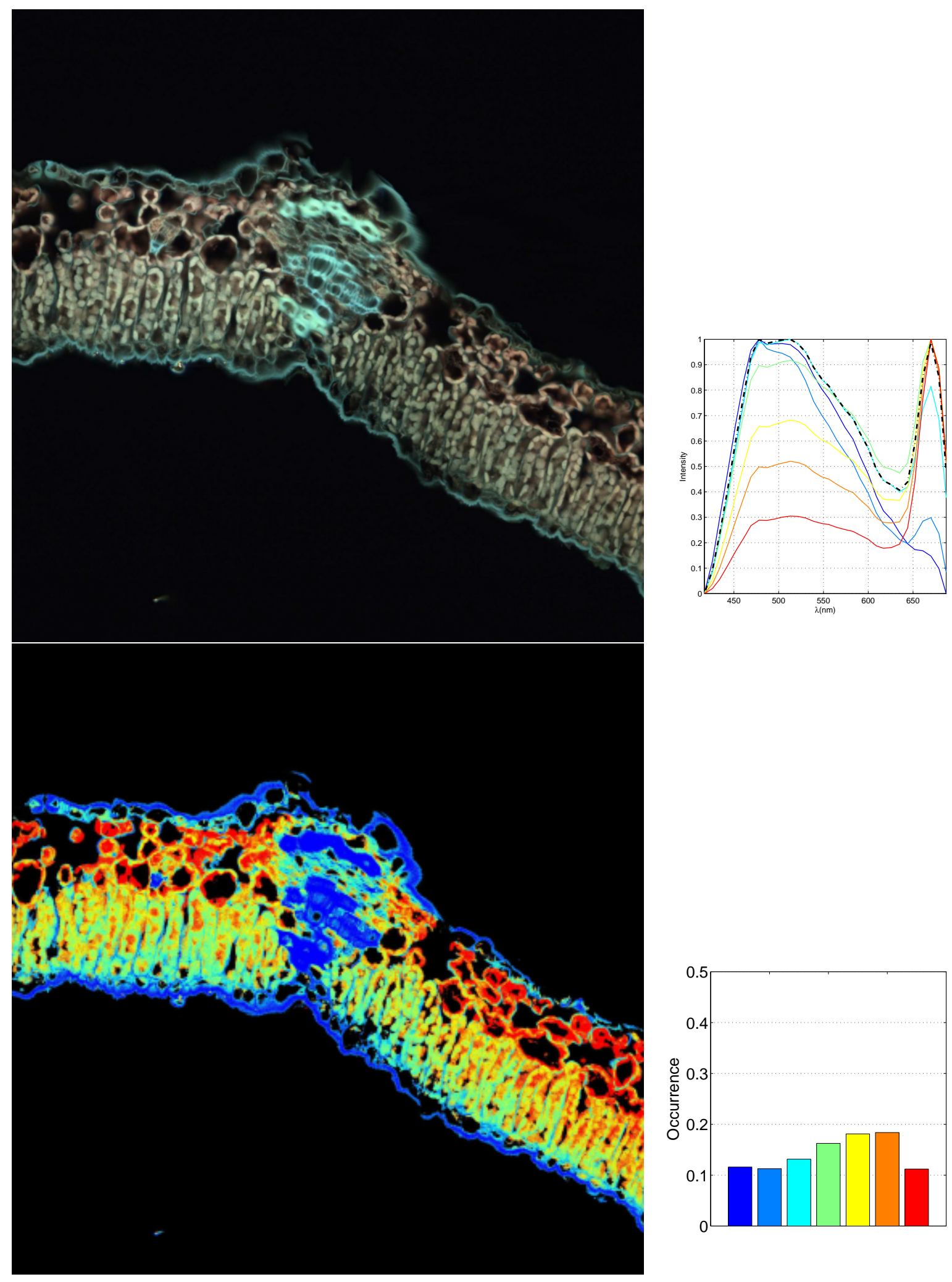

Figura 6.18-Concentração $5 \mathrm{mg} / \mathrm{l}$.

Fonte(s): Lâmina de Rosana Kolb. Imagens e gráficos do próprio autor. 

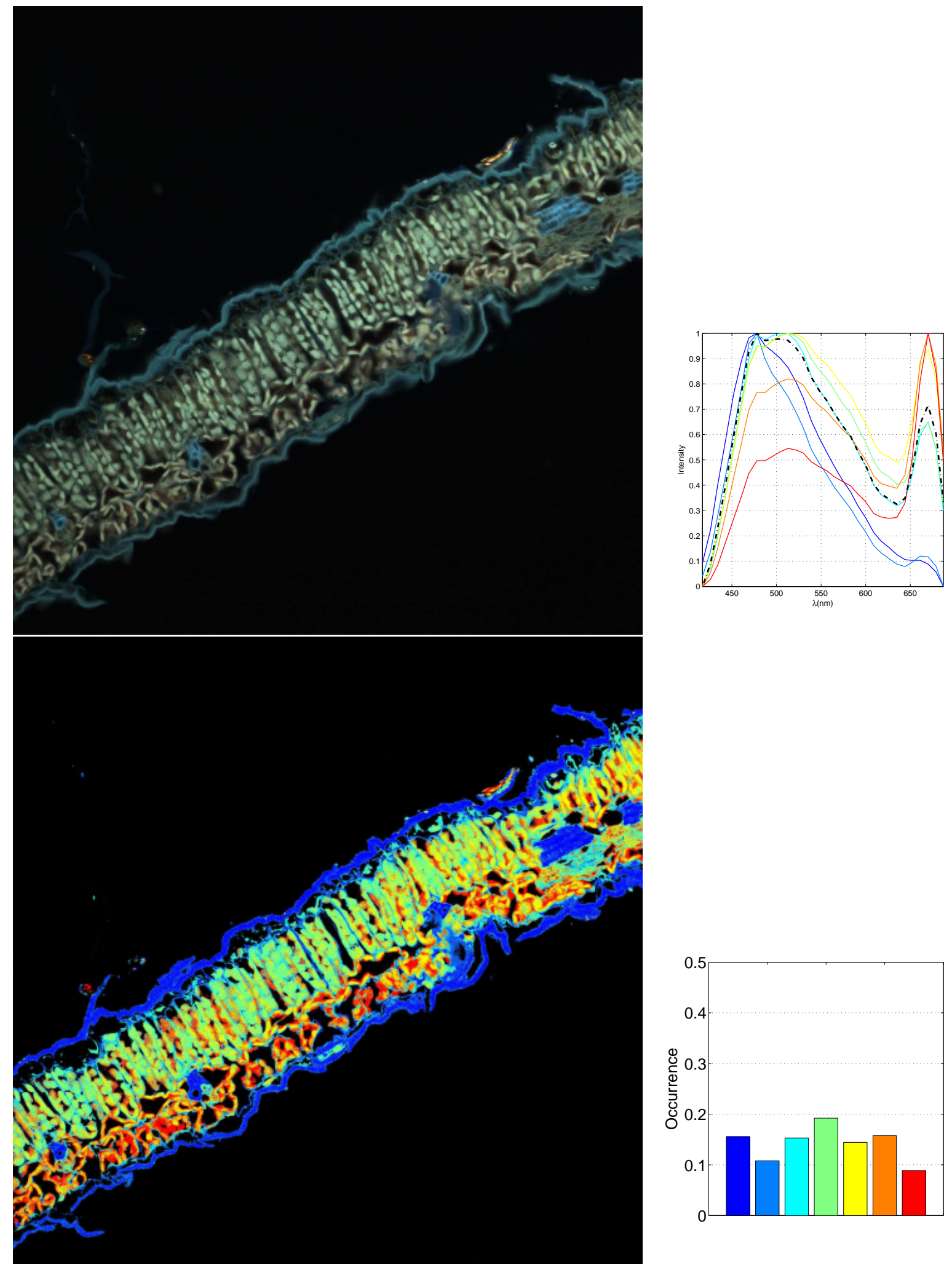

Figura 6.19-Concentração $15 \mathrm{mg} / \mathrm{l}$.

Fonte(s): Lâmina de Rosana Kolb. Imagens e gráficos do próprio autor.

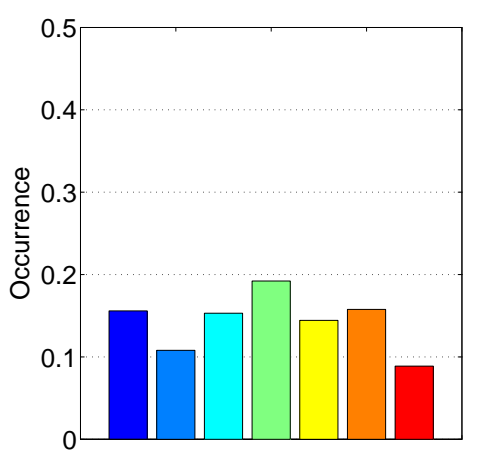



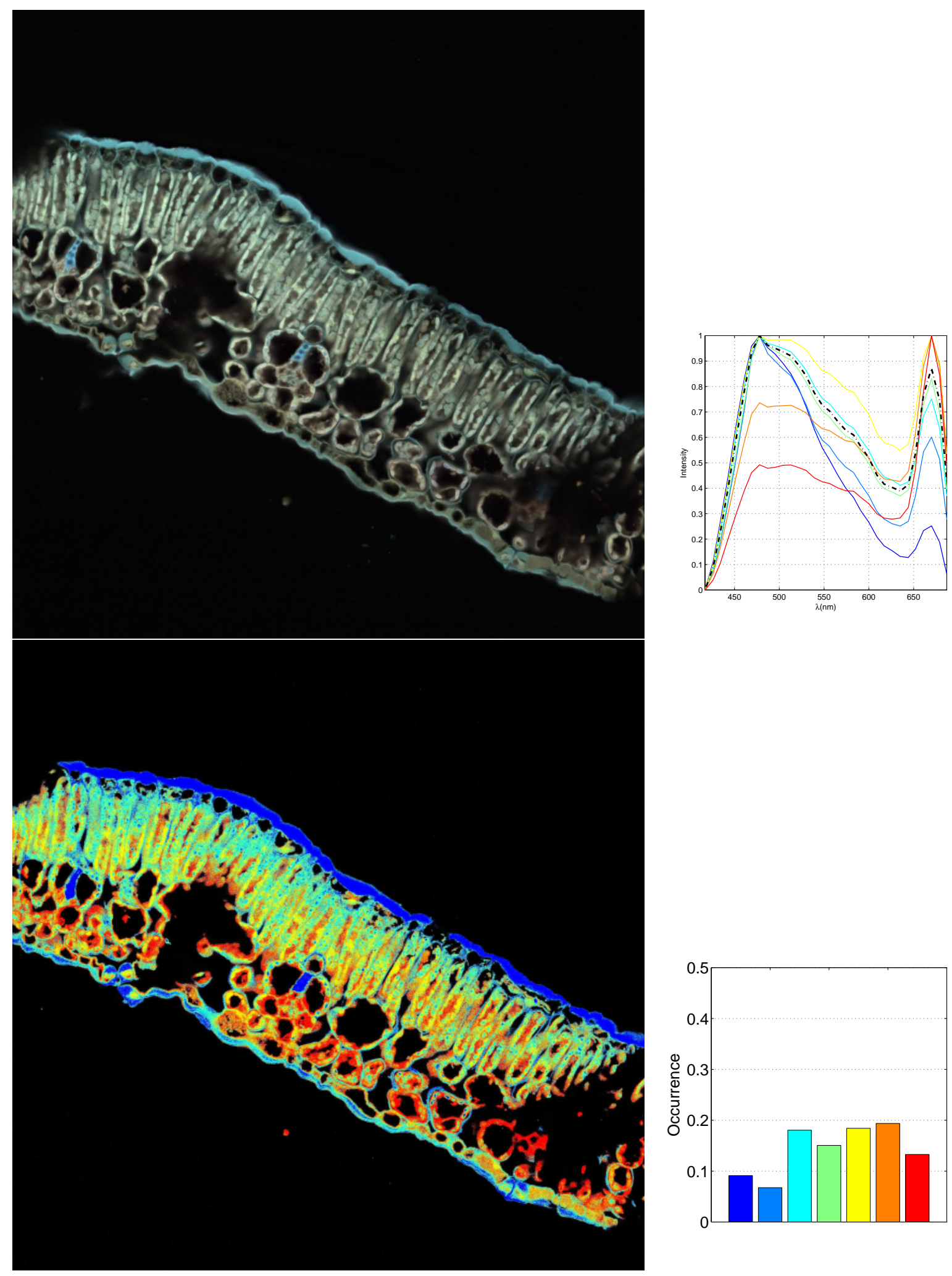

Figura 6.20-Concentração $30 \mathrm{mg} / \mathrm{l}$.

Fonte(s): Lâmina de Rosana Kolb. Imagens e gráficos do próprio autor. 

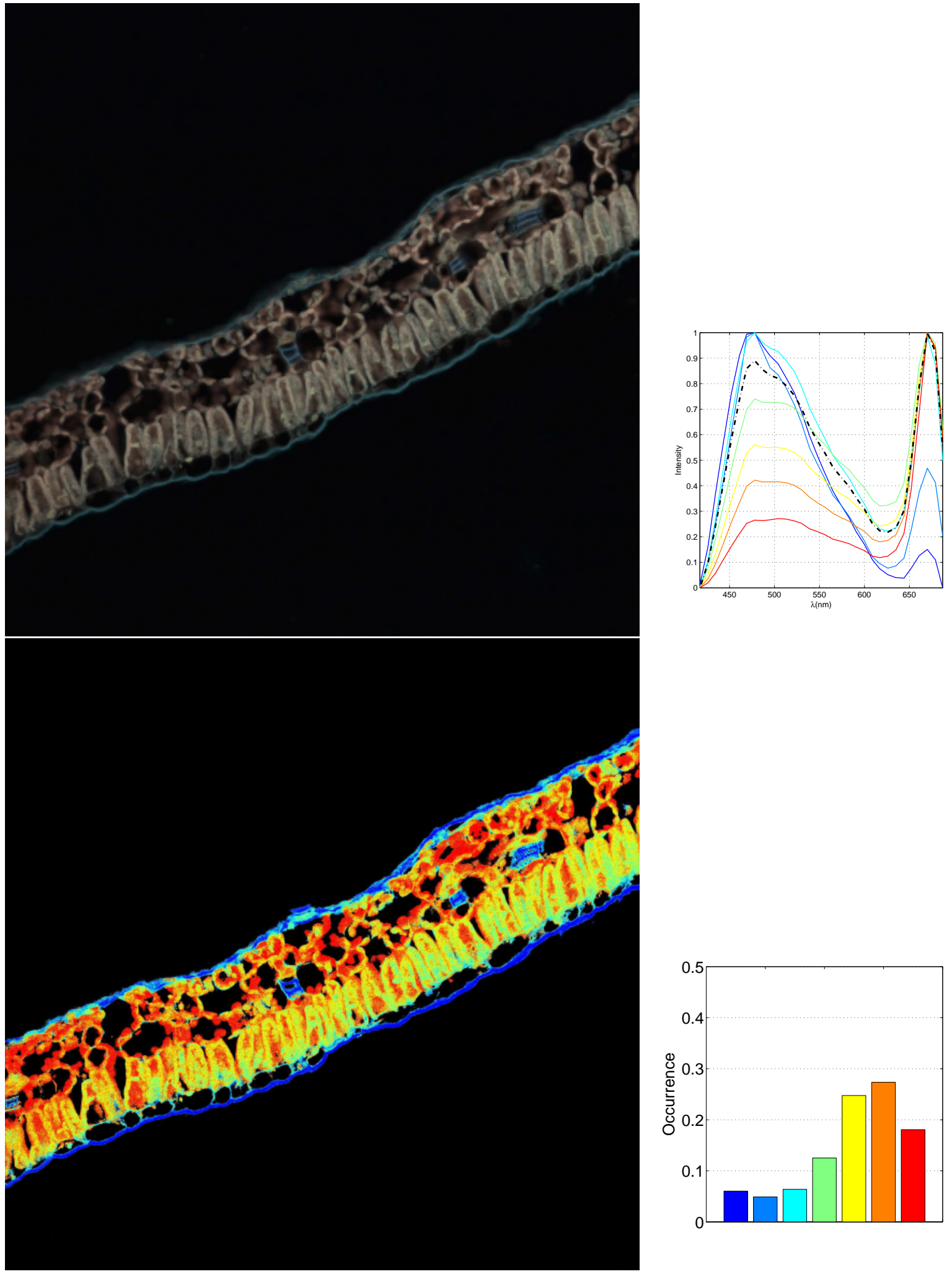

Figura 6.21-Concentração $60 \mathrm{mg} / \mathrm{l}$.

Fonte(s): Lâmina de Rosana Kolb. Imagens e gráficos do próprio autor.

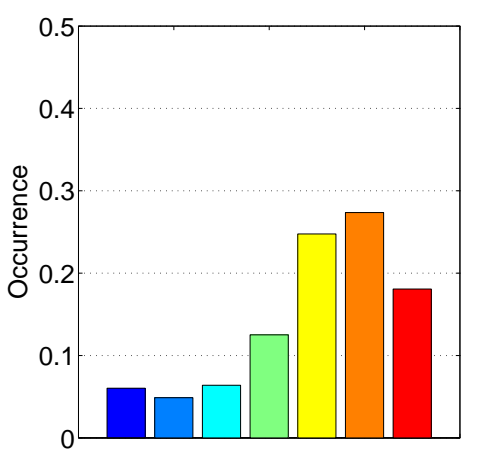



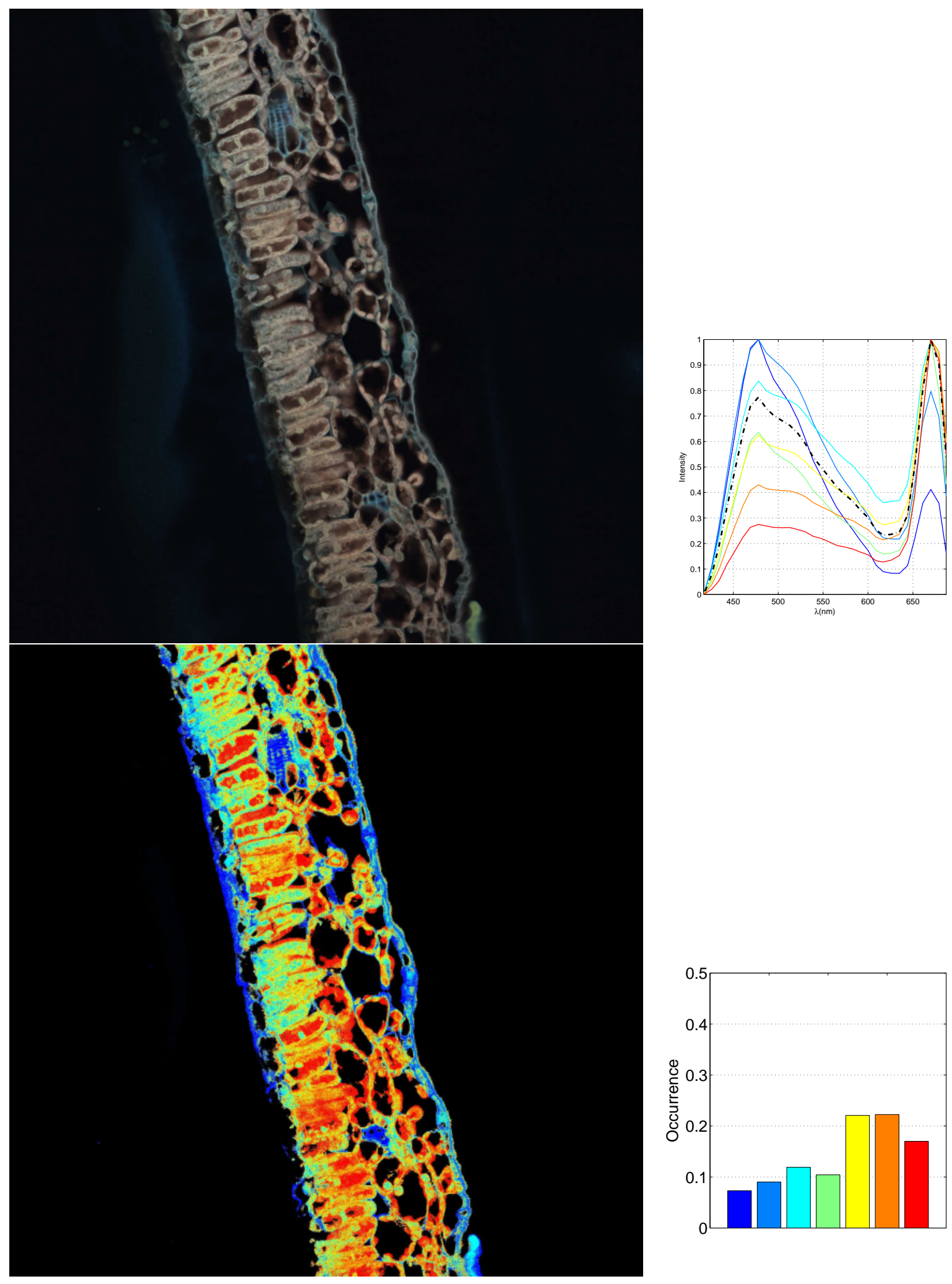

Figura 6.22-Concentração $1162 \mathrm{mg} / \mathrm{l}$.

Fonte(s): Lâmina de Rosana Kolb. Imagens e gráficos do próprio autor. 


\subsection{Resultados na identificação pela assinatura espectral de plantas do Cerrado}

Pela capacidade de levantamento do conjunto espectral completo, contido em toda a extensão de uma imagem multiespectral, o método desenvolvido foi testado, em uma coleção de lâminas de tecidos foliares com o objetivo de classificar 337 cortes foliares, de 30 espécies de plantas do Cerrado. Assim, foram coletadas todas as 337 lâminas e extraído o conjunto de assinaturas espectrais, de cada das amostras. Foram testado dois classificadores supervisionados bem conhecidos e referenciados, o Knn e o NaiveBayes. Com esses classificadores atingiu-se uma classificação global máxima de $53 \%$ para $\mathrm{K}=5$ e utilizando um agrupamento de 5 espectros. Cabe esclarecer entretanto, que a base de lâminas utilizada não possui uma uniformidade quanto à região de origem. Isto é, de uma mesma espécie pode haver amostras de indivíduos que vieram de regiões úmidas e outros indivíduos da mesma espécie podem ter vindo de uma região seca, ocasionando a influência da questão da plasticidade foliar. O que justifica a taxa de classificação atingida, considerando que o método é sensível à plasticidade foliar.

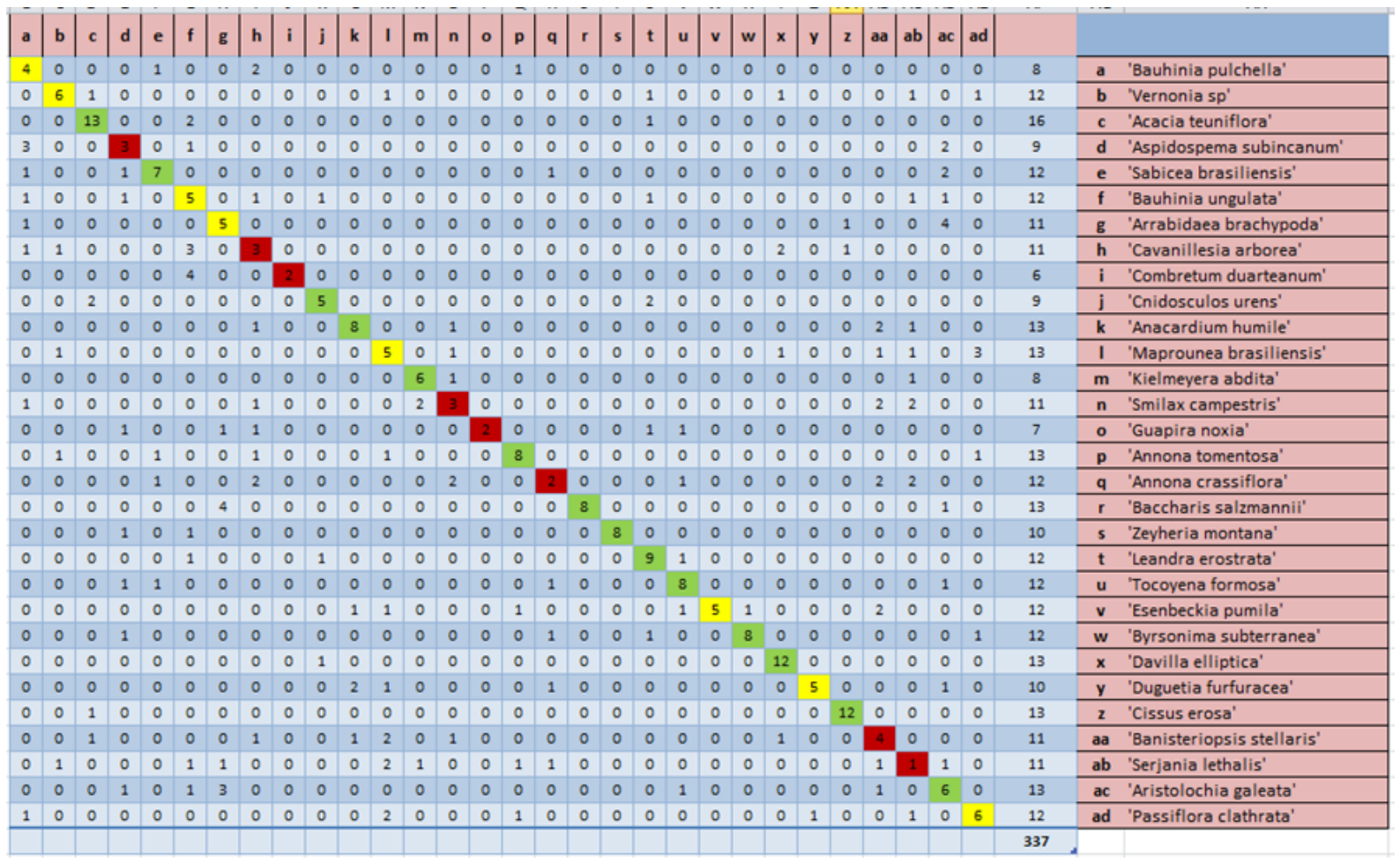

Figura 6.23-Matriz confusão do processo de classificação das assinaturas espectrais.

Fonte(s): Elaborada pelo próprio autor. 
A matriz confusão a seguir, mostra as classes classificadas. As células das classes que estão assinaladas em verde tiveram um acerto de classificação da classe, próximo a $90 \%$, as assinaladas em amarelo próximas a $50 \%$ e as em vermelho, abaixo de $50 \%$. Nas páginas seguintes são mostradas imagens de mapeamento espectral e respectivos gráficos espectrais e histograma de cada espécie juntamente com a imagem RGB gerada pelo software proprietário do microscópio. 

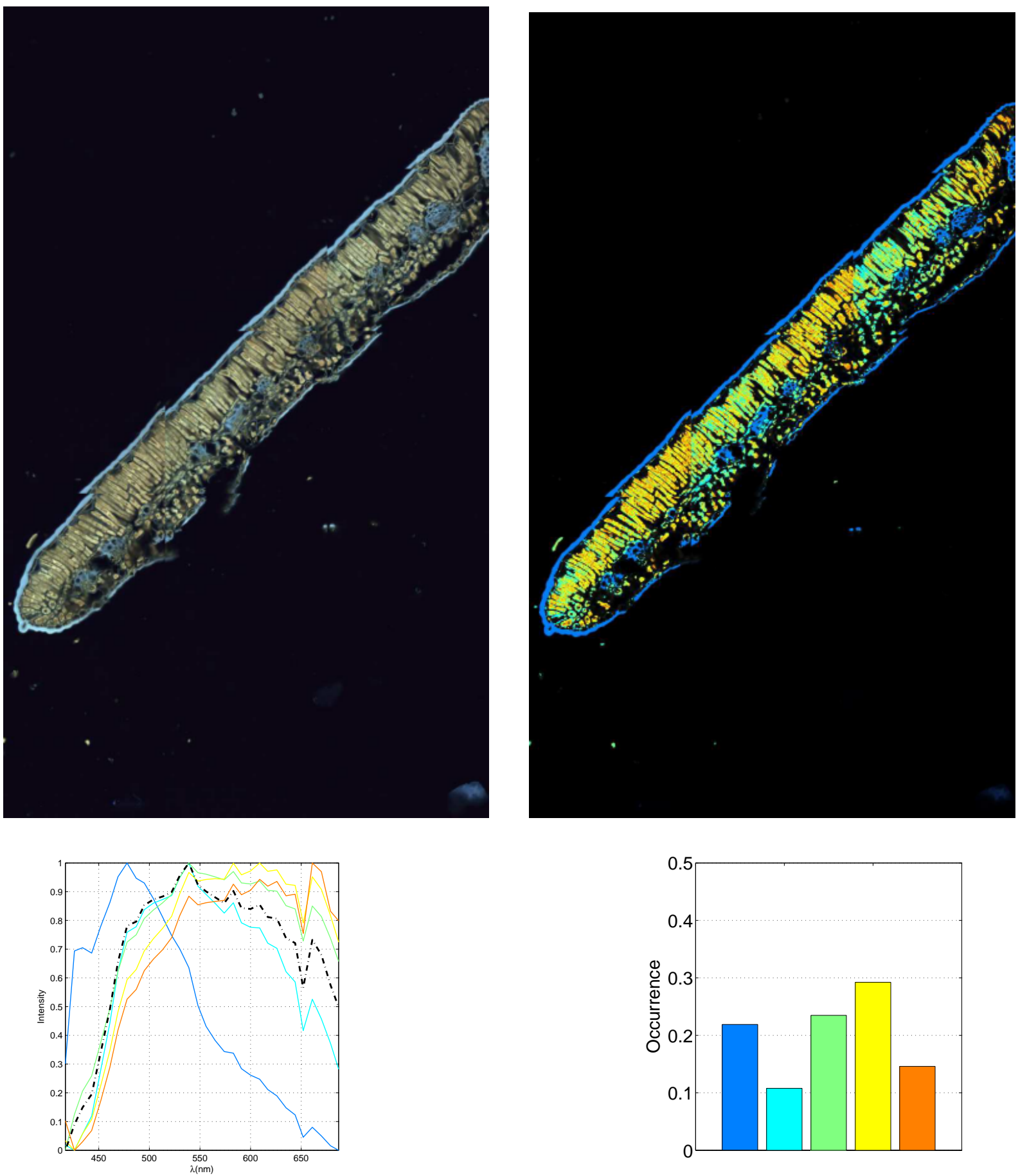

Figura 6.24-Acacia teuniflora.

Fonte(s): Lâmina de Rosana Kolb. Imagens e gráficos do próprio autor. 

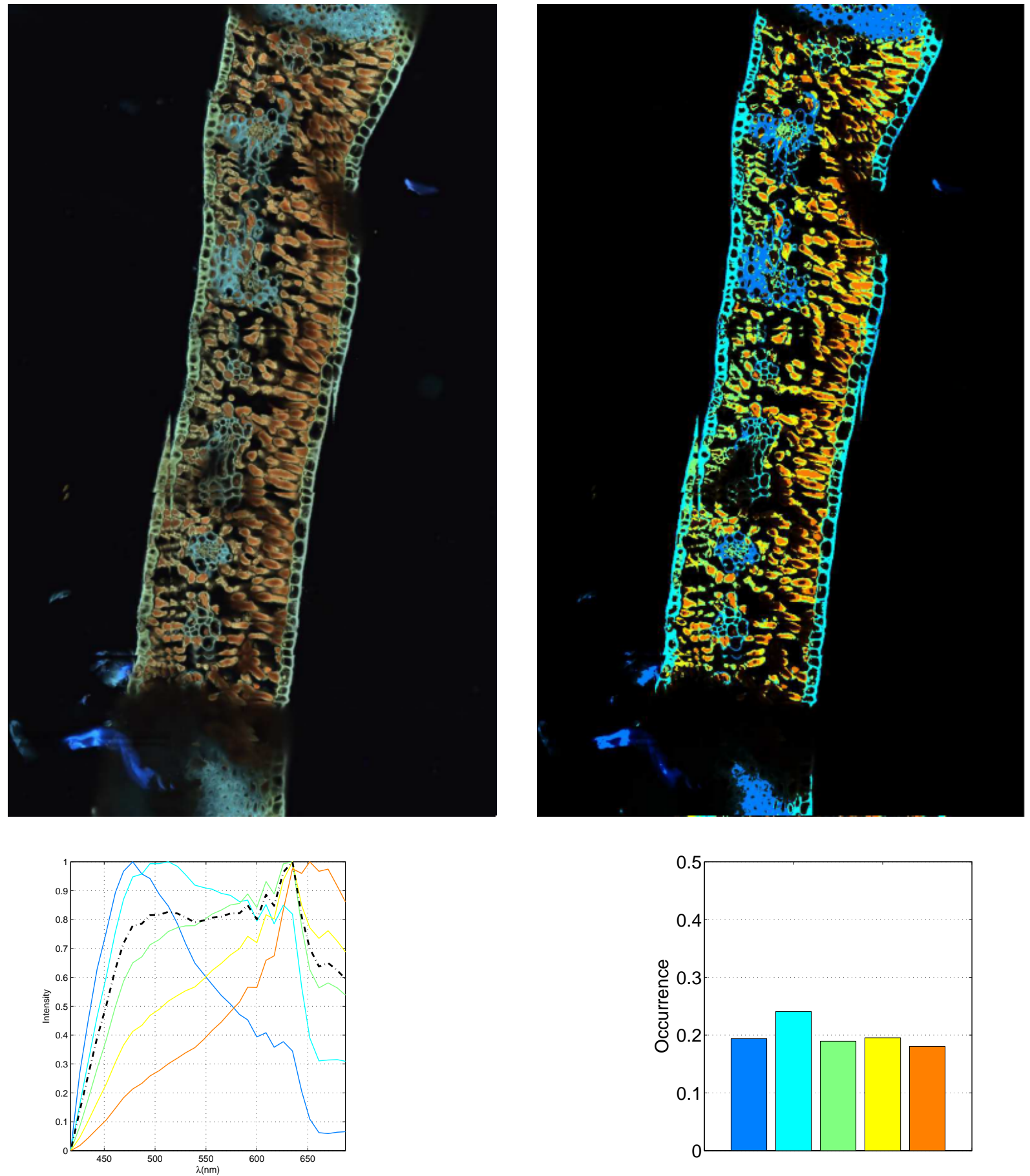

Figura 6.25-Anacardium humile.

Fonte(s): Lâmina de Rosana Kolb. Imagens e gráficos do próprio autor. 

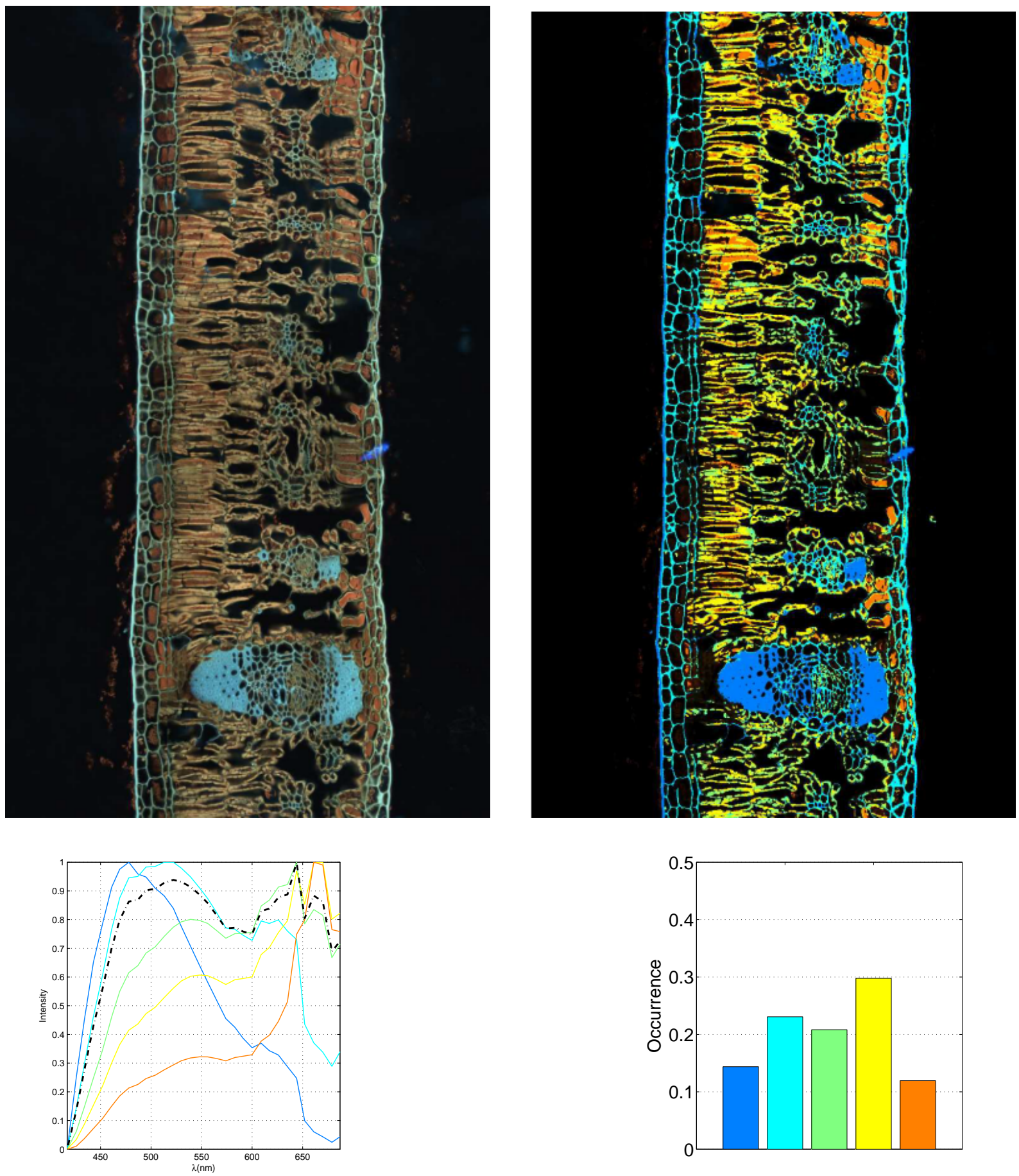

Figura 6.26-Annona crassiflora.

Fonte(s): Lâmina de Rosana Kolb. Imagens e gráficos do próprio autor. 

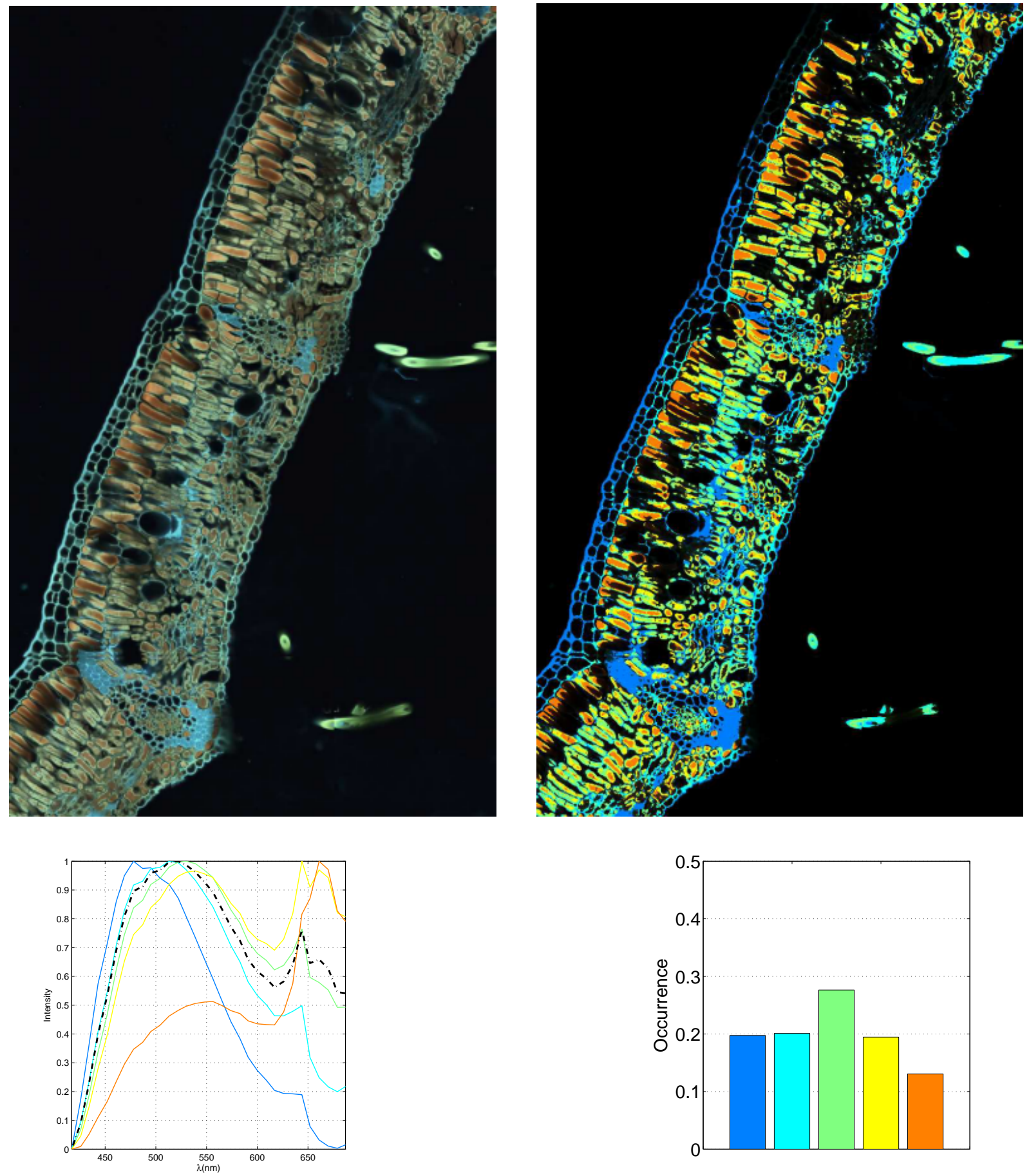

Figura 6.27-Annona tomentosa.

Fonte(s): Lâmina de Rosana Kolb. Imagens e gráficos do próprio autor. 

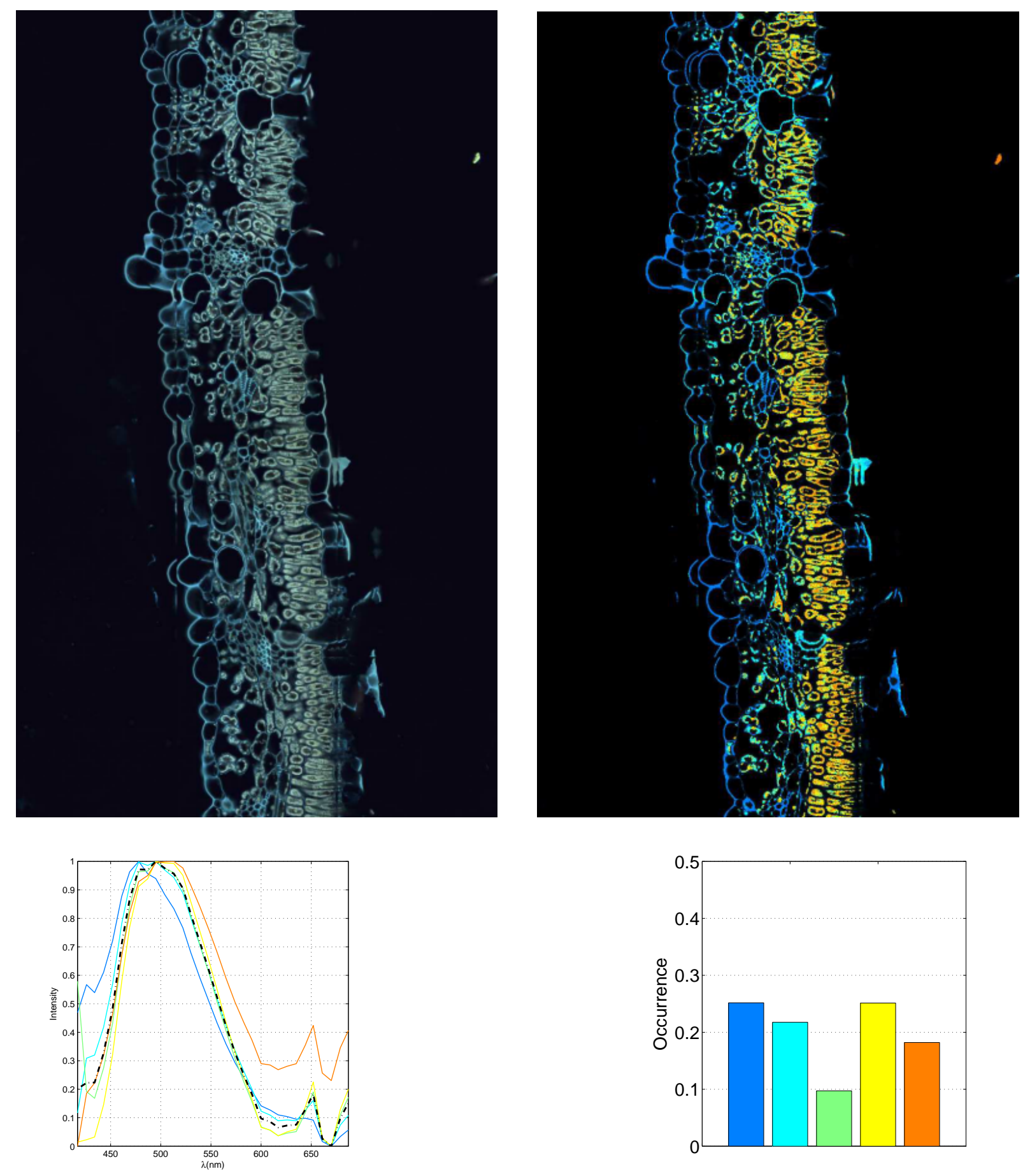

Figura 6.28-Aristolochia galeata.

Fonte(s): Lâmina de Rosana Kolb. Imagens e gráficos do próprio autor. 

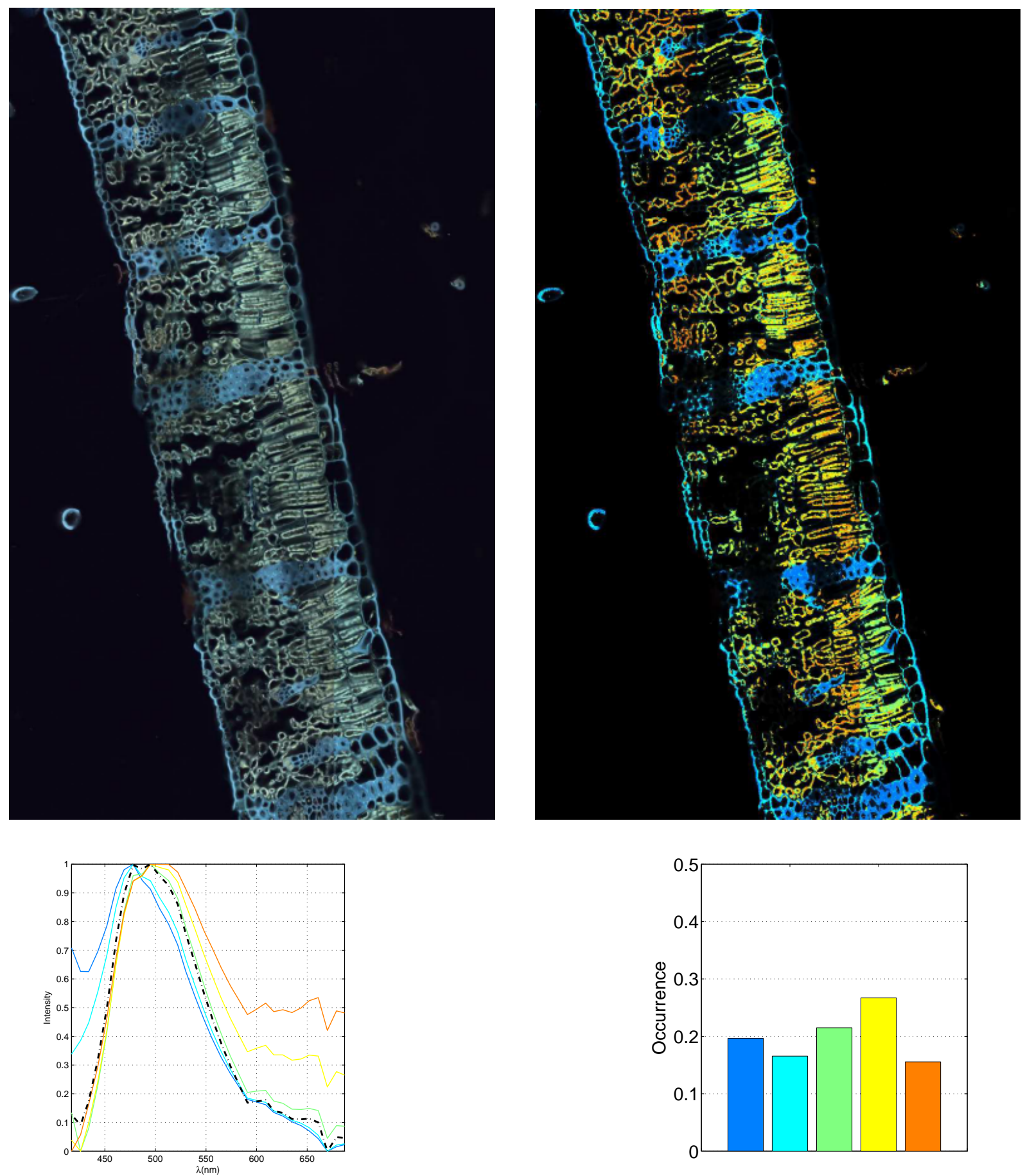

Figura 6.29-Arrabidaea brachypoda.

Fonte(s): Lâmina de Rosana Kolb. Imagens e gráficos do próprio autor. 

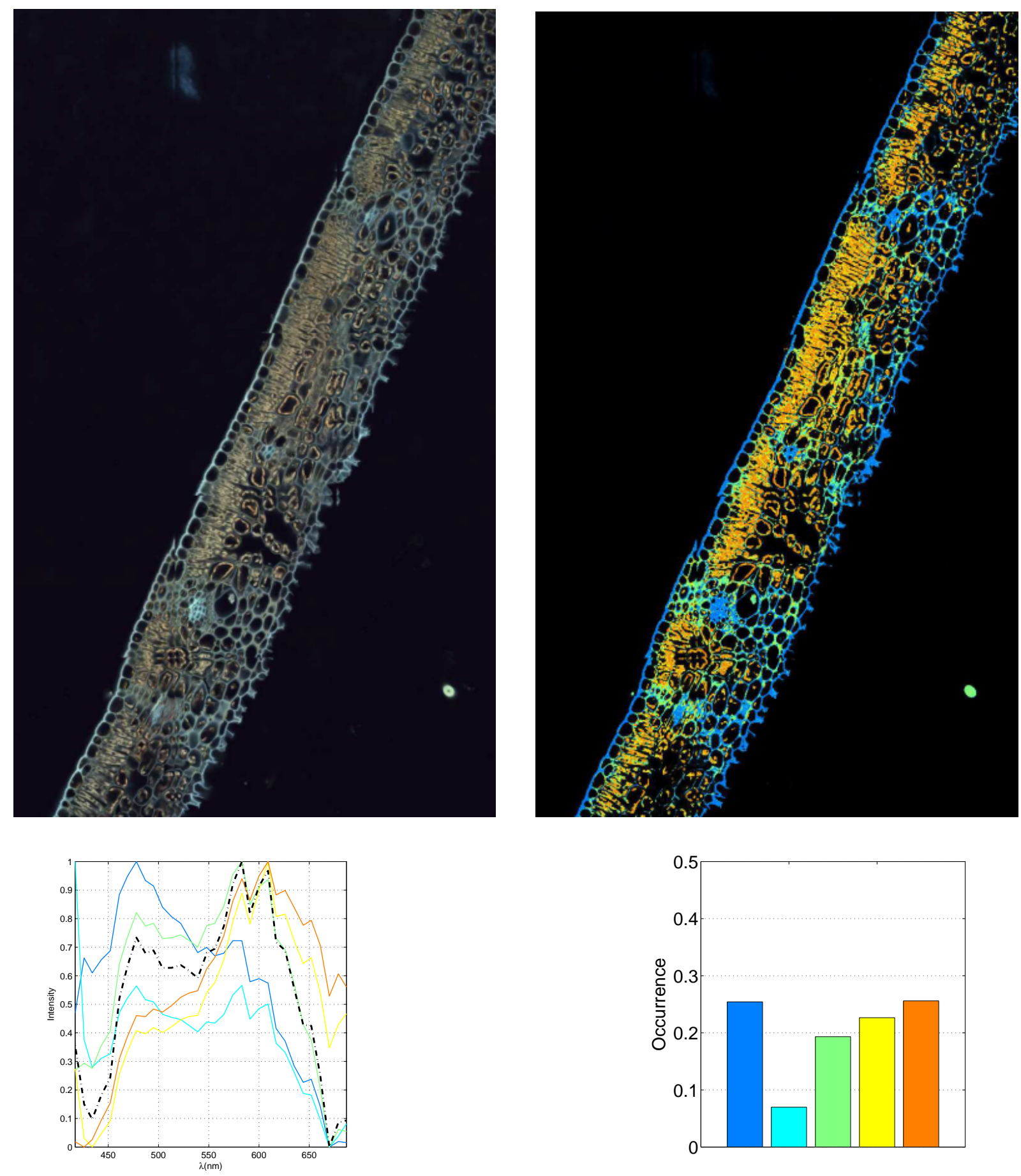

Figura 6.30-Aspidospema subincanum.

Fonte(s): Lâmina de Rosana Kolb. Imagens e gráficos do próprio autor. 

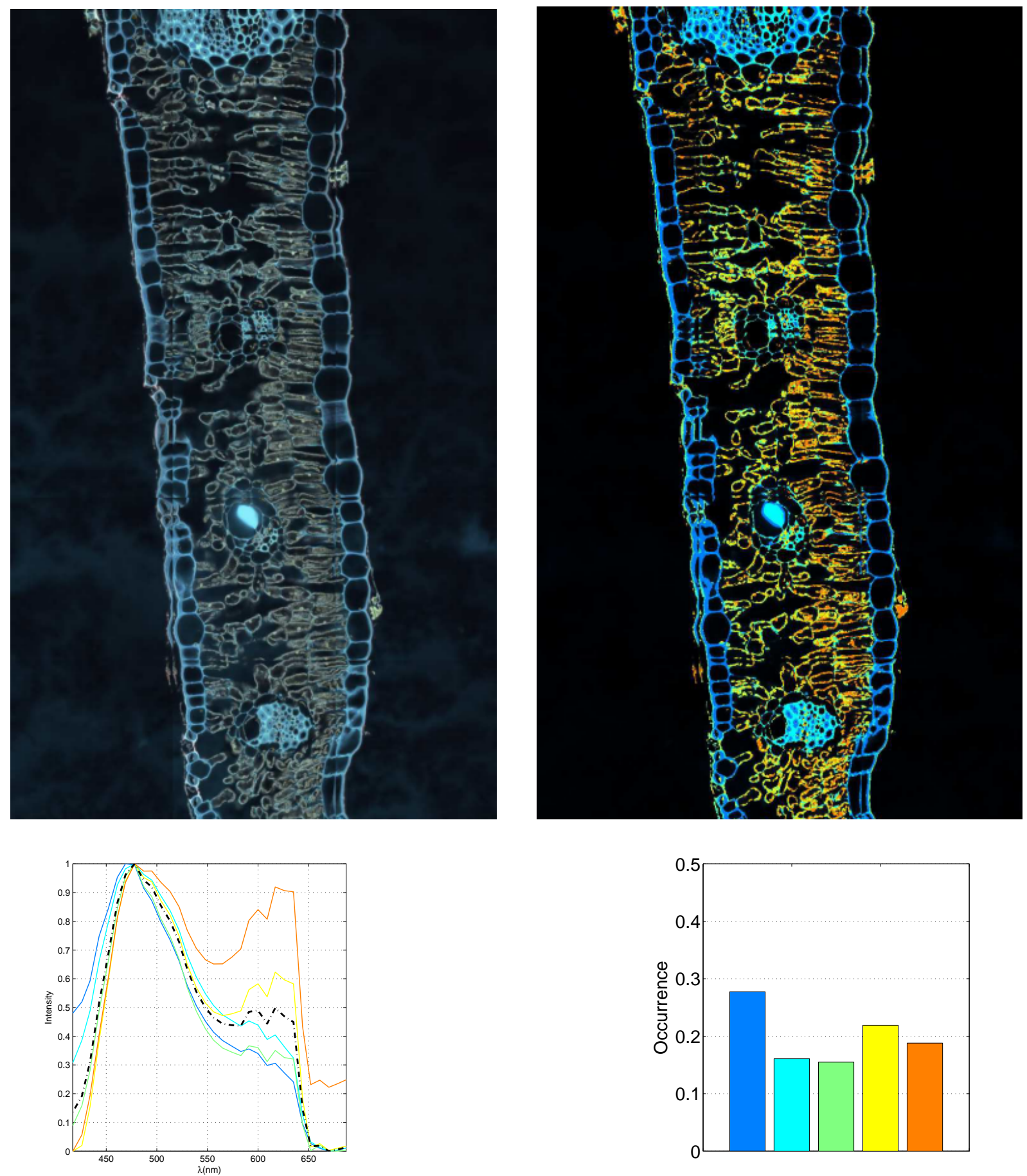

Figura 6.31-Baccharis salzmannii.

Fonte(s): Lâmina de Rosana Kolb. Imagens e gráficos do próprio autor. 

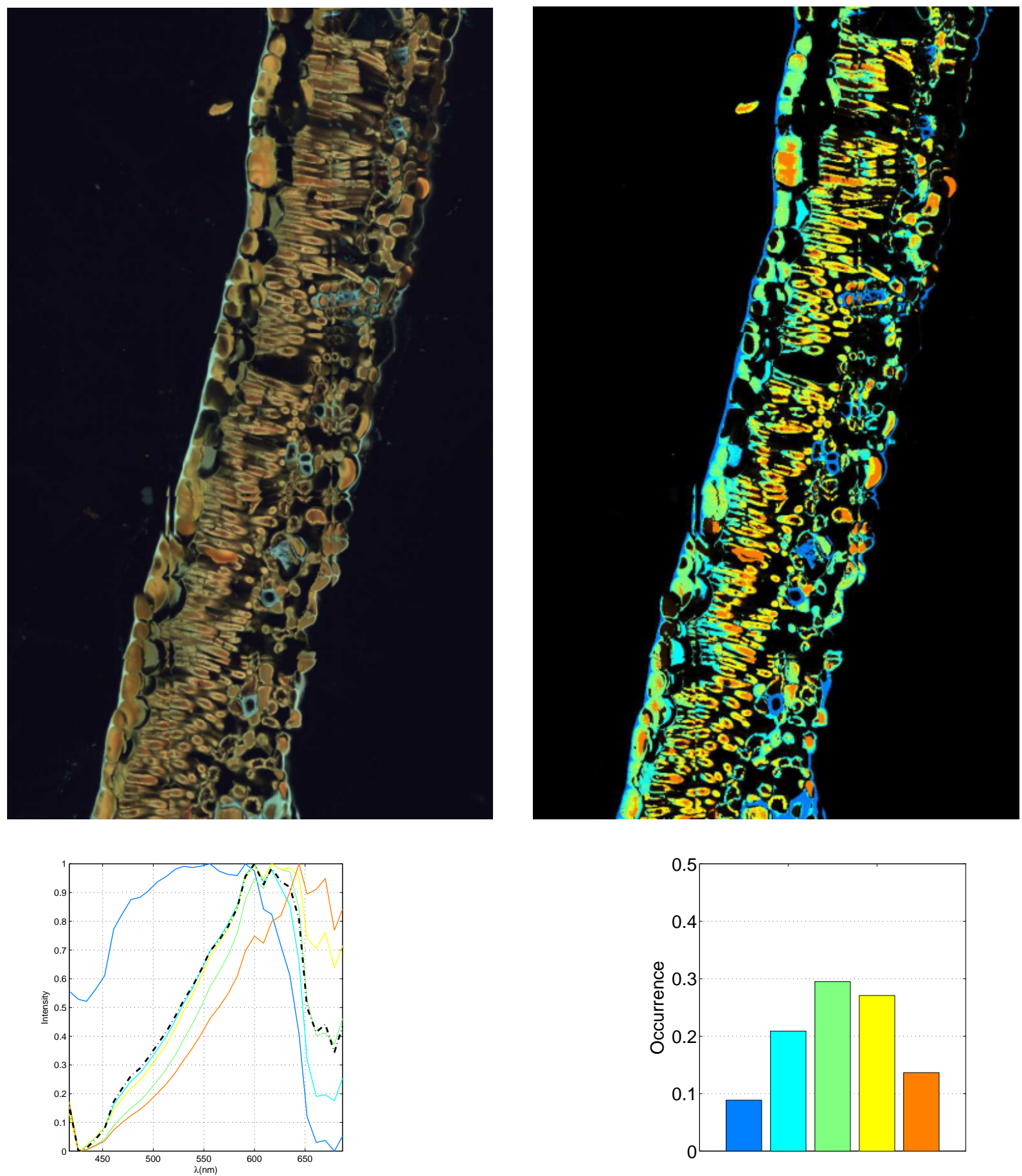

Figura 6.32-Banisteriopsis stellaris.

Fonte(s): Lâmina de Rosana Kolb. Imagens e gráficos do próprio autor. 

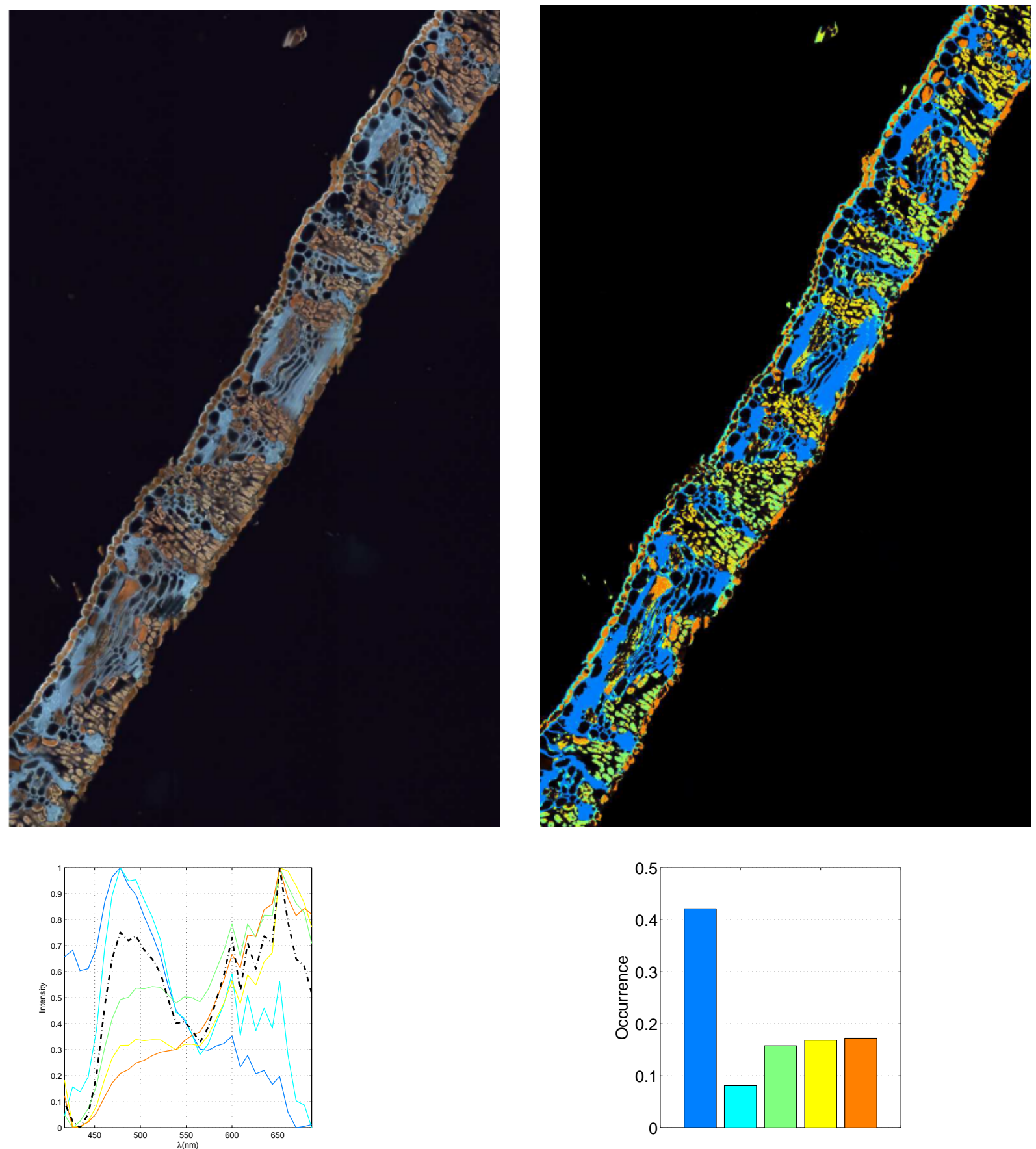

Figura 6.33- Bauhinia pulchella.

Fonte(s): Lâmina de Rosana Kolb. Imagens e gráficos do próprio autor. 

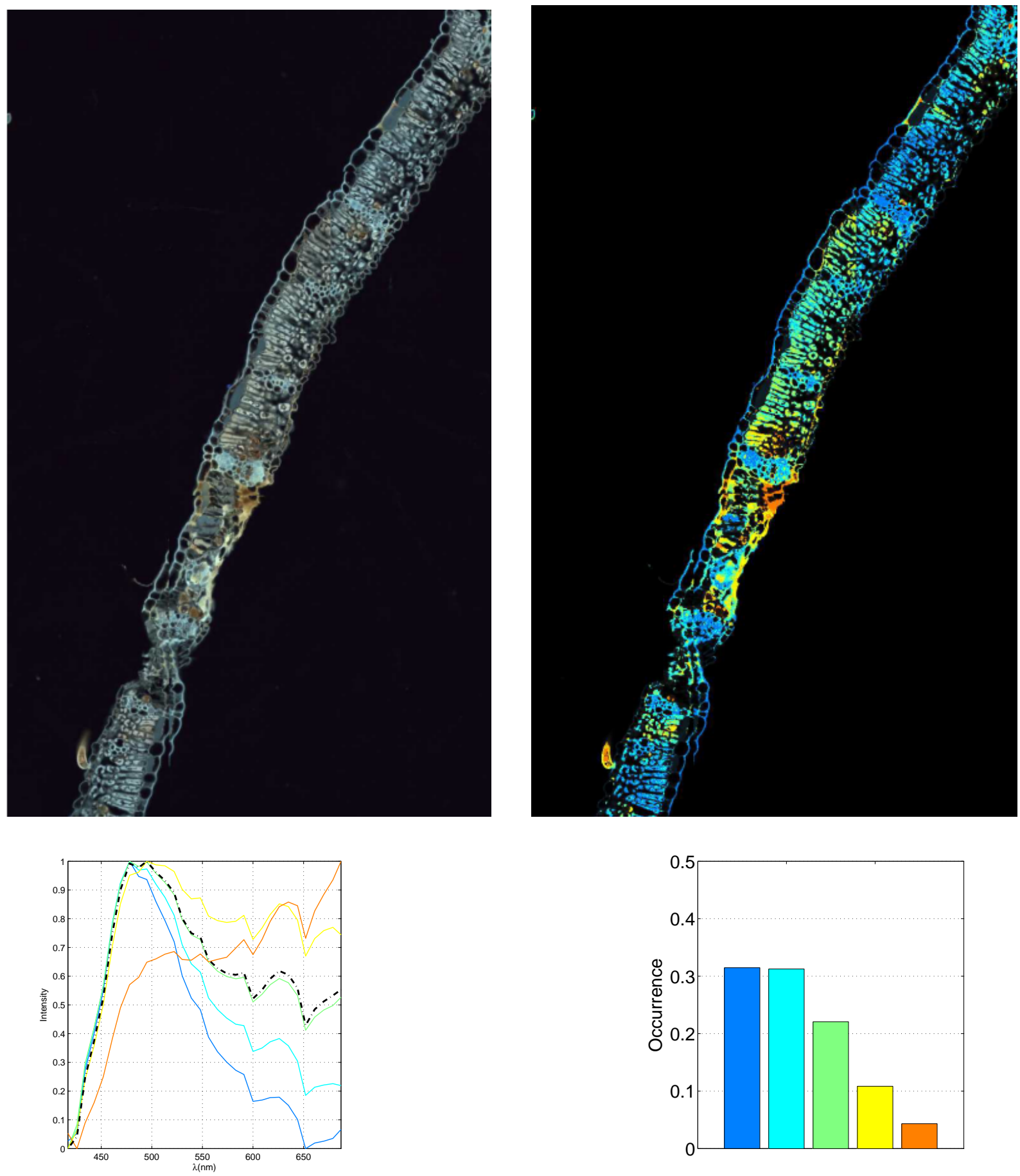

Figura 6.34-Bauhinia ungulata.

Fonte(s): Lâmina de Rosana Kolb. Imagens e gráficos do próprio autor. 

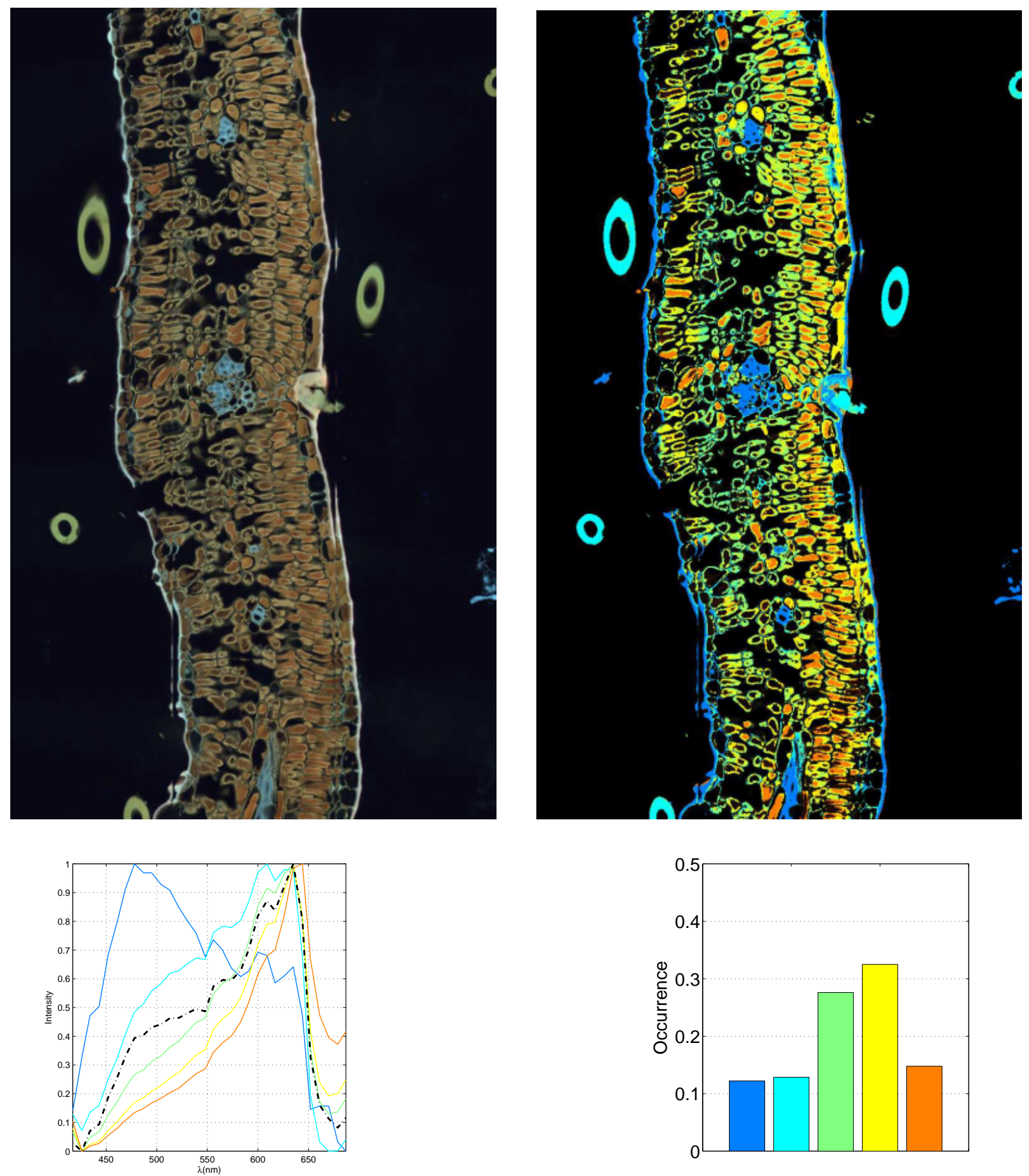

Figura 6.35-Byrsonima subterranea.

Fonte(s): Lâmina de Rosana Kolb. Imagens e gráficos do próprio autor. 

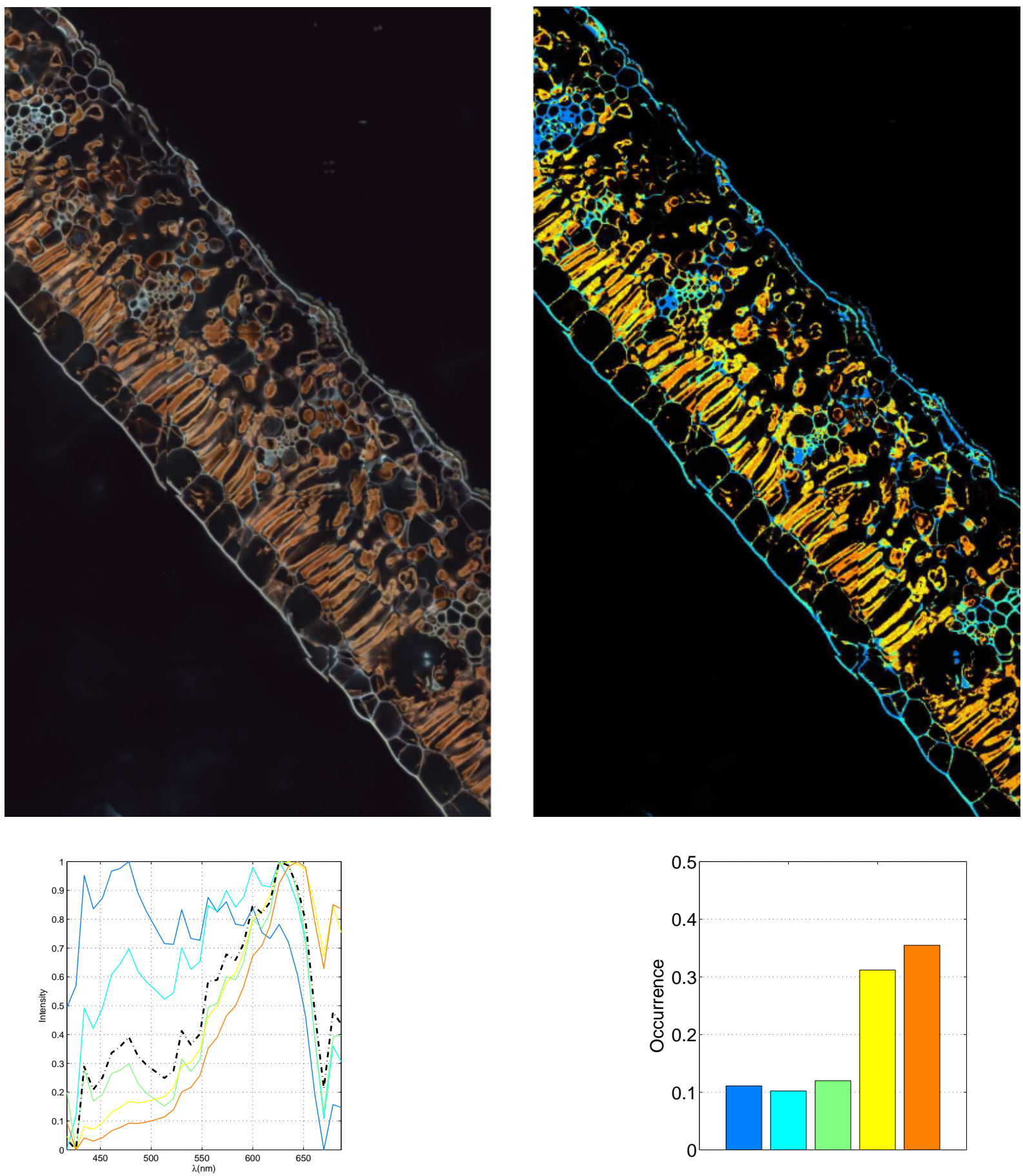

Figura 6.36-Cavanillesia arborea.

Fonte(s): Lâmina de Rosana Kolb. Imagens e gráficos do próprio autor. 

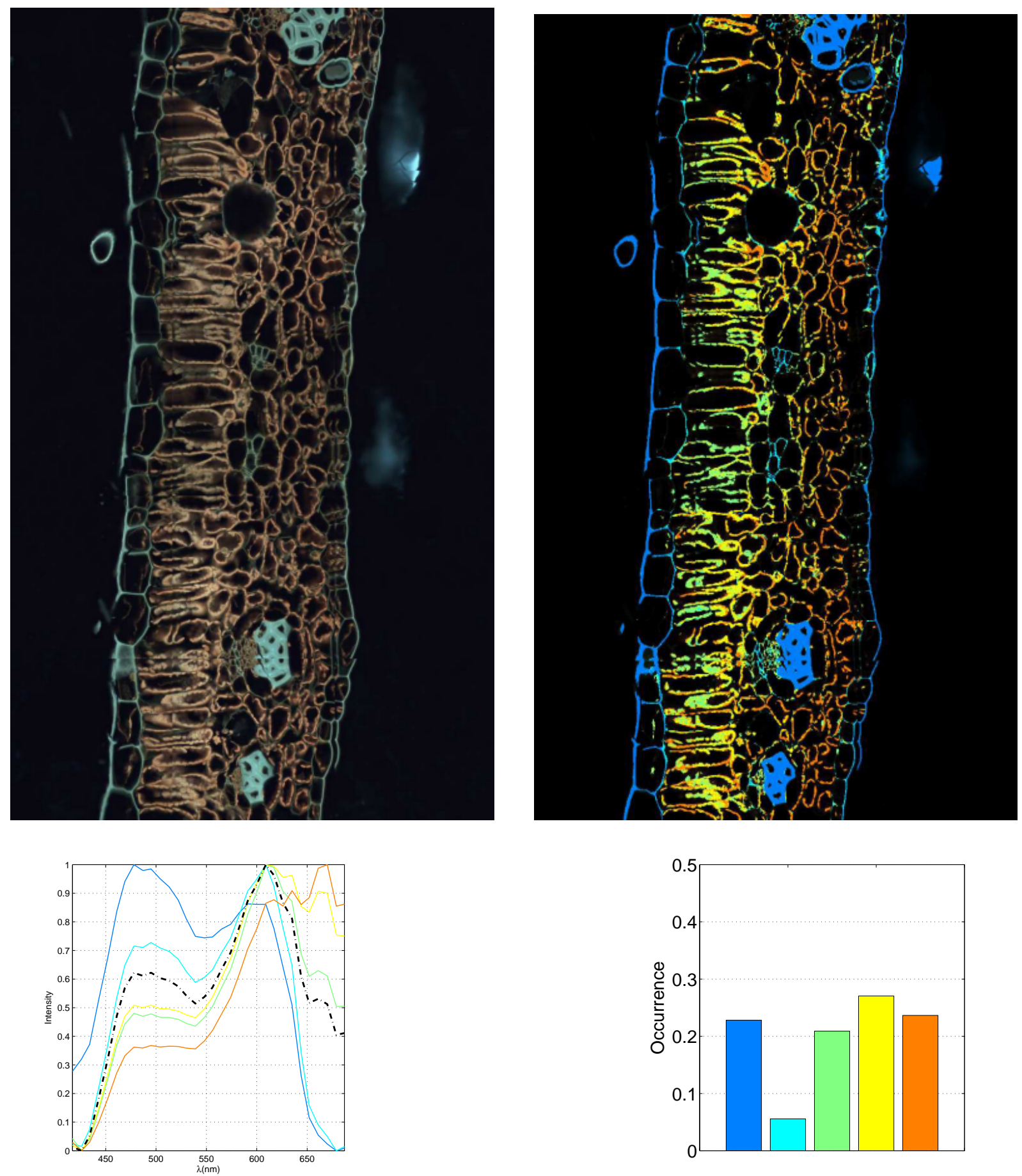

Figura 6.37-Cissus erosa.

Fonte(s): Lâmina de Rosana Kolb. Imagens e gráficos do próprio autor. 

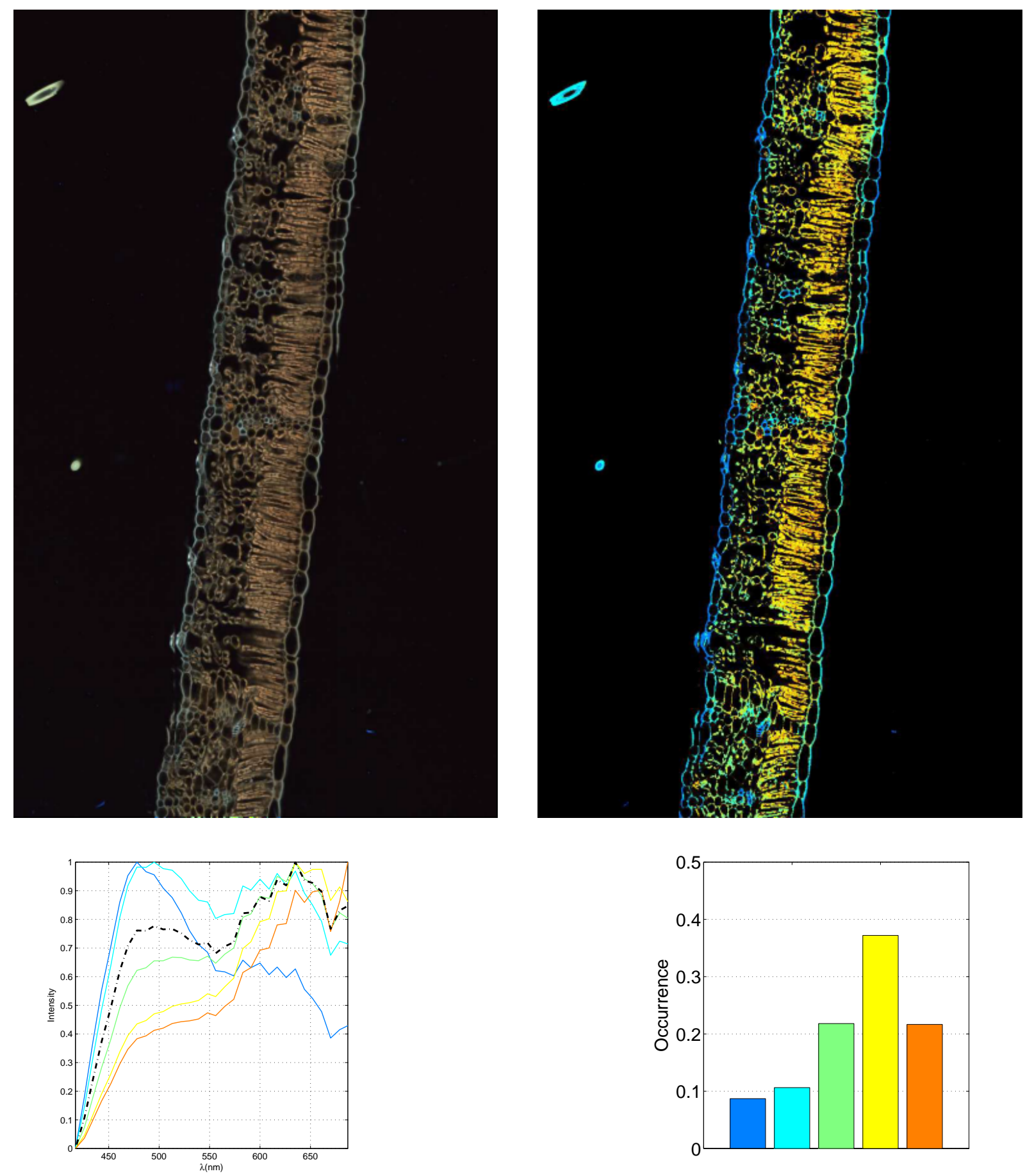

Figura 6.38-Cnidosculos urens.

Fonte(s): Lâmina de Rosana Kolb. Imagens e gráficos do próprio autor. 

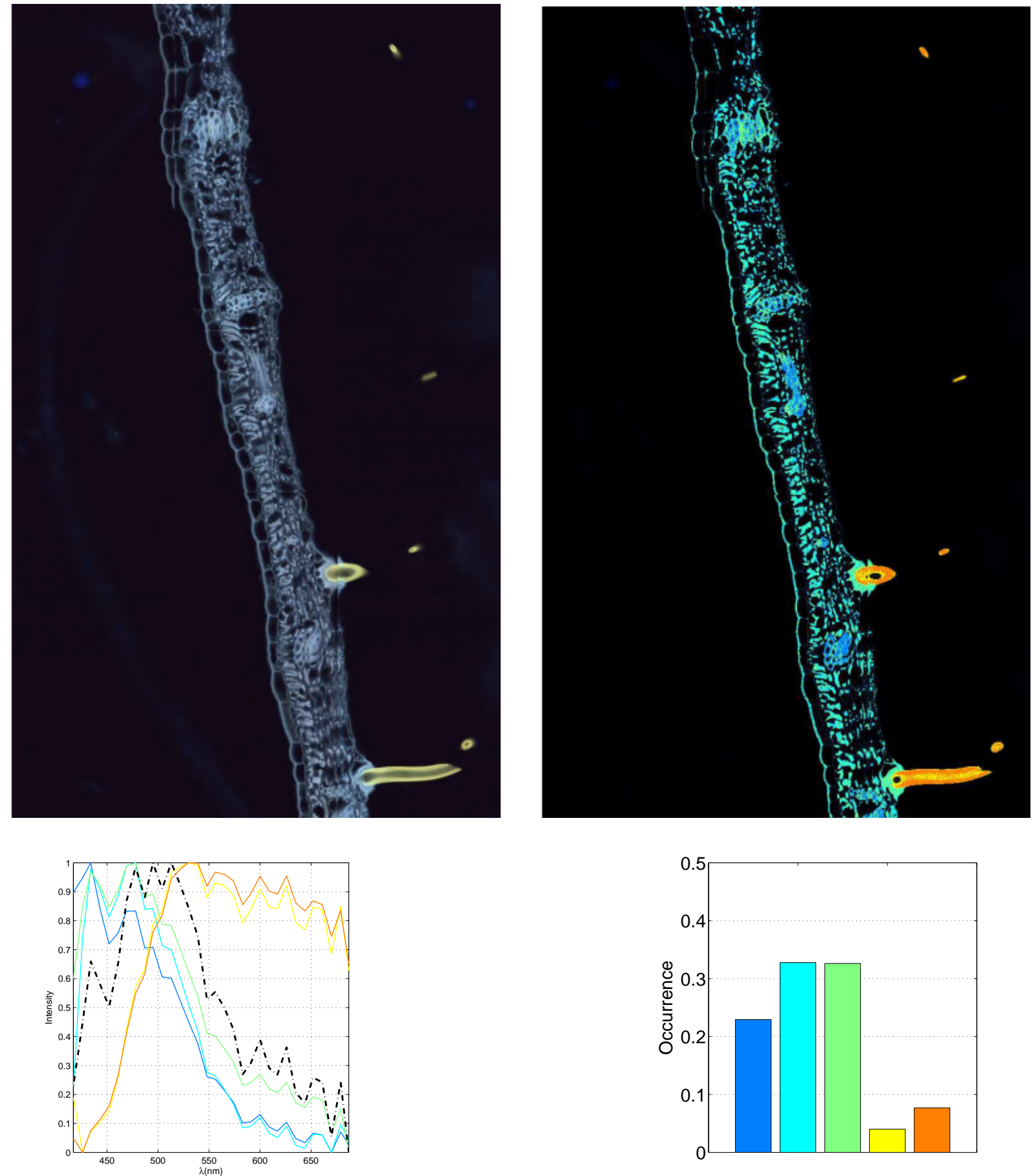

Figura 6.39-Combretum duarteanum.

Fonte(s): Lâmina de Rosana Kolb. Imagens e gráficos do próprio autor. 

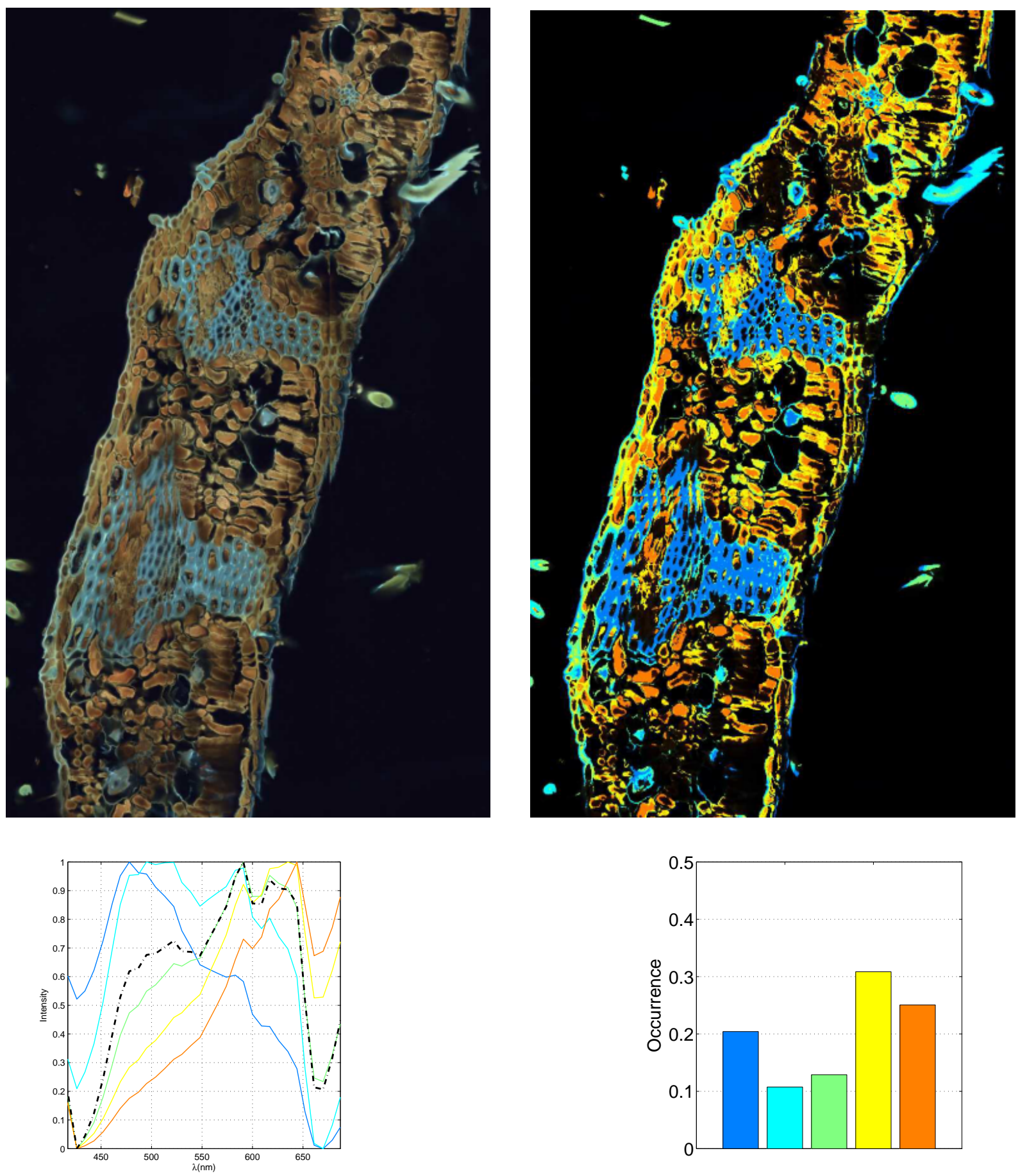

Figura 6.40-Davilla elliptica.

Fonte(s): Lâmina de Rosana Kolb. Imagens e gráficos do próprio autor. 

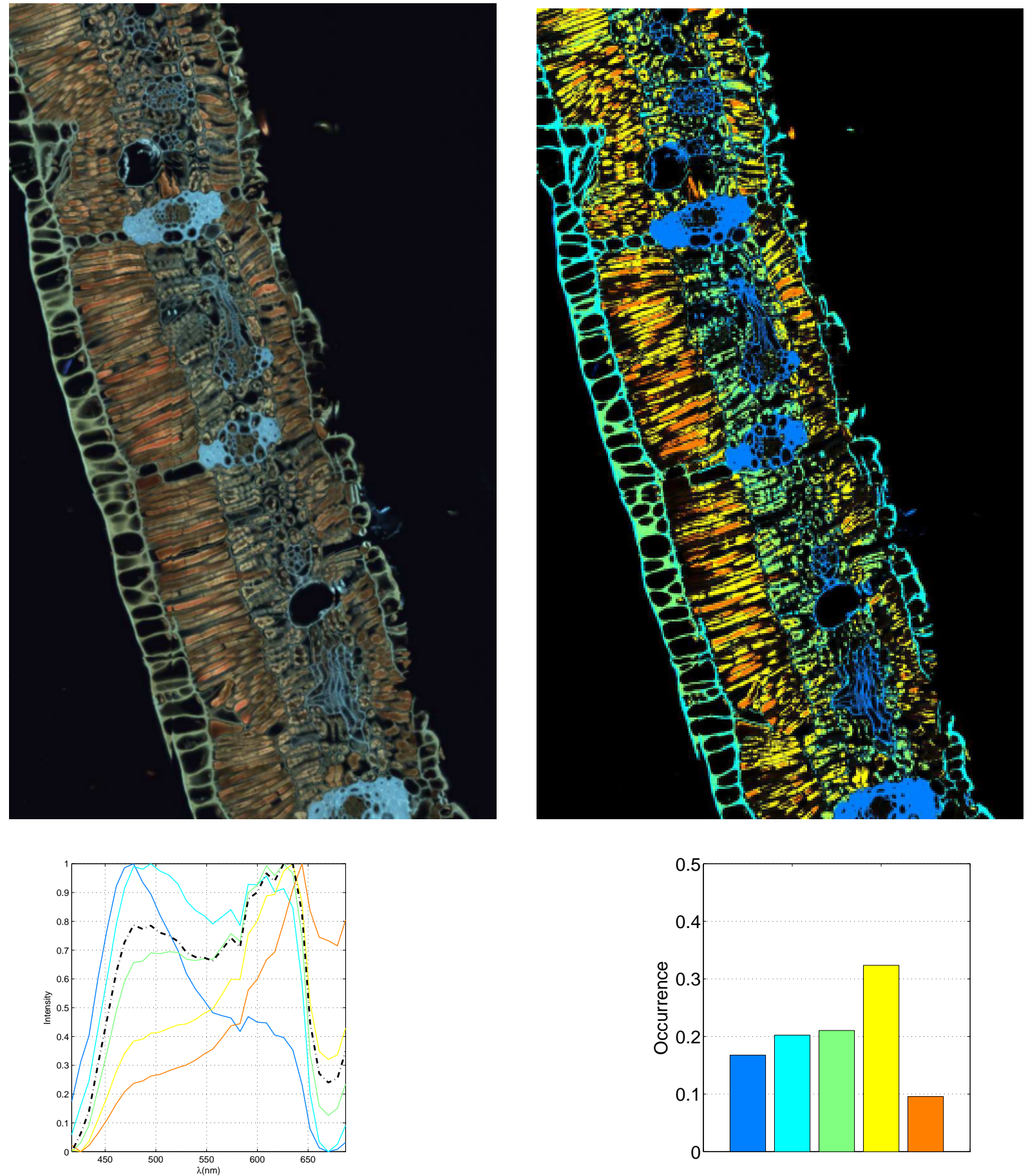

Figura 6.41-Duguetia furfuracea.

Fonte(s): Lâmina de Rosana Kolb. Imagens e gráficos do próprio autor. 

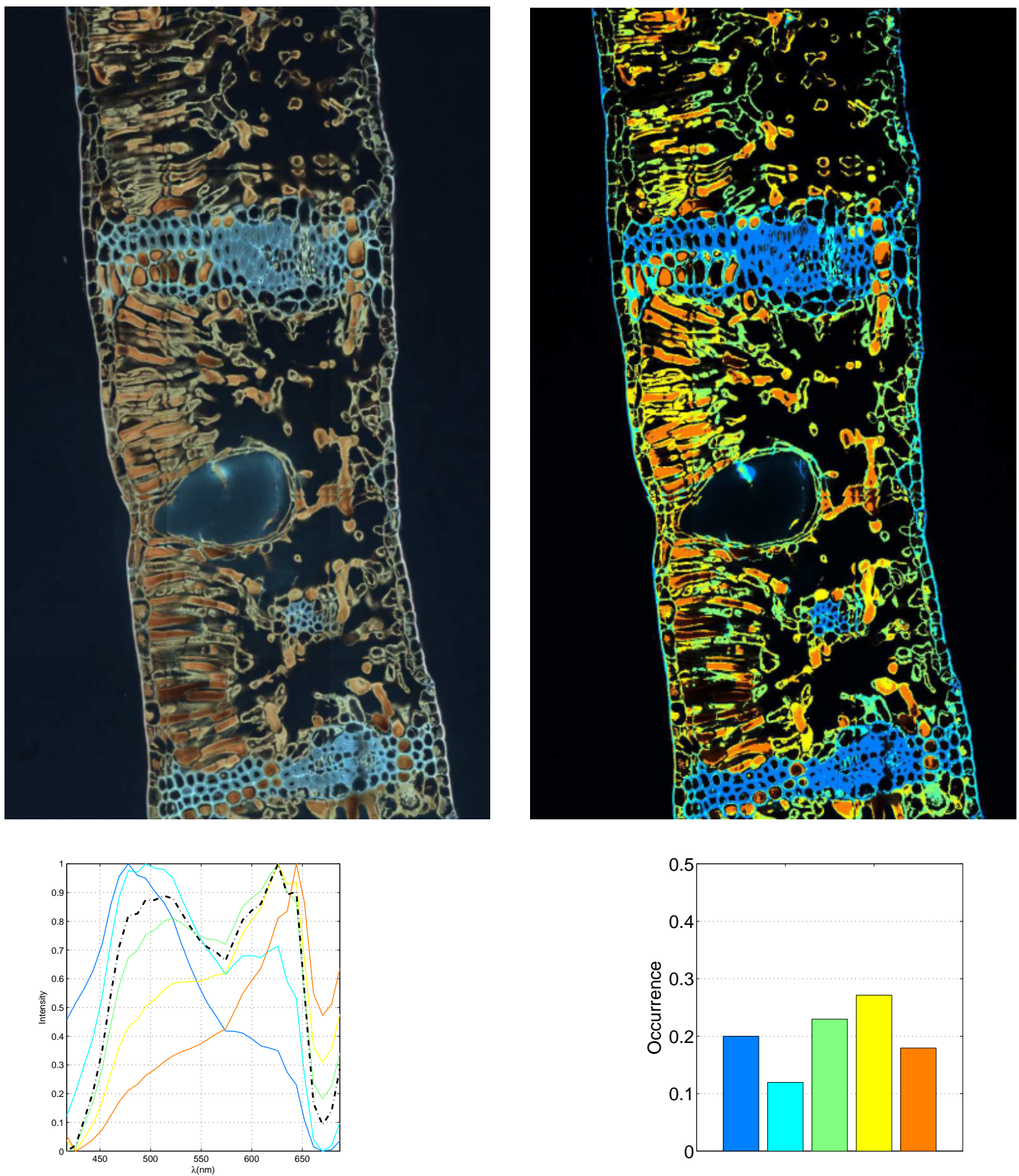

Figura 6.42-Esenbeckia pumila.

Fonte(s): Lâmina de Rosana Kolb. Imagens e gráficos do próprio autor. 

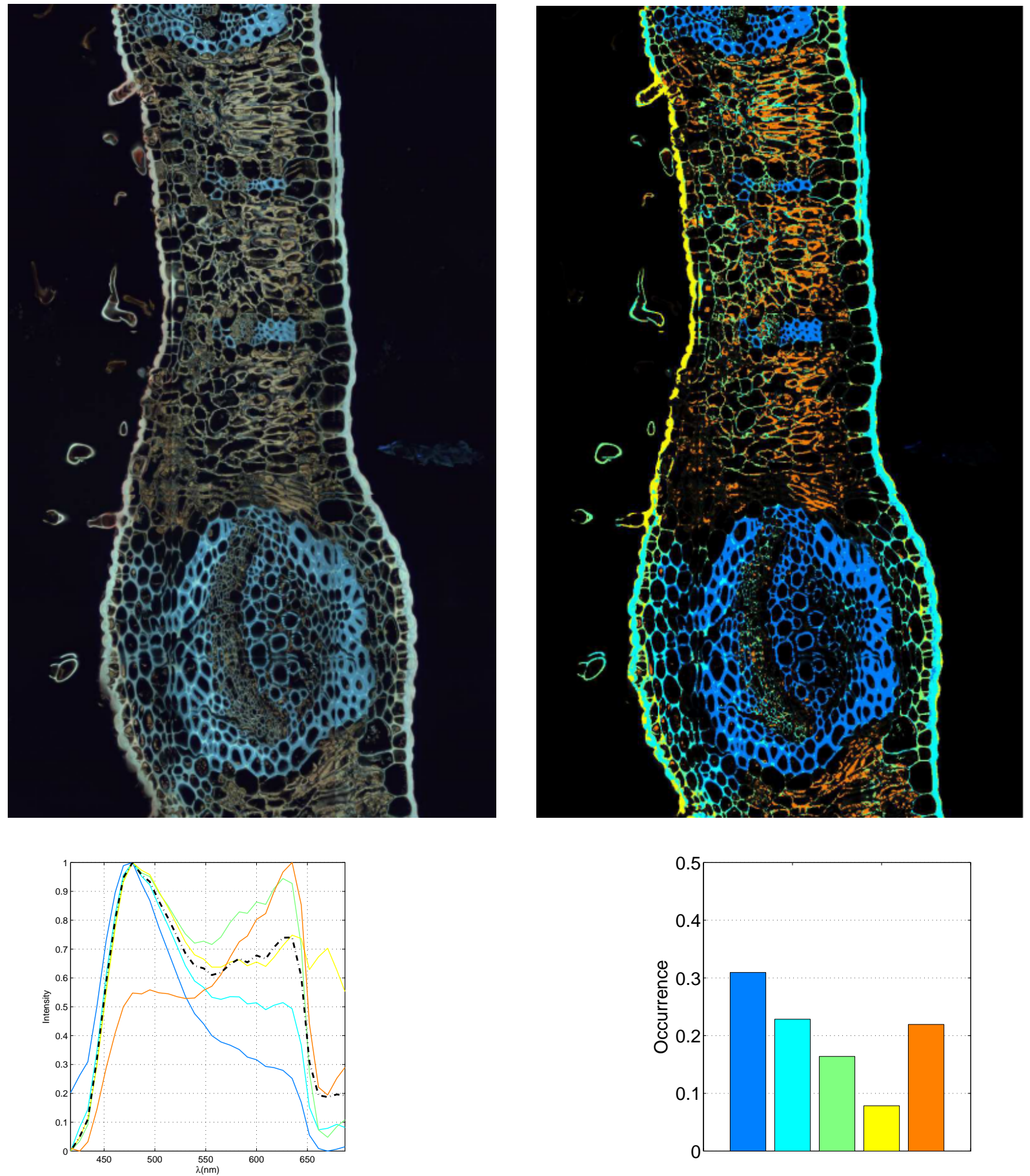

Figura 6.43-Guapira noxia.

Fonte(s): Lâmina de Rosana Kolb. Imagens e gráficos do próprio autor. 

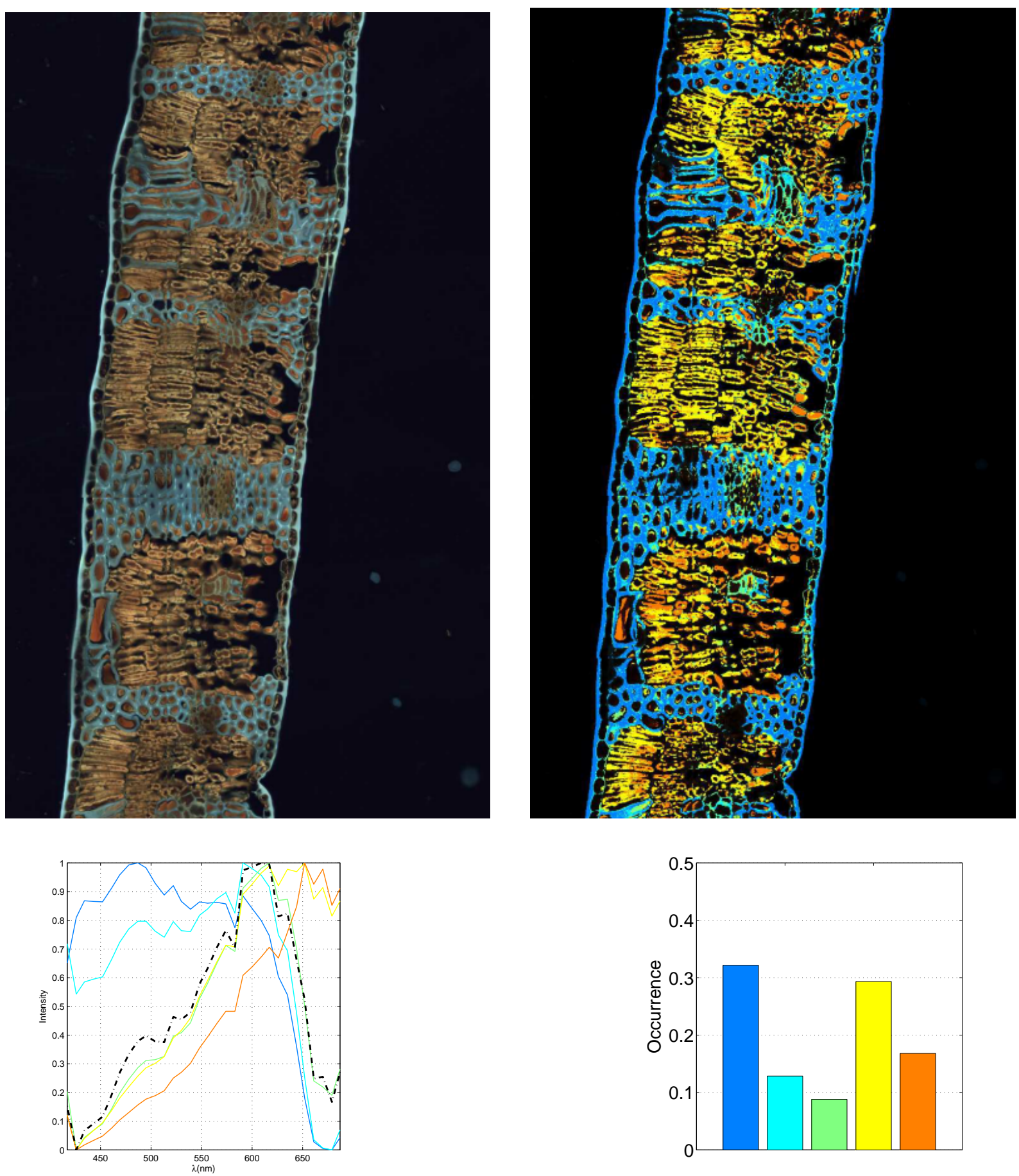

Figura 6.44-Kielmeyera abdita.

Fonte(s): Lâmina de Rosana Kolb. Imagens e gráficos do próprio autor. 

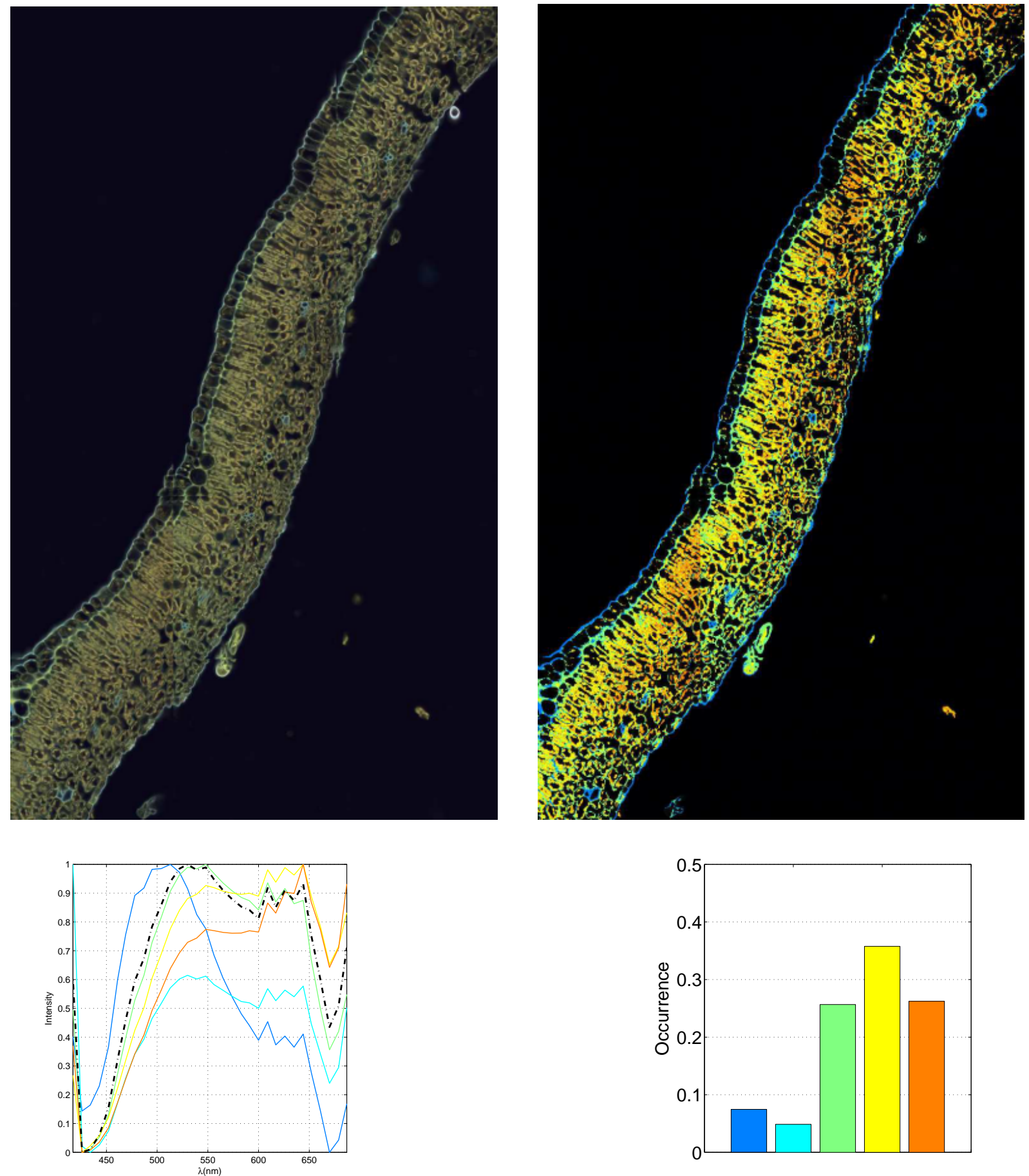

Figura 6.45- Leandra erostrata.

Fonte(s): Lâmina de Rosana Kolb. Imagens e gráficos do próprio autor. 

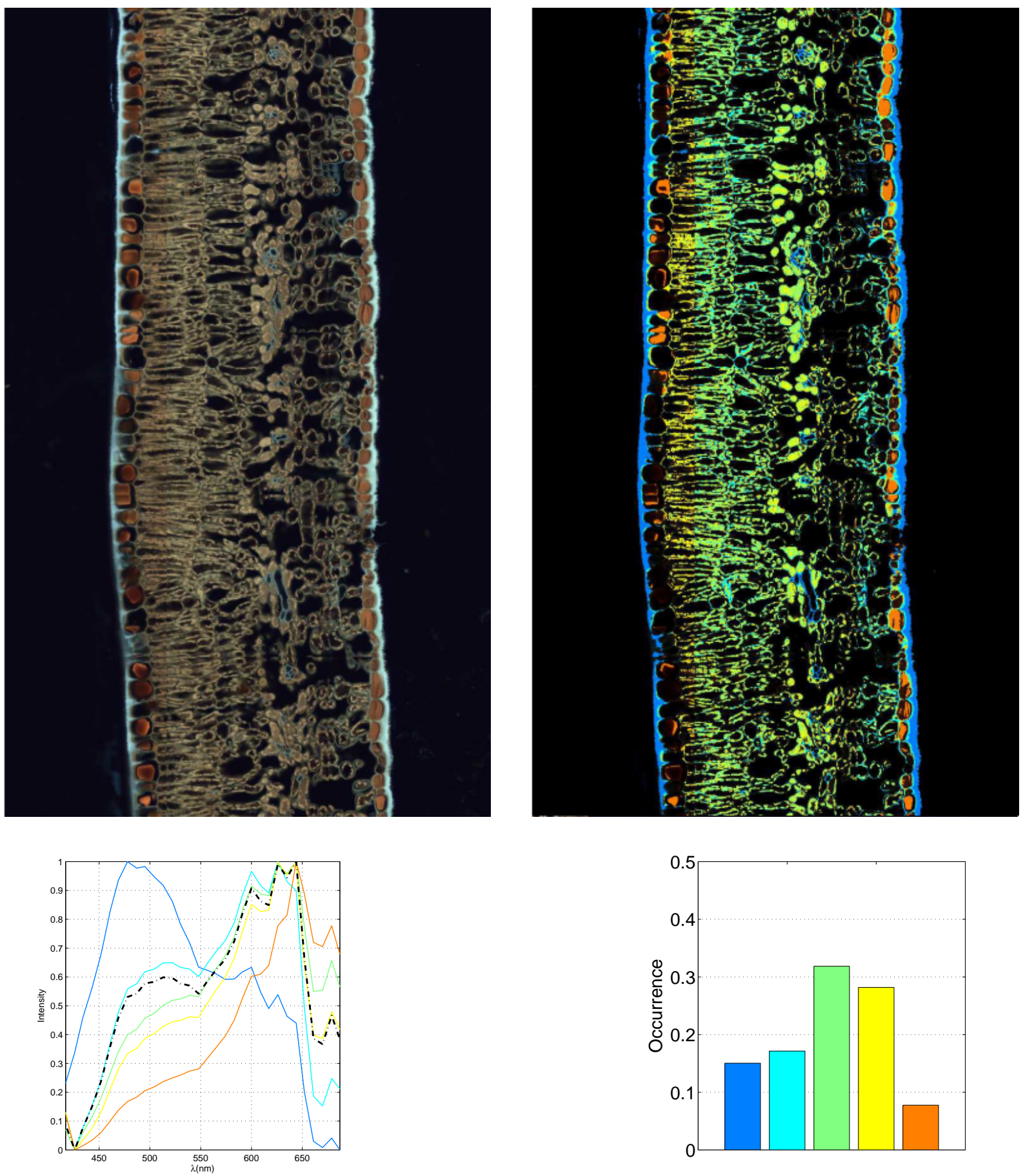

Figura 6.46- Maprounea brasiliensis.

Fonte(s): Lâmina de Rosana Kolb. Imagens e gráficos do próprio autor. 

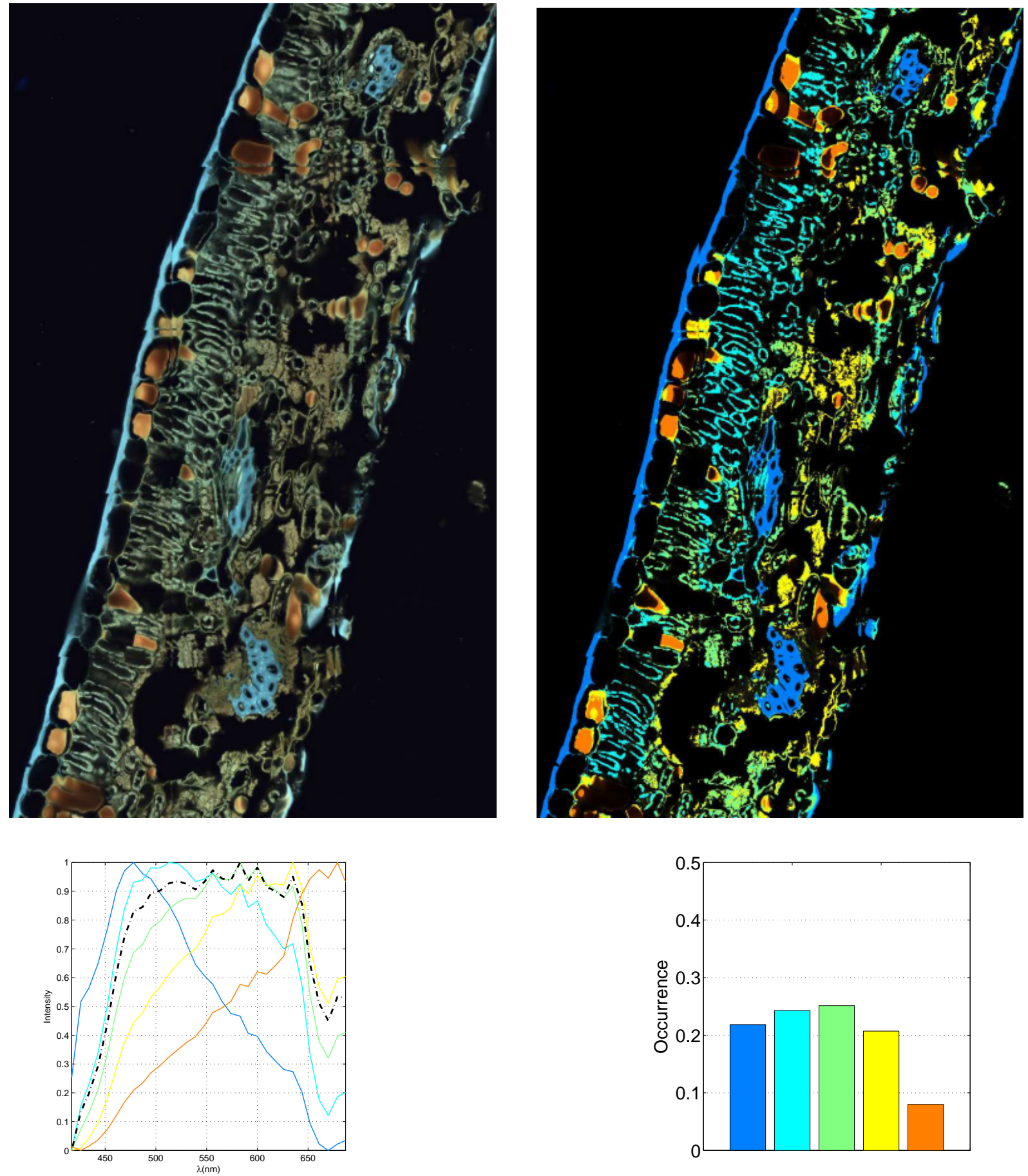

Figura 6.47-Passiflora clathrata.

Fonte(s): Lâmina de Rosana Kolb. Imagens e gráficos do próprio autor. 

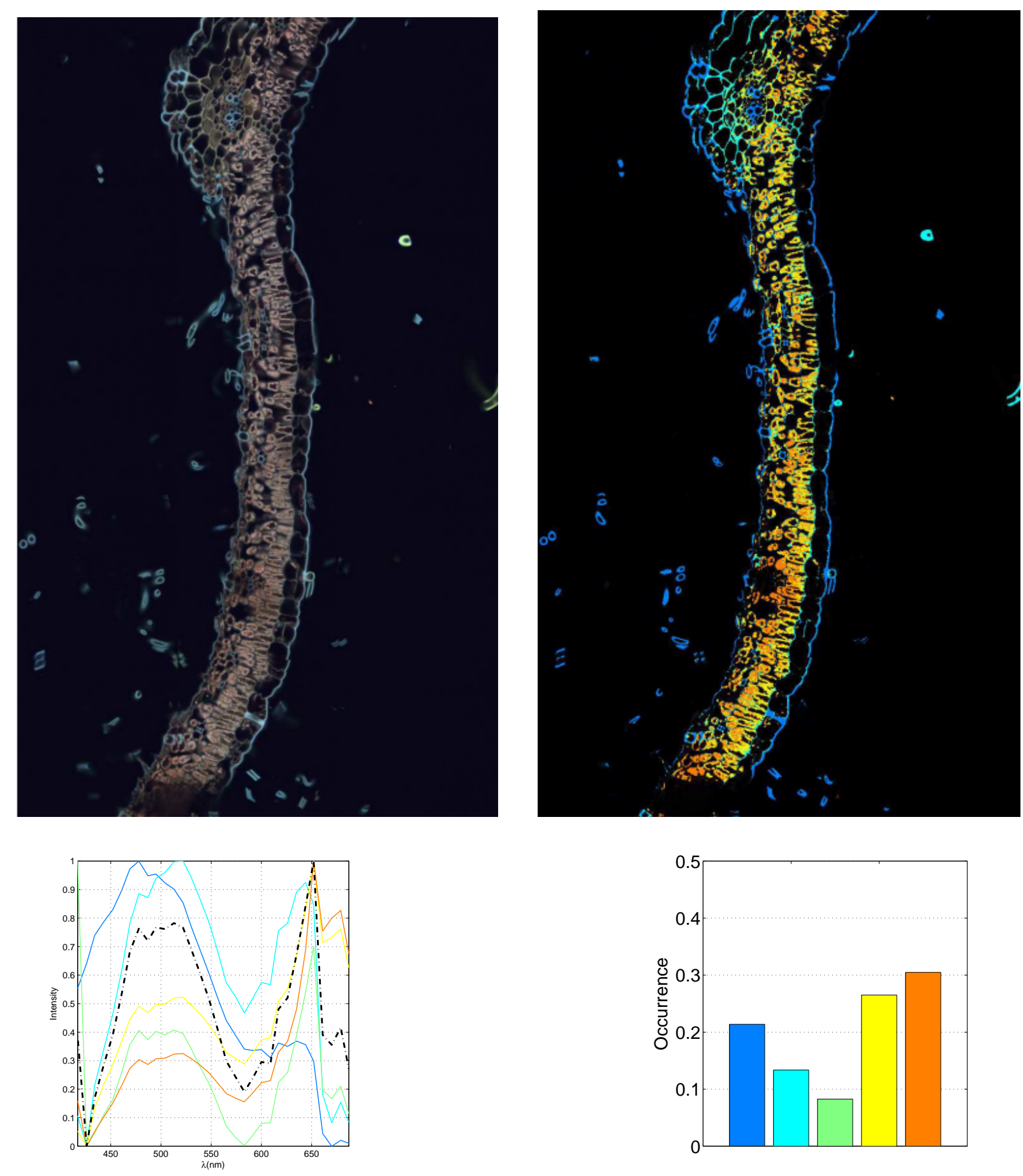

Figura 6.48-Sabicea brasiliensis.

Fonte(s): Lâmina de Rosana Kolb. Imagens e gráficos do próprio autor. 

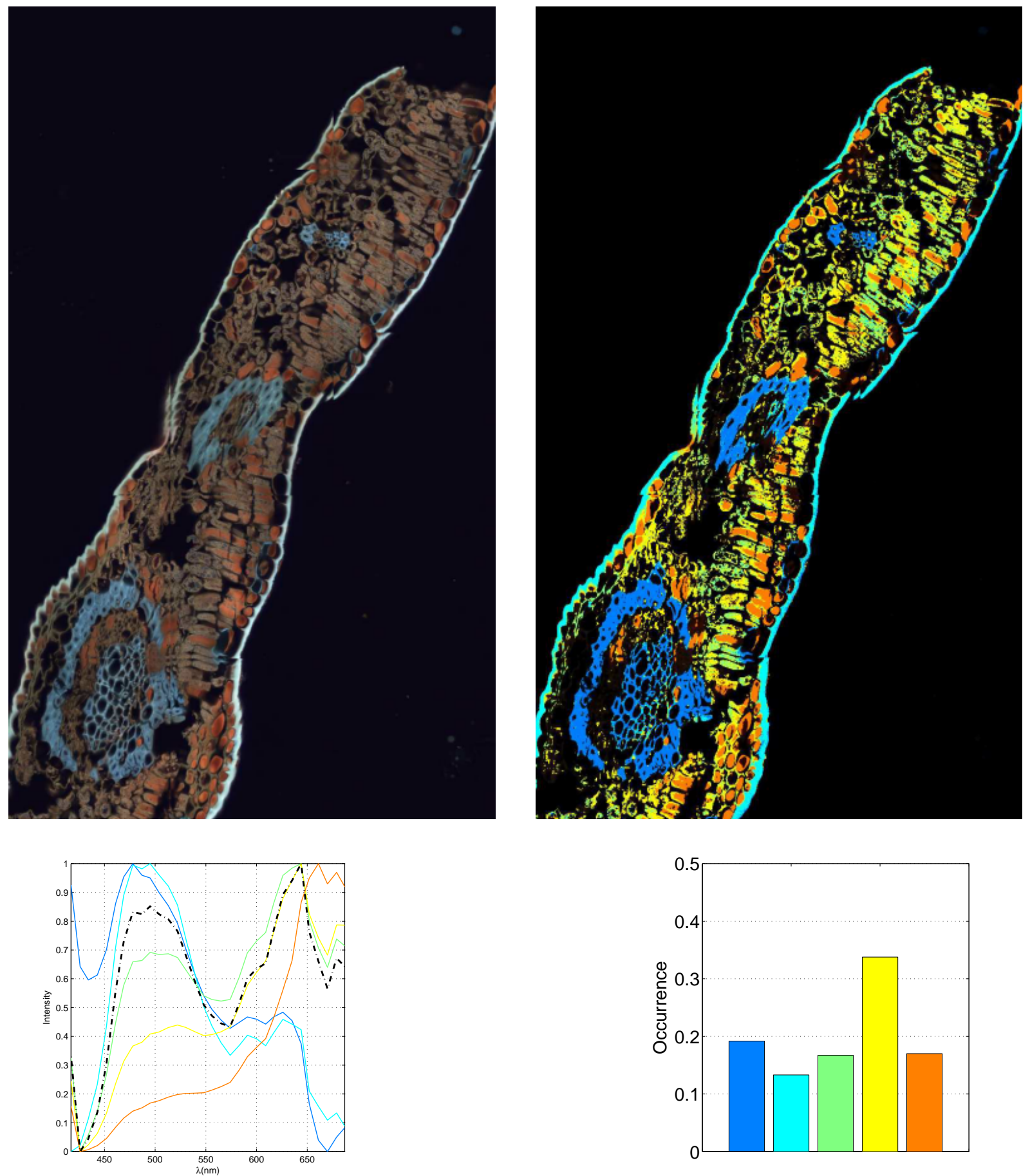

Figura 6.49-Serjania lethalis.

Fonte(s): Lâmina de Rosana Kolb. Imagens e gráficos do próprio autor. 

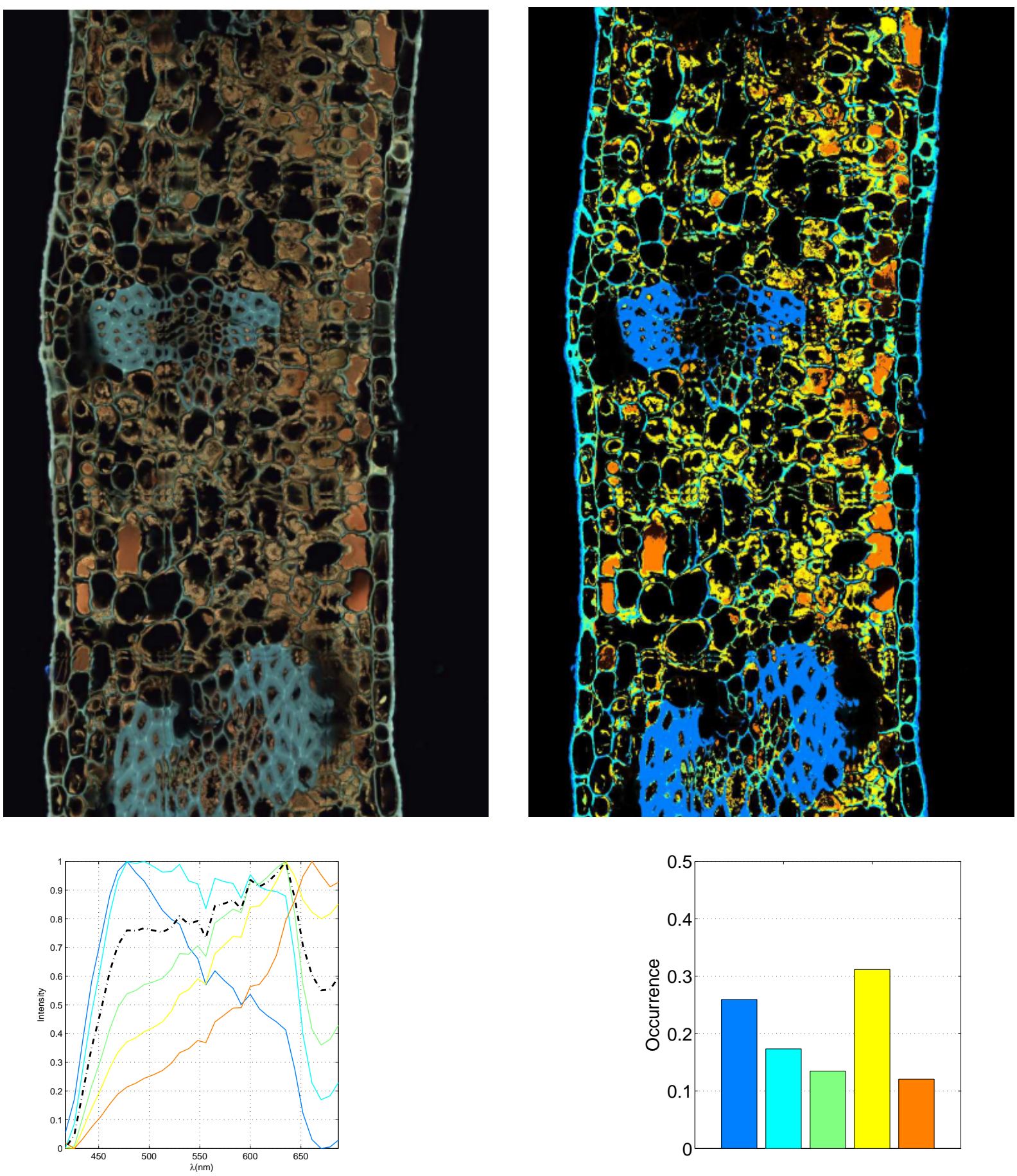

Figura 6.50-Smilax campestris.

Fonte(s): Lâmina de Rosana Kolb. Imagens e gráficos do próprio autor. 

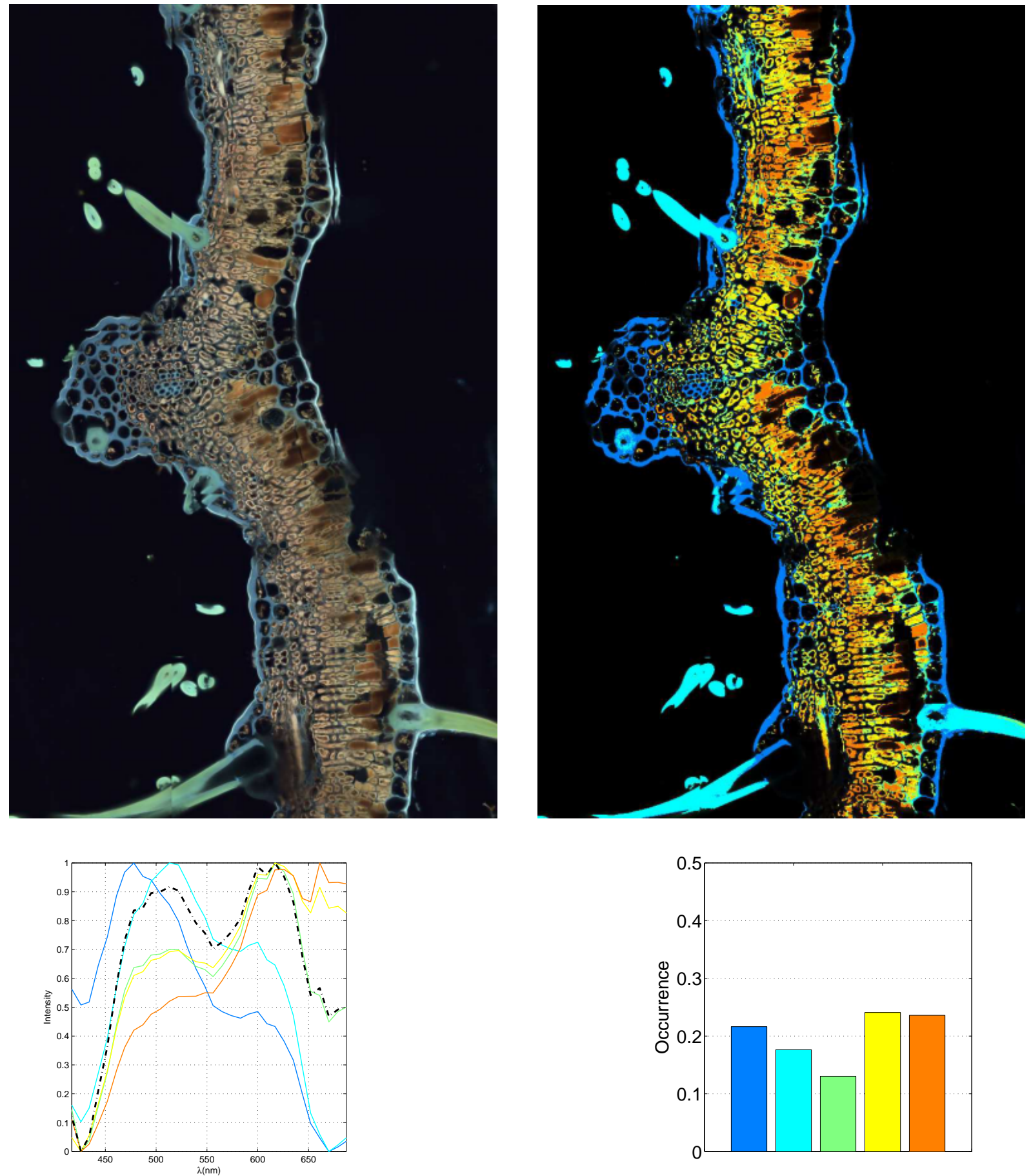

Figura 6.51-Tocoyena formosa.

Fonte(s): Lâmina de Rosana Kolb. Imagens e gráficos do próprio autor. 

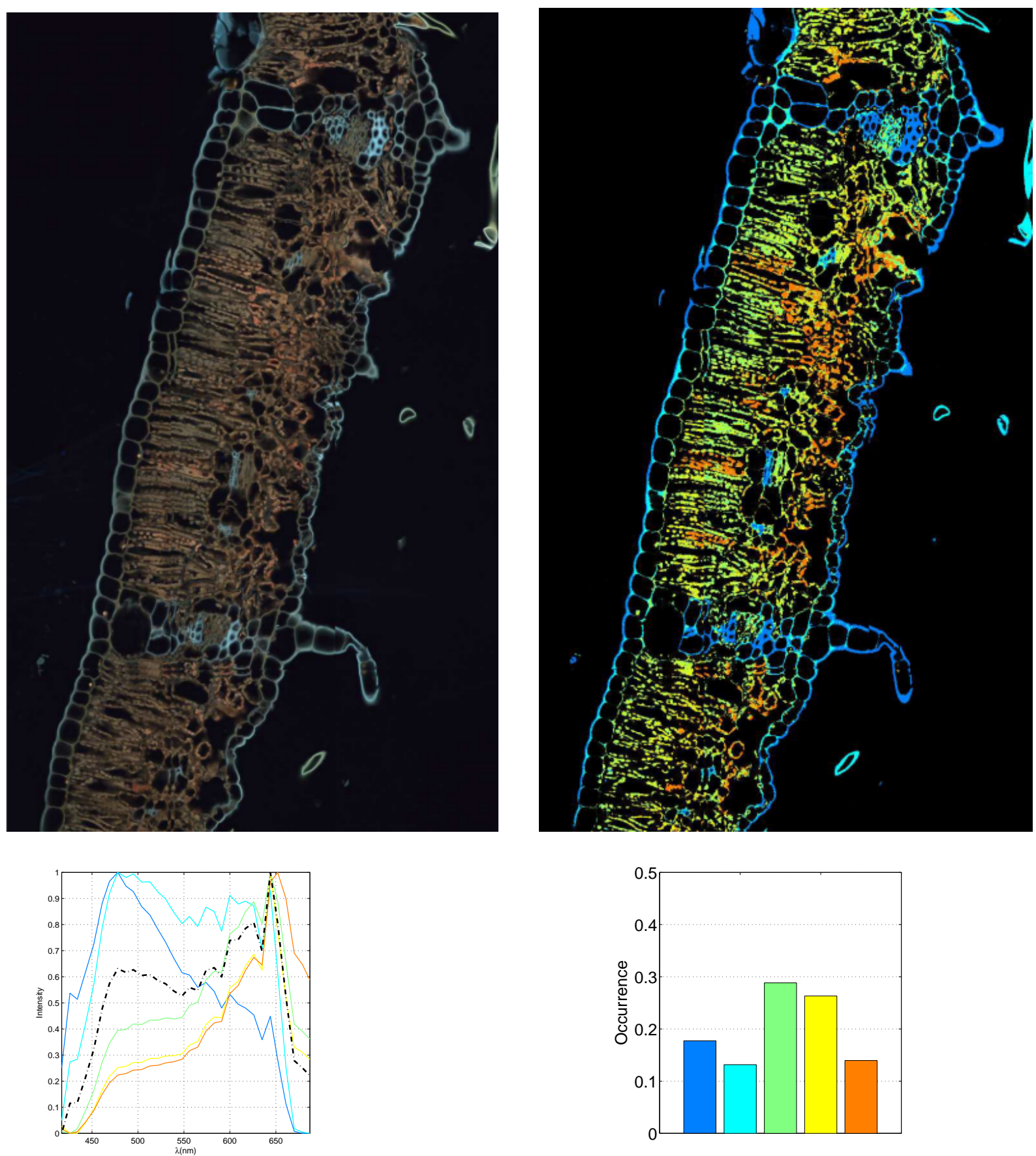

Figura 6.52- Vernonia sp.

Fonte(s): Lâmina de Rosana Kolb. Imagens e gráficos do próprio autor. 

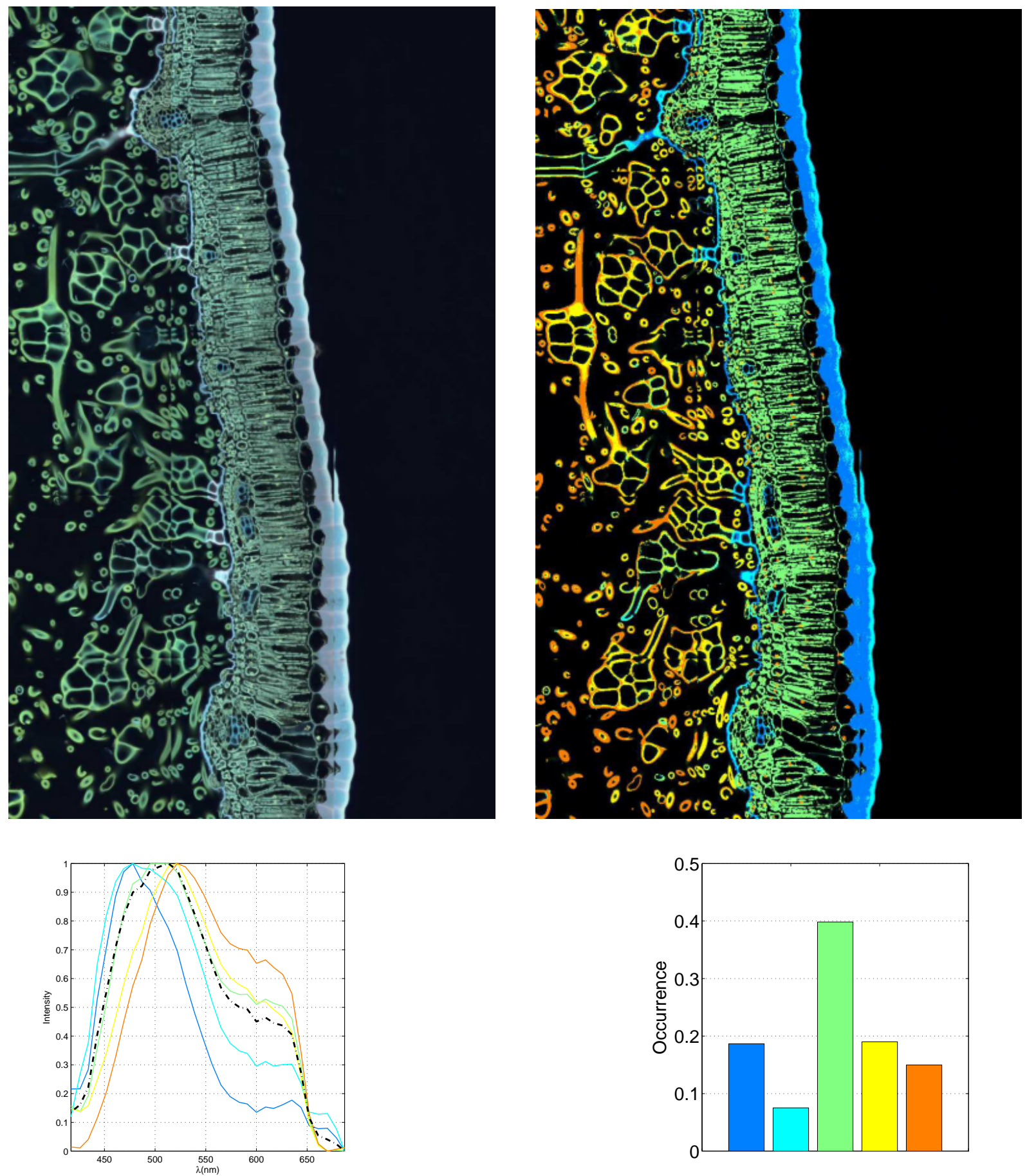

Figura 6.53-Zeyheria montana.

Fonte(s): Lâmina de Rosana Kolb. Imagens e gráficos do próprio autor. 


\section{CAPÍTULO 7}

\section{Conclusões}

Nesta tese foi proposto um método de mapeamento de imagens multiespectrais, que permite um avanço na abordagem de visualização, extração e análise de informações em imagens multiespectrais. O método tem como base o agrupamento de assinaturas multiespectrais similares, com o uso de um classificador não supervisionado (Kmeans).

Pelo fato de cada assinatura estar associada a uma coordenada da imagem multiespectral, torna-se possível a construção de uma imagem segmentada dessas regiões, relacionadas a amostra. Outro ponto importante do método é a associação das assinaturas espectrais médias e respectivas regiões segmentadas, a uma paleta de cores, definidas com base no distanciamento de cada assinatura média, ao comprimento de onda de $417 \mathrm{~nm}$ (extremo esquerdo do espectro visível). Este critério permite comparar visualmente o deslocamento espectral de cada assinatura média, nos gráficos de curvas espectrais e, localizar sua ocorrência nas respectivas regiões da imagem segmentada.

As contribuições trazidas nesta tese, com relação ao tratamento de imagens multiespectrais são: informação espectral focada na informação espectral do pixel, não mais dependendo de uma seleção de região, em uma imagem RGB; mapeamento completo da imagem multiespectral sem interferência humana, definindo-se uma paleta de cores coerente com os deslocamentos espectrais em relação ao extremo do espectro visível e associando o mapeamento com suas respectivas curvas espectrais e histograma de ocorrência espectral; quantificação dos tipos de espectros presentes na amostra - o método permite a quantificação de ocorrência de cada espectro na amostra, e sua visualização por meio de um histograma de ocorrência espectral e; mapeamento múltiplo e simultâneo de imagens multiespectrais - este recurso permite que amostras distintas tenham o mapeamento simultâneo de seus espectros, permitindo uma comparação direta entre as assinaturas espectrais das amostras e de suas ocorrências.

Referente aos estudos realizadas, seu uso apresentou melhorias significativas na caracterização e análise de imagens multiespectrais de tecidos vegetais, obtidas no microscópio 
confocal Zeiss LSM 780 com laser Coherent Chameleon, do Instituto de Física de São Carlos (IFSC/USP).

No mapeamento da lignina, o método desenvolvido permitiu mapear a estratificação desta na parede celular do bagaço de cana-de-açúcar - embora tal propriedade já fosse conhecida por métodos indiretos, esta foi a primeira vez que isto foi possível de forma direta e visualizável, sendo coerente com os modelos biológicos conhecidos, da parede celular vegetal.

Pelo mapeamento espectral foi possível realizar uma análise da plasticidade foliar do Jacaranda Caroba (o qual tem sido estudado como um bio-sensor para poluentes), cujas mudanças espectrais identificadas em amostras foliares, submetidas à diferentes concentrações de contaminante, demonstrou o potencial da planta em ser um bom indicador biológico de poluentes, quando combinada com o uso método proposto.

Por fim, testou-se o potencial do método na classificação de plantas do cerrado. O método, além de evidenciar e segmentar estruturas fisico-químicas em cortes histológicos, em níveis microscópicos, também demonstrou potencial na identificação de plantas e confirmou sua sensibilidade na detecção da plasticidade foliar.

É importante ressaltar que o método desenvolvido pode ser aplicado em qualquer área que faça uso de imagens multiespectrais, como por exemplo: Física, Química, Biologia, Medicina, Astronomia e outras. 


\section{REFERÊNCIAS}

1 GONZALEZ, R. C.; WOODS, R. E. Processamento digital de imagens. 3. ed. São Paulo: Pearson Prentice Hall, 2010.

2 WITKIN, A. P. Scale-space filtering. 1983. Disponível em: <http://ijcai.org/Past\%20Proceedings/IJCAI-83-VOL-2/PDF/091.pdf>. Acesso em: 15 ago. 2014.

3 WEEKS, M. Digital signal processing using matlab and wavelets. Hingham: Innity Science Press, 2007. (Engineering series)

4 SLAVIK, J. Fluorescence probes in cellular and molecular biology. Boca Raton: CRC Press, 1994.

5 NÍVEIS de energia. 2015. Disponível em: <https://pt.wikipedia.org/wiki/Nivel de energia>. Acesso em: 18 ago. 2015.

6 BRAKENHOFF, G. J.; SPROSEN, E. A. V.; VOORT, H. T. M. V. D.; NANNINGAN. Three dimensional confocal fluorescence microscopy. In: TAYLOR, D. L.; WANG, Y-L. Fluorescence microscopy of living cells in culture part B. San Diego, California: Academic Press, 1989. cap. 14. p. 379-416. (Methods in cell biology, v. 30)

7 SHEPPARD, C. J. R.; CHOUDHURY, A. Image formation in the scanning microscope. Optica Acta, v. 24, n. 10, p. 1051-1073, 1977.

8 HASSIOTOU, F.; RENTON, M.; LUDWIG, M.; EVANS, J. R.; VENEKLAAS, E. J. Photosynthesis at an extreme end of the leaf trait spectrum: how does it relate to high leaf dry mass per area and associated structural parameters? Journal of Experimental Botany, v. 16, n. 11, p. 3015-3028, 2012.

9 GRIGG, S. P.; CANALES, C.; HAY, A.; TSIANTIS, M. Serrate coordinates shoot meristem function and leaf axial patterning in arabidopsis. Nature, v. 43, n. 13, p. 1022-1026, 2005.

10 CUTTER, E. G. Anatomia vegetal: células e tecidos. São Paulo: Roca, 2010.

11 CUTTER, E. G. Anatomia vegetal: órgãos experimentos e interpretação. São Paulo: Roca, 2010.

12 TOMÁs, M. et al. Importance of leaf anatomy in determining mesophyll diffusion conductance to co 2 across species: quantitative limitations and scaling up by models. Journal of Experimental Botany, v. 64, n. 8, p. 2269-2281, 2013.

13 JIN, S. H.; HUANG, J. Q.; LI, X. Q.; ZHENG, B. S.; WU, J. S.; WANG, Z. J.; LIU, G. H.;CHEN, M. Effects of potassium supply on limitations of photosynthesis by mesophyll difusion conductance in carya cathayensis. Tree Fisiology, v. 31, p. 1142-1151, 2011.

14 ZHANG, Z.; JIANG, C.; ZHANG, J.; ZHANG, H.; SHI, L. Ecophysiological evaluation of the potential invasiveness of rhus typhina in its non-native habitats. Tree Physiology, v. 29, p. 1307-1316, 2009. 
15 PETROU, M.; PETROU, C. Image processing: the fundamentals. 2nd ed. Chichester: John Wiley, 2010.

16 LINDEBERG, T. Scale-space theory in computer vision. Boston: Kluwer Academic, 1994.

17 COSTA, L. F.; CESAR JUNIOR, R. M. Shape analysis and classification: theory and practice. Boca Raton: CRC Press, 2001.

18 CESAR JUNIOR, R. M. Análise multi-escala de formas bidimensionais. 1997. 229 p. Tese (Doutorado) - Instituto de Física de São Carlos, Universidade de São Paulo, São Carlos, 1997.

19 MARR, D. Vision: a computational investigation into the human representation and processing of visual information. New York: Freeman, 1982.

20 MALLAT, S. A theory for multiresolution signal decomposition: the wavelet representation. IEEE Transaction on Pattern Analysis and Machine Intelligence, v. 11, n. 7, p. 674-693, 1989.

21 GRAPS, A. A introduction to wavelets. IEEE Computational Science \& Engineering, v.2, n. 2, p. 5061, 1995.

22 MERTINS, A. Signal analysis: wavelets, filter banks, time frequency transforms and applications. Chichester: John Wiley \& Sons, 1999.

23 AIKENS, R. S.; AGARD, D. A.; SEDAT, J. W. Solid-state imagers for microscopy. In: WANG, Y-L.; TAYLOR, D. L. Fluorescence microscopy of living cells in culture part a: fluorescence analogs, labeling cells and basic microscopy. San Diego: Academic Press, 1998. cap. 16. p. 291-313. (Methods in cell biology, v.29)

24 FORSYTH, D. A.; PONCE, J. Computer vision: a modern approach. Upper Saddle River,New Jersey: Prentice Hall, 2003.

25 TAYLOR, D. L.; SALMON, E. D. Basic fluorescence microscopy. In: WANG, Y- L.; TAYLOR, D. L. Fluorescence microscopy of living cells in culture part $a$ : fluorescence analogs, labeling cells and basic microscopy. San Diego: Academic Press, 1989. cap. 13. p. 207-237. (Methods in cell biology, v. 29)

26 WAMPLER, J. E.; KUTZ, K. Quantitative fluorescence microscopy using photomultiplier tubes and imaging detectors In: WANG, Y- L.; TAYLOR, D. L. Fluorescence microscopy of living cells in culture part $a$ : fluorescence analogs, labeling cells and basic microscopy. San Diego: Academic Press, 1989. cap. 14. p. 239-267. (Methods in cell biology, v. 29)

27 YOUNG, I. T. Image fidelity: characterizing the imaging transfer function. In: TAYLOR, D. L.; WANG, Y-L. Fluorescence microscopy of living cells in culture part b. San Diego: Academic Press, 1989. cap. 1. p. 1-45. (Methods in cell biology, v. 30).

28 ADIGA, U.; MALLADI, R.; FERNANDEZ-GONZALEZ, R.; DE SOLORZANO, C. O. High-throughput analysis of multispectral images of breast cancer tissue. IEEE Transactions on Image Processing, v. 15, n. 8, p. 2259-2268, 2006.

29 AleXOPOUlOU, A. A.; KAMINARI, A.-A.; PANAgOPOUloS, A.; PÖHLMANN, E. Multispectral documentation and image processing analysis of the papyrus of tomb II at Daphne, Greece. Journal of Archaeological Science, v. 40, n.2, p. 1242-1249, 2013. 
30 HARSANYI J. Chang C. Hyperspectral image classification and dimensionality reduction: An orthogonal subspace projection approach. IEEE Transactions on Geoscience and Remote Sensing, v. 32, n. 4, p. 779-785, 1994.

31 BALL, J. E.; BRUCE, L. M. Level set hyperspectral image classification using best band analysis. IEEE Transactions on Geoscience and Remote Sensing, v. 45, n. 10, p. 3022-3027, 2007.

32 BELLUCCI, J. P.; SMETEK, T. E.; BAUER, K. W. Improved hyperspectral image processing algorithm testing using synthetic imagery and factorial designed experiments. IEEE Transactions on Geoscience and Remote Sensing, v. 48, n. 3, p. 1211-1223, 2010.

33 BERNARD, K.; TARABALKA, Y.; ANGULO, J.; CHANUSSOT, J.; BENEDIKTSSON, J. A. Spectral-spatial classification of hyperspectral data based on a stochastic minimum spanning forest approach. IEEE Transactions on Image Processing, v. 21, n. 4, p. 2008-2021, 2012.

34 BUE, B. D.; MERENYI, E.; CSATHO, B. Automated labeling of materials in hyperspectral imagery. IEEE Transactions on Geoscience and Remote Sensing, v. 48, n. 11, p. 4059-4070, 2010.

35 BURGER, J.; GOWEN, A. Data handling in hyperspectral image analysis. Chemometricsand Intelligent Laboratory Systems, v. 108, n. 1, p. 13-22, 2011

36 BYUN, Y. G.; HAN, Y. K.; CHAE, T. B. A multispectral image segmentation approach for objectbased image classification of high resolution satellite imagery. KSCE Journal of Civil Engineering, v. 17, n. 2, p. 486-497, 2013.

37 CAMPS-VALLS, G.; BRUZZONE, L. Kernel-based methods for hyperspectral image classification. IEEE Transactions on Geoscience and Remote Sensing, v. 43, n. 6, p. 1351-1362, 2005.

38 CLARK, G. A.; SENGUPTA, S. K.; AIMONETTI, W. D.; ROESKE, F.; DONETTI, J. G. Multispectral image feature selection for land mine detection. IEEE Transactions on Geoscience and Remote Sensing, v. 38, n. 1, p. 304-311, 2000.

39 CUI, D.; ZHANG, Q.; LI, M.; HARTMAN, G. L.; ZHAO, Y. Image processing methods for quantitatively detecting soybean rust from multispectral images. Biosystems Engineering, v. 107, n. 3, p. 186-193, 2010.

40 DAMMER, K.-H.; MÖLLER, B.; RODEMANN, B.; HEPPNER, D. Detection of head blight (fusarium ssp.) in winter wheat by color and multispectral image analyses. Crop Protection, v.30 , n. 4, p. 420428, 2011.

$41 \mathrm{DI}, \mathrm{W}$; CRAWFORD, M. M. View generation for multiview maximum disagreement based active learning for hyperspectral image classification. IEEE Transactions on Geoscience and Remote Sensing, v. 50, n. 5, p. 1942-1954, 2012.

42 DOPIDO, I.; LI, J.; MARPU, P. R.; PLAZA, A.; DIAS, J. M. B.; BENEDIKTSSON, J. A. Semisupervised selflearning for hyperspectral image classification. IEEE Transactions on Geoscience and Remote Sensing, v. 51, n. 7, p. 4032-4044, 2013.

43 GORRETTA, N.; RABATEL, G.; FIORIO, C.; LELONG, C.; ROGER, J. An iterative hyperspectral image segmentation method using a cross analysis of spectral and spatial information. Chemometrics and Intelligent Laboratory Systems, v. 117, p. 213-223, 2012. doi:10.1016/j.chemolab.2012.05.004. 
44 HUANG, H.-Y.; KUO, B.-C. Double nearest proportion feature extraction for hyperspectral-image classification. IEEE Transactions on Geoscience and Remote Sensing, v. 48, n. 11, p. 4034-4046, 2010.

45 JENSEN, A. C.; BERGE, A.; ANNE SCHISTAD SOLBERG, MEMBER, I. Regression approaches to small sample inverse covariance matrix estimation for hyperspectral image classification. IEEE Transactions on Geoscience and Remote Sensing, v. 46, n. 10, p. 2814-2822, 2008.

46 KAWAGUCHI, S.; NISHII, R. Hyperspectral image classification by bootstrap adaboost with random decision stumps. IEEE Transactions on Geoscience and Remote Sensing, v. 45, n. 11, p. 3845-3851, 2007.

47 LAKOWICZ, J. R. Principles of fluorescence spectroscopy. 3rd ed. New York: Springer, 2006.

48 LEVADA, A. L.; MASCARENHAS, N. D.; TANNUS, A. A novel MAP-MRF approach for multispectral image contextual classification using combination of suboptimal iterative algorithms. Pattern Recognition Letters, v. 31, n. 13, p. 1795-1808, 2010.

$49 \mathrm{LI}, \mathrm{P}$.; XIAO, X. An unsupervised marker image generation method for watershed segmentation of multispectral imagery. Geosciences Journal, v. 8, n. 3, p. 325-331, 2004.

50 LIU, D.; SUN, D.-W.; ZENG, X.-A. Recent advances in wavelength selection techniques for hyperspectral image processing in the food industry. Food Bioprocess Technology, v. 7, n. 2, p. 307323, 2014.

51 LOPEZ, C.; PONS, M.; MORGENROTH, E. Evaluation of microscopic techniques (epifluorescence microscopy, CLSM, TPE-LSM) as a basis for the quantitative image analysis of activated sludge. Water Research, v. 39, n. 2-3, p. 456-468, 2005.

52 MA, L.; CRAWFORD, M. M.; TIAN, J. Local manifold learning-based k-nearest-neighbor for hyperspectral image classification. IEEE Transactions on Geoscience and Remote Sensing, v. 48, n. 11, p. 4099-4109, 2010.

53 IEC TECHNICAL COMMITTEE. Technical committee no. 100: audio, video and multimedia systems and equipment. 1998. Technical report.

54 MITRA, P.; SHANKAR, B. U.; PAL, S. K. Segmentation of multispectral remote sensing images using active support vector machines. Pattern Recognition Letters, v. 25, n. 9, p. 1067-1074, 2004.

55 PARK, J.; KIHM, K. Use of confocal laser scanning microscopy (CLSM) for depth wise resolved microscale-particle image velocimetry ( $\mu$-PIV). Optics and Lasers in Engineering, v. 44, n.3-4, p. 208223, 2006.

56 PAVIOTTI, A.; RATTI, F.; POLETTO, L.; CORTELAZZO, G. M. Multispectral acquisition of large-sized pictorial surfaces. EURASIP Journal on Image and Video Processing, v. 2009, p. 793-756, 2009. doi:10.1155/2009/793756.

57 PLAZA, A.; BENEDIKTSSON, J. A.; BOARDMAN, J. W.; BRAZILE, J.; BRUZZONE, L.; CAMPS-VALLS, G.; CHANUSSOT, J.; FAUVEL, M.; GAMBA, P.; GUALTIERI, A.; MARCONCINI, M.; TILTON, J. C.; TRIANNI, G. Recent advances in techniques for hyperspectral image processing. Remote Sensing of Environment, v. 113, p. S110-S122, 2009. Supplement 1. doi:10.1016/j.rse.2007.07.028 
58 PUYEN, Z. M.; VILLAGRASA, E.; MALDONADO, J.; ESTEVE, I.; SOLÉ, A. Viability and biomass of micrococcus luteus DE 2008 at different salinity concentrations determined by specific fluorochromes and CLSM-image analysis. Current Microbiology, v. 64, n. 1, p. 75-80, 2012.

59 ROBILA, S. A. Using spectral distances for speedup in hyperspectral image processing. International Journal of Remote Sensing, v. 26, n. 24, p. 5629-5650, 2005.

60 ROSS, B. J.; GUALTIERI, A. G.; FUETEN, F.; BUDKEWITSCH, P. Hyperspectral image analysis using genetic programming. Applied Soft Computing, v. 5, n. 2, p. 147-156, 2005.

61 SCHUSTER, S.; BERNEWITZ, R.; GUTHAUSEN, G.; ZAPP, J.; GREINER, A. M.; K OHLER, K.; SCHUCHMANN, H. P. Analysis of w 1 /o/w 2 double emulsions with CLSM: statistical image processing for droplet size distribution. Chemical Engineering Science, n. 81, n. 1, p. 84-90, 2012.

$62 \mathrm{SHI}$, Z.; ANDERSON, C. A. 2-D image localization in hyperspectral image analysis of pharmaceutical materials. Journal of Pharmaceutical Innovation, v. 6, n. 1, p. 2-9, 2010.

63 SOLÉ, A.; MAS, J.; ESTEVE, I. A new method based on image analysis for determining cyanobacterial biomass by CLSM in stratified benthic sediments. Ultramicroscopy, v. 107, n. 8, p. 669673, 2007.

64 SUN, C.; FIKSDAL, L.; HANSSEN-BAUER, A.; RYE, M. B.; LEIKNES, T. Characterization of membrane biofouling at different operating conditions (UX) in drinking water treatment using confocal laser scanning microscopy (CLSM) and image analysis. Journal of Membrane Science, v. 382, p. 194-201, 2011.

65 TARABALKA, Y.; BENEDIKTSSON, J. A.; CHANUSSOT, J.; TILTON, J. C. Multiple spectral-spatial classification approach for hyperspectral data. IEEE Transactions on Geoscience and Remote Sensing, v. 48, n. 11, p. 4122-4132, 2010.

66 VELASCO-FORERO, S.; ANGULO, J. Supervised ordering in : application to morphological processing of hyperspectral images. IEEE Transactions on Image Processing, v. 20, n. 11, p. 3301-3308, 2011.

67 VIDAL, M.; AMIGO, J. M. Pre-processing of hyperspectral images. essential steps before image analysis. Chemometrics and Intelligent Laboratory Systems, v. 117, p. 138-148, 2012. doi:10.1016/j.chemolab.2012.05.009.

68 WELS, M.; HUBER, M.; HORNEGGER, J. Fully automated segmentation of multiple sclerosis lesions in multispectral MRI. Pattern Recognition and Image Analysis, v. 18, n. 2, p. 347-350, 2008.

69 YANG, C.-C.; CHAO, K.; CHEN, Y.-R. Development of multispectral image processing algorithms for identification of wholesome, septicemic, and in ammatory process chickens. Journal of Food Engineering, v. 69, n. 2, p. 225-234, 2005.

70 YANG, J.-M.; YU, P.-T.; KUO, B.-C. A nonparametric feature extraction and its application to nearest neighbor classification for hyperspectral image data. IEEE Transactions on Geoscience and Remote Sensing, v. 48, n. 3, p. 1279-1293, 2010.

71 COletTA, V. C.; REZENDE, C. A.; CONCEIÇÃO, F. R. da; POLIKARPOV, I.; GUIMARÃES, F. E. G. Mapping the lignin distribution in pretreated sugarcane bagasse by confocal and fluorescence 
lifetime imaging microscopy. Biotechnology for Biofuels, v. 6, n. 43, p. 1-10, 2013. Disponível em: <http://www.biotechnologyforbiofuels.com/content/6/1/43>. Acesso em: 10 set 2014.

72 ESPÍRITO SANTO, M. Otimização de estratégias de pré-tratamento de bagaço de cana-de-açúcar para a produção de etanol de segunda geração via hidrólise enzimática. 2015. 95p. Dissertação (Mestrado em Ciências) - Instituto de Física de São Carlos, Universidade de São Paulo, São Carlos, 2015.

73 ACHYUTHAN, K. E.; ACHYUTHAN A. M; ADAMS P. D.; DIRK S. M.; HARPER J. C.; SIMMONS B. A.; SINGH A. K. Supramolecular self-assembled chaos: polyphenolic lignin's barrier to cost-effective lignocellulosic biofuels. Molecules, v. 15, p. 8641-8688, 2010.

74 MIQUEL, F. A. W. Flora brasiliensis, 1853. v. 4, part 1, n. 12 prancha 66. Disponível em: <http://florabrasiliensis.cria.org.br/opus?vol=4\&part=1>. Acesso em: 9 julho 2015.

75 ONODA, Y.; SCHIEVING F.; ANTEN N. P. R. A novel method of measuring leaf epidermis and mesophyll stiffness shows the ubiquitous nature of the sandwich structure of leaf laminas in broadleaved angiosperm species. Journal of Experimental Botany, v. 66 n. 9 p.2487-2499, 2015. Disponível em: <http://jxb.oxfordjournals.org/content/66/9/2487.full.pdf+html>. Acesso em: 15 julho 2015.

76 CARLQUIST, S. Leaf Anatomy and ontogeny in Argyroxiphium and Wilkesia (Compositae).

American Journal of Botany, v.44, n.8 p.696-705, 1957. Disponível em:

<http://woodevolution.org/pdf/Leaf-Anatomy-and-Ontogeny-in 1957.pdf>. Acesso em: 25 mai 2015.

77 ROBERTS, A. LEAF initiation in Coleus. 1998. Disponível em:

<http://www.uri.edu/cels/bio/plant anatomy/15.html >. Acesso em: 25 julho 2015.

78 BARP, E. A.; SOARES, G. L. G.; GOSMANN, G.; MACHADO, A. M.; VECCHI, C.V.; MOREIRA, G. R. P. Phenotypic plasticity in Passiflora suberosa L. (Passifloraceae): induction and reversion of two morphs by variation in light intensity.Brazilian Journal of Biology. v.66, n.3, p.853-862, 2006. Disponível em: <http://www.scielo.br/pdf/bjb/v66n3/10.pdf>. Acesso em: 20 julho 2014.

79 LSCM typical system. Disponível em:

<http://www.udel.edu/biology/Wags/histopage/illuspage/lec1/lscm.jpg $>$. Acesso em: 25 jul 2014.

80 CONFOCAL microscope scanning systems. Microscopy resource center. Disponível em: <http://olympus.magnet.fsu.edu/primer/techniques/confocal/confocalscanningsystems.html>.

Acesso em: 13 nov 2014.

81 LASER focus world. Photonics tecnologies \& Solutions for technical trofessionals worldwide. Disponível em: <http://www.laserfocusworld.com/content/dam//fw/print-articles/2014/11/1411LFWnewsf3web.jpg $>$.

Acesso em: 18 dez 2015.

82 BENTHAM, G. Flora brasiliensis, 1862. v. 15, part 1, fasc. 29, prancha 67. Disponível em: <http://florabrasiliensis.cria.org.br/opus?vol=15\&part=1>. Acesso em: 9 julho 2015.

83 VON ESENBECK, C. G. D. N. Flora brasiliensis. 1845. v. 2, part 1, fasc. 3, prancha 26. Disponível em: <http://florabrasiliensis.cria.org.br/opus?vol=2\&part=1>. Acesso em: 9 julho 2015.

84 MIQUEL, F. A. W. Flora brasiliensis. 1853. v. 4, part 1, fasc. 12, prancha 57. Disponível em: <http://florabrasiliensis.cria.org.br/opus?vol=4\&part=1>. Acesso em: 9 julho 2015. 
85 RESONANT scanning in laser confocal microscopy. Disponível em:

$<$ http://www.microscopyu.com/articles/confocal/resonantscanning.html>. Acesso em: Acesso em: 18 dez 2015.

86 PHOTOMULTIPLIER tubes. Disponível em:

$<$ http://micro.magnet.fsu.edu/primer/digitalimaging/concepts/photomultipliers.html $>$. Acesso em: 18 dez 2015.

87 LINEAR array multianode photomultiplier for spectral imaging confocal microscopy. Disponível em: $\quad<$ http://www.zeiss.com/microscopy/en us/solutions/reference/spectral-imaging/practicalaspects-of-spectral-imaging.html>. Acesso em: 16 jan 2015.

88 DE OLIVEIRA, M. Entre açúcares e genes. Revista FAPESP, v. 200, p. 86-91, 2012.

89 GUIA geográfico. Disponível em: <http://www.mapas-brasil.com/>. Acesso em: 20 ago 2015.

90 CESAR, A. T.; SOlLERO, P. A.; PEREIRA, C.; SOLLERO, G. Jacaranda caroba, medicamento de Mure. Cultura Homeopática. v. 3, n. 6, p. 6-7, 2004. 